\title{
Data on Ground-Water Quality in the Winnemucca District of the U.S. Bureau of Land Management, Northwestern Nevada, 1934-87
}

By Kerry T. Garcia and Judy M. Jacoboni

U.S. GEOLOGICAL SURVEY

Open-File Report 89-424

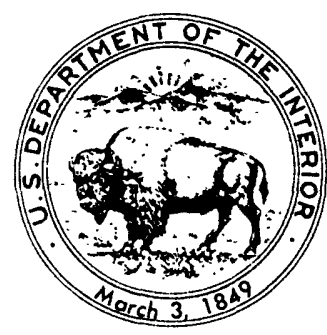

Carson City, Nevada 1991 


\title{
DEPARTMENT OF THE INTERIOR
}

MANUEL LUJAN, JR., Secretary

\author{
U.S. GEOLOGICAL SURVEY
}

Dallas L. Peck, Director

Any use of trade, product, or firm names in this publication is for descriptive purposes only and does not constitute endorsement by the U.S. Government.

For additional information write to:

U.S. Geological Survey

Room 227, Federal Building

705 North Plaza Street

Carson City, NV 89701
Copies of this report may be purchased from:

U.S. Geological Survey

Books and Open-File Reports Section

Federal Center, Building 810

Box 25425

Denver, CO 80225 


\section{CONTENTS}

Page

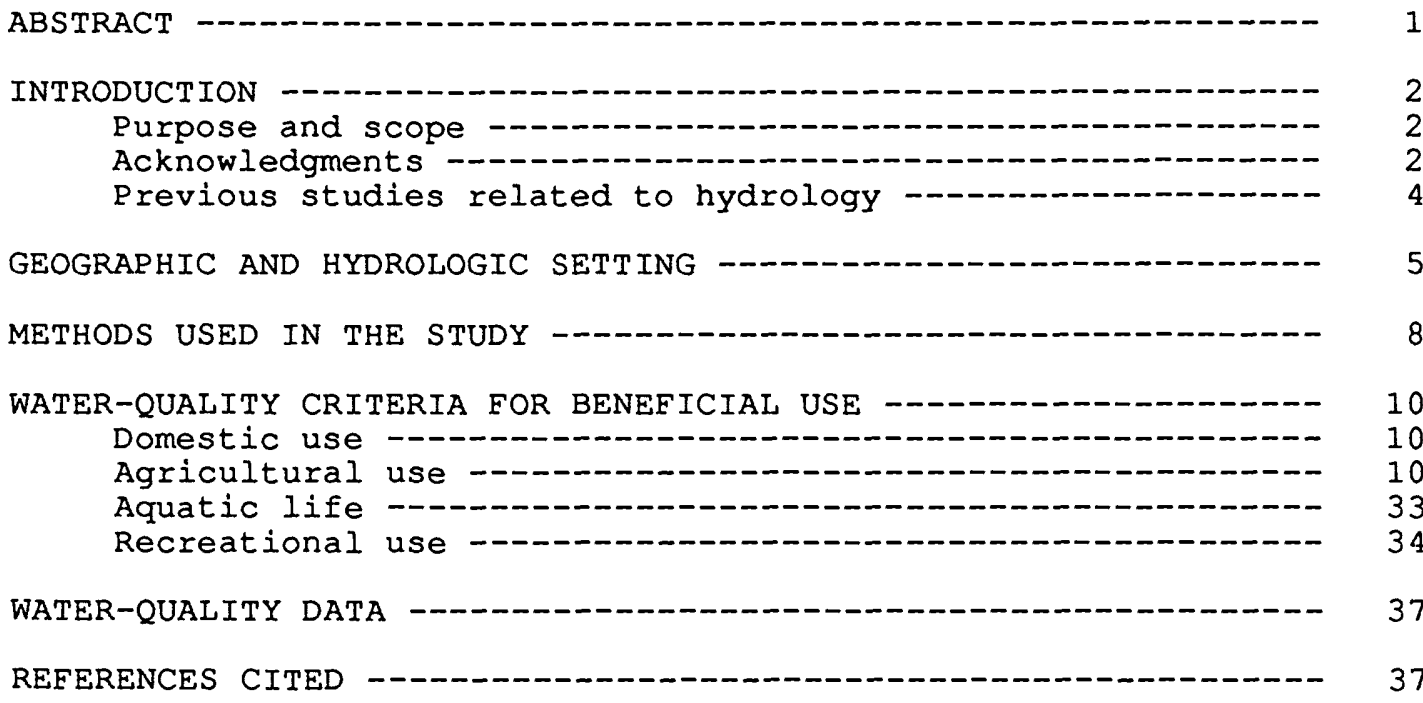

IILUSTRATIONS

[Plate in pocket at back of report]

Plate 1. Wells and springs for which water-quality data are listed in this report

Figures 1-2. Maps showing:

1. Location of study area and sites where precipitation data were collected by

National Weather Service - 3

2. Hydrographic regions and areas in the

Winnemucca District

3-5. Maps showing sites where primary

drinking-water standards have been exceeded for:

3. Fluoride -

4. Arsenic, barium, and cadmium - 29

5. Lead, mercury, and nitrate 30 
TABLES

Page

Table 1. Background information on constituents and properties of water - 11

2. Sites where primary drinking-water standards

for selected constituents were exceeded -.--------- 26

3. Recommended criteria for dissolved constituents and properties of water used for agriculture -...- 31

4. Relative tolerance of selected plants to boron -..-- 33

5. Recommended criteria for aquatic life for selected constituents and properties of water used for aquatic habitat - 35

6. Water-quality data and other information for wells and springs -.-.- 41

7. Maximum, minimum, and median values for selected constituents and properties of water from wells and springs - 148

8. Stable isotope data for selected wells and springs - 150

CONVERSION FACTORS AND ABBREVIATIONS

Multiply

foot $(f t)$

inch (in.)

mile (mi)
By

0.3048

25.40

1.609

2.590

To obtain

Degrees Fahrenheit $\left({ }^{\circ} \mathrm{F}\right)$ can be converted to degrees celsius $\left({ }^{\circ} \mathrm{C}\right)$ by using the formula ${ }^{\circ} \mathrm{C}=0.5556\left({ }^{\circ} \mathrm{F}-32\right)$.

\section{SEA LEVEL}

In this report, "sea level" refers to the National Geodetic Vertical Datum of 1929 (NGVD of 1929, formerly called "Sea-Level Datum of 1929"), which is derived from a general adjustment of the firstorder leveling networks of both the United States and Canada. 


\title{
Data on Ground-Water Quality in the Winnemucca District of the U.S. Bureau of Land Management, Northwestern Nevada, 1934-87
}

\author{
By Kerry T. Garcia and Judy M. Jacoboni
}

\begin{abstract}
This report is a compilation of data on the quality of ground water in the Winnemucca District of the U.S. Bureau of Land Management. It includes data on 591 samples collected from 530 wells and springs from 1934 to 1987 .

The water-quality data in this report include specific conductance, $\mathrm{pH}$, water temperature, color, turbidity, hardness, cations (calcium, magnesium, sodium, potassium), alkalinity, anions (carbonate, bicarbonate, sulfate, chloride, fluoride), silica, dissolved solids, nitrate, ammonia, and phosphorus. In addition, some analyses include the trace constituents aluminum, antimony, arsenic, barium, beryllium, bismuth, boron, cadmium, chromium, cobalt, copper, iron, lead, lithium, manganese, mercury, molybdenum, nickel, selenium, silver, strontium, tin, vanadium, and zinc. Data for hydroxide, sulfide, bromide, iodide, nitrite, cesium, gallium, germanium, rubidium, titanium, zirconium, tritium, deuterium, oxygen-18, carbon-13, and the gases argon, carbon dioxide, ethane, hydrogen, methane, and oxygen for a limited number of sites are also included. Limited data for radionuclides, stable isotopes, and organics also are listed. Some samples exceeded primary drinking water standards for fluoride, trace constituents, and nitrates.
\end{abstract}




\section{INTRODUCTION}

The Winnemucca District of the U.S. Bureau of Land Management (BLM) encompasses about 13,000 square miles in northwestern Nevada (figure 1). Several small streams, including the Humboldt, Little Humboldt, Kings, and Quinn Rivers, and many springs and wells are in the District.

The BLM is responsible for the management of large tracts of public land in Nevada. Baseline data on the quality of ground water on those lands are necessary for development and execution of plans for land management and watershed protection, and for development and protection of domestic and livestock water supplies. Because of this need, the U.S. Geological Survey (USGS), in cooperation with the BLM, began a two-phase study within the Winnemucca District.

\section{Purpose and Scope}

This report presents the results of the first phase of the study. The purpose of the first phase was to compile a data base of the quality of the ground-water resources from existing information about water quality in the Winnemucca District. The scope of the work included an inventory and compilation of existing information and publication of the data. Previously published reports were the source of much of the water-quality data.

Phase two, as planned, will study the adequacy of data that were compiled and inventoried in phase one to address the suitability of the ground water for beneficial uses. Phase two also may include initiation of a monitoring program designed to meet shortcomings in the present data base.

\section{Acknowledgments}

The authors are grateful for the assistance provided by personnel of the BLM and the Nevada Department of Human Resources, Bureau of Consumer Health Protection Service (NBCHPS). Some of the water-quality data were provided by NBCHPS. 


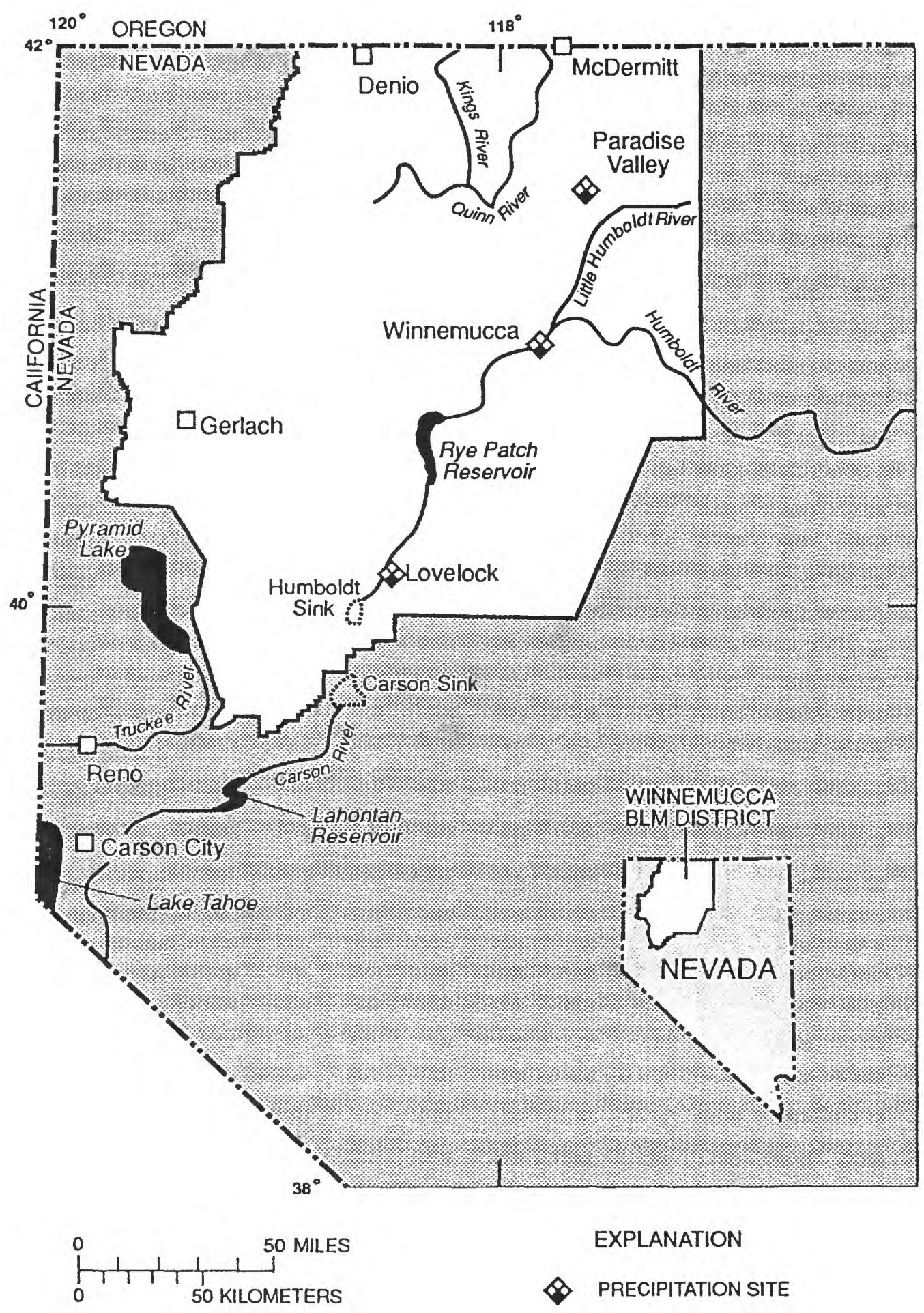

FIGURE 1.--Location of study area and sites where precipitation data were collected by National Weather Service. 


\section{Previous Studies Related to Hydrology}

Several hydrologic studies of selected areas in and around the Winnemucca District have been made. Most of the studies were reconnaissance investigations; they include brief descriptions of the geology, hydrology, and water quality. The reports are as follows:

$\begin{array}{ll}\text { Hydrographic } \\ \begin{array}{l}\text { Report } \\ \text { number }\end{array} & \begin{array}{r}\text { areas discussed } \\ \text { (see figure 2) }\end{array}\end{array} \quad \begin{array}{r}\text { Authors and year of publication } \\ \text { (see "References Cited") }\end{array}$

Nevada Division of Water Resources Reconnaissance Reports

$\begin{array}{rll}4 & 29 & \text { Sinclair, 1962a } \\ 5 & 72 & \text { Eakin, 1962 } \\ 7 & 31 & \text { Sinclair, 1962b } \\ 11 & 24 & \text { Sinclair, 1962 c } \\ 20 & 23,24,25,26,27,28 & \text { Sinclair, 1963a } \\ 22 & 1,2,3,4 & \text { Sinclair, 1963b } \\ 23 & 124,125,126,127,128, & \text { Cohen and Everett, 1963 } \\ 29 & 130,132 & \text { Cohen, 1964 } \\ 32 & 71 & \text { Everett and Rush, 1965 } \\ 44 & 73 & \text { Glancy and Rush, 1968 } \\ 55 & 17,18,19,20,21,22,98 & \text { Harrili, 1970 } \\ 57 & 75,77,78,79 & \text { Van Denburgh and others, } 1973\end{array}$

Nevada Division of Water Resources Bulletins

$\begin{array}{lll}10 & 69 & \text { Loeltz and others, } 1949 \\ 13 & 129 & \text { Loeltz and Phoenix, } 1955 \\ 14 & 33 & \text { Visher, } 1957 \\ 19 & 70 & \text { Cohen, } 1962 \\ 24 & 70 & \text { Cohen, 1963 } \\ 31 & 30 & \text { Malmberg and Worts, } 1966 \\ 34 & 33 & \text { Huxel, 1966 } \\ 37 & 24 & \text { Harrill, 1969 } \\ 39 & 69 & \text { Harrill and Moore, } 1970\end{array}$

U.S. Geological Survey Open-File Reports

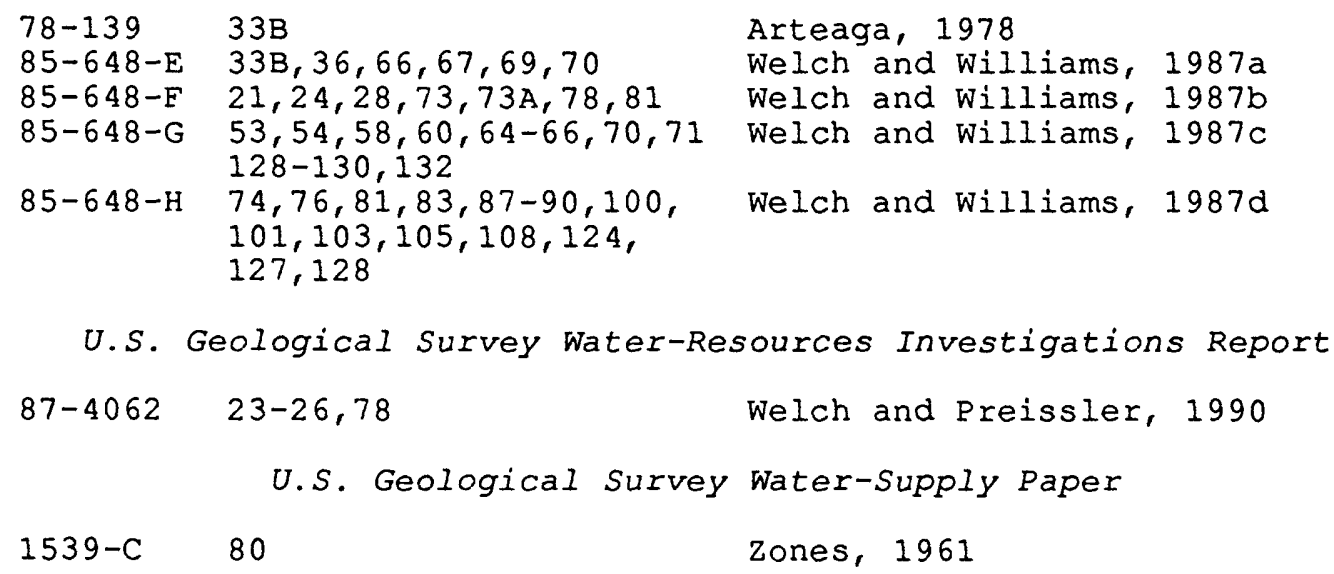

U.S. Geological Survey Water-Resources Investigations Report 87-4062 23-26,78 Welch and Preissler, 1990 U.S. Geological Survey Water-Supply Paper

1539-C $80 \quad$ Zones, 1961 


\section{GEOGRAPHIC AND HYDROLOGIC SETTING}

The Winnemucca District in northwestern Nevada includes part or all of 47 hydrographic areas (Rush, 1968) in Nevada (figure 2). The District lies almost entirely within the Great Basin, and is characterized by a series of generally north-south-trending mountains and valleys. The mountains form the topographic and drainage divides between the hydrographic areas and can impede ground-water movement between adjacent valleys. Much of the Winnemucca District is high desert, with altitudes ranging from about 4,000 to 9,800 feet above sea level.

The Humboldt River is the major stream in the area, flowing through and terminating in the Winnemucca District (figure 1). The stream begins in eastern Nevada and flows southwestward and westward before entering the eastern part of the study area. The stream then flows northwestward for about 50 miles before turning southwestward again and flowing into Rye Patch Reservoir. The natural terminus of the stream is the Humboldt Sink, south of Lovelock.

Water released from Rye Patch Reservoir is used primarily for irrigation in the Lovelock area. The water that flows into the Humboldt Sink is mostly excess irrigation and wastewater from the Lovelock area.

The Little Humboldt River and its tributaries lie mostly in the winnemucca District. Flow from this stream is diverted and used for irrigation in Paradise Valley. Excess irrigation and wastewater that does not evaporate or percolate, and is not transpired, flows into the Humboldt River near Winnemucca.

Kings River is a small stream in the northern part of the District that is a tributary of the Quinn River. Several other small streams lie within the District and generally terminate on the valley floors.

The Winnemucca District encompasses all or parts of Churchill, Humboldt, Lyon, Pershing, and Washoe Counties, with Humboldt (population, about 12,000 ) and Pershing (population, about 4,400) Counties comprising most of the District. The Winnemucca District has two major population centers, Winnemucca (population, about 6,000) and Lovelock (population, about 2,200), which provide most of the services required by people in the District (J.P. Comeaux, Nevada Department of Taxation, written commun., 1987). Smaller rural communities and ranches also are in the area.

The Sierra Nevada range along the western Nevada border and air masses moving eastward from the Pacific Ocean are important factors that control the climate in the study area. As the air masses move over the Sierra Nevada, the air cools and much of the moisture condenses and precipitates in the mountains. Consequently, the project area has a subhumid climate in the mountains and an arid to semiarid climate in the valleys. 


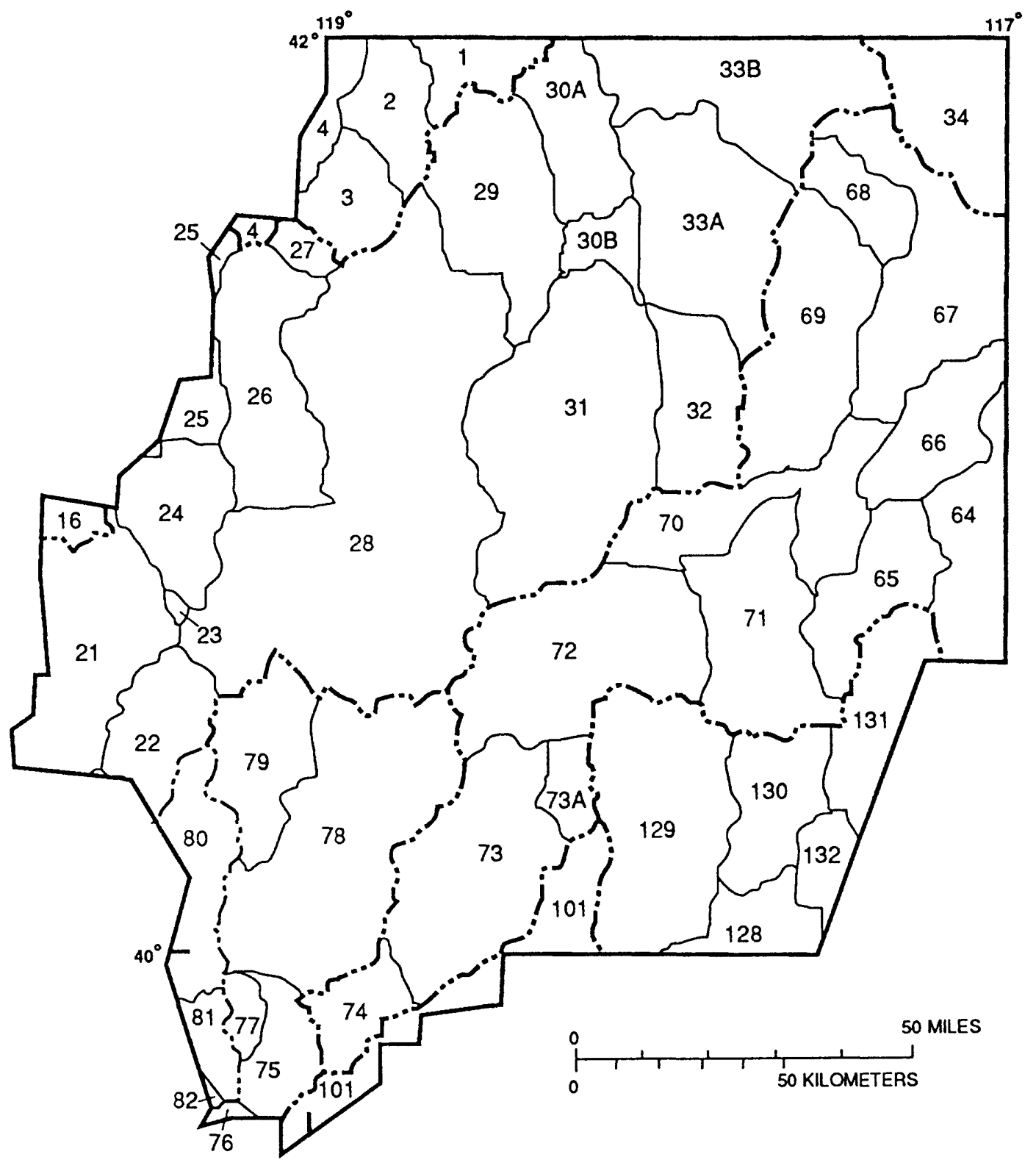

EXPLANATION

$-\cdots-$ BOUNDARY OF HYDROGRAPHIC REGION
- BOUNDARY OF HYDROGRAPHIC AREA

FIGURE 2.--Hydrographic regions and areas (Rush, 1968) in the Winnemucca District. 
HYDROGRAPHIC REGIONS AND AREAS

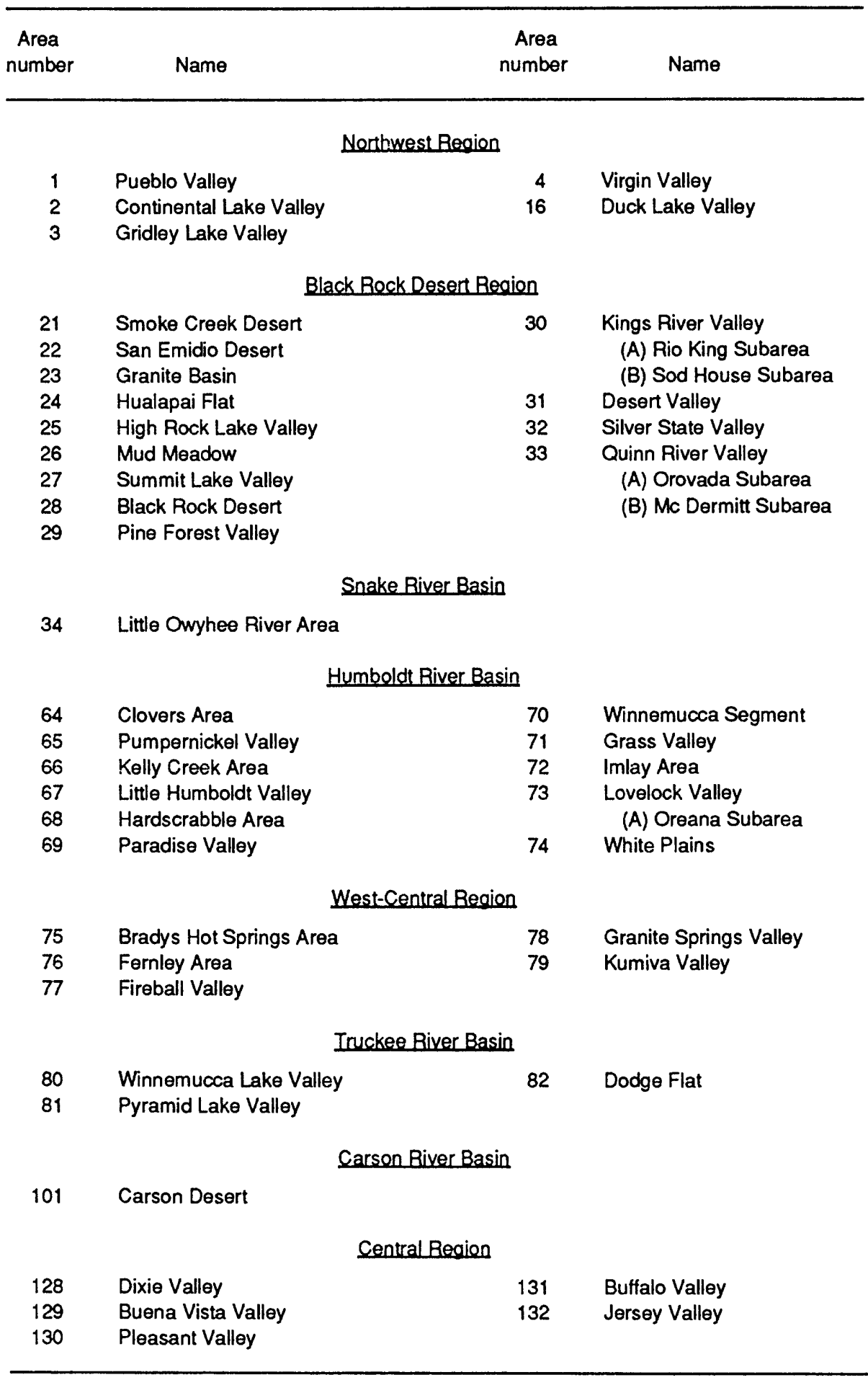

FIGURE 2.--Continued. 
Average annual precipitation (National Climatic Center, 1987) at three weather stations in the study area (figure 1) is:

\begin{tabular}{lcc}
\hline Station name & $\begin{array}{c}\text { Altitude } \\
\text { (feet above } \\
\text { sea level) }\end{array}$ & $\begin{array}{c}\text { Average annual } \\
\text { precipitation } \\
\text { (inches) }\end{array}$ \\
\hline Lovelock & 3,975 & 5.5 \\
Paradise valley & 4,675 & 9.2 \\
Winnemucca & 4,297 & 7.9 \\
\hline
\end{tabular}

Generally, most of the precipitation falls in the winter as snow. In the summer, precipitation is generally rain from thunderstorms.

Air temperature in the study area can fluctuate as much as $50^{\circ} \mathrm{F}$ in a 24-hour period during the summer and as much as $30^{\circ} \mathrm{F}$ in the winter. The mean annual air temperature at winnemucca is about $49{ }^{\circ} \mathrm{F}$. The average monthly temperature in January is about $30{ }^{\circ} \mathrm{F}$, whereas in July it is about $72{ }^{\circ} \mathrm{F}$. However, temperatures as low as $-36^{\circ} \mathrm{F}$ and as high as $108^{\circ} \mathrm{F}$ have been recorded in winnemucca.

\section{METHODS USED IN THE STUDY}

Data on ground-water quality in the Winnemucca District were extracted from a statewide data base maintained by the USGS. The data base included information on 591 water samples collected from 530 wells and springs from 1934 to 1987 . Most of the samples reported in the data base were analyzed for specific conductance, $\mathrm{pH}$, temperature, color, turbidity, hardness, cations (calcium, magnesium, sodium, and potassium), alkalinity, anions (carbonate, bicarbonate, sulfate, 1 chloride, and fluoride), silica, dissolved solids, nitrate, ammonia, and phosphorus. In addition, about 30 percent of the samples were analyzed for at least some of the following trace constituents: aluminum, antimony, arsenic, barium, beryllium, bismuth, boron, cadmium, chromium, cobalt, copper, iron, lead, lithium, manganese, mercury, molybdenum, nickel, selenium, silver, strontium, tin, vanadium, and zinc. Data for hydroxide, sulfide, bromide, iodide, nitrite, cesium, gallium, germanium, rubidium, titanium, zirconium, tritium, deuterium, oxygen-18, carbon-13, and the gases argon, carbon dioxide, ethane, hydrogen, methane, and oxygen for a limited number of sites are also included. Limited data for radionuclides, stable isotopes, and organics also are listed.

1 Ammonia data are the result of an analytical procedure that determines the combined concentration of the ammonium ion ( $\mathrm{NH}_{4}^{+}$) plus un-ionized ammonia $\left(\mathrm{NH}_{3}\right)$. In most waters having a $\mathrm{pH}$ of less than about 8.5 , the concentration of ammonium exceeds that of ammonia. 
Verification of site locations and analytical results was not within the scope of this project. However, as a check on the accuracy of the chemical analyses, the electrical balance between the cations and anions was compared. If the difference between the sum of the major cations and the sum of the major anions, expressed in milliequivalents per liter, exceeded 10 percent, the analysis was considered inaccurate and was excluded from the data compilation. When the electrical imbalance was small, the accuracy of the analytical results was considered acceptable. The imbalance calculation is:

$$
\text { Imbalance }\left(\text { in percent) }=\frac{\text { (cations - anions) }}{\text { (cations + anions) }} \times 100\right.
$$

This check, which can be made only if all major ions have been analyzed and reported, could be made on about 40 percent of the analyses. Of those, 18 out of 228 had an imbalance that exceeded 10 percent and were eliminated from the data compilation.

Some of the reconnaissance reports (p. 4) include data that had not been stored in the water-quality data base. For the sites in these reports with water-quality data, well and spring locations were retrieved from the USGS site file, the location information was matched with the sites in these reports, and the data were then entered into the data base.

A few analyses from the NBCHPS were also entered into the water-quality data base if a site location could be matched with the analysis.

The analytical methods in use, their accuracy, precision, and detection limits, and the laboratory performing the analyses must be considered when interpreting water-quality data from extended time periods. Differences in sampling and sample handling must also be taken into account. Changes in sampling procedures and analytical techniques can have a significant effect on water-quality data. Geological Survey Water-supply Paper 1454 and the first, second, and third editions of Book 5, Chapter A1, Techniques of Water-Resources Investigations of the United States Geological Survey can be consulted for information about USGS methods from 1960 to the present. 
With modern technology and treatment, almost any ground water can be treated to meet drinking-water standards; however, the costs involved can be prohibitive. To be suitable for domestic use, ground water is generally expected to meet drinking-water standards with little or no treatment. Constituents in ground water may exceed a standard without injury to health; the concentration and duration depends on the nature of the constituent (National Academy of Sciences and National Academy of Engineering, 1973, p. 51).

Drinking-water standards for many constituents have been adopted by the State of Nevada. Those standards--as well as Federal standards-and the sources and significance of selected water-quality constituents, are listed in table 1. Nevada public-supply standards do not apply to individual private water supplies; however, they are used as recommended maximum concentrations (Darrell Rasner, NBCHPS, oral commun., 1986). Sites in the Winnemucca District where primary drinking-water standards were exceeded are listed in table 2 and shown in figures $3-5$.

\section{Agricultural Use}

High concentrations of some constituents are toxic to animals or may accumulate in their tissues and body fluids, making them unsafe for human consumption (National Academy of Sciences and National Academy of Engineering, 1973, p. 309). Concentrations of constituents that make a water undesirable for livestock depend on several variables, such as age, sex, species, physiological state, water intake, and diet of the animal; the oxidation state of the toxic constituents; and the temperature of the environment (National Academy of Sciences and National Academy of Engineering, p. 309).

The criteria generally used to determine if a water is suitable for irrigation are (1) dissolved solids concentration (salinity hazard), (2) proportion of sodium to calcium plus magnesium (alkali hazard), and (3) boron concentration (toxicity hazard). Specific conductance is an indication of the salinity hazard because of its relation to dissolved solids. Dissolved-solids concentration can be estimated by multiplying specific-conductance values by a factor generally ranging from 0.55 to 0.75 (Hem, 1985, p. 67).

The alkali hazard is related to specific conductance and the SAR (sodium adsorption ratio). SAR is defined as follows:

$(\mathrm{Na})$

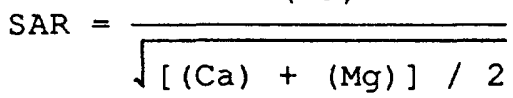

where (Na), (Ca), and ( $\mathrm{Mg}$ ) are the concentrations of sodium, calcium, and magnesium, respectively, expressed in milliequivalents per liter (U.S. Salinity Laboratory Staff, 1954).

Table 3 lists the recommended concentrations for selected constituents in water for agricultural use; table 4 classifies selected plants as to their relative tolerance to boron; and table 7 (back of report) shows ranges in values for selected constituents and properties of water from wells and springs in the study area. 


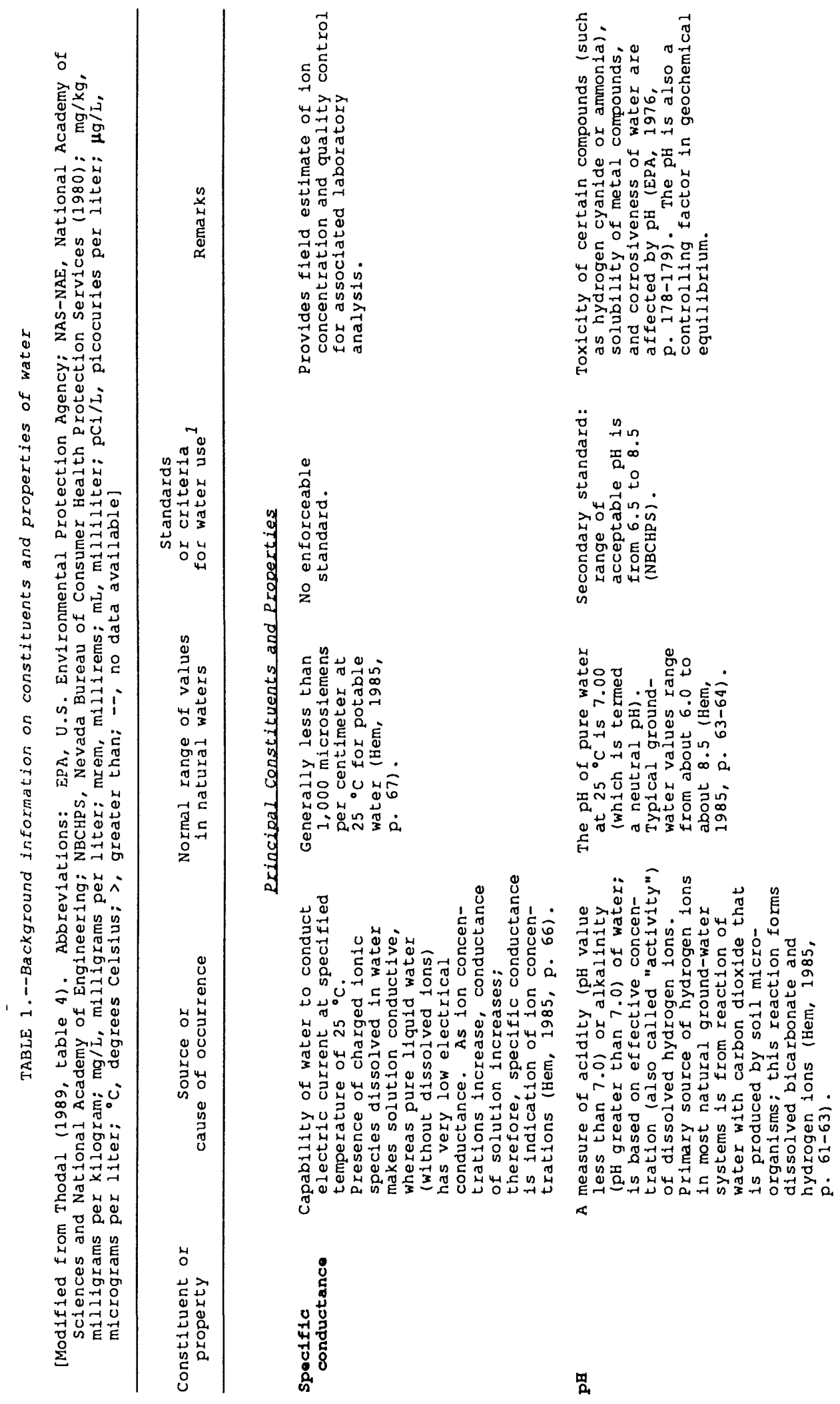




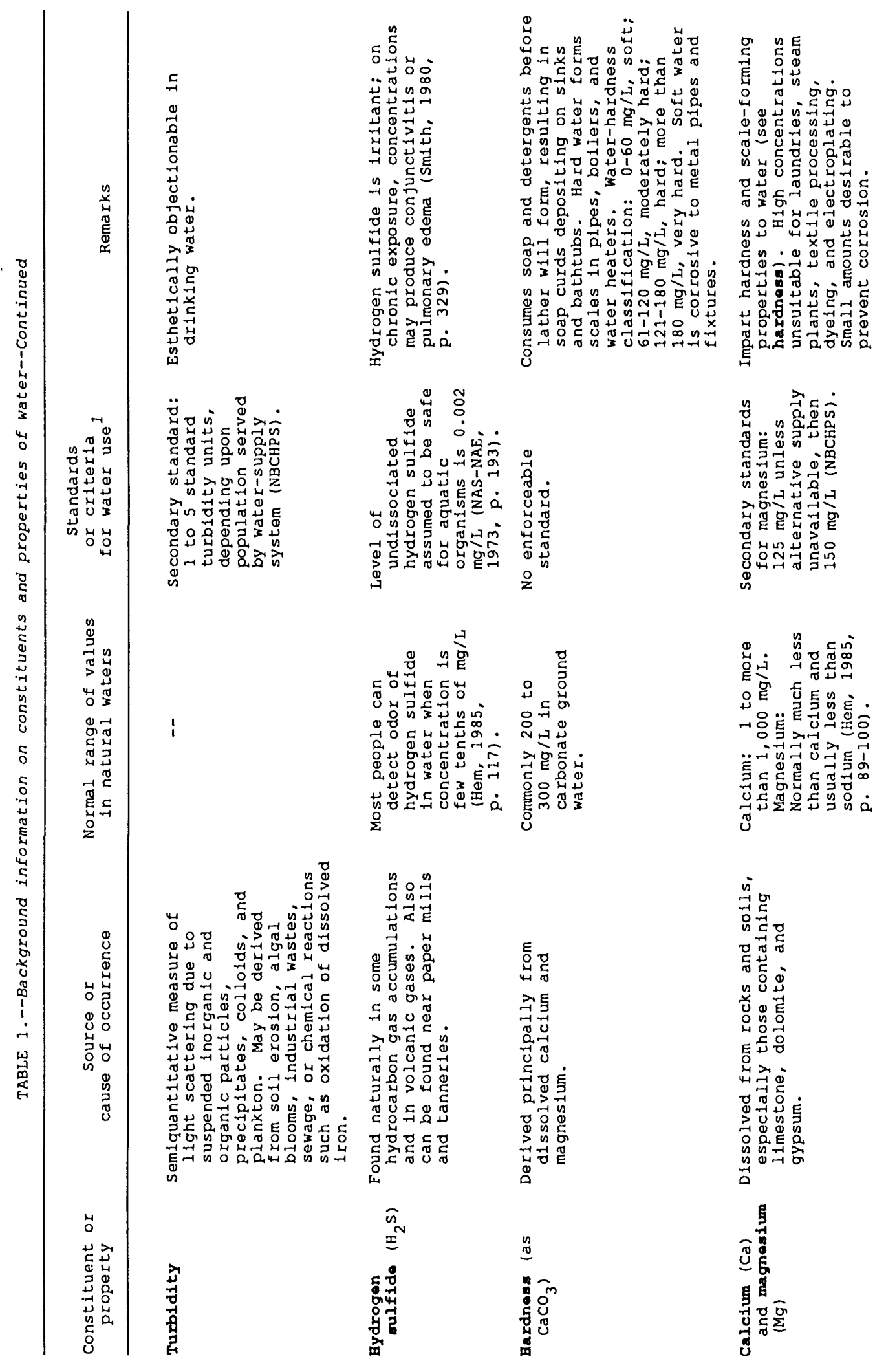




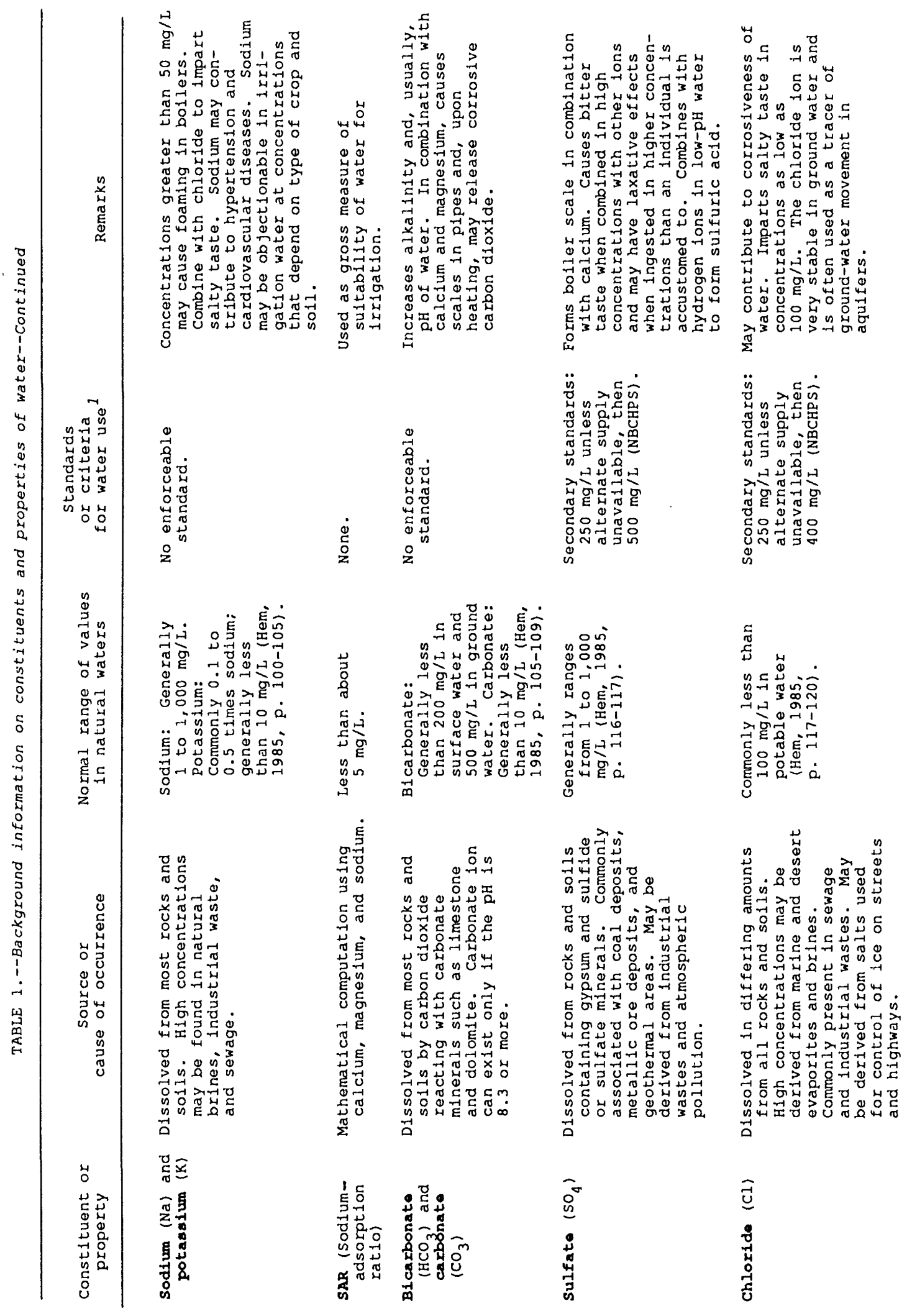




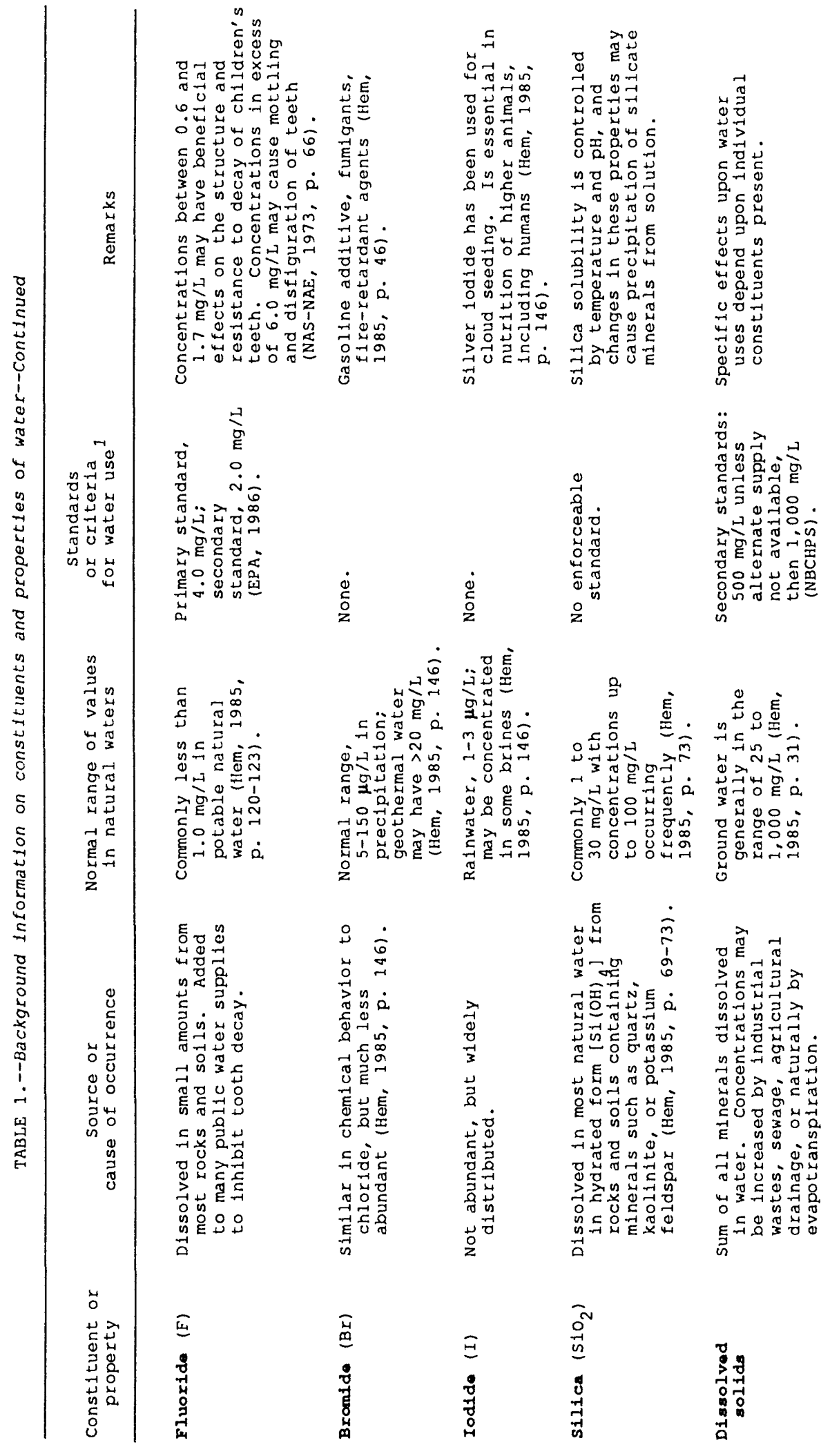




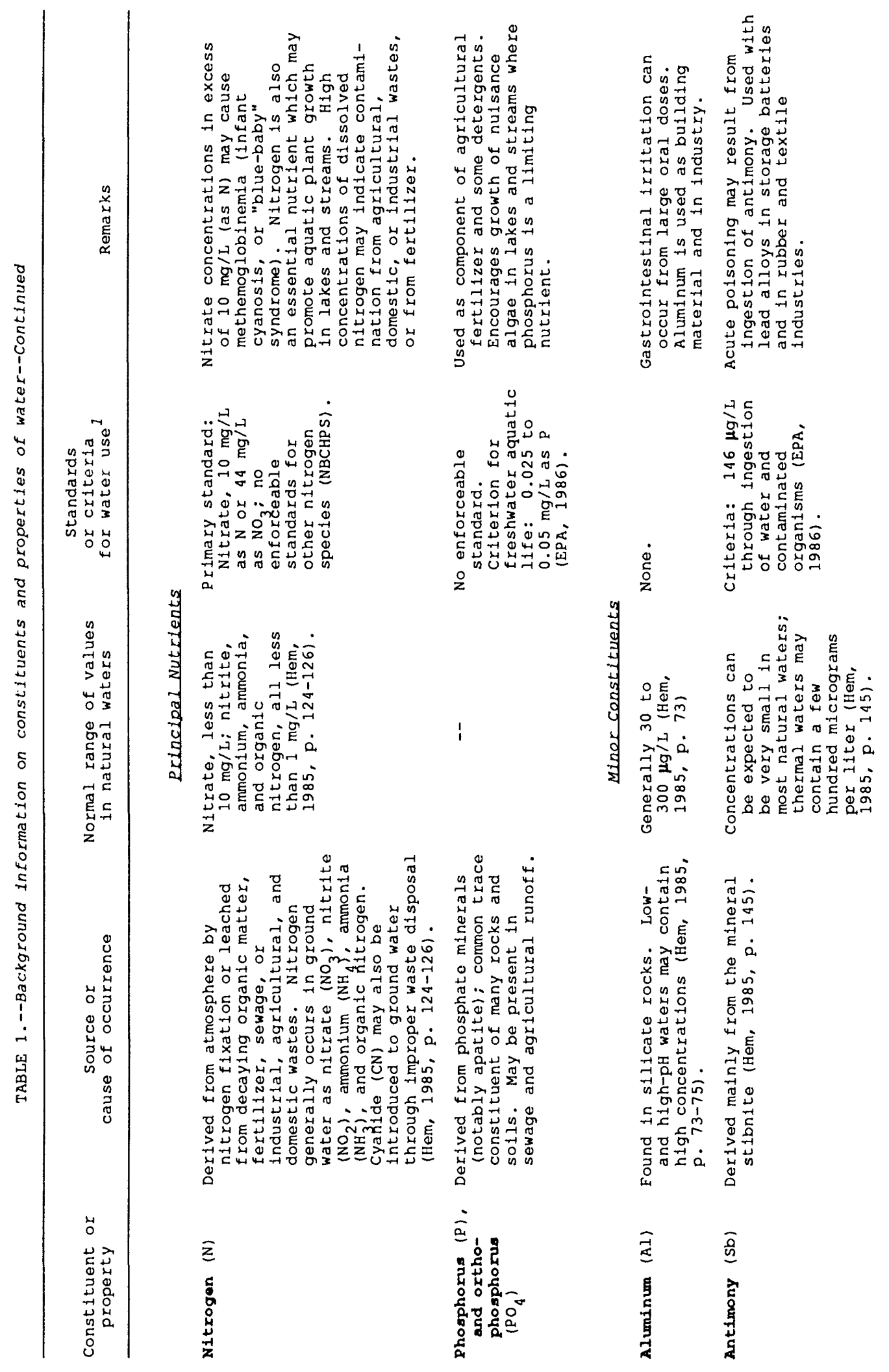




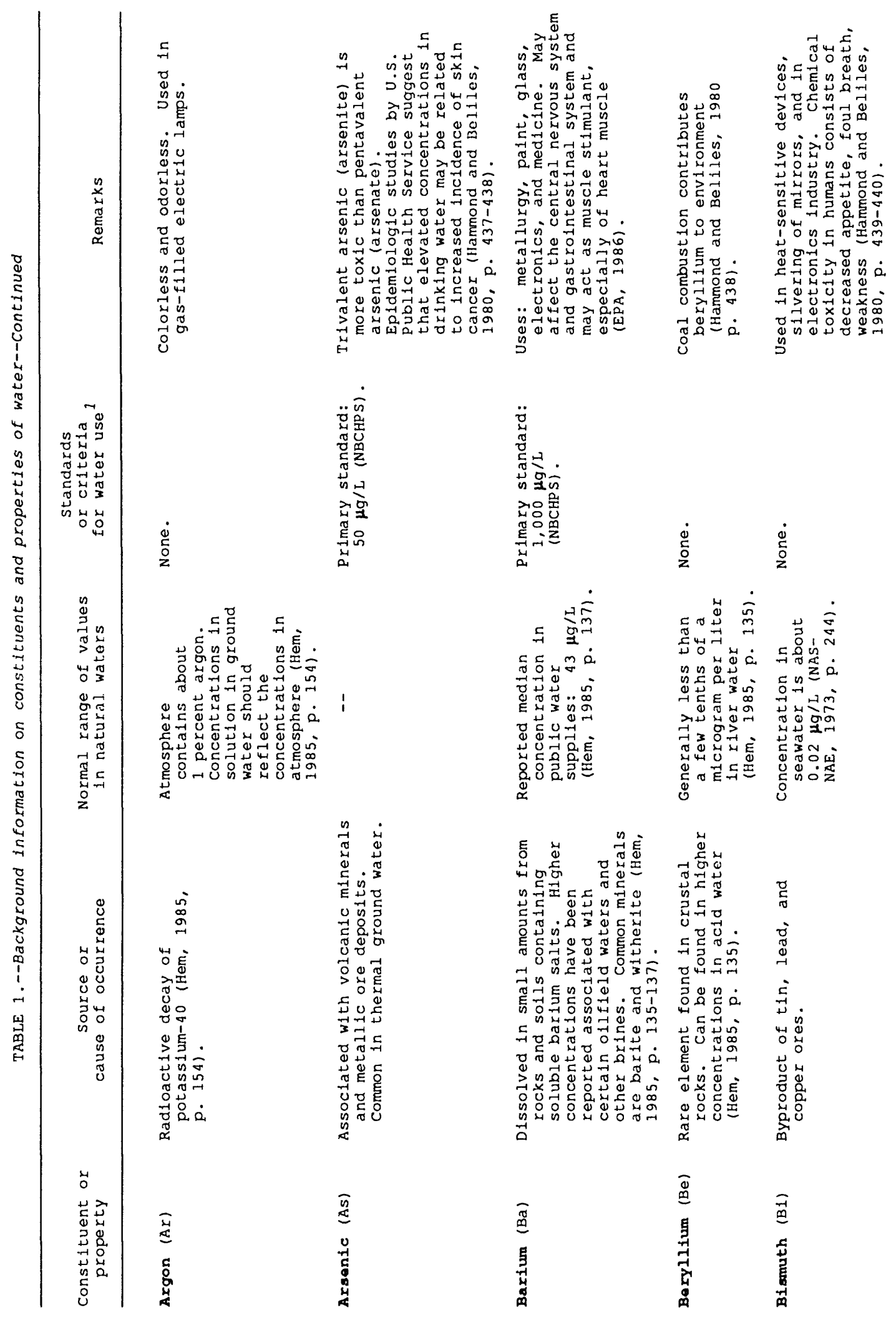




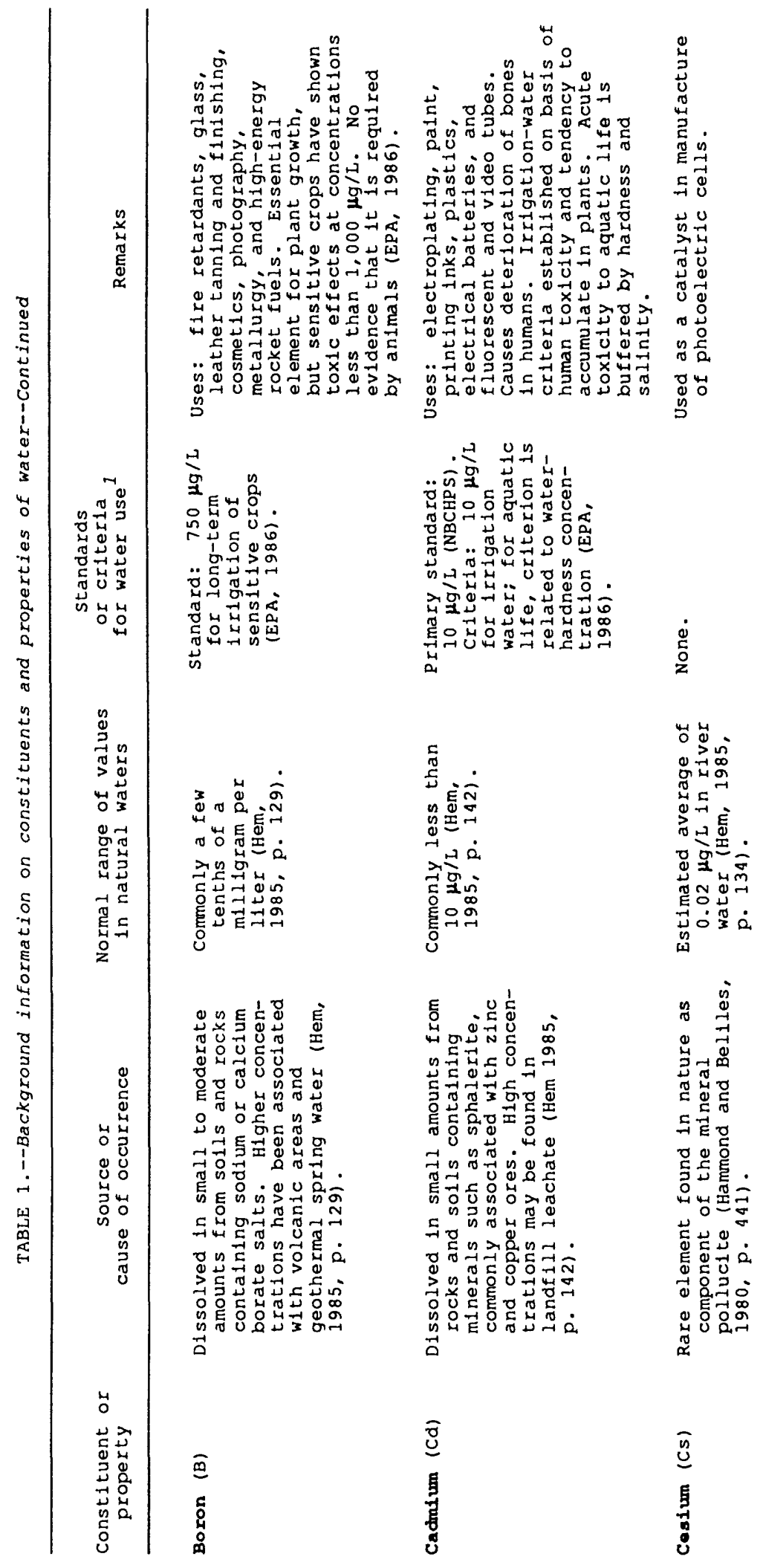




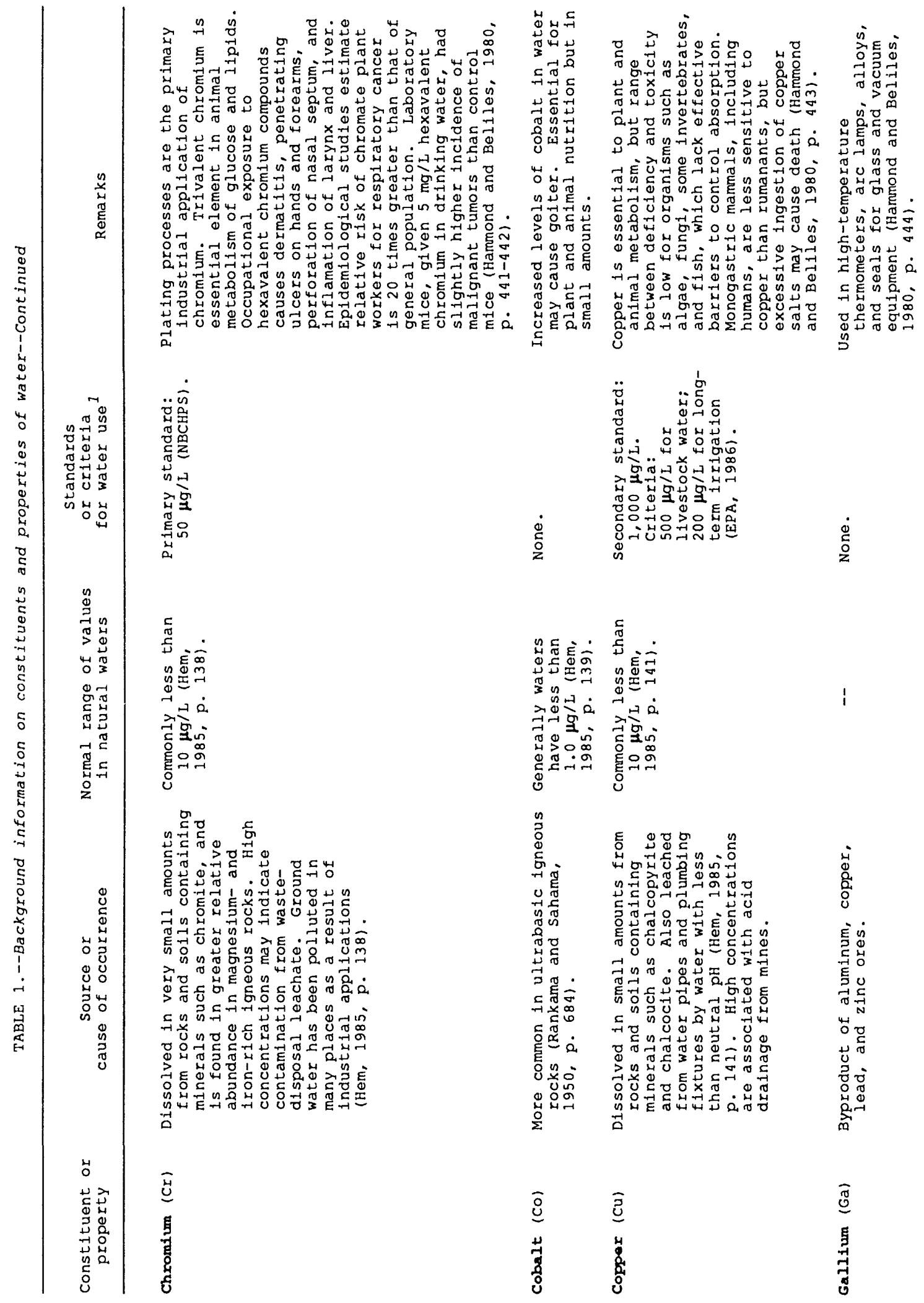




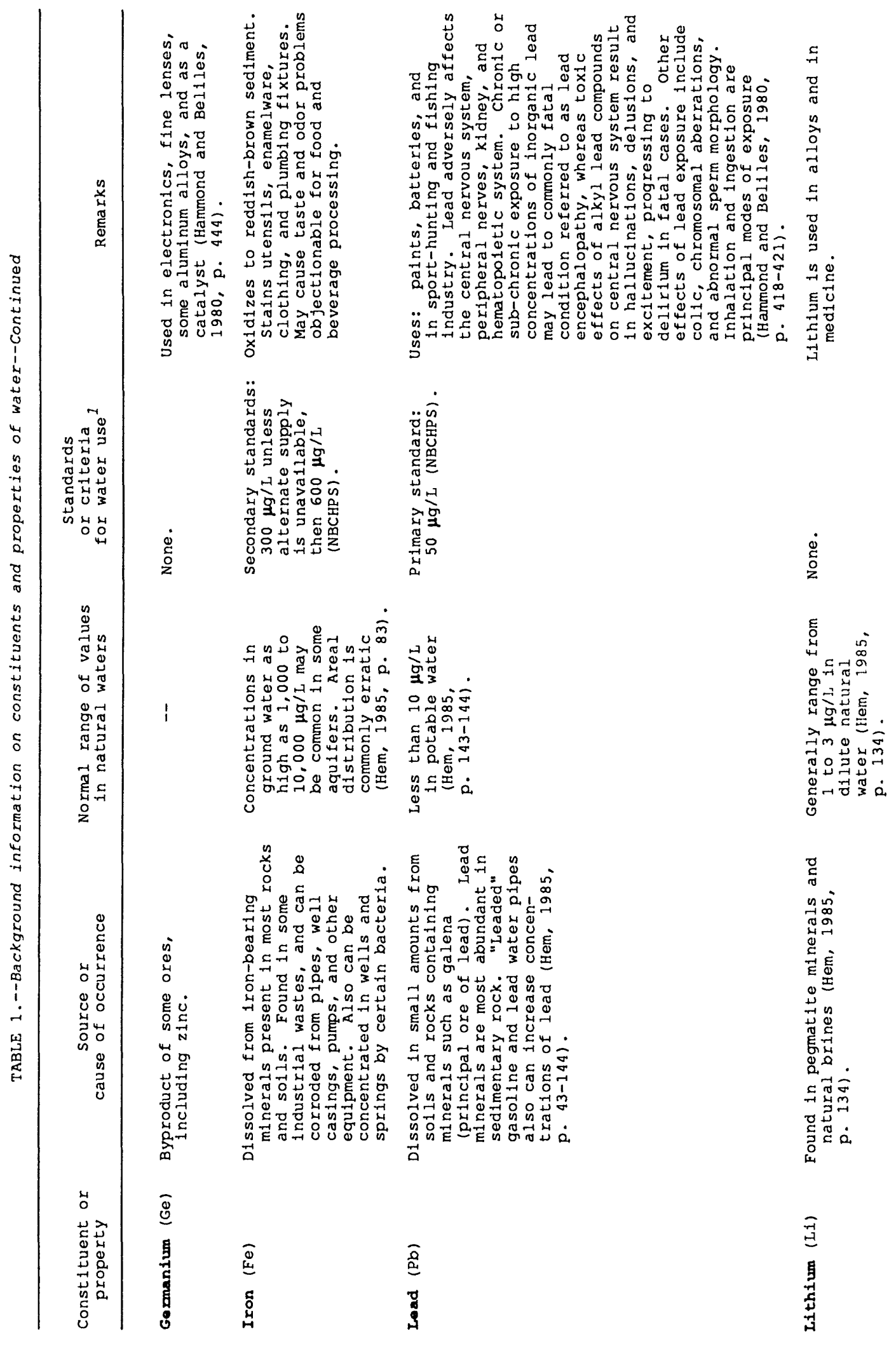




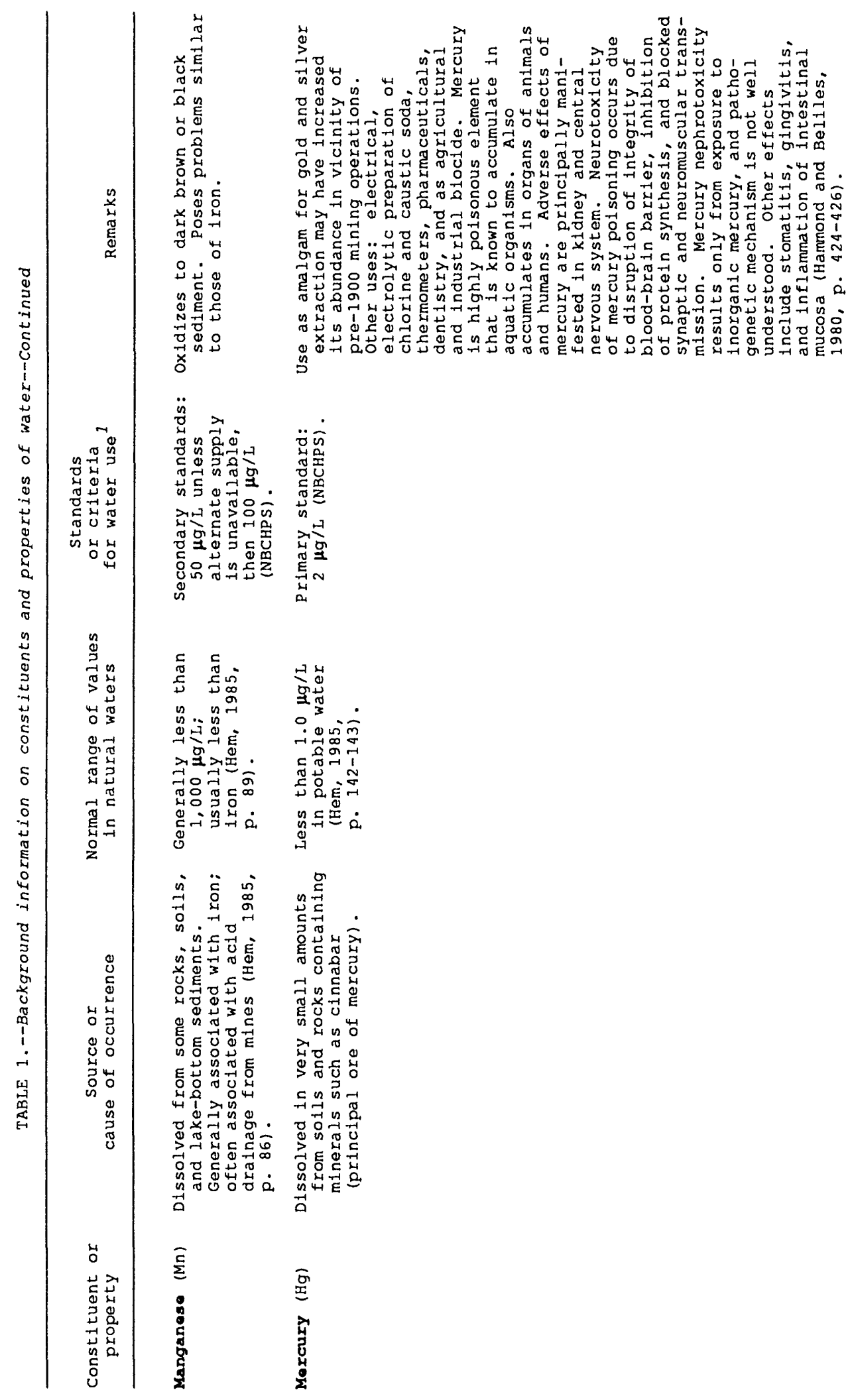




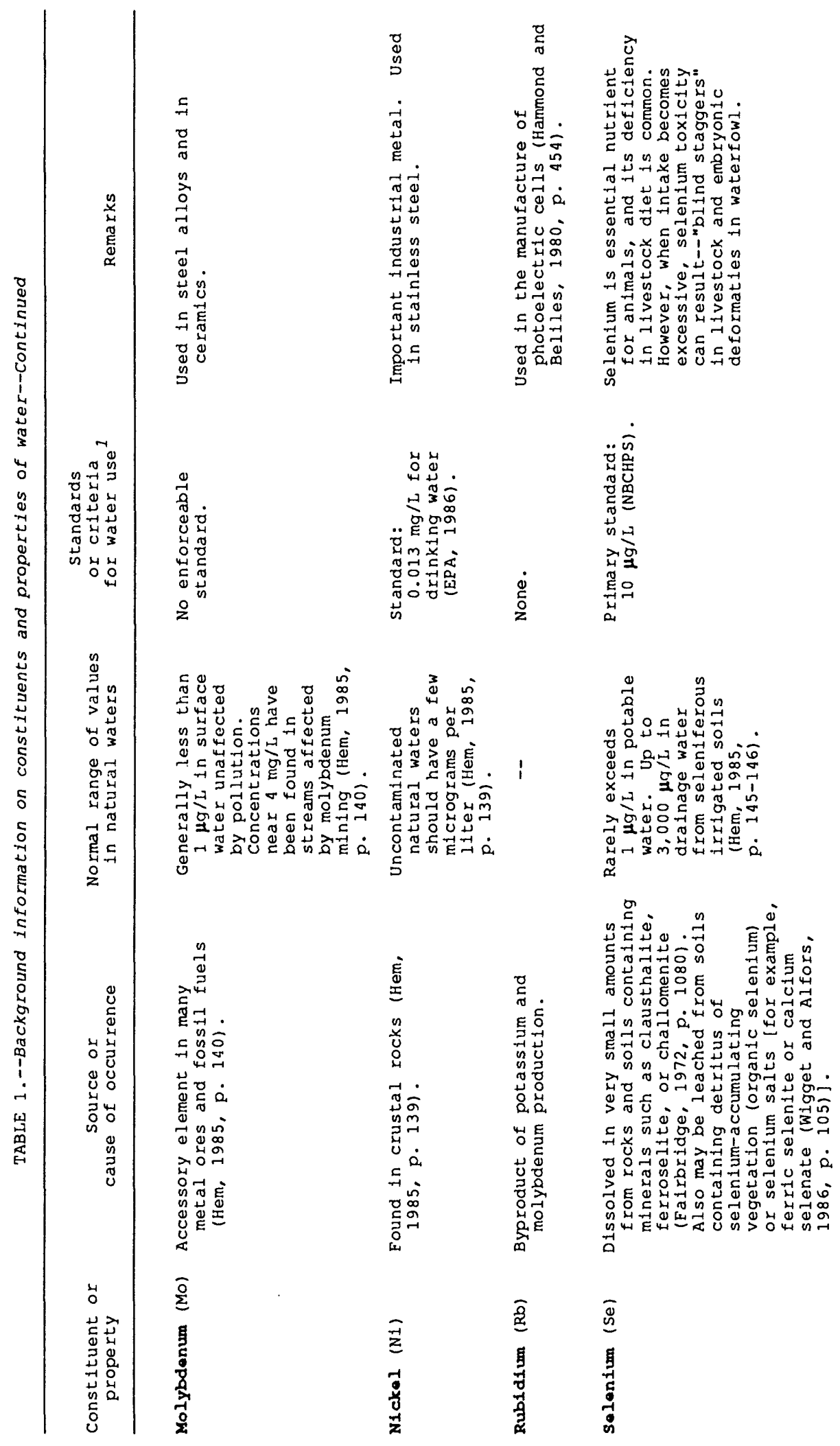




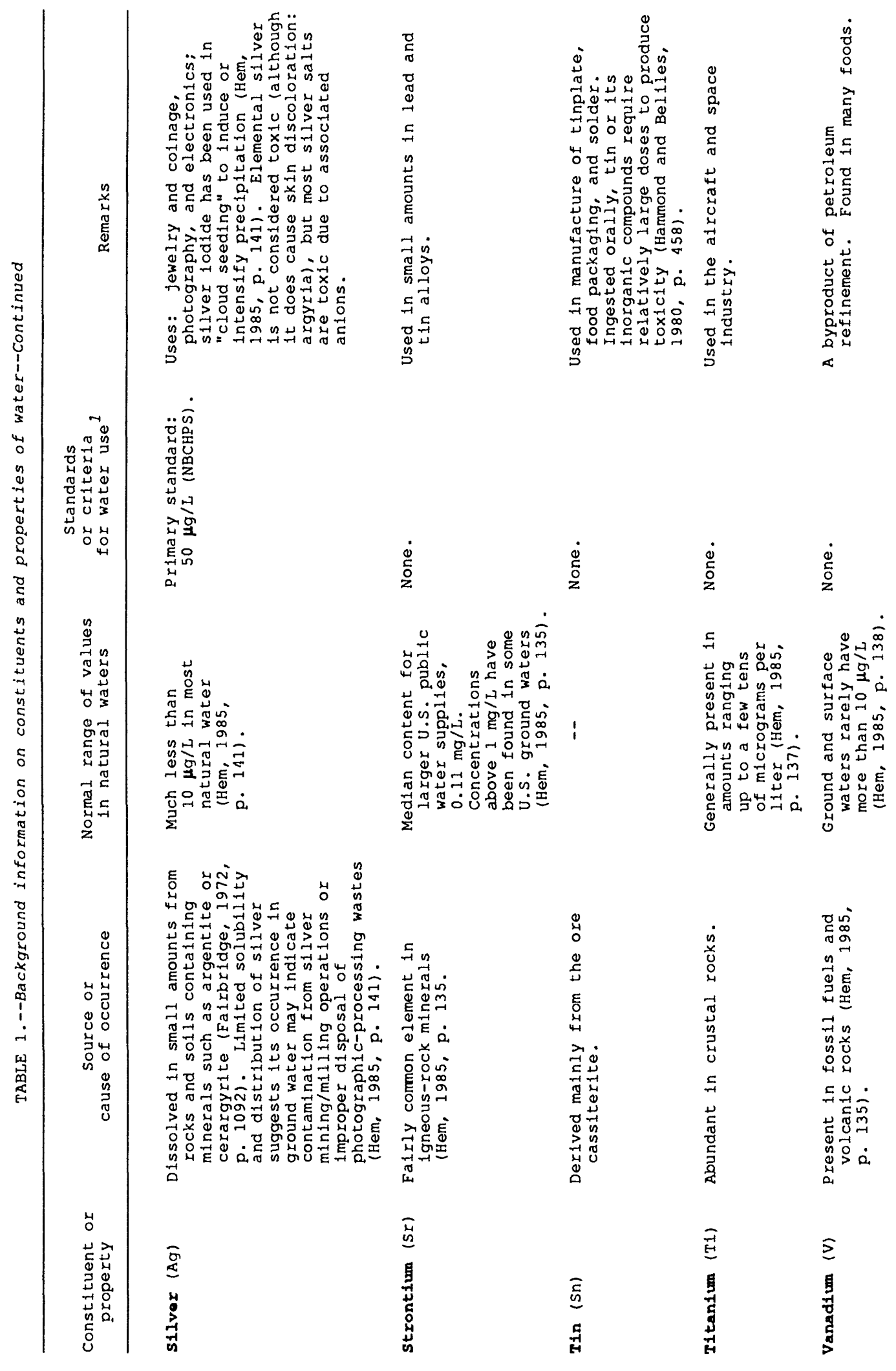




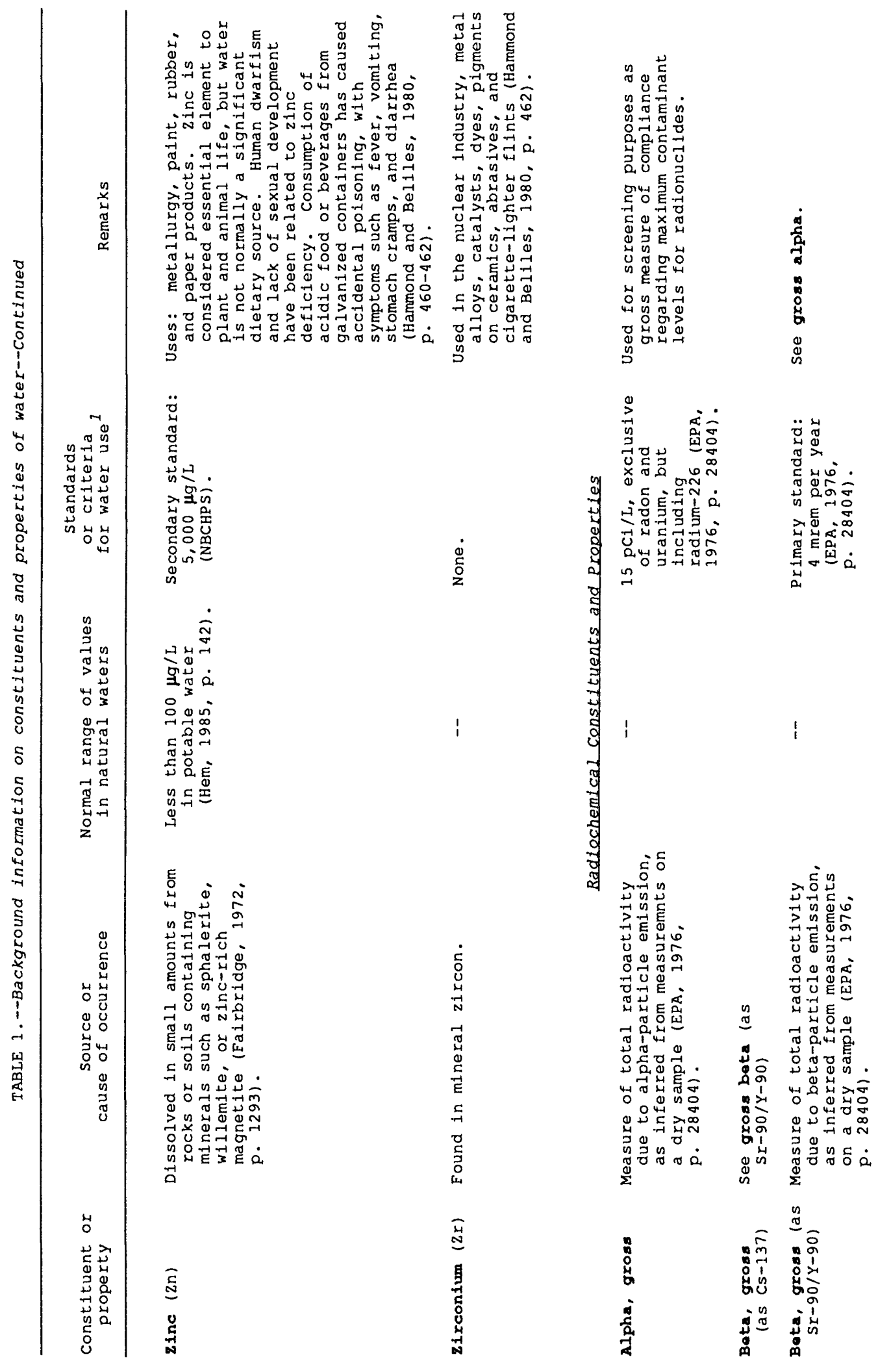




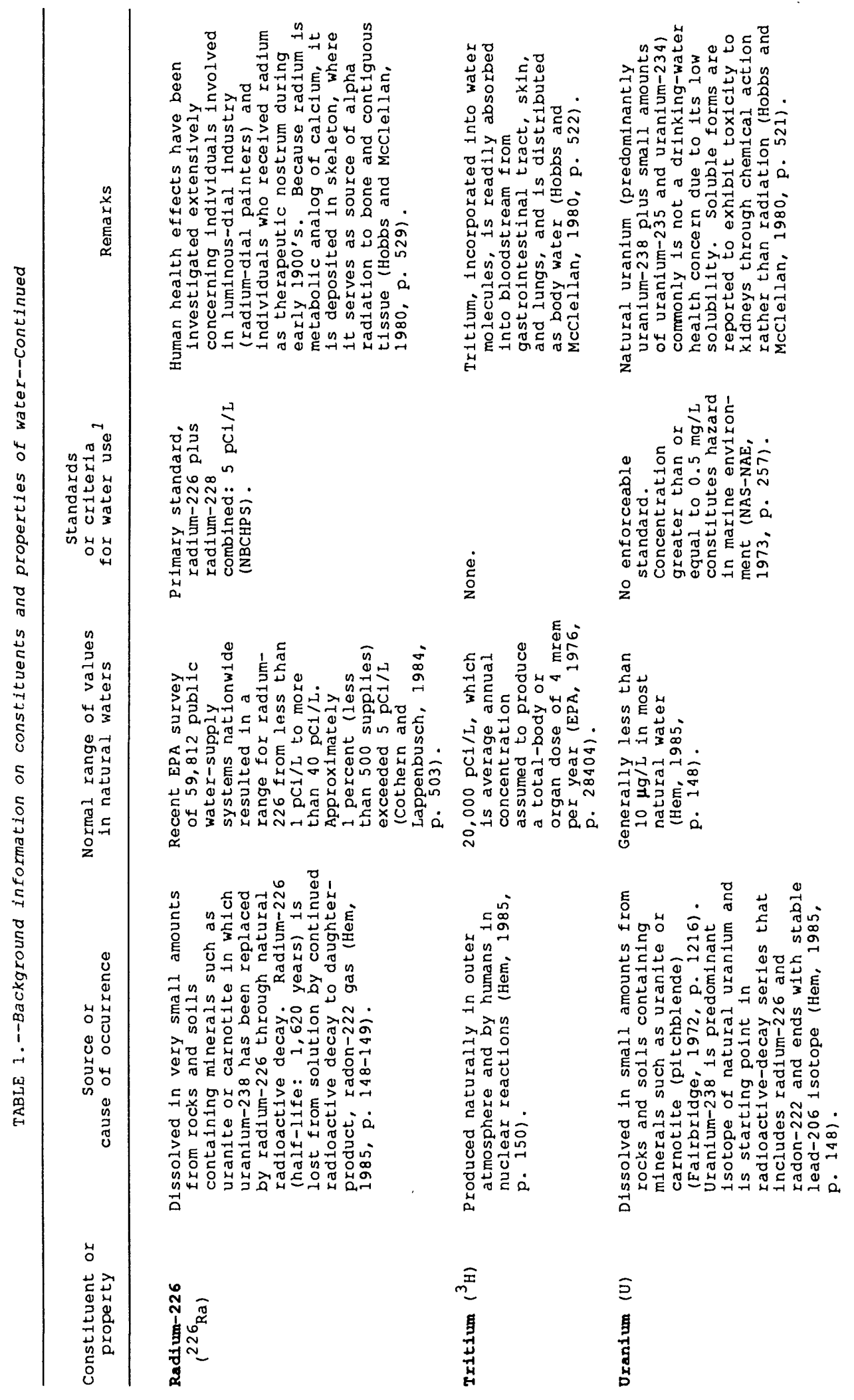




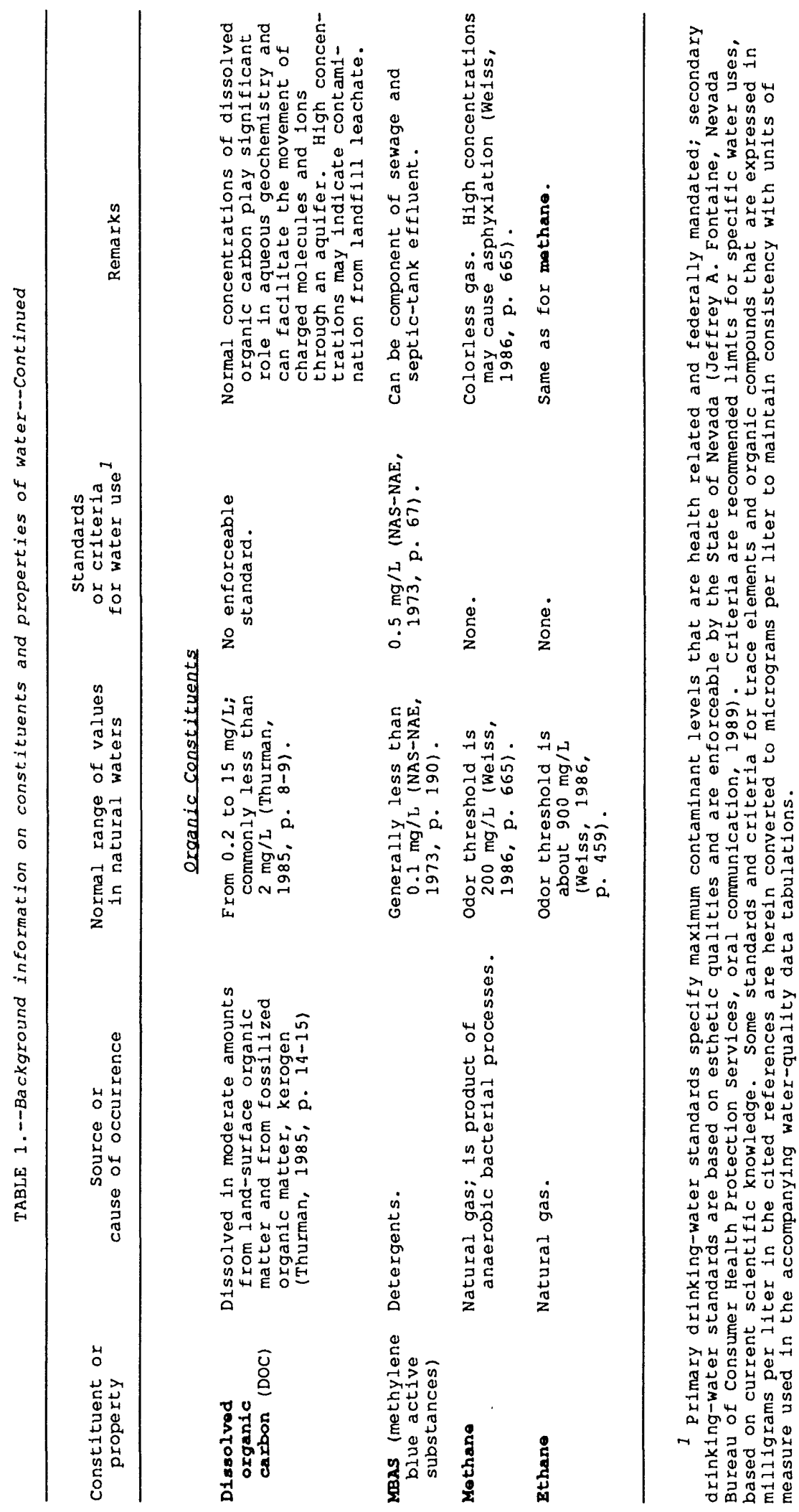


TABLE 2.--Sites where primary drinking-water standards for selected constituents were exceeded

[Locations are shown in figures 3-5]

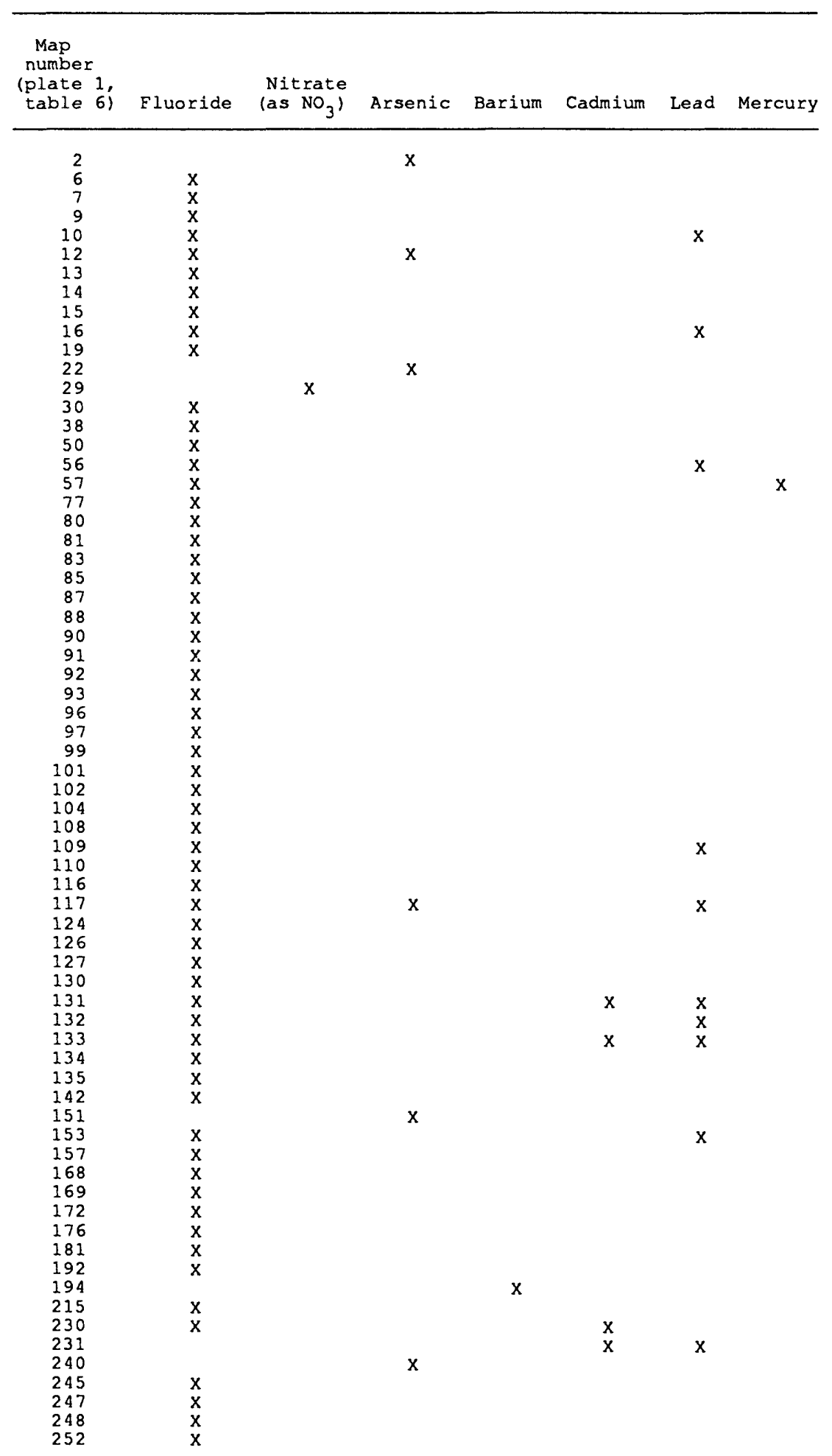


TABLE 2.--Sites where primary drinking-water standards

for selected constituents were exceeded--Continued

\begin{tabular}{|c|c|c|c|c|c|c|c|}
\hline $\begin{array}{c}\text { Map } \\
\text { number } \\
\text { (plate 1, } \\
\text { table 6) }\end{array}$ & Fluoride & $\begin{array}{r}\text { Nitrate } \\
\left(\text { as } \mathrm{NO}_{3}\right)\end{array}$ & Arsenic & Barium & Cadmium & Lead & Mercury \\
\hline 253 & $x$ & & & & & & \\
\hline 255 & $\ddot{x}$ & & & & & & \\
\hline 256 & $\hat{x}$ & & & & & & \\
\hline 257 & & & & & & & \\
\hline $\begin{array}{l}258 \\
260\end{array}$ & & & & $x$ & & & \\
\hline $\begin{array}{l}260 \\
262\end{array}$ & $\begin{array}{l}x \\
x\end{array}$ & & & & & & \\
\hline $\begin{array}{l}262 \\
264\end{array}$ & $x$ & & & & & $x$ & \\
\hline 267 & $x$ & & $x$ & & & & \\
\hline 269 & $x$ & & & & & & \\
\hline 270 & $x$ & & & & & & \\
\hline 271 & $x$ & & & & & & \\
\hline 272 & $x$ & & & & & & \\
\hline 273 & $x$ & & & & & & \\
\hline 274 & $x$ & & & & & & \\
\hline 275 & $x$ & & & & & & \\
\hline 276 & $x$ & & & & & & \\
\hline 277 & $x$ & & & & & & \\
\hline 278 & $x$ & & & & & & \\
\hline 280 & $x$ & & & & & $x$ & $x$ \\
\hline 281 & $x$ & & & & & $x$ & \\
\hline 282 & $\ddot{x}$ & & & & & & \\
\hline 283 & $x$ & & & & & & \\
\hline 293 & $x$ & & & & & & \\
\hline 298 & & & & & $x$ & $x$ & \\
\hline 307 & & & & & & $x$ & \\
\hline 308 & & & & & & $x$ & \\
\hline 311 & $x$ & & & & & & \\
\hline 313 & & & & & $x$ & $x$ & \\
\hline 318 & $x$ & & & & & & \\
\hline 320 & $x$ & & & & & & \\
\hline 327 & $x$ & & & & & & \\
\hline 338 & $x$ & & & & & & \\
\hline 345 & $x$ & & & & $\mathrm{x}$ & & \\
\hline 350 & $x$ & & & & & & \\
\hline 352 & $\mathrm{x}$ & & & & & & \\
\hline $\begin{array}{l}363 \\
366\end{array}$ & $x$ & & & & & $x$ & \\
\hline $\begin{array}{l}366 \\
369\end{array}$ & $\begin{array}{l}x \\
x\end{array}$ & & & & $x$ & $x$ & \\
\hline 370 & $\hat{x}$ & & $x$ & & & & \\
\hline 371 & $x$ & & $x$ & & & & $x$ \\
\hline 372 & $\ddot{x}$ & & $x$ & & & & \\
\hline 377 & $x$ & & & & & & \\
\hline 380 & $x$ & & & & & & \\
\hline 381 & $x$ & & & & $x$ & $x$ & \\
\hline 382 & $\hat{x}$ & & & & $\ddot{x}$ & $\ddot{x}$ & \\
\hline 395 & $x$ & & & & & & \\
\hline 402 & & & & & $x$ & $x$ & \\
\hline 434 & $x$ & & & & & & \\
\hline 448 & $x$ & & & & & & \\
\hline 457 & $x$ & & & & & & \\
\hline 496 & & $x$ & & & & & \\
\hline 506 & $x$ & & & & & & \\
\hline 507 & $\ddot{x}$ & & & & & & \\
\hline 518 & $x$ & & $x$ & & & & \\
\hline & $x$ & & $x$ & & & & \\
\hline 522 & & & & & & $x$ & \\
\hline 525 & $x$ & & & & & & \\
\hline 526 & $\mathrm{x}$ & & & & & & \\
\hline
\end{tabular}




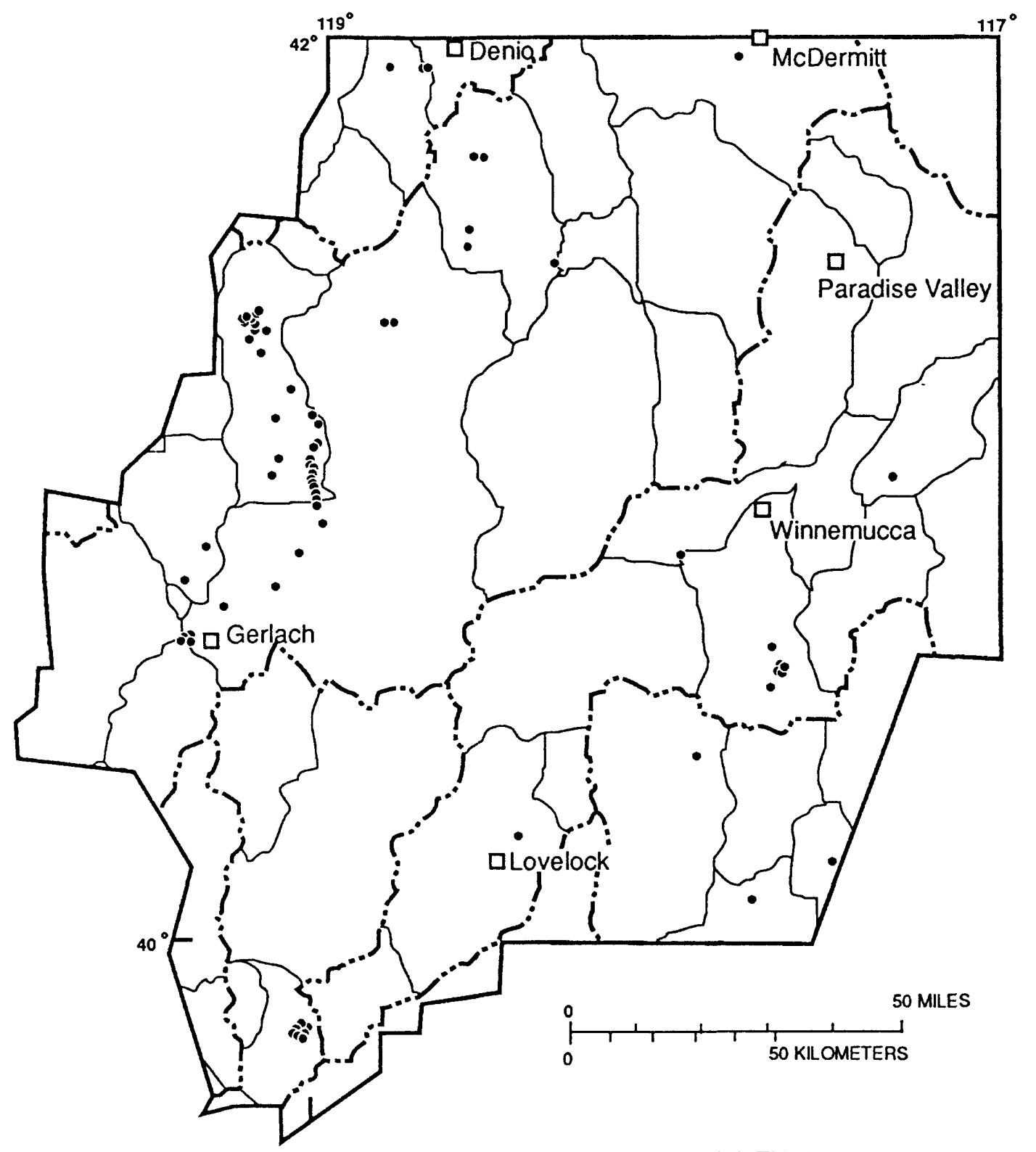

EXPLANATION

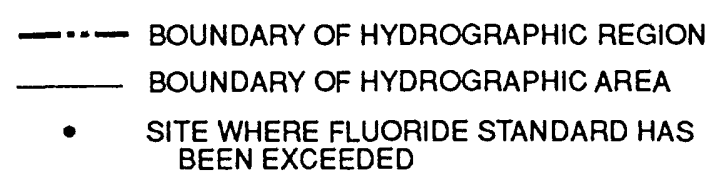

FIGURE 3.--Sites where primary drinking-water standard for fluoride $(4.0 \mathrm{mg} / \mathrm{L})$ has been exceeded. Total sites, 110 . 


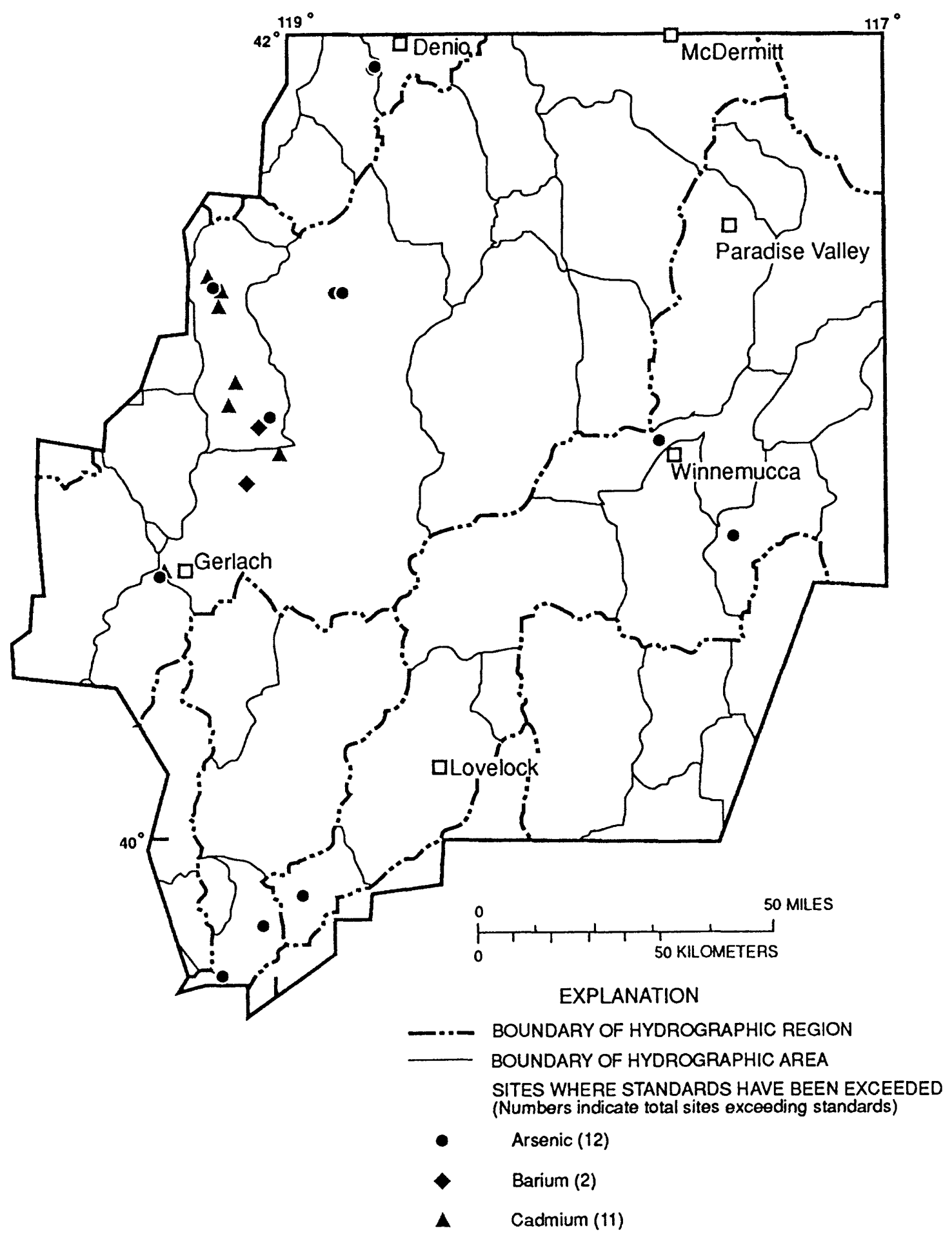

FIGURE 4.--Sites where primary drinking-water standards for arsenic ( $50 \mu \mathrm{g} / \mathrm{L})$, barium $(1,000 \mu \mathrm{g} / \mathrm{L})$, and cadmlum $(10 \mu \mathrm{g} / \mathrm{L})$ have been exceeded. 


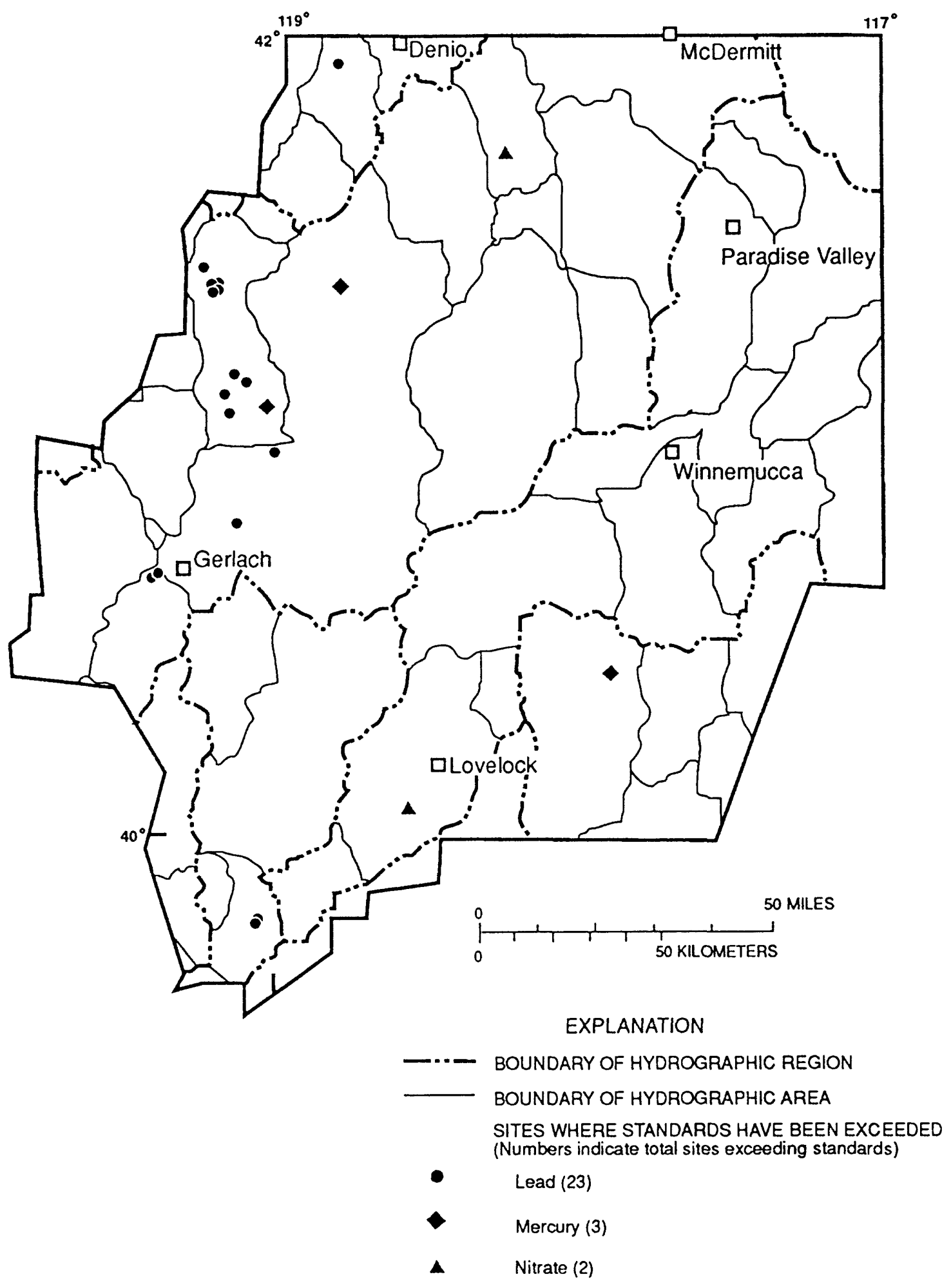

FIGURE 5.--Sites where primary drinking-water standards have been exceeded for lead $(50 \mu \mathrm{g} / \mathrm{L})$, mercury $(2 \mu \mathrm{g} / \mathrm{L})$, and nitrate $\left(44 \mathrm{mg} / \mathrm{L}\right.$ as $\left.\mathrm{NO}_{3}\right)$. 
TABLE 3.--Recommended criteria for dissolved constituents and properties of water used for agriculture

(Erom National Academy of Sciences and National Academy of Engineering, (1973, p. 298-366) unless otherwise noted. Abbreviations: Type of use.--I, irrigation; L, livestock. Units of measure. $-\mu S / \mathrm{cm}$, microsiemens per centimeter at $25^{\circ} \mathrm{Celsius;} \mathrm{mg} / \mathrm{L}$, milligrams per liter. symbols: <, less than; >, greater than; $\mathbf{S}$, less than or equal to.]

\begin{tabular}{|c|c|c|}
\hline Constituent & Use & Criteria for use \\
\hline $\mathrm{pH}$ & $\mathbf{L}$ & $\begin{array}{l}\text { No limit, but waters with pH less than } 4.5 \text { can } \\
\text { affect the toxicity of other constituents. } \\
4.5-9.0 \text { pH units with care taken to look at } \\
\text { possible harmful secondary effects. }\end{array}$ \\
\hline Dissolved solids & L & $\begin{array}{l}\text { Upper limit } 5,000 \mathrm{mg} / \mathrm{L} \text { stated by some } \\
\text { investigators; for best growth of animals } \\
\text { should be considerably below the upper limit } \\
\text { (Hem, } 1985 \text {, p. } 213 \text { ). } \\
\text { < } 500 \mathrm{mg} / \mathrm{L} \text {, no detrimental effects; } 500- \\
1,000 \mathrm{mg} / \mathrm{L} \text {, can have detrimental effects to } \\
\text { sensitive crops; } 1,000-2,000 \mathrm{mg} / \mathrm{L} \text {, can have } \\
\text { detrimental effects on many crops; } 2,000- \\
5,000 \mathrm{mg} / \mathrm{L} \text {, water can be used for tolerant } \\
\text { crops on permeable soils with careful } \\
\text { management practices. }\end{array}$ \\
\hline \multirow[t]{3}{*}{$\begin{array}{l}\text { Sodium-adsorption } \\
\text { ratio (SAR) and } \\
\text { sodium hazard }\end{array}$} & $\begin{array}{l}\mathrm{L} \\
\mathrm{I}\end{array}$ & $\begin{array}{l}\text { No recommendation. } \\
\text { Four categories of sodium hazard (low, medium, } \\
\text { high, and very high) are defined by decreasing } \\
\text { SAR values with increasing specific-conductance } \\
\text { values. Ranges of SAR in each hazard category, } \\
\text { for specific conductances of } 100 \text { and } 5,000 \\
\mu S / c m \text { are: }\end{array}$ \\
\hline & & $\begin{array}{cc}\text { SAR range for } & \text { SAR range for } \\
100 \mu \mathrm{s} / \mathrm{cm} & 5,000 \mu \mathrm{s} / \mathrm{cm}\end{array}$ \\
\hline & & $\begin{array}{l}\text { Low } \\
\text { Medium } \\
\text { High } \\
\text { Very high }\end{array}$ \\
\hline
\end{tabular}

\begin{tabular}{|c|c|c|}
\hline Sulfide & L & $\begin{array}{l}\text { No recommendation (unpleasant taste and odor } \\
\text { would prevent usage). } \\
\text { No recommendation. }\end{array}$ \\
\hline Fluoride & $\begin{array}{l}\mathrm{L} \\
\mathrm{I}\end{array}$ & $\begin{array}{l}2.0 \mathrm{mg} / \mathrm{L} \text {. } \\
1.0 \mathrm{mg} / \mathrm{L} \text { for continuous use on all soils; } \\
15 \mathrm{mg} / \mathrm{L} \text { for use on neutral and alkaline, fine- } \\
\text { textured soils for } 20 \text { years. }\end{array}$ \\
\hline Nitrite as $\mathrm{N}$ & $\begin{array}{l}\mathrm{L} \\
\mathrm{I}\end{array}$ & $\begin{array}{l}510 \mathrm{mg} / \mathrm{L} \text {, to provide a margin of safety. } \\
\text { No recommendation. }\end{array}$ \\
\hline Nitrate as $\mathrm{NO}_{3}$ & $\begin{array}{l}\mathrm{L} \\
\mathrm{I}\end{array}$ & $\begin{array}{l}400 \mathrm{mg} / \mathrm{L} \text {. } \\
\text { No recommendation. }\end{array}$ \\
\hline Aluminum & L & $\begin{array}{l}5.0 \mathrm{mg} / \mathrm{L} \text {. } \\
5.0 \mathrm{mg} / \mathrm{L} \text { for continuous use on all soils; } \\
20 \mathrm{mg} / \mathrm{i} \text { for use on fine-textured, neutral to } \\
\text { alkaline soils for } 20 \text { years. }\end{array}$ \\
\hline Arsenic & $\begin{array}{l}\text { L } \\
I\end{array}$ & $\begin{array}{l}0.20 \mathrm{mg} / \mathrm{L} \text {. } \\
0.10 \mathrm{mg} / \mathrm{L} \text { for continuous use on all soils: } \\
2.0 \mathrm{mg} / \mathrm{L} \text { for use on fine-textured, neutral to } \\
\text { alkaline soils for up to } 20 \text { years. }\end{array}$ \\
\hline Beryllium & $\begin{array}{l}\mathrm{L} \\
\mathrm{I}\end{array}$ & $\begin{array}{l}\text { No recommendation. } \\
0.10 \mathrm{mg} / \mathrm{L} \text { for continuous use on all soils; } \\
0.50 \mathrm{mg} / \mathrm{L} \text { for use on neutral to alkaline, fine- } \\
\text { textured soils for } 20 \text { years. }\end{array}$ \\
\hline
\end{tabular}


TABLE 3.--Recommended criteria for dissolved constituents and properties of water used for agriculture--Continued

\begin{tabular}{|c|c|c|}
\hline Constituent & Use & Criteria for use \\
\hline Boron & L & $\begin{array}{l}5.0 \mathrm{mg} / \mathrm{L} \text {. } \\
0.75 \mathrm{mg} / \mathrm{L} \text { for long-term irrigation of sensitive } \\
\text { crops (U.S. Environmental Protection Agency, } \\
1986 \text { ). }\end{array}$ \\
\hline Cadmium & L & $\begin{array}{l}0.05 \mathrm{mg} / \mathrm{L} \text {. } \\
0.01 \mathrm{mg} / \mathrm{L} \text { for continuous use on all soils; } \\
0.05 \mathrm{mg} / \mathrm{L} \text { for use on neutral and alkaline, } \\
\text { fine-textured soils for } 20 \text { years. }\end{array}$ \\
\hline Chromium & L & $\begin{array}{l}1.0 \mathrm{mg} / \mathrm{L} \text {. } \\
0.10 \mathrm{mg} / \mathrm{L} \text { for continuous use on all soils: } \\
1.0 \mathrm{mg} / \mathrm{L} \text { for use on on neutral and alkaline, } \\
\text { fine-textured soils for } 20 \text { years. }\end{array}$ \\
\hline Cobalt & L & $\begin{array}{l}1.0 \mathrm{mg} / \mathrm{L} \text {. } \\
0.05 \mathrm{mg} / \mathrm{L} \text { for continuous use on all soils: } \\
5.0 \mathrm{mg} / \mathrm{L} \text { for use on neutral and alkaline, fine- } \\
\text { textured soils for } 20 \text { years. }\end{array}$ \\
\hline Copper & $\begin{array}{l}\mathrm{L} \\
\mathrm{I}\end{array}$ & $\begin{array}{l}0.50 \mathrm{mg} / \mathrm{L} \text {. } \\
0.20 \mathrm{mg} / \mathrm{L} \text { for continuous use on all soils; } \\
5.0 \mathrm{mg} / \mathrm{L} \text { for use on neutral and alkaline, fine- } \\
\text { textured soils for } 20 \text { years. }\end{array}$ \\
\hline Iron & I & $\begin{array}{l}\text { No recommendation. } \\
5.0 \mathrm{mg} / \mathrm{L} \text { for continuous use on all soils; } \\
20 \mathrm{mg} / \mathrm{L} \text { for use on neutral to alkaline soils } \\
\text { for } 20 \text { years. }\end{array}$ \\
\hline Lead & L & $\begin{array}{l}0.10 \mathrm{mg} / \mathrm{L} \text {. } \\
5.0 \mathrm{mg} / \mathrm{L} \text { for continuous use on all soils; } \\
10 \mathrm{mg} / \mathrm{L} \text { for use on neutral and alkaline, fine- } \\
\text { textured soils for } 20 \text { years. }\end{array}$ \\
\hline Lithium & $\begin{array}{l}\mathrm{L} \\
\mathrm{I}\end{array}$ & $\begin{array}{l}\text { No recommendation. } \\
2.5 \mathrm{mg} / \mathrm{L} \text { for continuous use on all soils except } \\
\text { for citrus, where } 0.075 \mathrm{mg} / \mathrm{L} \text { is recommended. }\end{array}$ \\
\hline Manganese & $\begin{array}{l}\text { L } \\
I\end{array}$ & $\begin{array}{l}\text { No recommendation. } \\
0.20 \mathrm{mg} / \mathrm{L} \text { for continuous use on all soils; } \\
10 \mathrm{mg} / \mathrm{L} \text { for use on neutral and alkaline, fine- } \\
\text { textured soils for up to } 20 \text { years. }\end{array}$ \\
\hline Mercury & L & $\begin{array}{l}0.01 \mathrm{mg} / \mathrm{L} \text {. } \\
\text { No recommendation. }\end{array}$ \\
\hline Molybdenum & $\begin{array}{l}\mathrm{L} \\
\mathrm{I}\end{array}$ & $\begin{array}{l}\text { Upper limit has not been set. } \\
0.01 \mathrm{mg} / \mathrm{L} \text { for continuous use on all soils; } \\
0.05 \mathrm{mg} / \mathrm{L} \text { for short-term use on soils that } \\
\text { react with this element. }\end{array}$ \\
\hline Nickel & $\begin{array}{l}L \\
I\end{array}$ & $\begin{array}{l}\text { No recommendation. } \\
0.20 \mathrm{mg} / \mathrm{L} \text { for continuous use on all soils: } \\
2.0 \mathrm{mg} / \mathrm{L} \text { for use on neutral, fine-textured } \\
\text { soils for up to } 20 \text { years. }\end{array}$ \\
\hline Selenium & L & $\begin{array}{l}0.05 \mathrm{mg} / \mathrm{L} \text {. } \\
0.02 \mathrm{mg} / \mathrm{L} \text { for continuous use on all soils. }\end{array}$ \\
\hline Vanadium & $\begin{array}{l}\mathrm{L} \\
\mathrm{I}\end{array}$ & $\begin{array}{l}0.10 \mathrm{mg} / \mathrm{L} \text {. } \\
0.10 \mathrm{mg} / \mathrm{L} \text { for continuous use on all soils; } \\
1.0 \mathrm{mg} / \mathrm{L} \text { for use on neutral and alkaline, fine- } \\
\text { textured soils for } 20 \text { years. }\end{array}$ \\
\hline Zinc & $\begin{array}{l}\mathrm{L} \\
\mathrm{I}\end{array}$ & $\begin{array}{l}25 \mathrm{mg} / \mathrm{L} \text {. } \\
2.0 \mathrm{mg} / \mathrm{L} \text { for continuous use on all soils; } \\
10 \mathrm{mg} / \mathrm{L} \text { for use on neutral and alkaline soils } \\
\text { for } 20 \text { years; on fine-textured, calcareous and } \\
\text { organic soils, the concentrations can exceed } \\
\text { the limit by a factor of } 2 \text { or } 3 \text { with little } \\
\text { toxicity for } 20 \text { years. }\end{array}$ \\
\hline
\end{tabular}


TABLE 4.--Relative tolerance of selected plants to boron (modified from Eaton, 1935)

\begin{tabular}{|c|c|c|}
\hline Sensitive & Semitolerant & Tolerant \\
\hline $\begin{array}{l}\text { Lemon } \\
\text { Grapefruit } \\
\text { Avocado } \\
\text { Orange } \\
\text { Thornless blackberry } \\
\text { Apricot } \\
\text { Peach } \\
\text { Cherry } \\
\text { Apple } \\
\text { Pear } \\
\text { Plum } \\
\text { American elm } \\
\text { Pecan }\end{array}$ & $\begin{array}{l}\text { Lima bean } \\
\text { Sweet potato } \\
\text { Bell pepper } \\
\text { Pumpkin } \\
\text { Zinnia } \\
\text { Oat } \\
\text { Milo } \\
\text { Corn } \\
\text { Wheat } \\
\text { Barley } \\
\text { Field pea } \\
\text { Raddish } \\
\text { Sweet pea (flower) } \\
\text { Tomato } \\
\text { Pima cotton } \\
\text { Acala cotton } \\
\text { Potato } \\
\text { Sunflower }\end{array}$ & $\begin{array}{l}\text { Carrot } \\
\text { Lettuce } \\
\text { Cabbage } \\
\text { Turnip } \\
\text { Onion } \\
\text { Broadbean } \\
\text { Alfalfa } \\
\text { Garden beet } \\
\text { Sugar beet }\end{array}$ \\
\hline
\end{tabular}

\section{Aquatic Iife}

Irrigated farm land can affect the habitat of aquatic life (plant and animal organisms) because runoff and subsurface drainage water from agricultural fields may have higher concentrations of dissolved constituents than the water initially applied to the fields. Irrigation runoff and subsurface drainage water sometimes flow directly into wildlife areas by way of drains (such as those in the Stillwater Wildlife Management Area) and affect the habitat of aquatic life.

Water from wells is seldom used for aquatic habitat, but many springs in the Winnemucca District support aquatic life. If ground water is used to supplement streamflow, aquatic life could also be affected. Physical and chemical changes in an aquatic habitat can alter the behavior of aquatic organisms either directly or through secondary organisms. 
The USGS data base used as a source of water-quality data for this study contains no information on potentially toxic constituents such as pesticides, and has limited data for detergents and most dissolved gases. However, data for other constituents that affect aquatic life, such as alkalinity, pH, dissolved solids, and trace constituents, are included. Table 5 lists criteria for selected constituents and properties of water used for aquatic life.

Water temperature can drastically affect growth of fish and other aquatic life. However, water temperature is not included in table 5 because different species have varying tolerances. Information about how water temperature affects aquatic life is discussed by the U.S. Environmental Protection Agency (1986).

\section{Recreational Use}

Ground water generally is not used for recreation, except where springs provide inflow to streams and where geothermal springs are used for swimming; thus, the water quality of springs can be important.

Swimming in geothermal springs generally does not appreciably increase the deep body temperature in humans (National Academy of Sciences and National Academy of Engineering, 1973, p. 32). Wholebody immersion (swimming or bathing) in water about $40^{\circ} \mathrm{F}$ or lower generally is more harmful than swimming in water about $100^{\circ} \mathrm{F}$. However, the harm to an individual varies with the temperature of the water, duration of exposure, and metabolic rate of the individual (National Academy of Sciences and National Academy of Engineering, p. 33).

The recommended range for $\mathrm{pH}$ of water used for immersion of the human body is from 6.5 to 8.3 . The lacrimal fluid (tears) in the eye has a $\mathrm{pH}$ of about 7.4 and a relatively high buffering capacity (National Academy of Sciences and National Academy of Engineering, 1973, p. 33), thus the $\mathrm{pH}$ of water for swimming should range from about 6.5 to 8.3 to prevent eye irritation.

The recommended chemical characteristics of water used for whole-body immersion ensure that the water is nontoxic to the skin and mucous membranes (National Academy of Sciences and National Academy of Engineering, 1973, p. 30). In addition, water used for whole-body immersion should not contain chemicals that, if ingested in small quantities, would be toxic to humans. 
TABLE 5.--Recommended criteria for aquatic life for selected constituents and properties of water used for aquatic habitat

[Abbreviations and symbols: $\mathrm{mg} / \mathrm{L}$, milligrams per liter; $\mu \mathrm{g} / \mathrm{L}$, micrograms per liter; EPA, U.S. Environmental Protection Agency (1986): NAS-NAE, National Academy of Sciences and National Academy of Engineering (1973, p. 130-193): <, less than; s, less than or equal tol

Constituent or characterist

Criteria for use

Color

Hardness

$\mathrm{pH}$

Alkalinity

Ammonia

Sulfide

Dissclved solids

Nitrite

Nitrate

Phosphorus

Aluminum

Antimony

Arsenic

Barium

Beryllium

Boron
Increased color (in combination with turbidity) should not reduce the depth of the compensation point for photosynthetic activity by more than 10 percent from the seasonally established norm for aquatic life (EPA).

Effects of hardness on freshwater fish and other aquatic life appears to be related to the ions causing the hardness (EPA).

6.5 to $9.0 \mathrm{pH}$ units is considered adequate for freshwater aquatic life. In addition, a water should not have a large fluctuation in daily or seasonal $\mathrm{pH}$ values (EPA).

A minimum concentration has been set at $20 \mathrm{mg} / \mathrm{L}$ unless a lower concentration occurs naturally (EPA).

Ammonia $\left(\mathrm{NH}_{3}\right)$, not the ammonium ion $\left(\mathrm{NH}_{4}^{+}\right)$, has been demonstrated to be the principal toxic form. For additional information see EPA.

$0.002 \mathrm{mg} / \mathrm{L}$ to protect aquatic organisms within the general limits of $\mathrm{pH}$ and water temperature, for total sulfides (NAS-NAE).

An excess of dissolved solids may destroy habitatforming plants. Lakes with $15,000 \mathrm{mg} / \mathrm{L}$ are considered unsuitable for most freshwater fishes (EPA).

$\leq 5 \mathrm{mg} / \mathrm{L}$ should protect most warm-water fish; $<0.06 \mathrm{mg} / \mathrm{L}$ should protect salmonoid fish (EPA).

Concentrations of nitrate that would exhibit toxic effects on warm- or cold-water fish could rarely occur in nature, thus restrictive criteria are not recommended (EPA)

Total phosphorus criteria to control aquatic growth is not presented. Total phosphates as phosphorus should not exceed $0.05 \mathrm{mg} / \mathrm{L}$ in any stream where it enters a lake or reservoir, nor $0.025 \mathrm{mg} / \mathrm{L}$ within the lake or reservoir, to prevent development of biological nuisances and to control accelerated eutrophication (EPA).

Where ionic aluminum is suspected, careful examination of toxicity problems should be made (NAS-NAE).

Acute toxicity to freshwater aquatic life occurs at $9.0 \mathrm{mg} / \mathrm{L}$ (EPA)

Varies between biological species and oxidation state because chemistry of arsenic in water is complex (EPA).

A restrictive criterion for aquatic life appears unwarranted (EPA)

Acute toxicity occurs at concentrations as low as 130 $\mu \mathrm{g} / \mathrm{L}$ (EPA).

Naturally occurring concentrations should have no effect on aquatic Iife (EDA). 
TABLE 5.--Recommended criteria for aquatic life for selected constituents and properties of water used for aquatic habitat--Continued

Constituent or

characteristic

Criteria for use

Cadmium

Chromium

Copper

Iron

Lead

Manganese

Mercury

Nicke1

Selenium

Silver

Zinc
$0.03 \mathrm{mg} / \mathrm{L}$ where total hardness as calcium carbonate is greater than $100 \mathrm{mg} / \mathrm{L} ; 0.004 \mathrm{mg} / \mathrm{L}$ where total hardness as calcium carbonate is less than $100 \mathrm{mg} / \mathrm{L}$ (NAS-NAE) .

Mixed aquatic populations should be protected where concentration of total chromium in water does not exceed $0.05 \mathrm{mg} / \mathrm{L}$ at any one time or place (NAS-NAE).

21 and $34 \mu \mathrm{g} / \mathrm{L}$ (EPA). Criterion calculated according to formula published by EPA, which incorporates an ambient hardness value. These values are based on a hardness value of $200 \mathrm{mg} / \mathrm{L}$ as calcium carbonate. Freshwater aquatic organisms should not be adversely affected if the 4-day average concentration (first value) is not exceeded more than once every 3 years on the average and if the 1 -hour average concentration (second value) is not exceeded more than once every 3 years on the average.

$1.0 \mathrm{mg} / \mathrm{L}$ (EPA).

$0.03 \mathrm{mg} / \mathrm{L}$ (NAS-NAE).

Not considered to be a problem in freshwater (EPA).

$0.0002 \mathrm{mg} / \mathrm{L}$ in unfiltered water (NAS-NAE).

283 and $2,550 \mu \mathrm{g} / \mathrm{L}(\mathrm{EPA})$. Criterion calculated according to formula published by EPA, which incorporates an ambient hardness value. These values are based on a hardness value of $200 \mathrm{mg} / \mathrm{L}$ as calcium carbonate. Freshwater aquatic organisms should not be adversely affected if the 4-day average concentration (first value) is not exceeded more than once every 3 years on the average and if the 1-hour average concentration (second value) is not exceeded more than once every 3 years on the average.

Concentration of total recoverable selenite should not exceed $260 \mu \mathrm{g} / \mathrm{L}$ at any time. Acute toxicity to freshwater aquatic life occurs for inorganic selenate at concentrations of $760 \mu \mathrm{g} / \mathrm{L}$ and would occur at lower concentrations for more sensitive species (EPA).

$13 \mu \mathrm{g} / \mathrm{L}$ (EPA). Criterion calculated according to formula published by EPA, which incorporates an ambient hardness value. These values are based on a hardness value of $200 \mathrm{mg} / \mathrm{L}$ as calcium carbonate.

190 and $210 \mu \mathrm{g} / \mathrm{L}$ (EPA). Criterion calculated according to formula published by EPA, which incorporates an ambient hardness value. These values are based on a hardness value of $200 \mathrm{mg} / \mathrm{L}$ as calcium carbonate. Freshwater aquatic organisms should not be adversely affected if the 4-day average concentration (first value) is not exceeded more than once every 3 years on the average and if the 1-hour average concentration (second value) is not exceeded more than once every 3 years on the average. 


\section{WATER-QUALITY DATA}

This report presents data compiled from published reports, limited NBCHPS analyses, and the USGS water-quality data base. Principal constituents and properties, and the more commonly analyzed trace constituents, are listed in table 6, part A. Part B includes additional data for ions, other trace constituents, gases, radionuclides, and organics. Concentrations of trace constituents in Part $B$ are expressed in micrograms per liter. To convert micrograms per liter to milligrams per liter, multiply by 0.001 . The 530 wells and springs for which data on ground-water quality are available are shown on plate 1.

A brief statistical summary of constituents that had more than five determinations is presented in table 7 . Values with remarks ("less than" values) were used in the calculations; thus, for some constituents the statistics may be skewed higher than the true population statistics.

Stable isotope data were available for some sites (114). The stable isotopes listed in table 8 are carbon-13 relative to carbon-12, deuterium (hydrogen-2) relative to hydrogen-1, and oxygen-18 relative to oxygen-16. Each ratio is determined for a sampled water, and is then compared to a standard. The standard for oxygen-18 and deuterium is the international reference standard known as Vienna Standard Mean ocean water (V-SMOW) and for carbon-13 is the Pee Dee Belemnite (PDB). By convention, the computed results are expressed as "delta carbon-13," "delta deuterium," and "delta oxygen-18"; the units of measure are parts per thousand (abbreviated "permil"). A negative delta value indicates that the sampled water is isotopically lighter than the standard (that is, the sampled water has a smalier proportion of oxygen-18, deuterium, or carbon-13, relative to oxygen-16, hydrogen-1, or carbon-12 than the standard).

\section{REEERENCES CITED}

Arteaga, F.E., 1978, Appraisal of water resources in the Fort McDermitt Indian Reservation, Humboldt County, Nevada: U.S. Geological Survey Open-File Report 78-139, $49 \mathrm{p}$.

Cohen, Philip, 1962, Preliminary results of hydrogeochemical studies in the Humboldt River Valley near Winnemucca, Nevada: Nevada Department of Conservation and Natural Resources, Water Resources Bulletin 19, $27 \mathrm{p}$.

---1963, An evaluation of the water resources of the Humboldt River Valley near Winnemucca, Nevada: Nevada Department of Conservation and Natural Resources, water Resources Bulletin 24, $103 \mathrm{p}$.

---1964 , A brief appraisal of the ground-water resources of the Grass Valley area, Humboldt and Pershing Counties, Nevada: Nevada Department of Conservation and Natural Resources, GroundWater Resources - Reconnaissance Report 29, 40 p.

Cohen, Philip, and Everett, D.E., 1963, A brief appraisal of the ground-water hydrology of the Dixie-Fairview Valley area, Nevada: Nevada Department of Conservation and Natural Resources, GroundWater Resources - Reconnaissance Report 23, $40 \mathrm{p}$. 
Cothern, C.R., and Lappenbusch, W.L., 1984, Copliance data for the occurrence of radium and gross- $\alpha$ particle activity in drinking water supplies in the United States: Health Physics, v. 46, no. 3, p. 503-510.

Eakin, T.E., 1962, Ground-water appraisal of the Imlay area, Humboldt River basin, Pershing County, Nevada: Nevada Department of Conservation and Natural Resources, Ground-Water Resources Reconnaissance Report 5, $54 \mathrm{p}$.

Eaton, F.M., 1935, Boron in soils and irrigation waters and its effect on plants with particular reference to the San Joaquin Valley of California: U.S. Department of Agriculture Technical Bulletin $448,131 \mathrm{p}$.

Everett, D.E., and Rush, F.E., 1965, Water-resources appraisal of Lovelock Valley, Pershing County, Nevada: Nevada Department of Conservation and Natural Resources, Water Resources Reconnaissance Report $32,40 \mathrm{p}$.

Fairbridge, R.W., ed., 1972, The encyclopedia of geochemistry and environmental sciences, in Encyclopedia of earth sciences series: Stroudsburg, Pa., Dowden, Hutchinson, and Ross, v. IVA, $1321 \mathrm{p}$.

Glancy, P.A., and Rush, F.E., 1968, Water-resources appraisal of Smoke Creek-San Emidio Desert area, Nevada and California: Nevada Department of Conservation and Natural Resources, Water Resources Reconnaissance Report 44, $57 \mathrm{p}$.

Hammond, P.B., and Beliles, R.P., 1980, Metals, in Doull, J., Klaassen, C.D., and Amdur, M.O., eds., Casarett and Doull's toxicology: New York, Macmillan, p. 409-467.

Harrill, J.R., 1969, Hydrologic response to irrigation pumping in Hualapai Flat, Washoe, Pershing, and Humboldt Counties, Nevada, 1960-67: Nevada Division of Water Resources, Bulletin 37, 75 .

---1970, water-resources appraisal of the Granite Springs Valley area, Pershing, Churchill, and Lyon Counties, Nevada: Nevada Division of Water Resources, Reconnaissance Report 55, $36 \mathrm{p}$.

Harrill, J.R., and Moore, D.O., 1970, Effects of ground-water development on the water regimen of Paradise Valley, Humboldt County, Nevada, 1948-68, and hydrologic reconnaissance of the tributary areas: Nevada Division of Water Resources, Bulletin $39,123 \mathrm{p}$.

Hem, J.D., 1985, Study and interpretation of the chemical characteristics of natural water ( $3 d$ ed.): U.S. Geological Survey Water-Supply Paper 2254, $263 \mathrm{p}$.

Hobbs, C.H., and McClellan, R.O., 1980, Radiation and radioactive materials, in Doull, J., Klaassen, C.D., and Amdur, M.O., eds., Casarett and Doull's toxicology: New York, Macmillan, P. 497-530.

Huxel, C.J., Jr., 1966, Effects of irrigation development on the water supply of Quinn River Valley area, Nevada and Oregon, 1950-64: Nevada Department of Conservation and Natural Resources, Water Resources Bulletin $34,80 \mathrm{p}$. 
Loeltz, O.J., and Phoenix, D.A., 1955, Geology and ground-water resources of Buena Vista Valley, Pershing County, Nevada: Nevada State Engineer, Water Resources Bulletin 13, 51 p.

Loeltz, O.J., Phoenix, D.A., and Robinson, T.W., 1949, Ground water in Paradise Valley, Humboldt County, Nevada: Nevada State Engineer, Water Resources Bulletin 10, $61 \mathrm{p}$.

Malmberg, G.T., and Worts, G.F., 1966, The effects of pumping on the hydrology of Kings River Valley, Humboldt County, Nevada, 1957-64: Nevada Department of Conservation and Natural Resources, Water Resources Bullet in 31, $57 \mathrm{p}$.

National Academy of Sciences and National Academy of Engineering, 1973, Water-quality criteria, 1972: U.S. Environmental Protection Agency Report, EPA R3-73-033, 594 p.

National Climatic Center, 1987, Climatological data, annual summary, Nevada, 1986: Asheville, N.C., U.S. National Oceanic and Atmospheric Administration, v. 101, no. 13.

Nevada Bureau of Consumer Health Protection Services, 1980, Watersupply regulations, Part I. Water-quality standards-Monitoring, recordkeeping, and reporting: Nevada Bureau of Consumer Health Protection Services Report, $17 \mathrm{p}$.

Rankama, Kalervo, and Sahama, T.G., 1950, Geochemistry: Chicago, University of Chicago Press, $912 \mathrm{p}$.

Rush, F.E., 1968, Index of hydrographic areas in Nevada: Nevada Division of water Resources, Information Report 6, $38 \mathrm{p}$.

Sinclair, W.C., 1962a, Ground-water resources of Pine Forest Valley, Humboldt County: Nevada Department of Conservation and Natural Resources, Ground-Water Resources - Reconnaissance Report 4, $22 \mathrm{p}$.

---1962b, Ground-water resources of Desert Valley, Humboldt and Pershing Counties, Nevada: Nevada Department of Conservation and Natural Resources, Ground-Water Resources - Reconnaissance Report 7, $23 \mathrm{p}$.

1962c, Ground-water resources of Hualapai Flat, Washoe, Pershing, and Humboldt Counties: Nevada Department of Conservation and Natural Resources, Ground-Water Resources - Reconnaissance Report 11, 16 p.

---1963a, Ground-water appraisal of the Black Rock Desert area, northwestern Nevada: Nevada Department of Conservation and Natural Resources, Ground-Water Resources - Reconnaissance Report 20, 32 p.

---1963b, Ground-water appraisal of the Pueblo Valley-Continental Lake region, Humboldt County, Nevada: Nevada Department of Conservation and Natural Resources, Ground-Water Resources Reconnaissance Report 22, 25 p.

Smith, R.P., 1980, Toxic responses of the blood, in Doull, J., Klaassen, C.D., and Amdur, M.O., eds., Casarett and Doull's toxicology: New York, Macmillan, p. 311-354. 
Thodal, C.E., 1989, Data on ground-water quality, Carson Valley and Topaz Lake areas, Douglas County, Nevada, for year ending September 1986: U.S. Geological Survey Open-File Report 88-453, $55 \mathrm{p}$.

Thurman, E.M., 1985, Organic geochemistry of natural waters: Dordrecht, The Netherlands, Martinus Nijhoff/Dr W. Junk Publishers, $497 \mathrm{p}$.

U.S. Environmental Protection Agency, 1976, Interim primary drinking water regulations--Promulgation of regulations on radionuclides: Eederal Register, v. 41, no. 133, Friday, July 9, 1976, Part II, p. 28402-29409.

- - 1986, Quality criteria for water, 1986: Office of Water Regulations and Standards, Report EPA-440/5-86-001, unpaginated.

U.S. Salinity Laboratory Staff, 1954, Diagnosis and improvement of saline and alkali soils: U.S. Department of Agriculture Handbook $60,160 \mathrm{p}$.

Van Denburgh, A.S., Lamke, R.D., and Hughes, J.L., 1973, A brief water-resources appraisal of the Truckee River basin, western Nevada: Nevada Division of Water Resources, Reconnaissance Report $57,122 \mathrm{p}$.

Visher, F.N., 1957, Geology and ground-water resources of Quinn River Valley, Humboldt County, Nevada: Nevada State Engineer, Water Resources Bulletin 14, $55 \mathrm{p}$.

Weiss, G., ed., 1986, Hazardous chemical data book: New Jersey, Noyes Data Corporation, 1069 p.

Welch, A.H., and Preissler, A.M., 1990, Geothermal resources of the western arm of the Black Rock Desert, northwestern Nevada--Part II, aqueous geochemistry and hydrology: U.S. Geological survey Water-Resources Investigation Report 87-4062, $91 \mathrm{p}$.

Welch, A.H., and Williams, R.P., 1987a, Data on ground-water quality for the McDermitt $1^{\circ} \times 2^{\circ}$ quadrangle, northern Nevada: U.S. Geological Survey Open-File Report 85-648-E, 1 sheet.

$---1987 \mathrm{~b}$, Data on ground-water quality for the Lovelock $1^{\circ} \times 2^{\circ}$ quadrangle, western Nevada: U.S. Geological Survey Open-File Report $85-648-F, 1$ sheet.

----1987c, Data on ground-water quality for the Winnemucca $1^{\circ} \times 2^{\circ}$ quadrangle, central Nevada: U.S. Geological Survey Open-File Report 85-648-G, 1 sheet.

$---1987 d$, Data on ground-water quality for the Reno $1^{\circ} \times 2^{\circ}$ quadrangle, western Nevada: U.S. Geological Survey Open-File Report 85-648-H, 1 sheet.

Wigget, Gail, and Alfors, John, 1986, Selenium: California Geology, v. 39, no. 5, p. 99-107.

Zones, C.P., 1961, Ground-water reconnaissance of winnemucca Lake Valley, Pershing and Washoe Counties, Nevada: U.S. Geological Survey water-Supply Paper 1539-C, $18 \mathrm{p}$. 


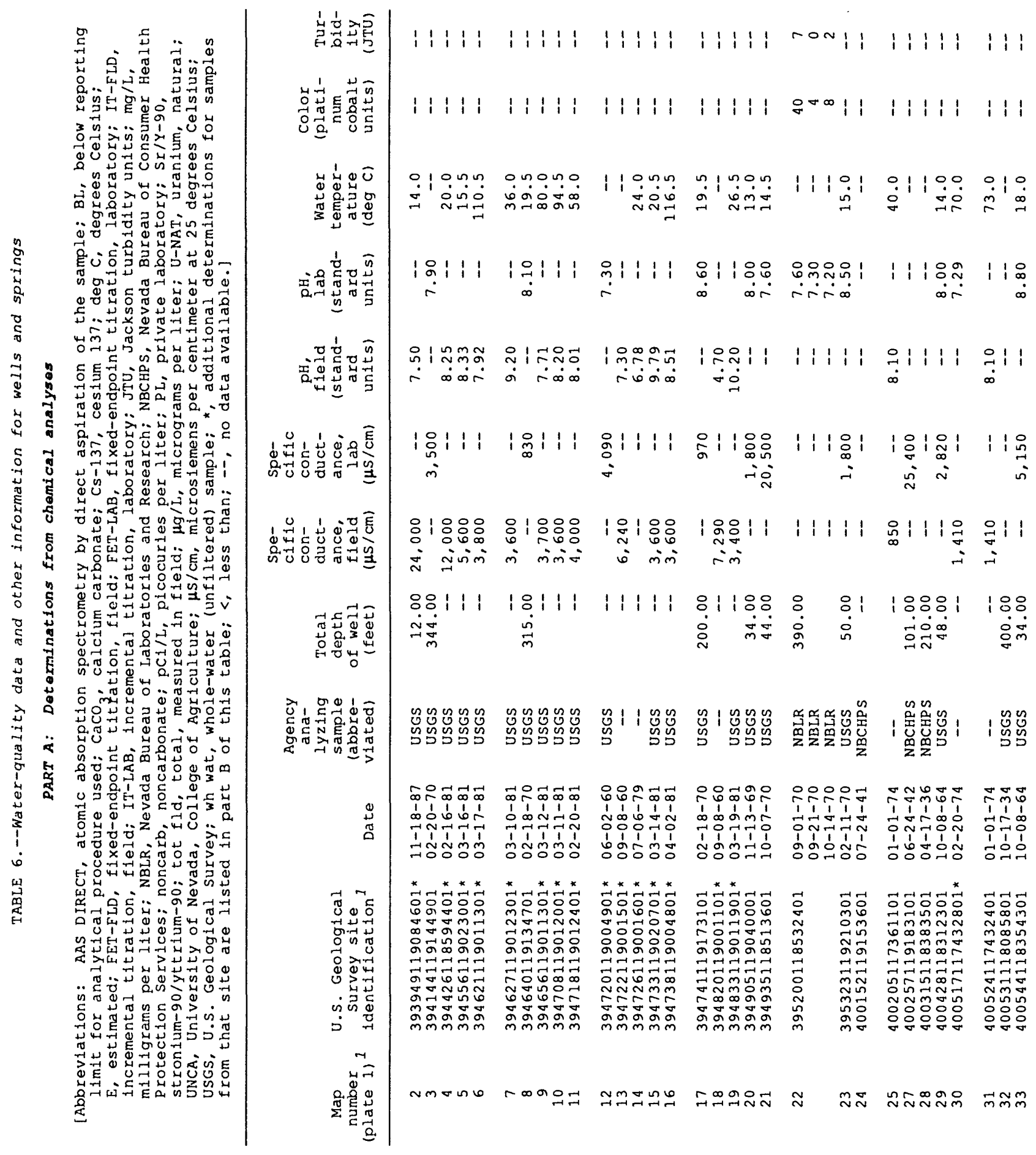




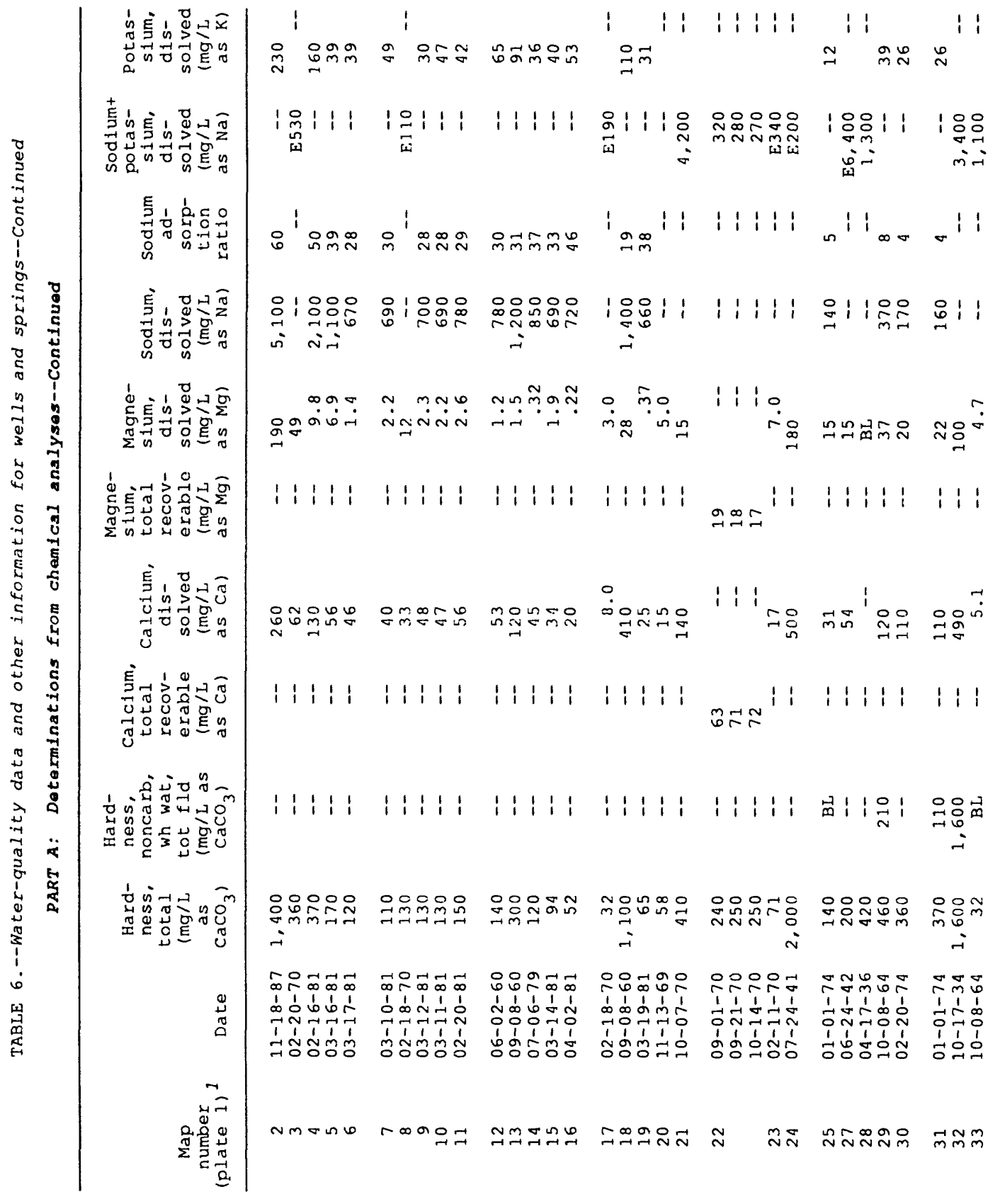




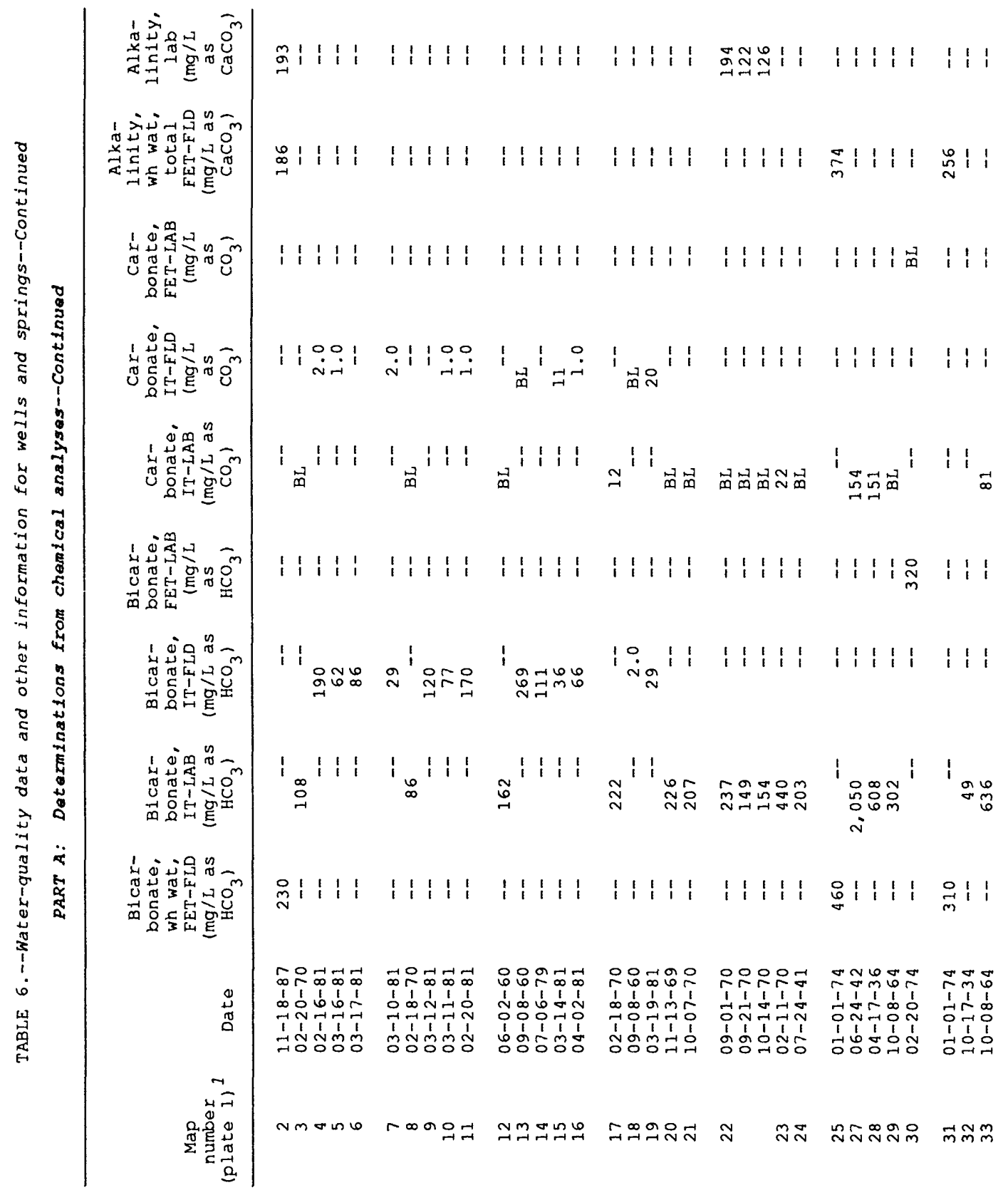




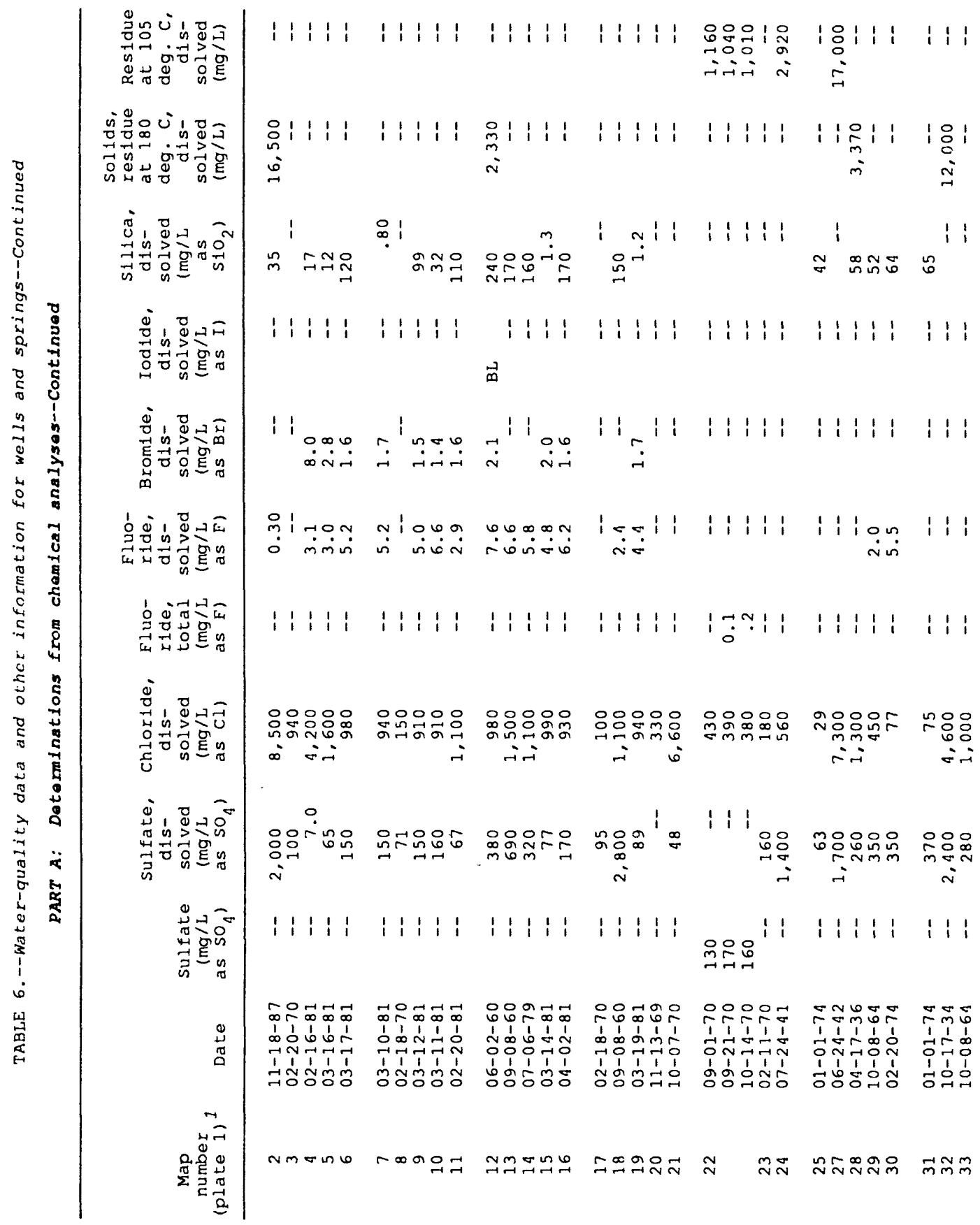




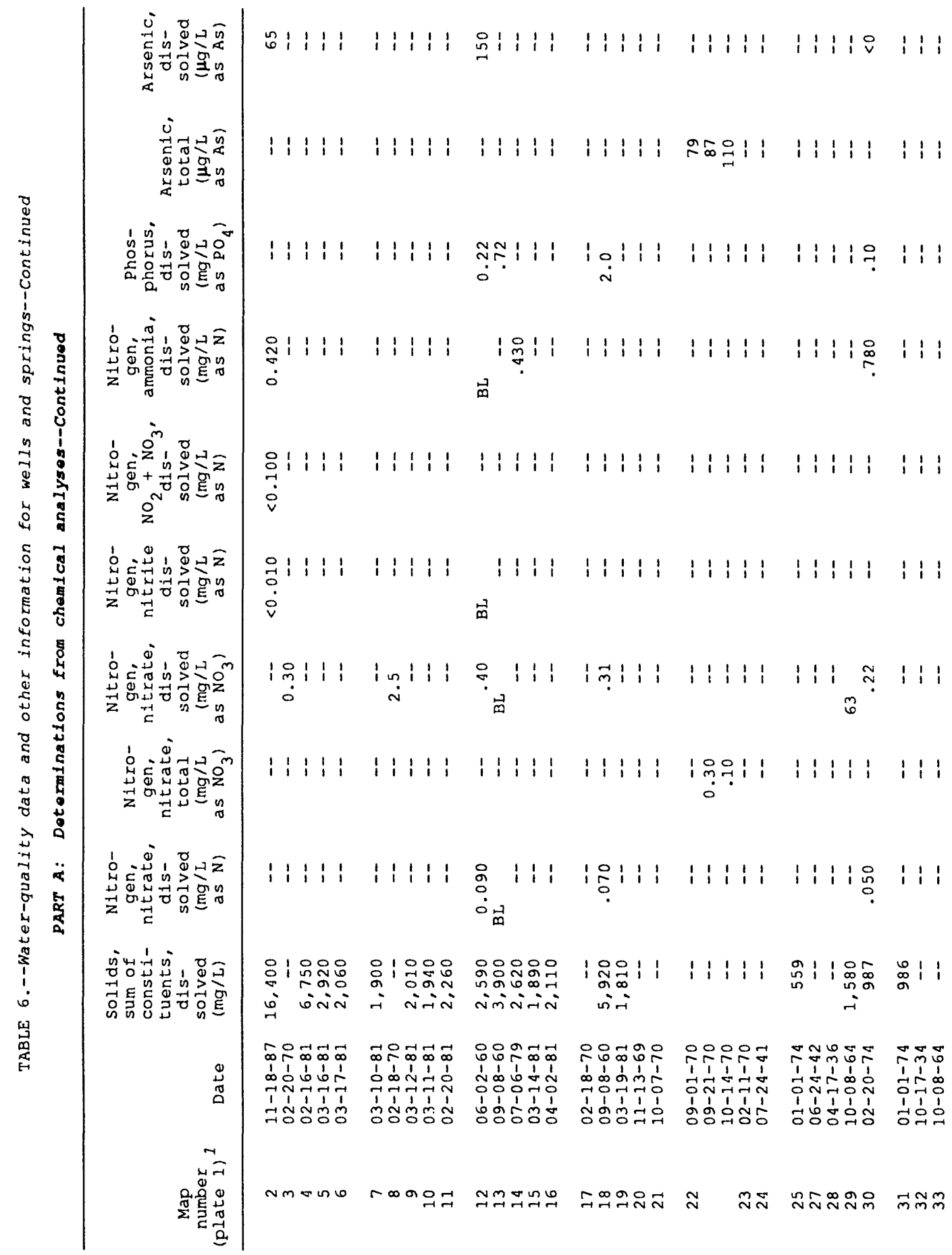




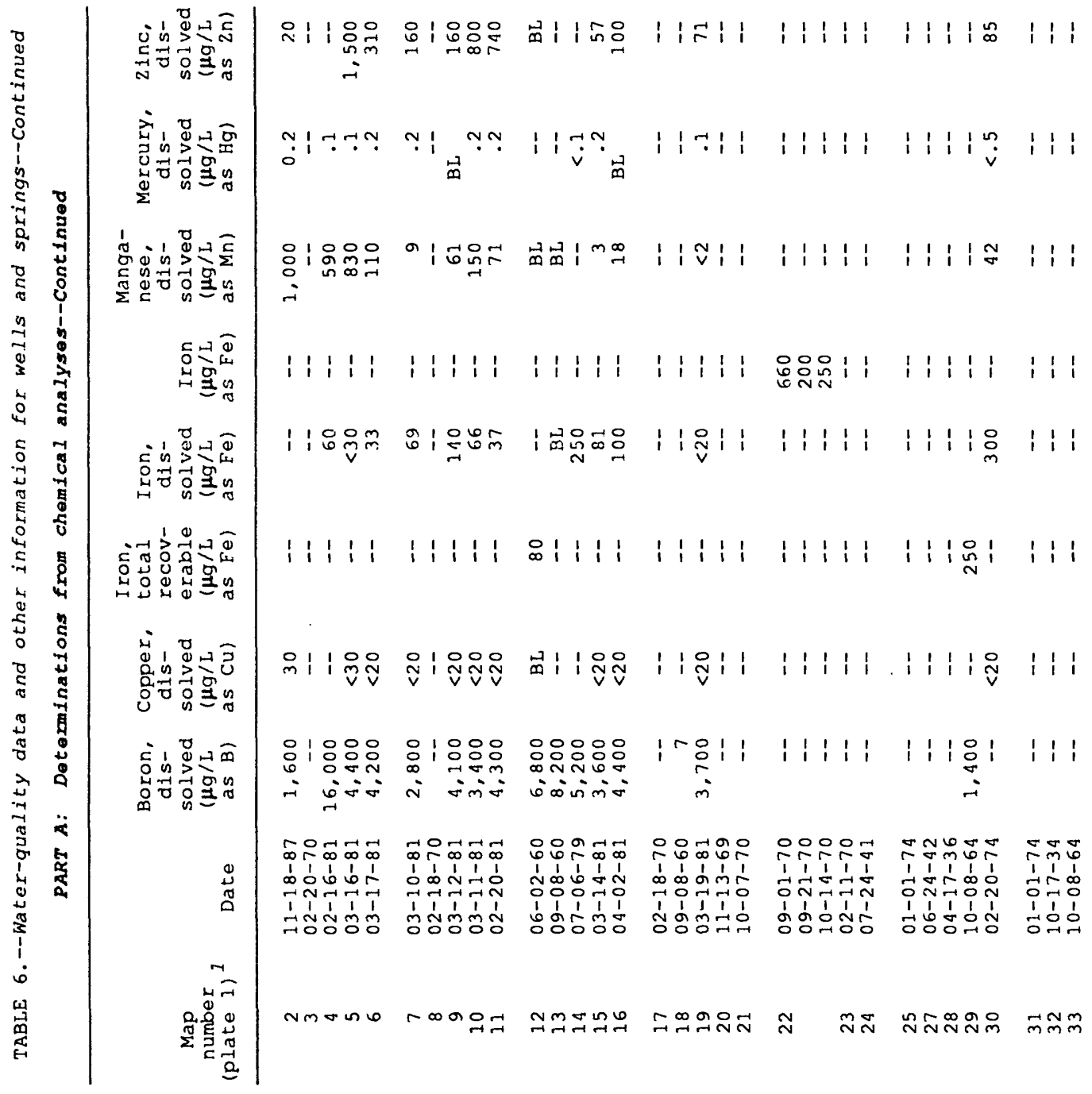




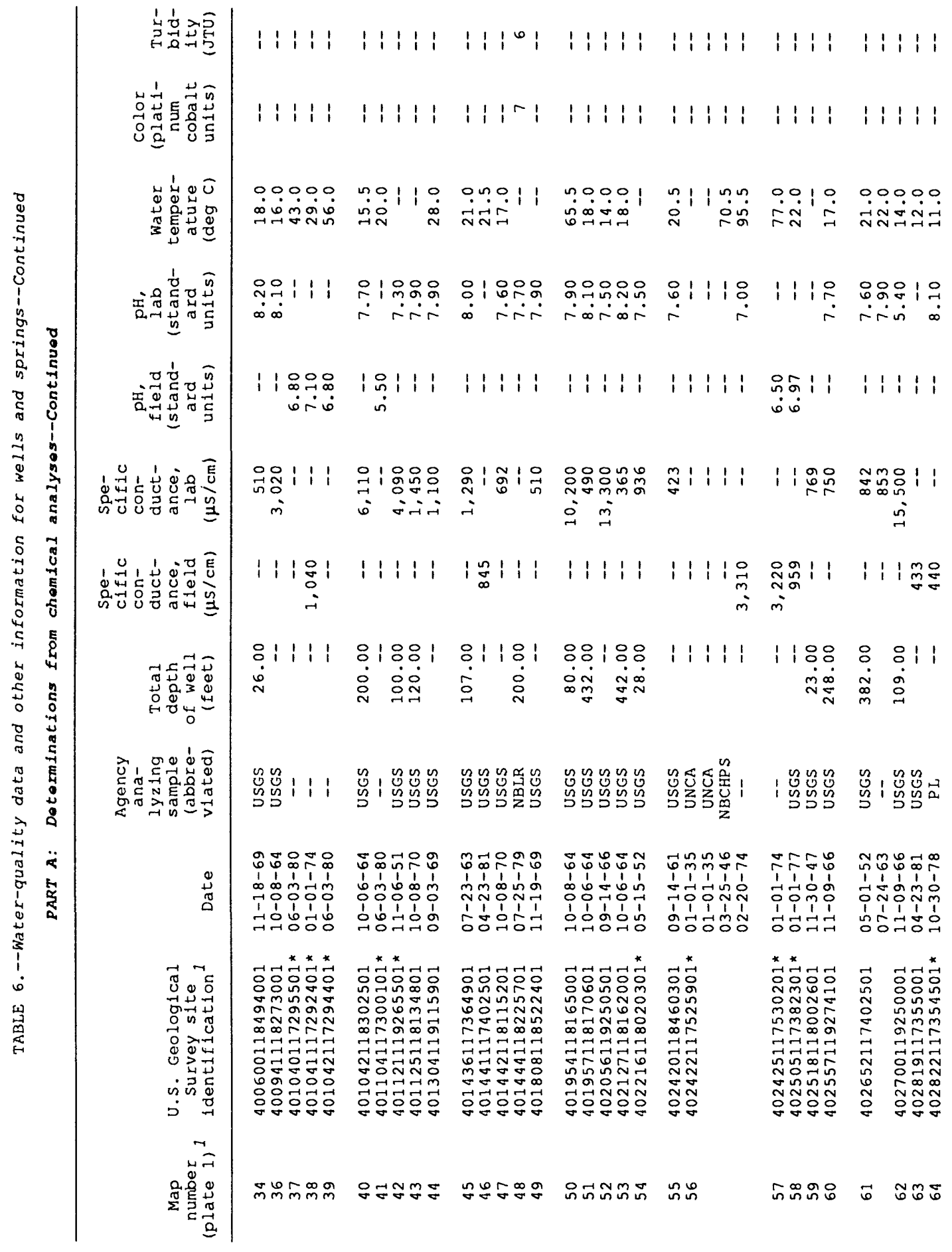




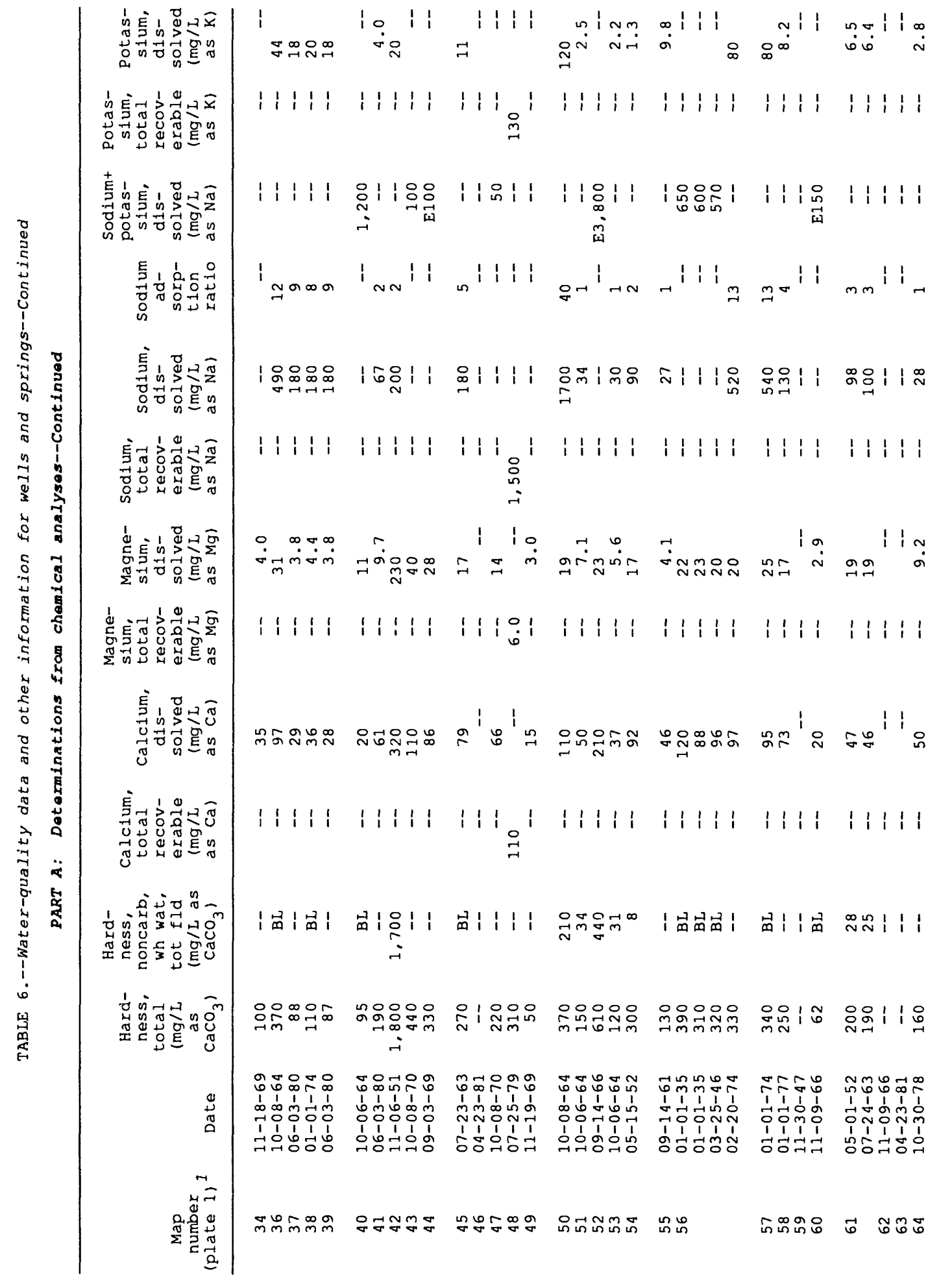




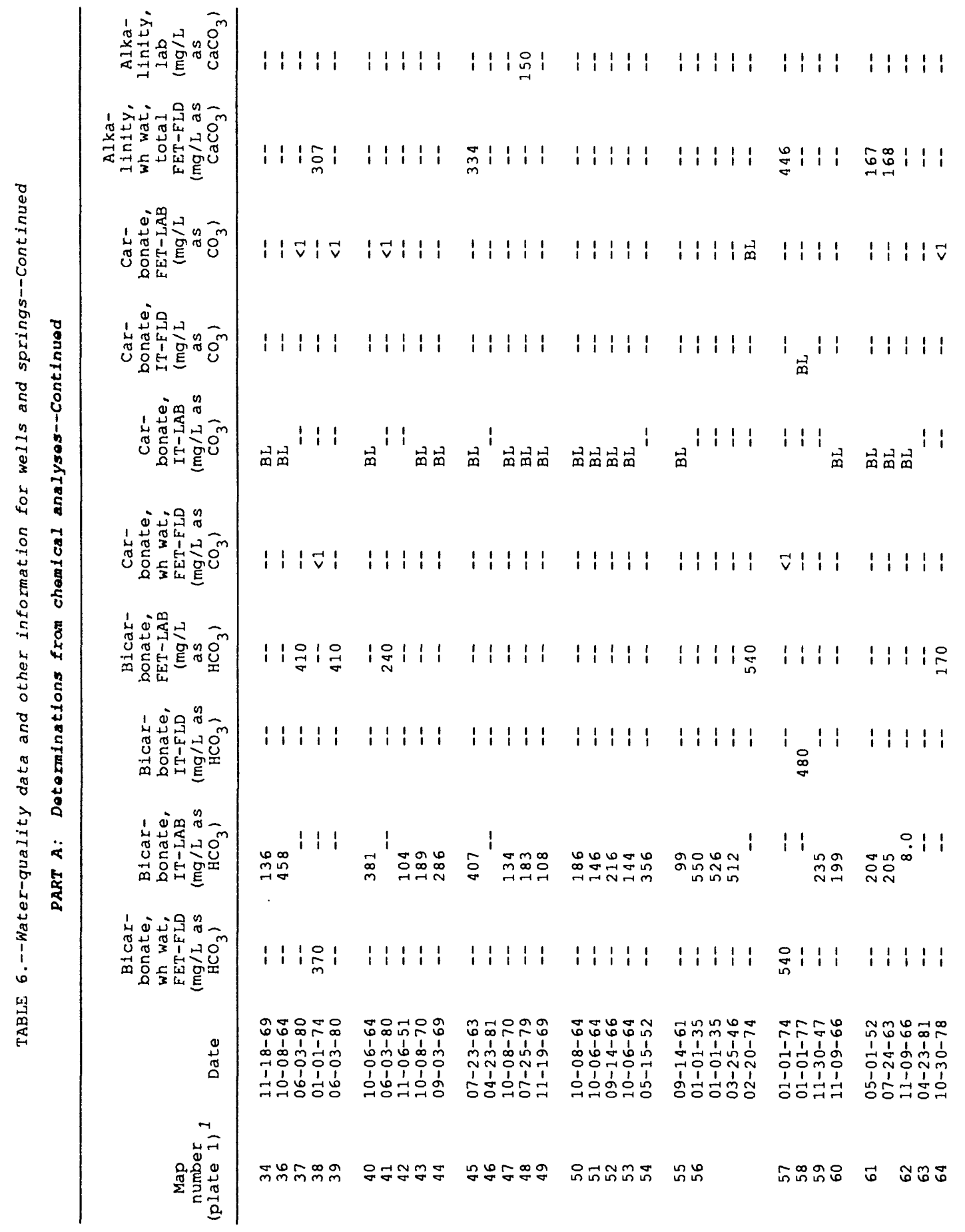




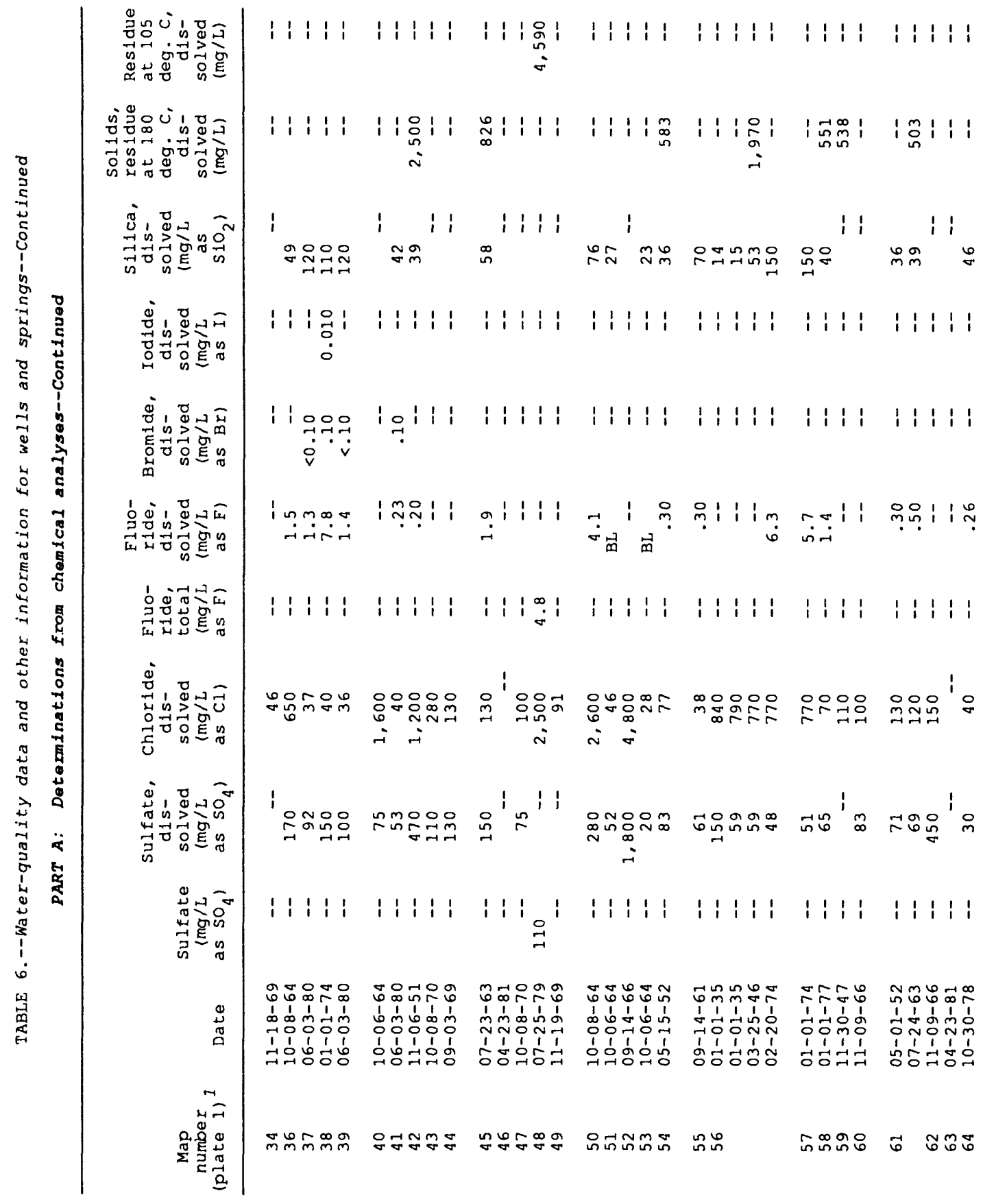




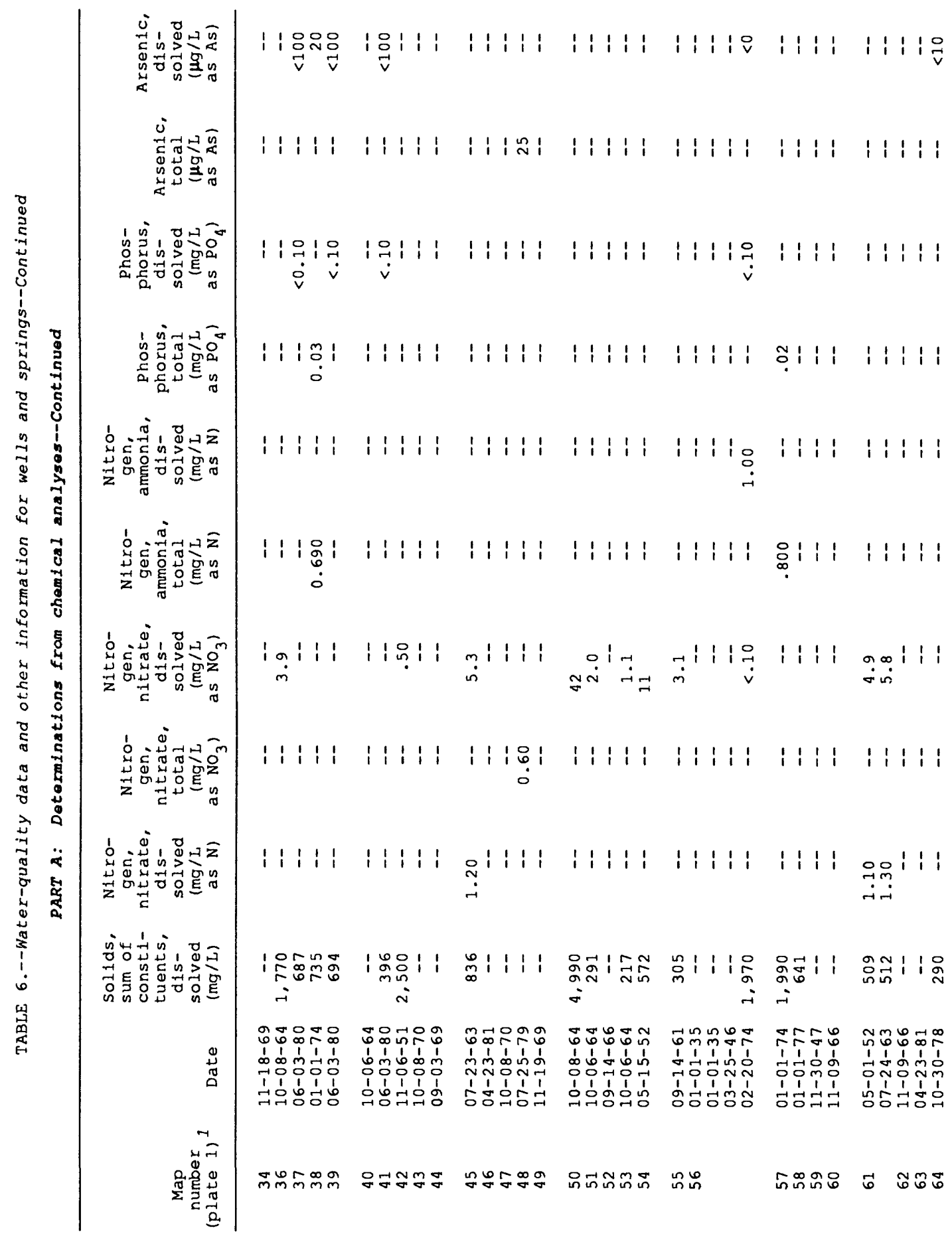




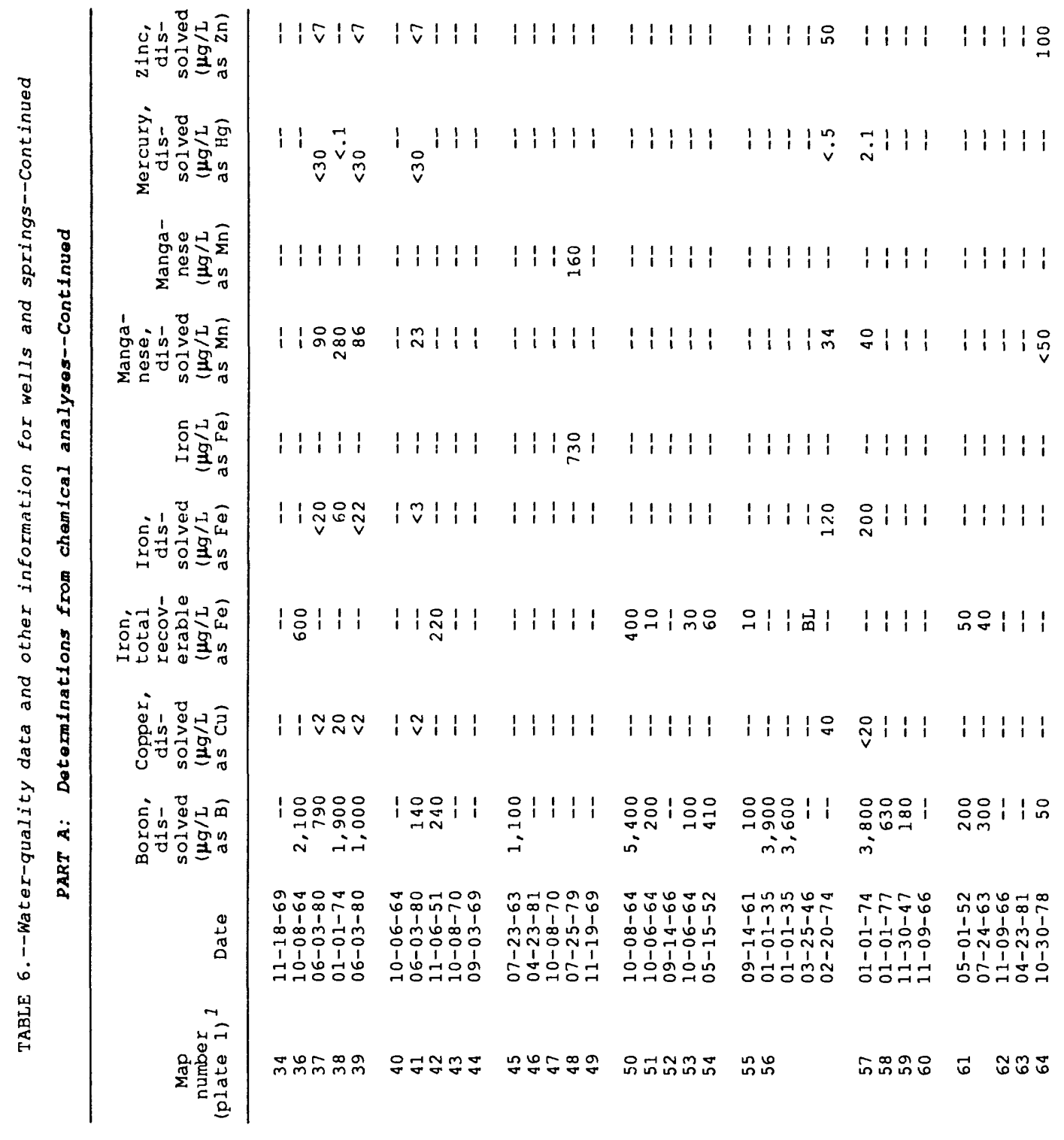




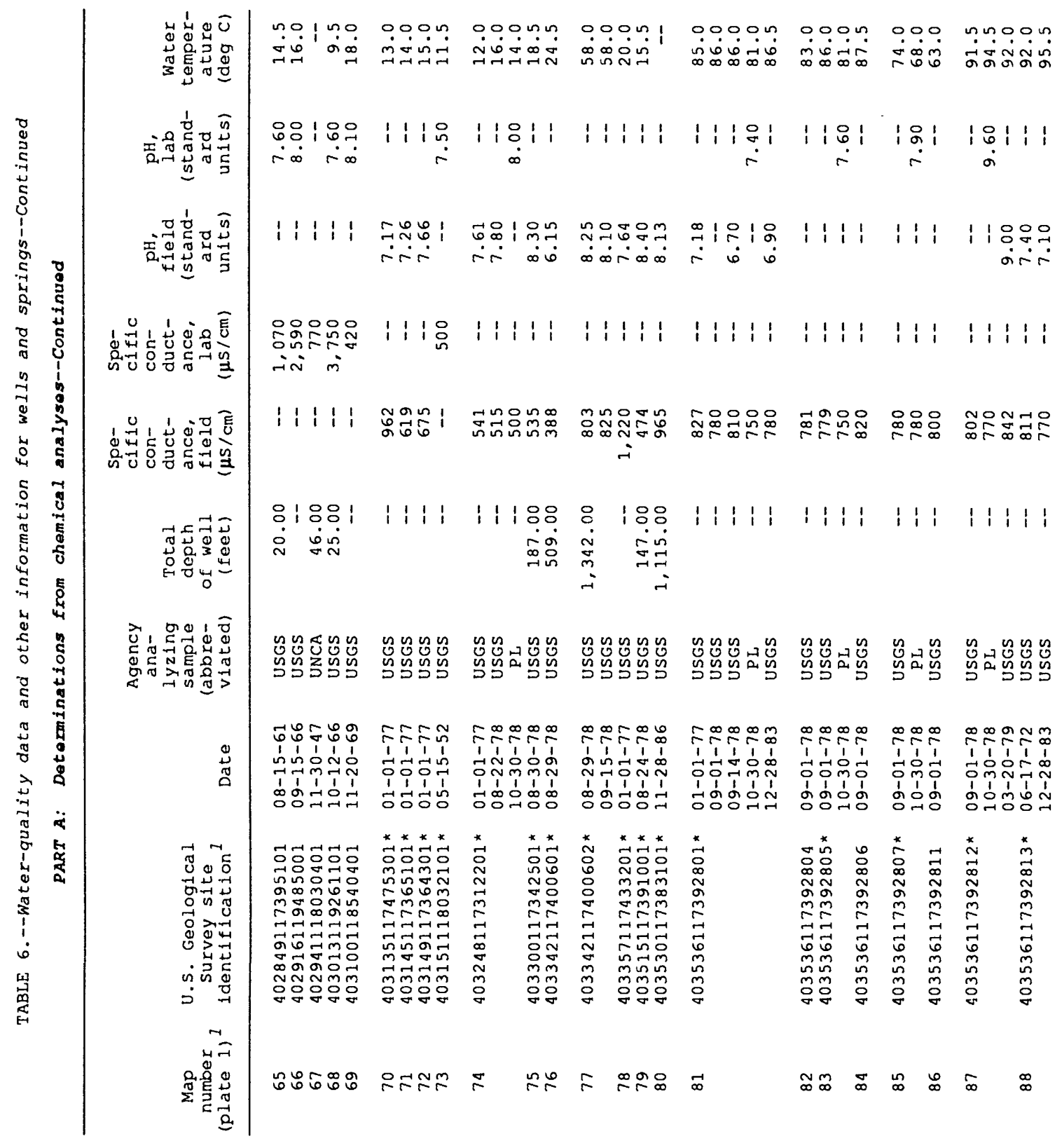




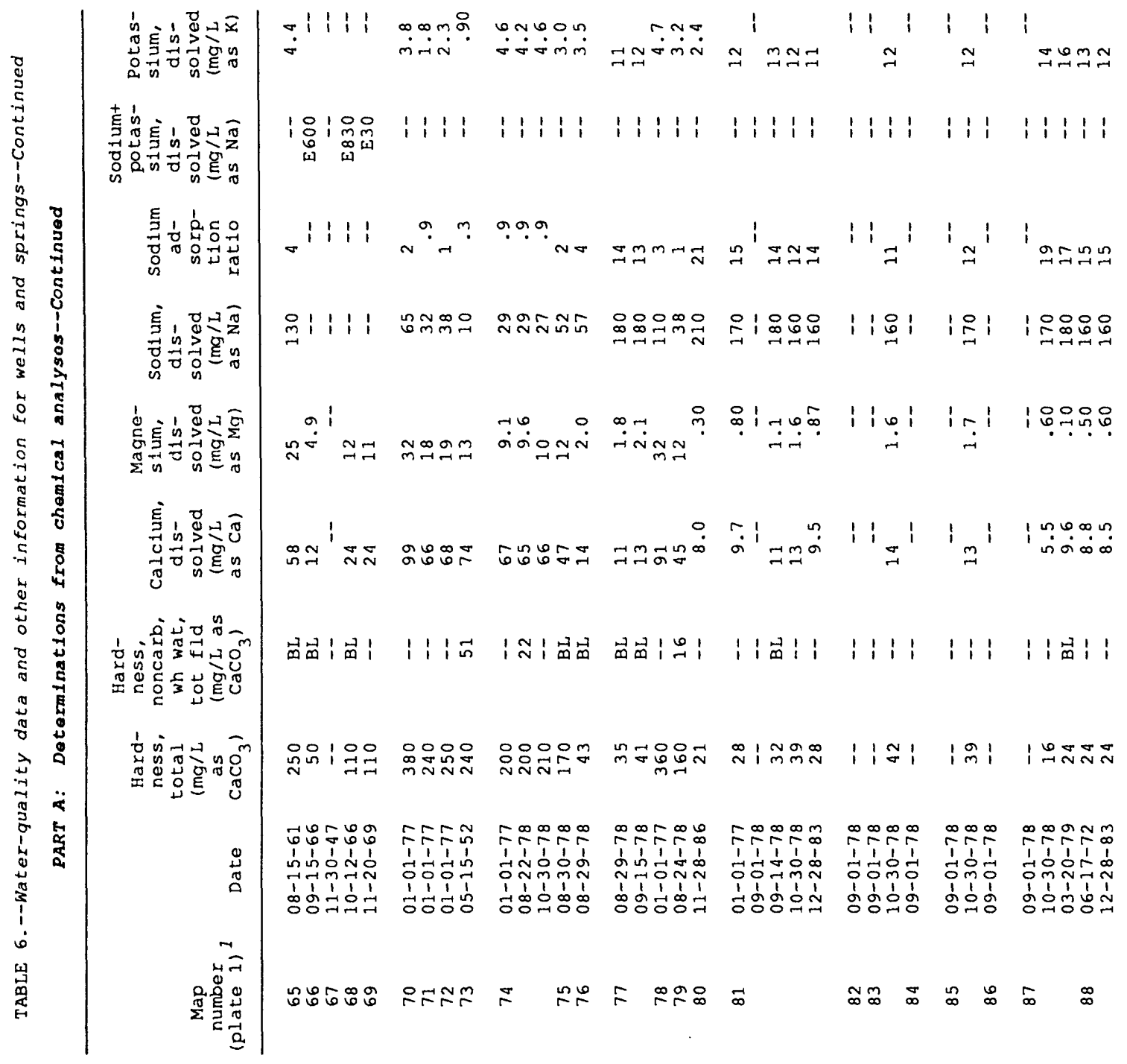




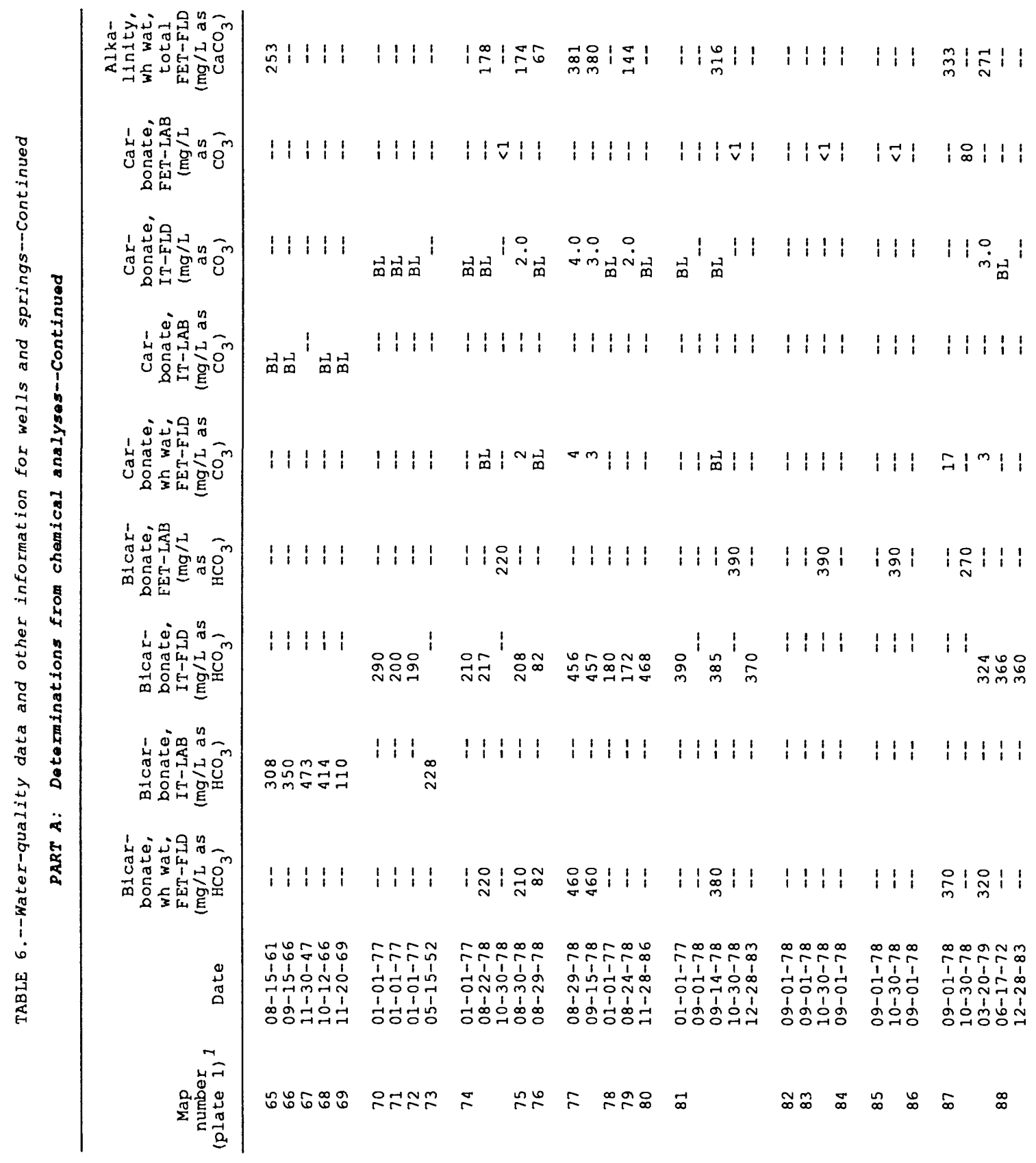




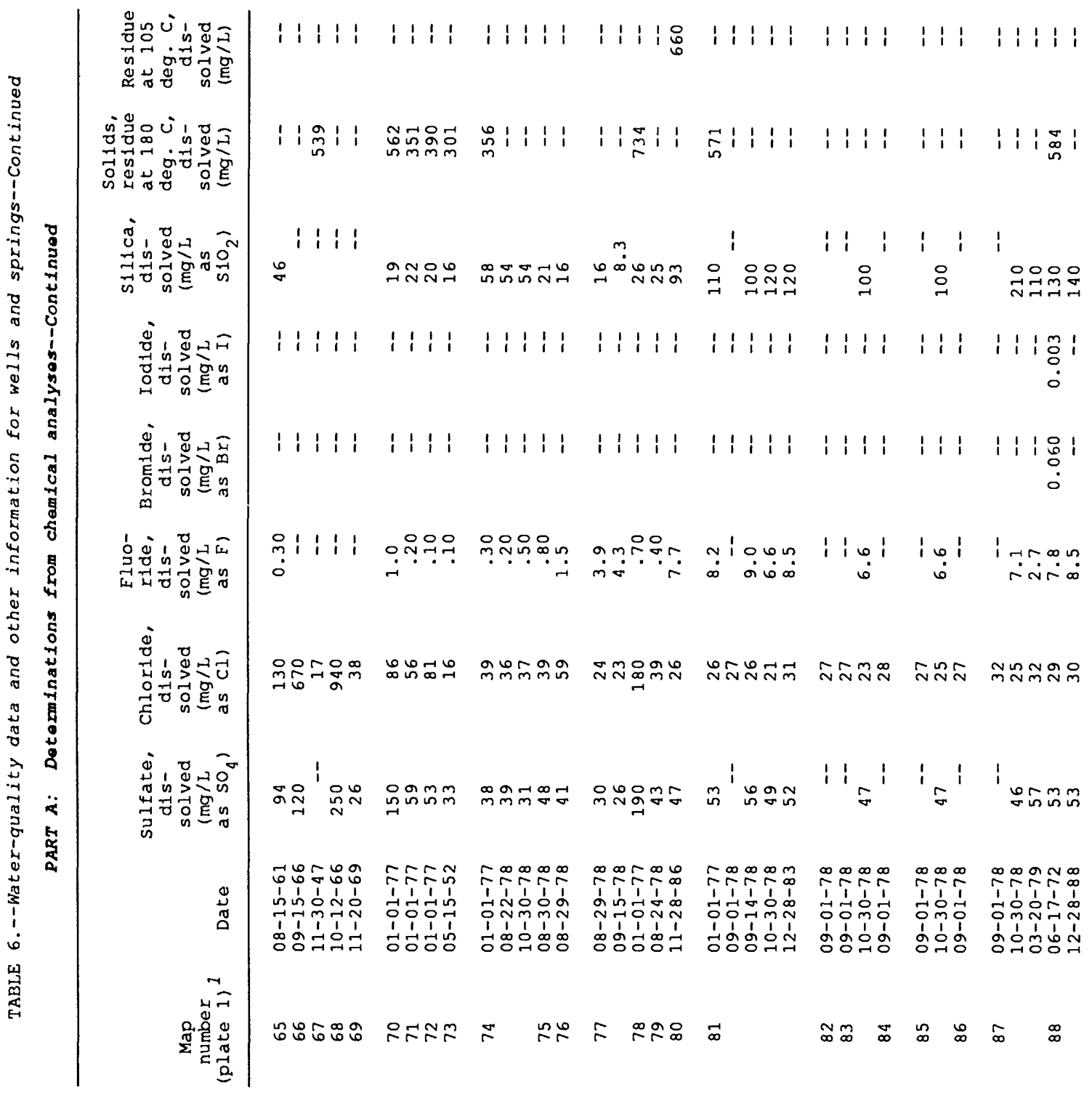




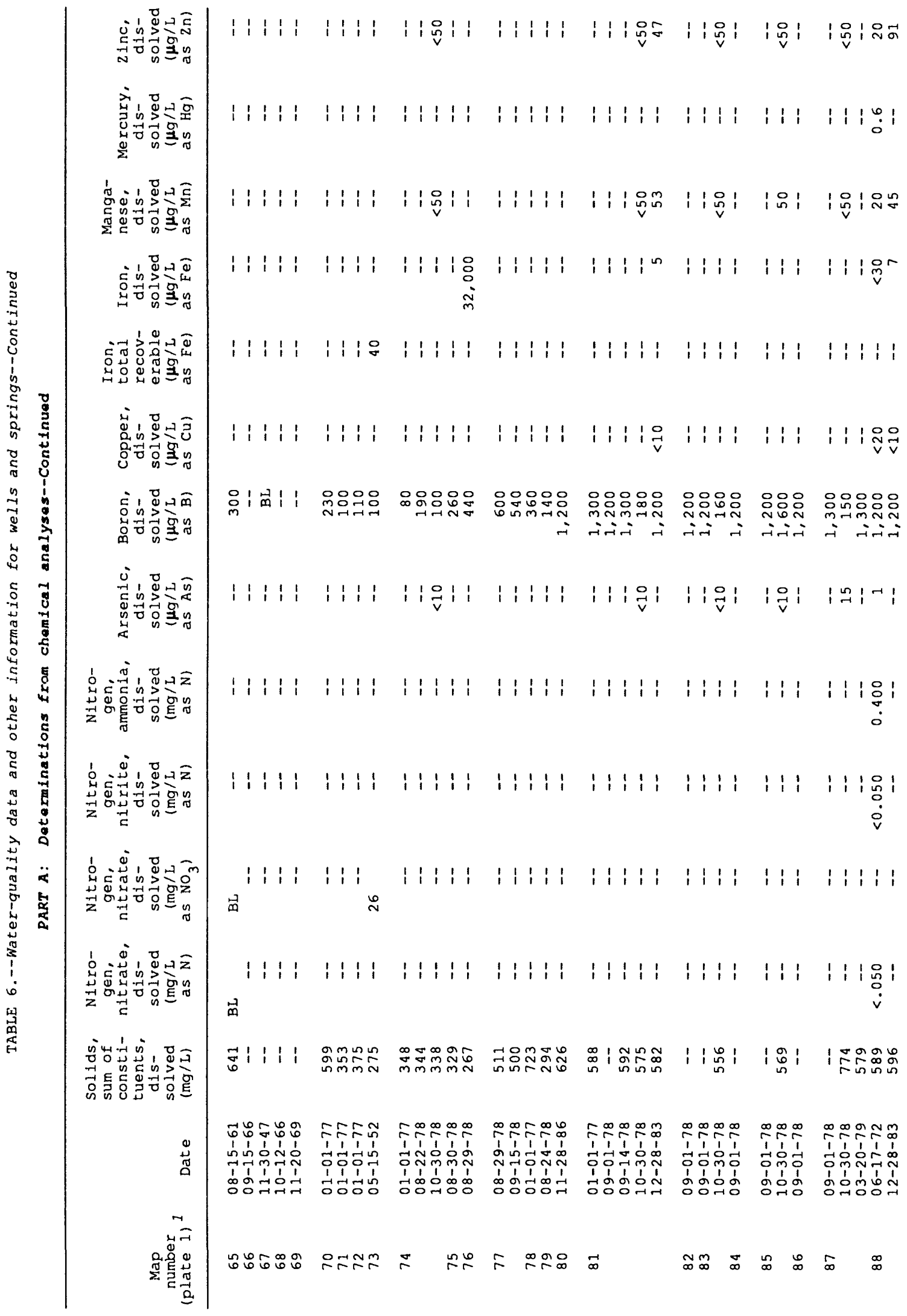




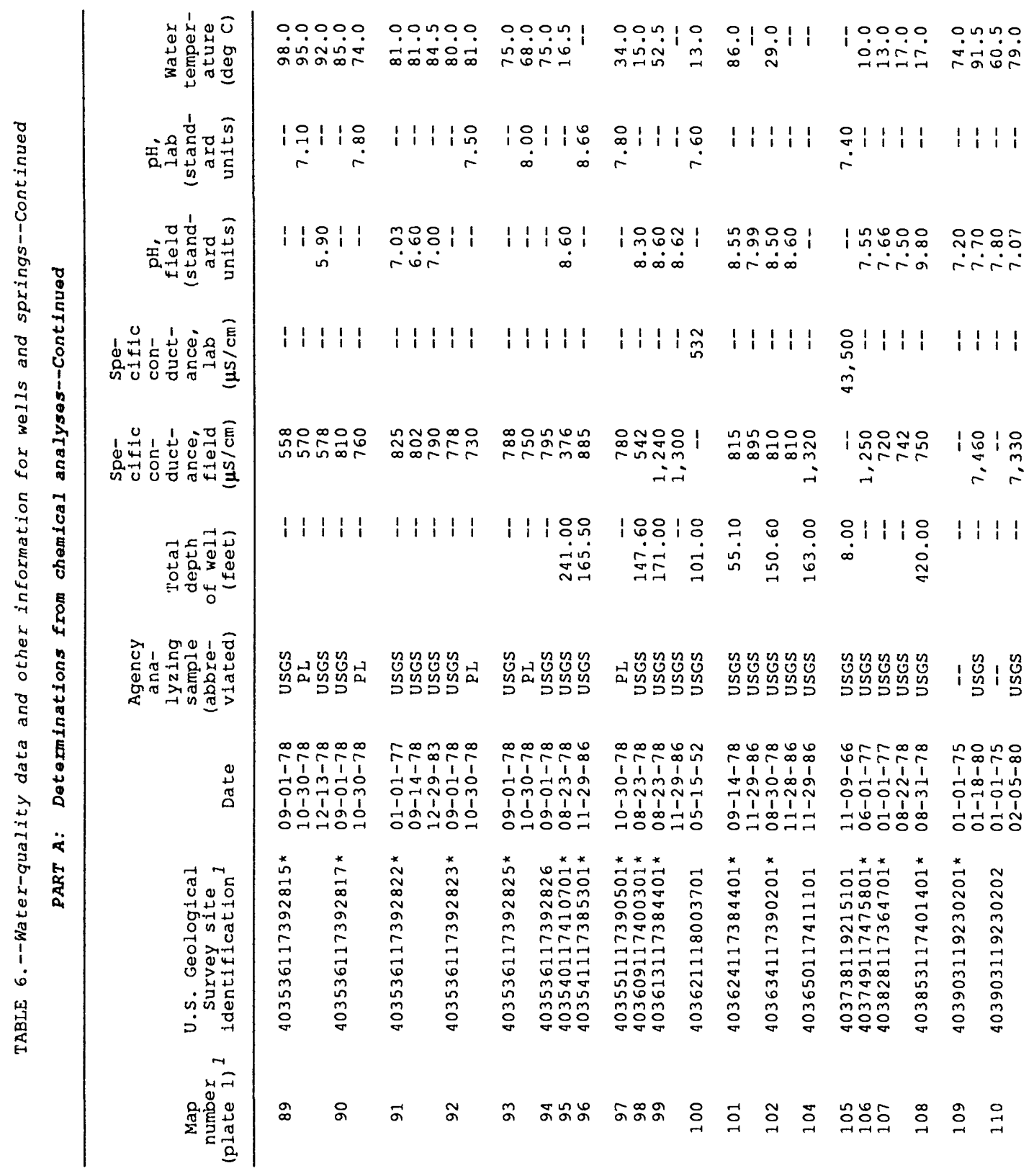




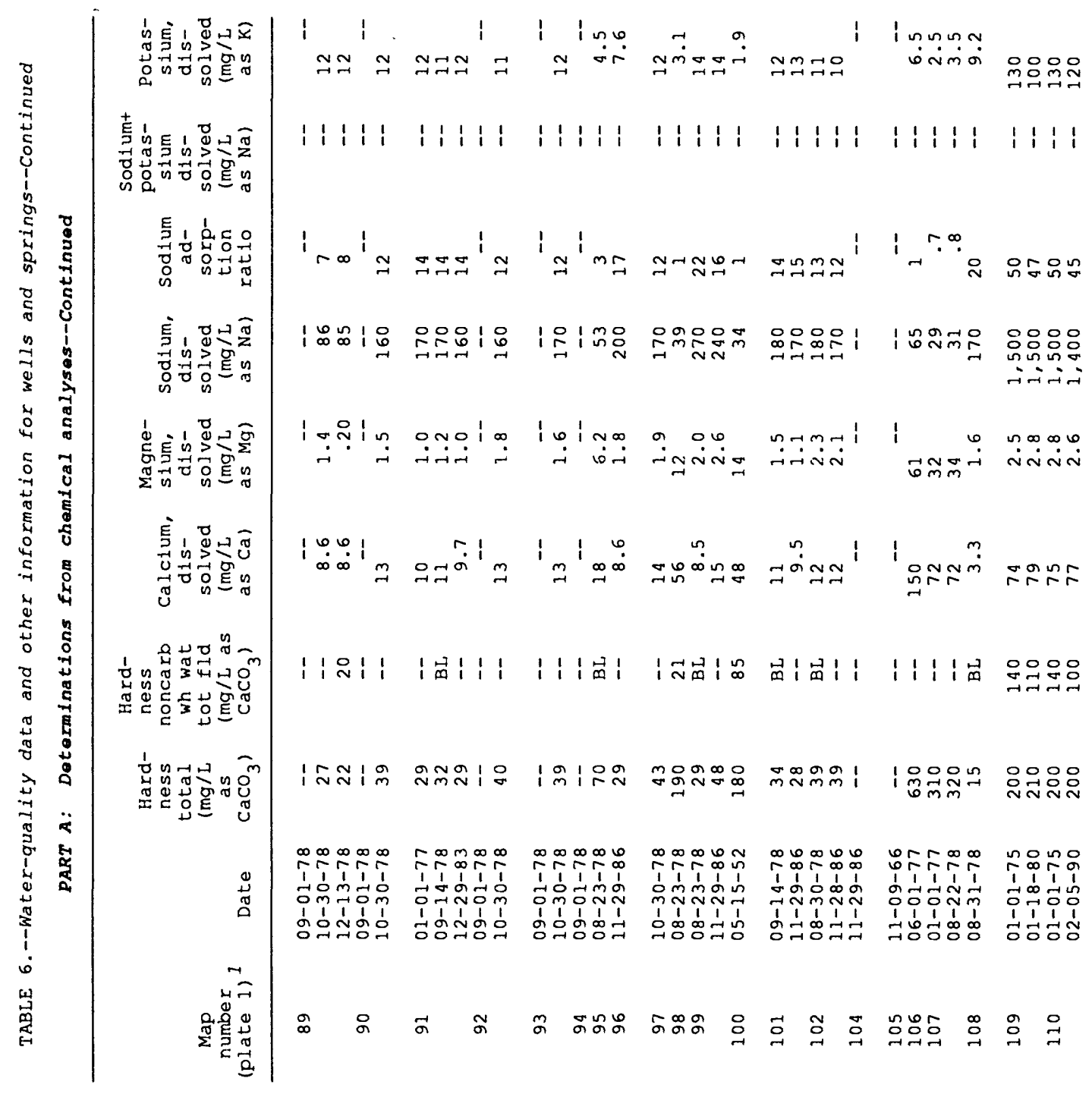




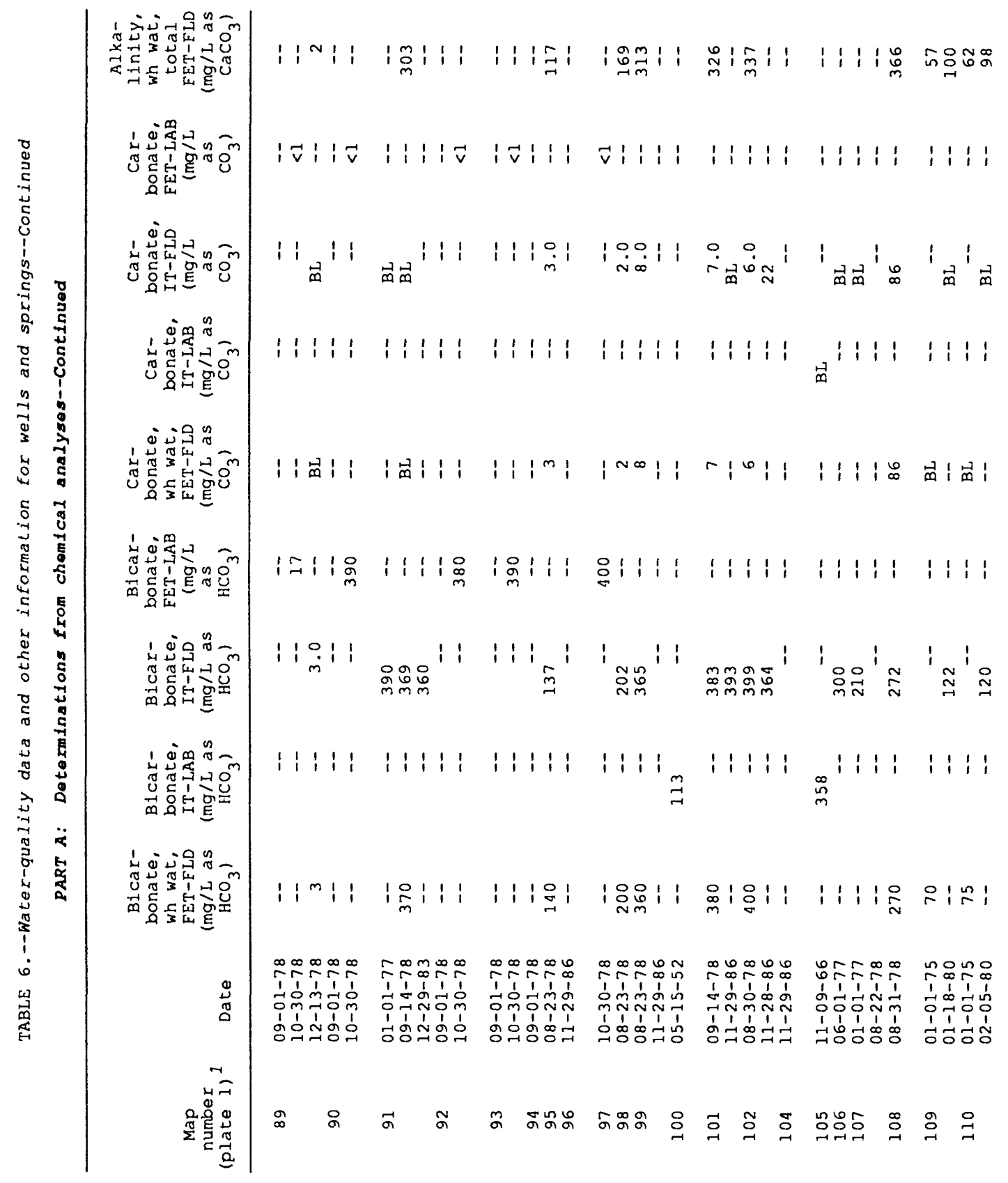




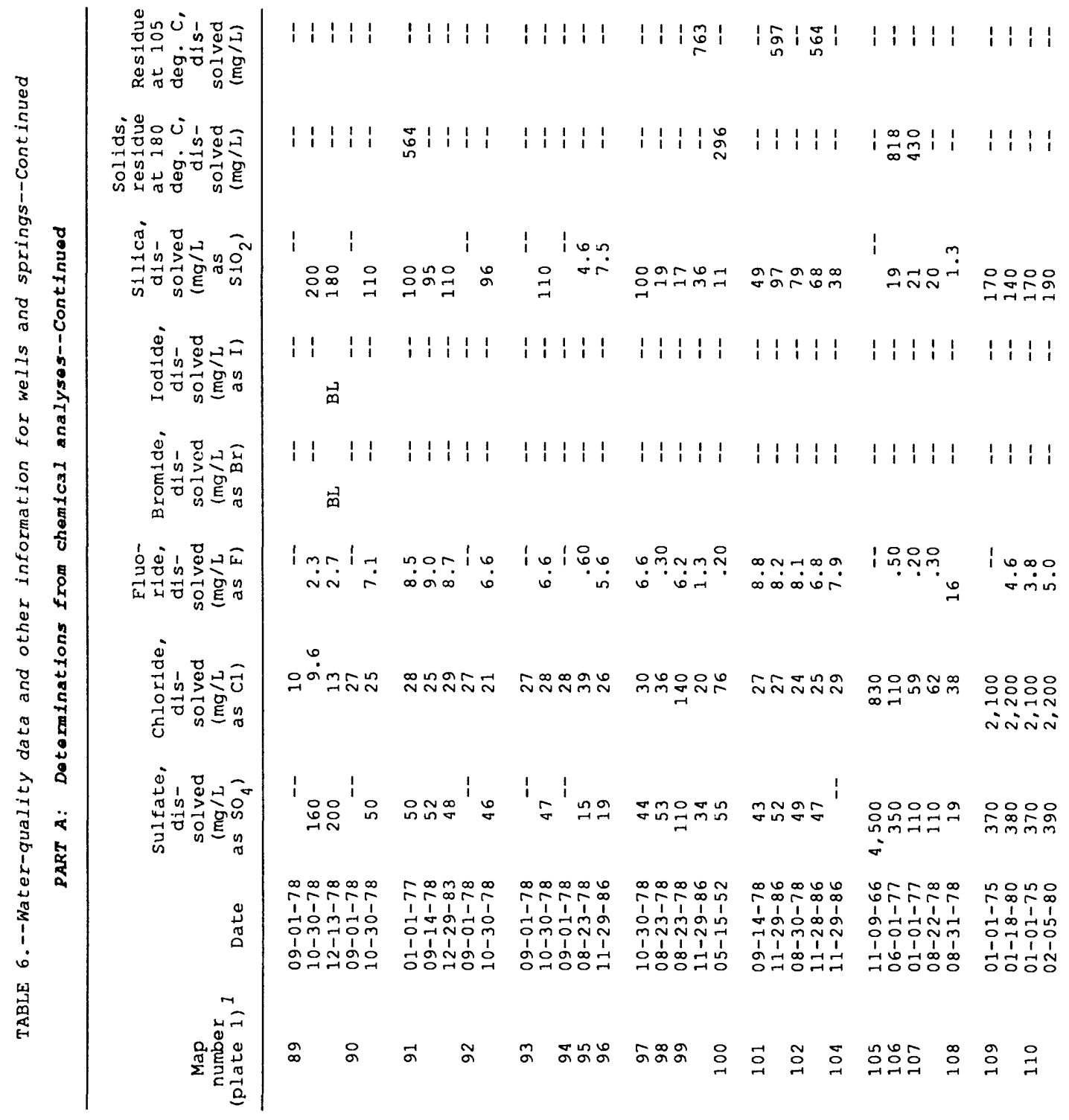




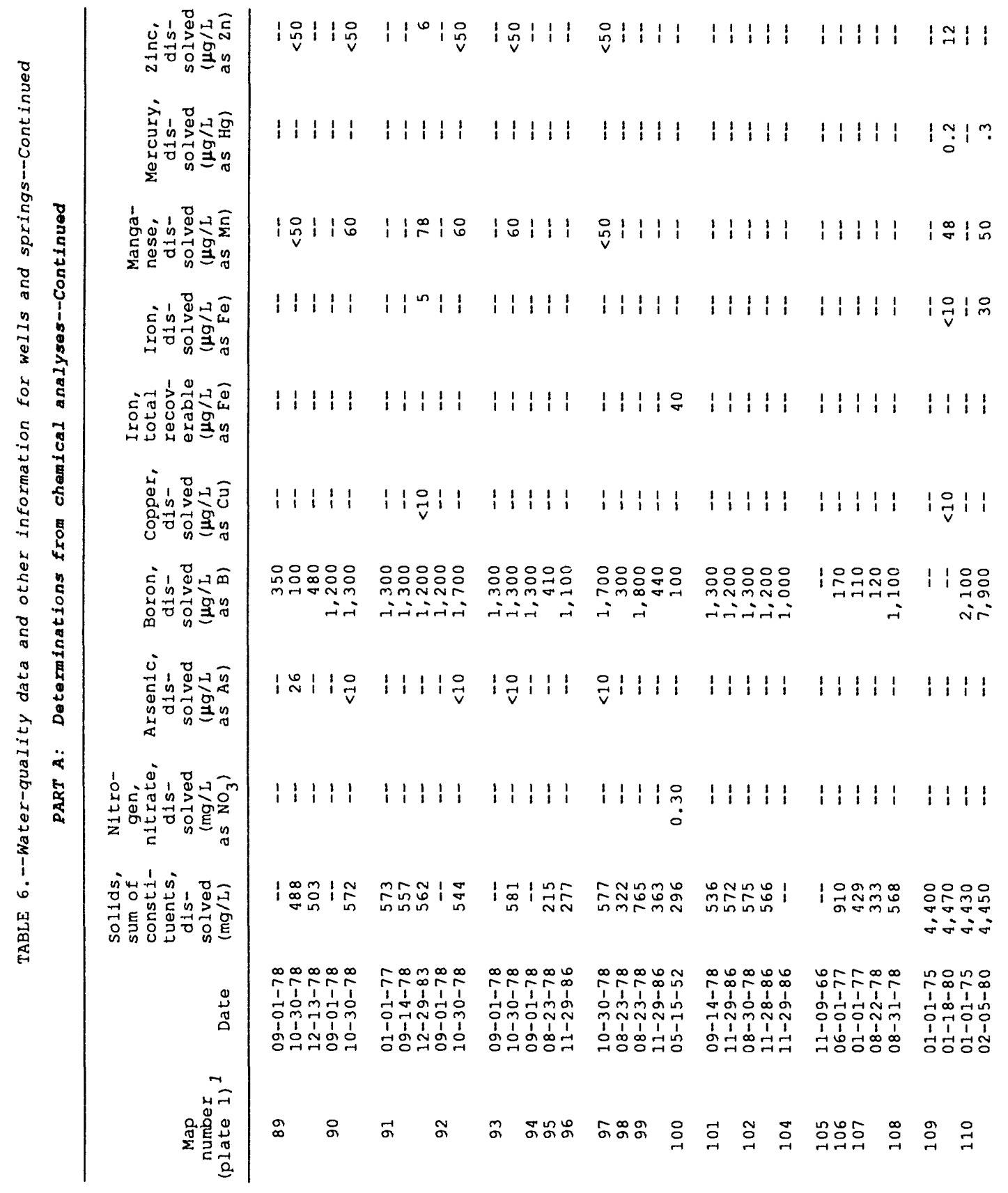




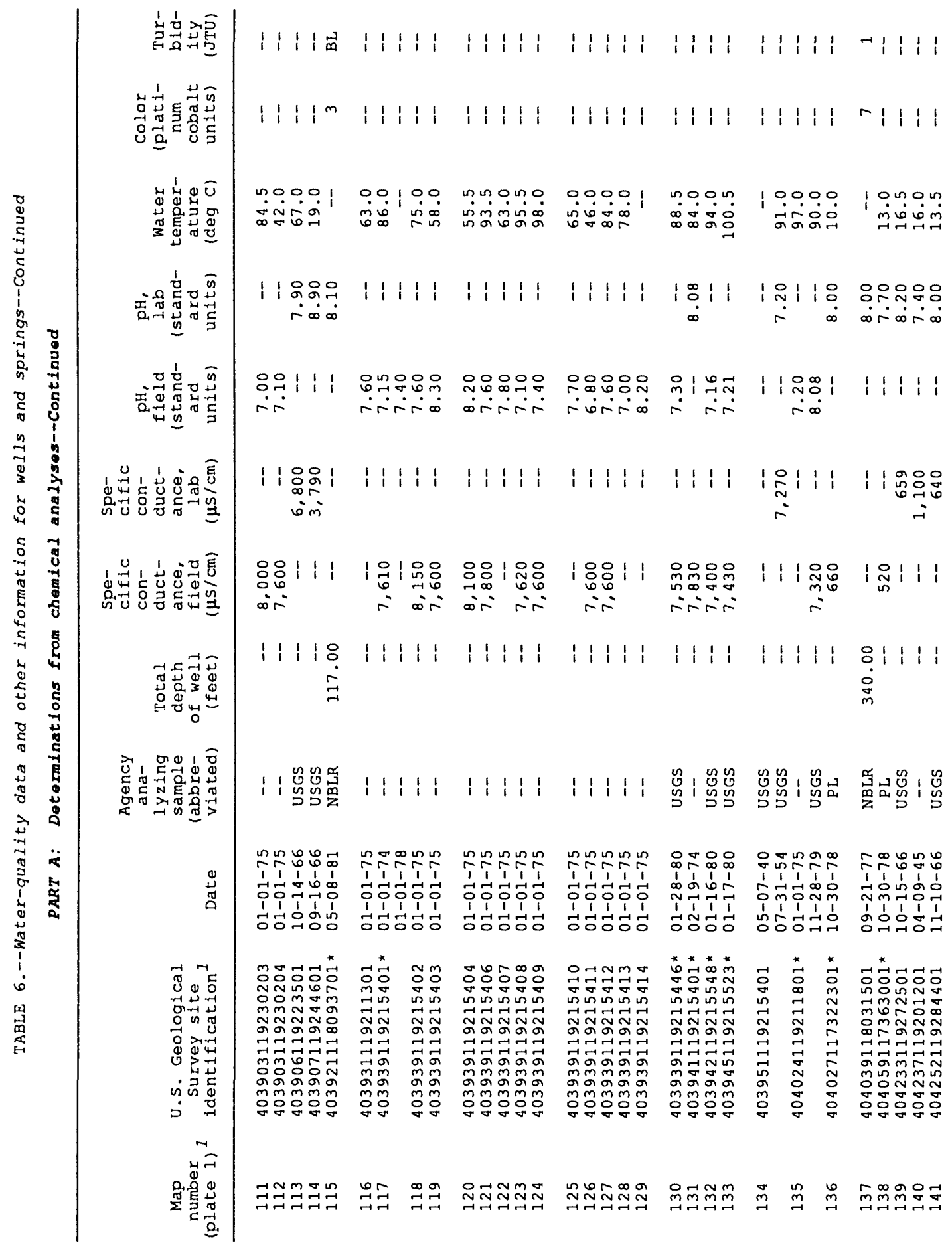




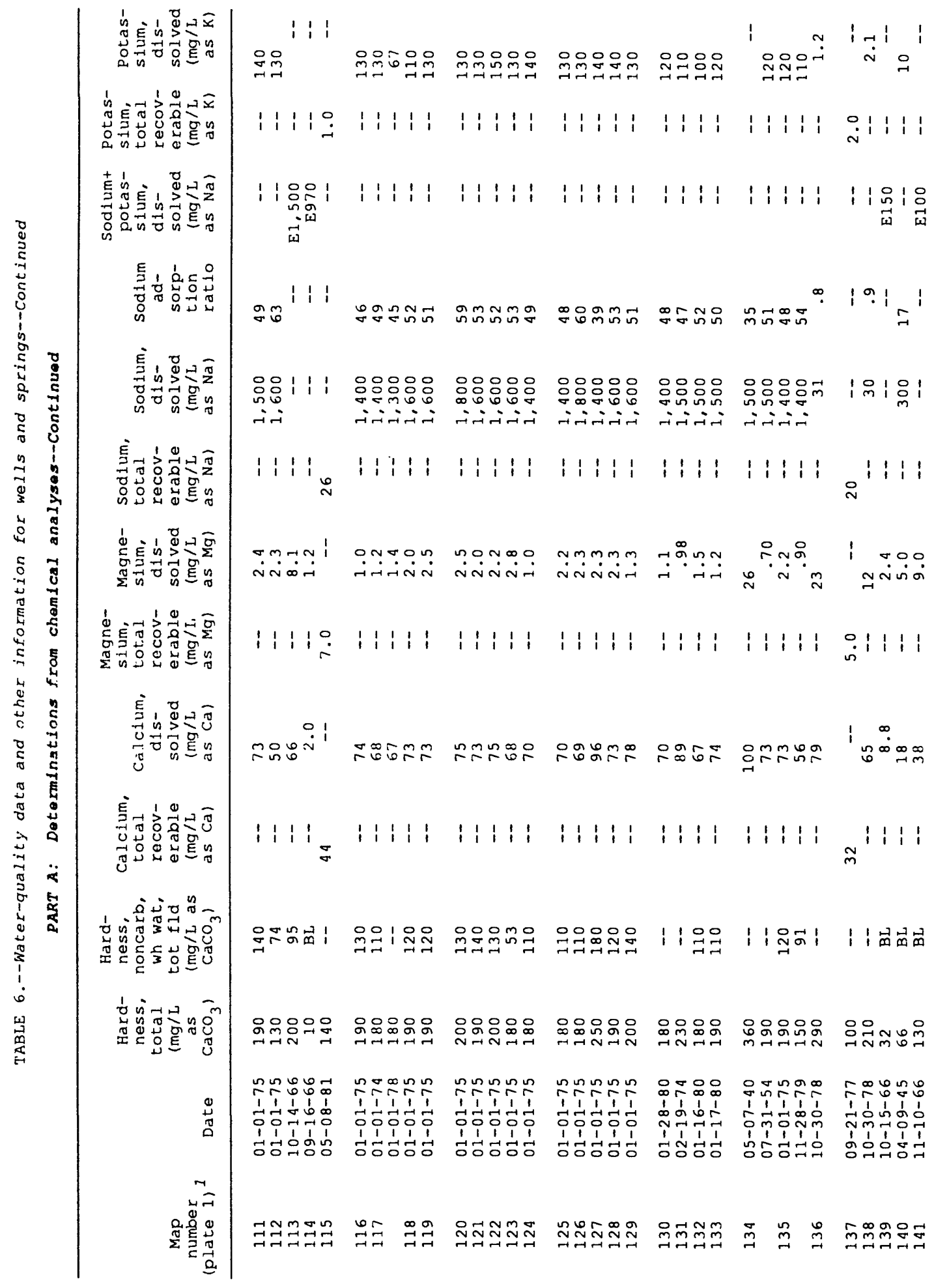




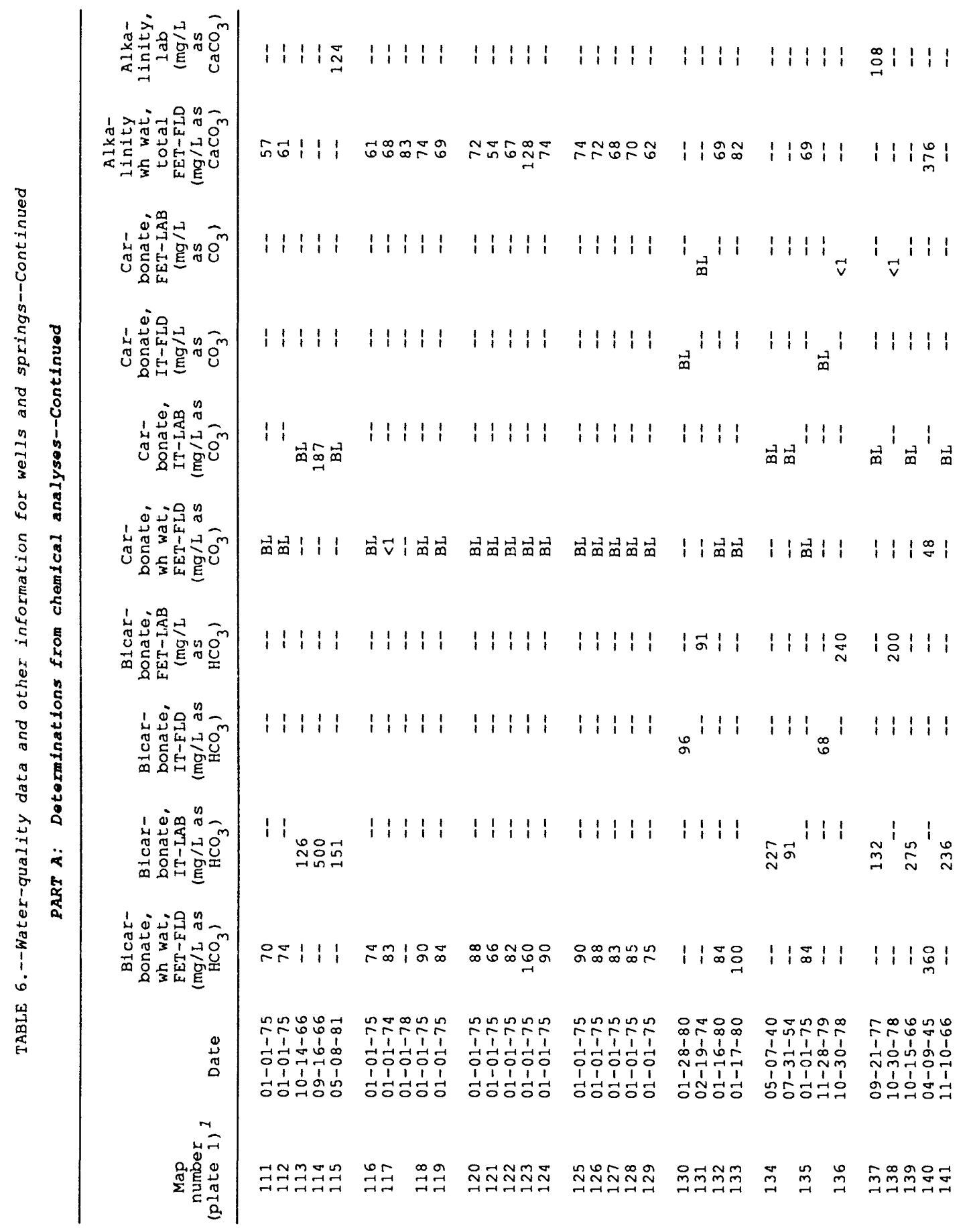




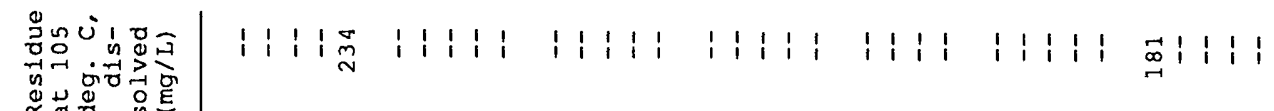

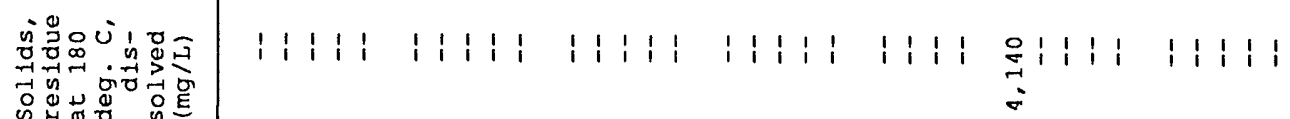

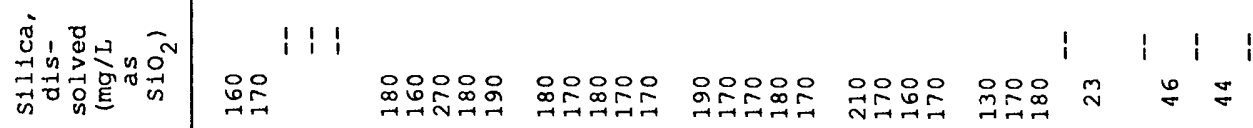

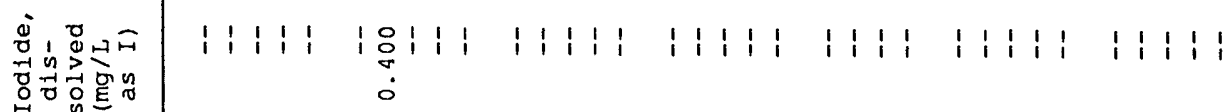

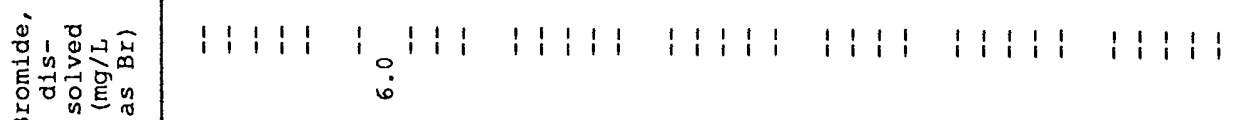

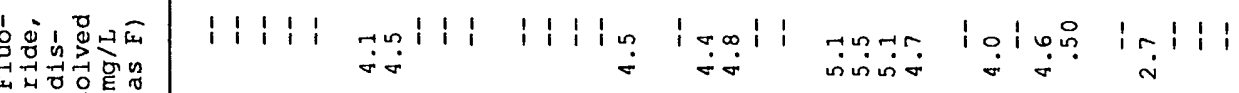

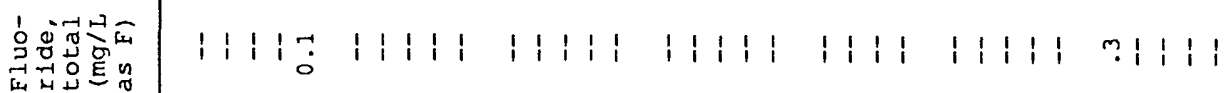

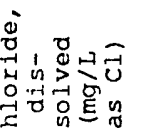

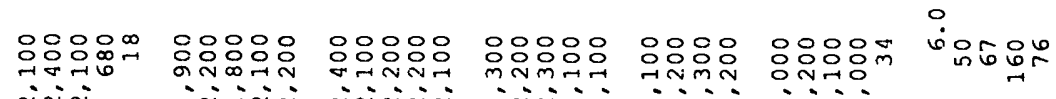

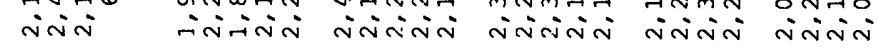
要券

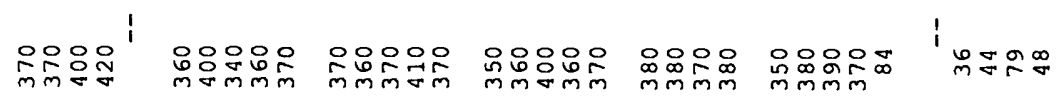

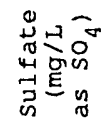

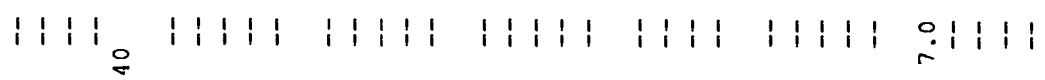

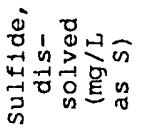

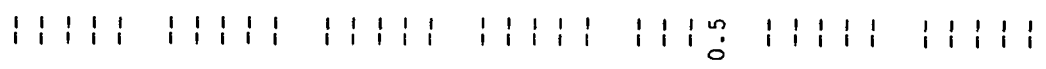

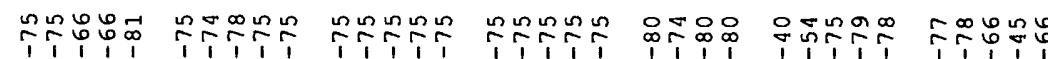

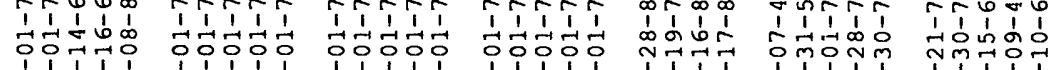

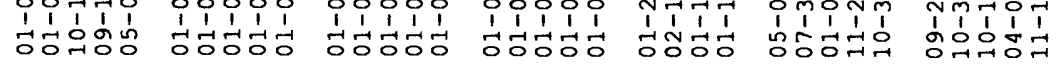

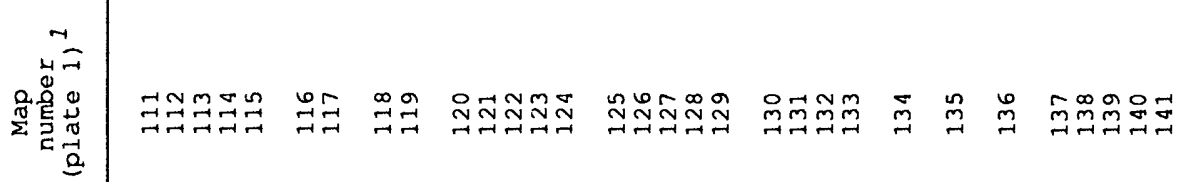




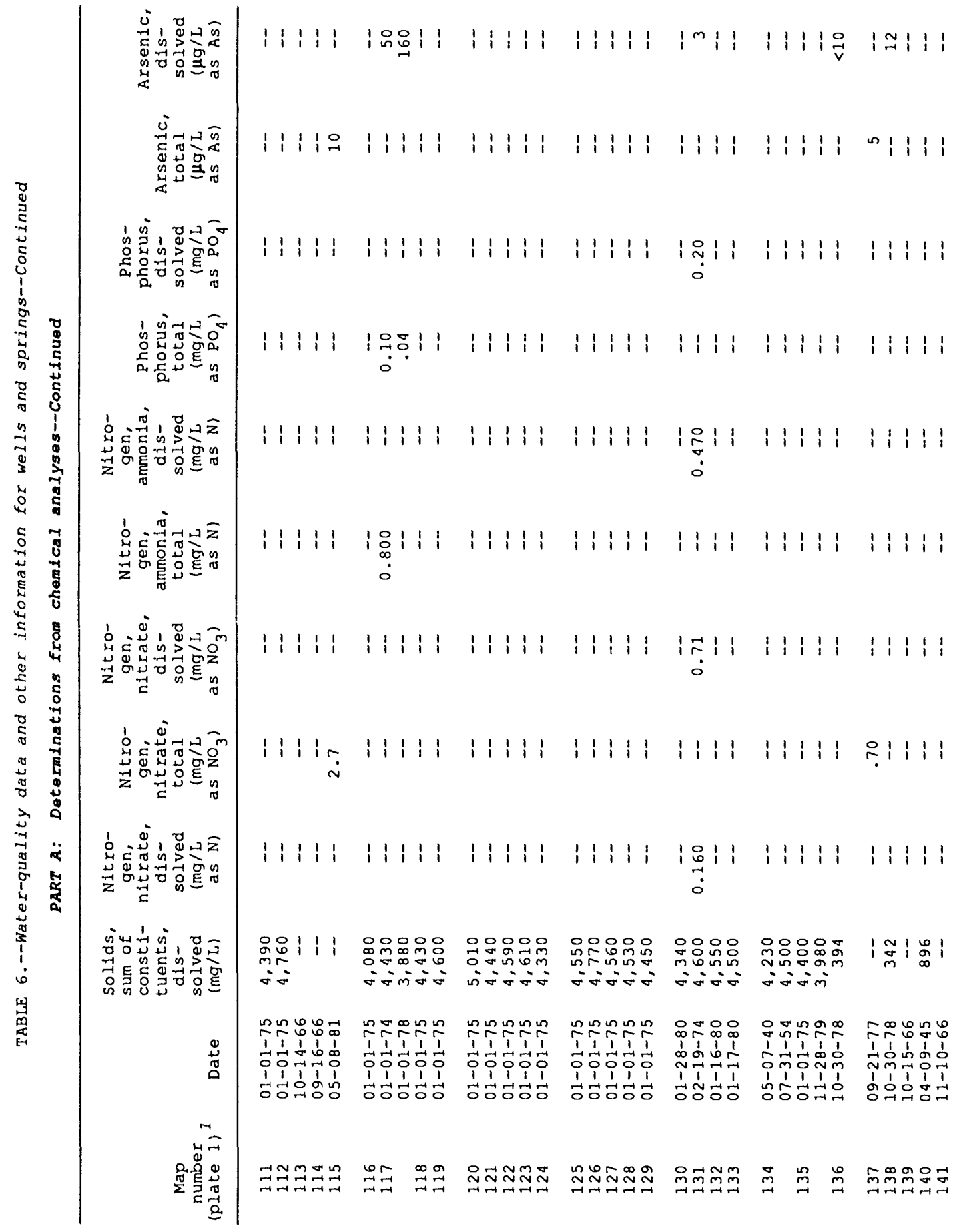




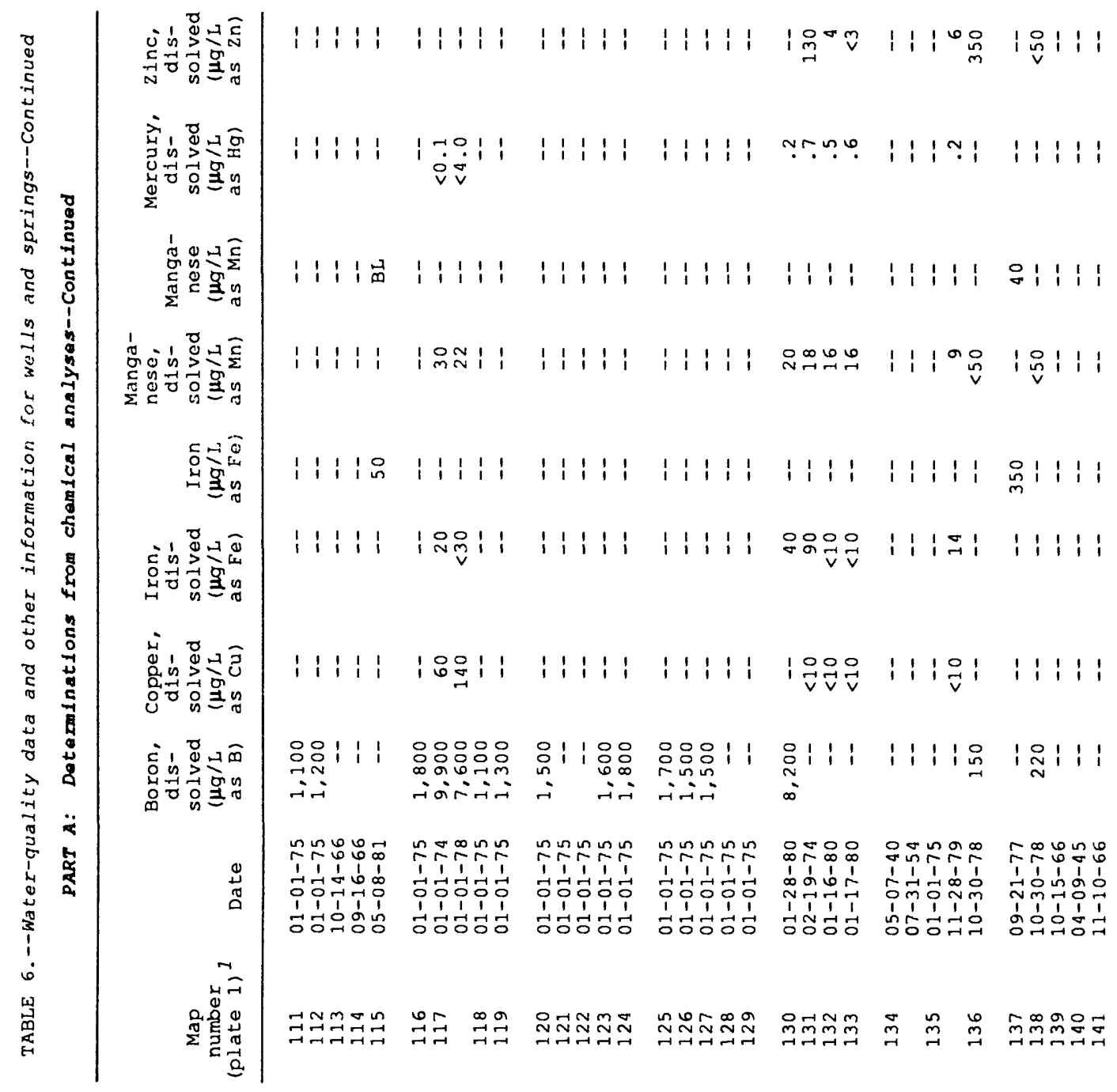




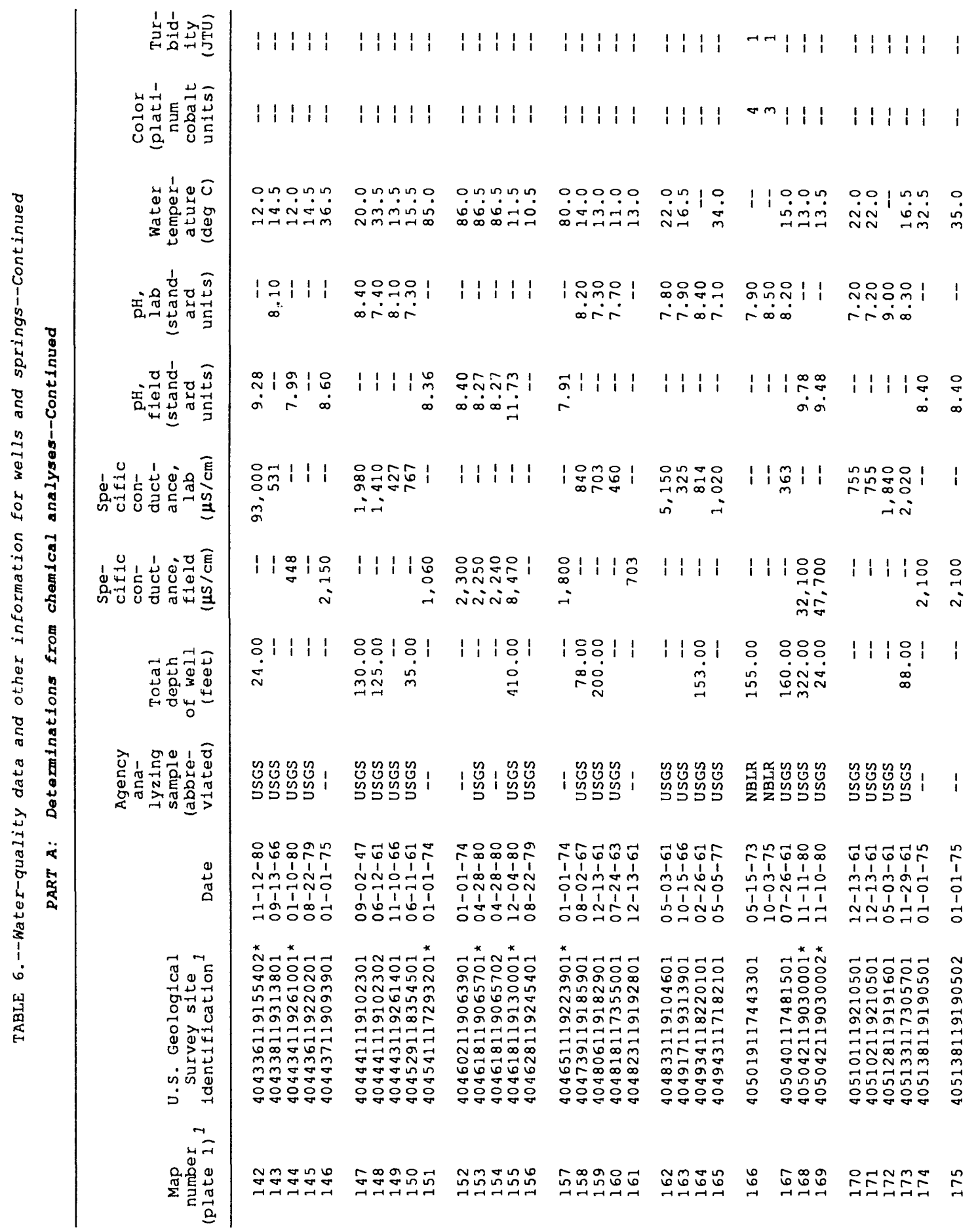




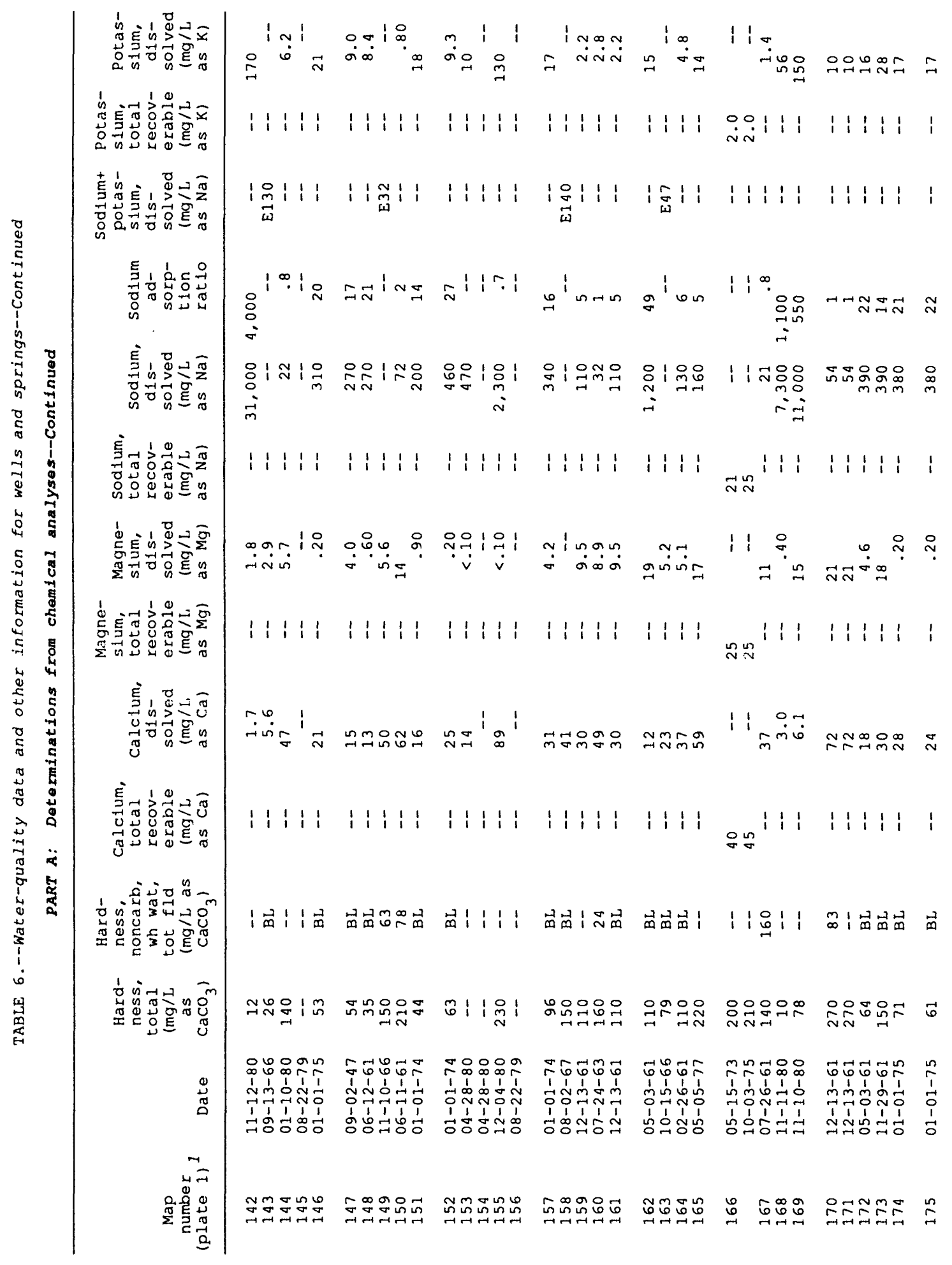




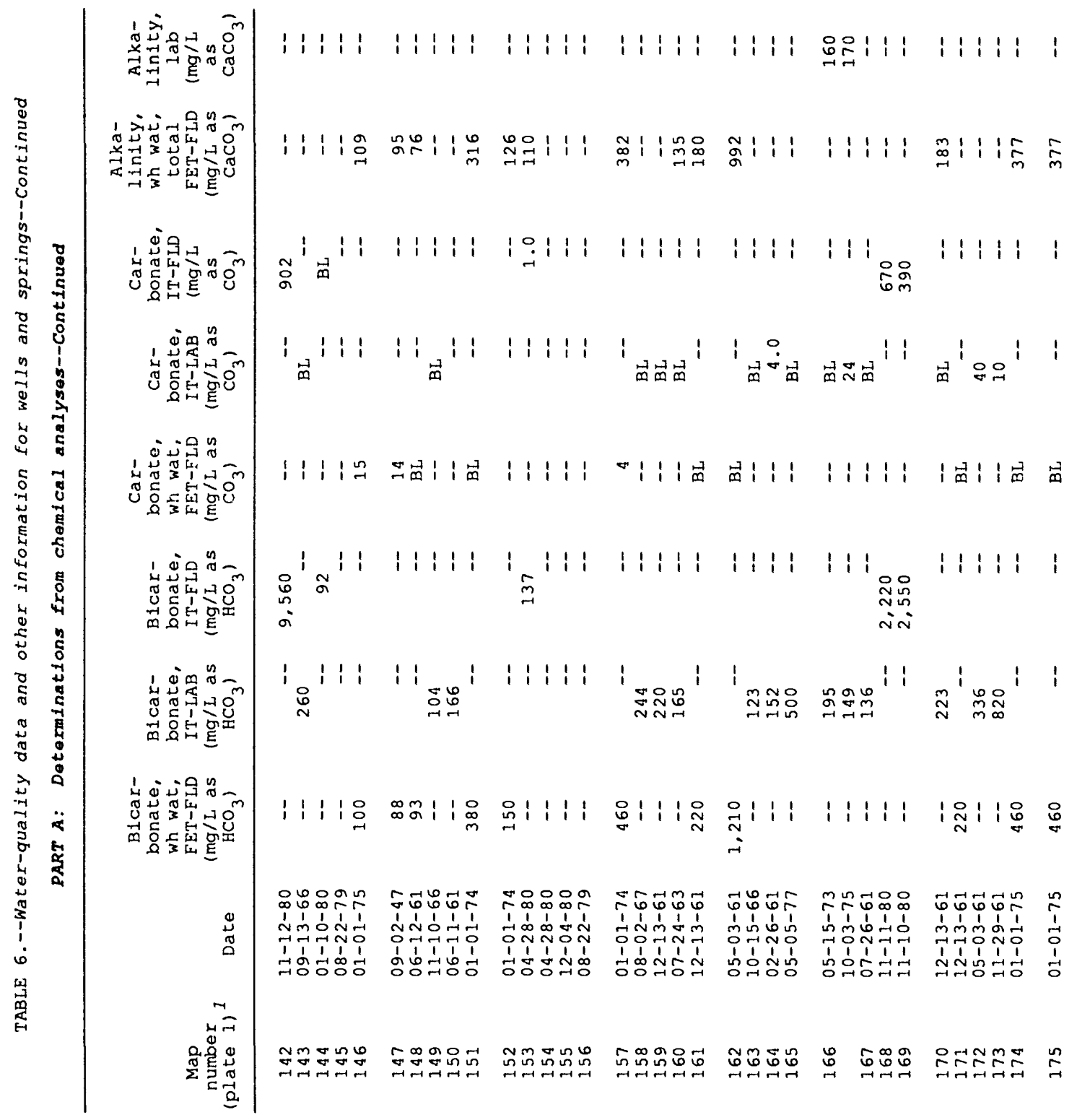




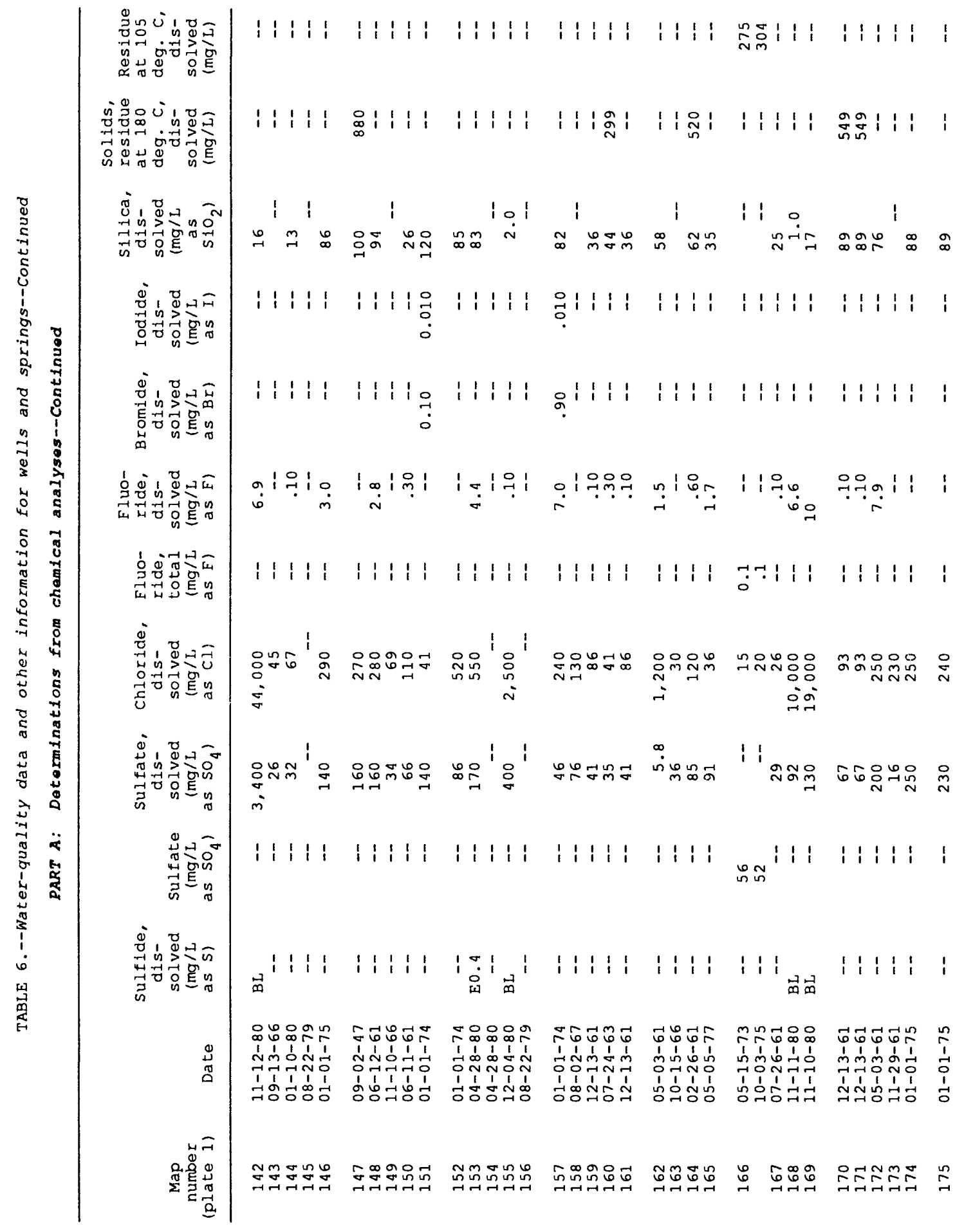




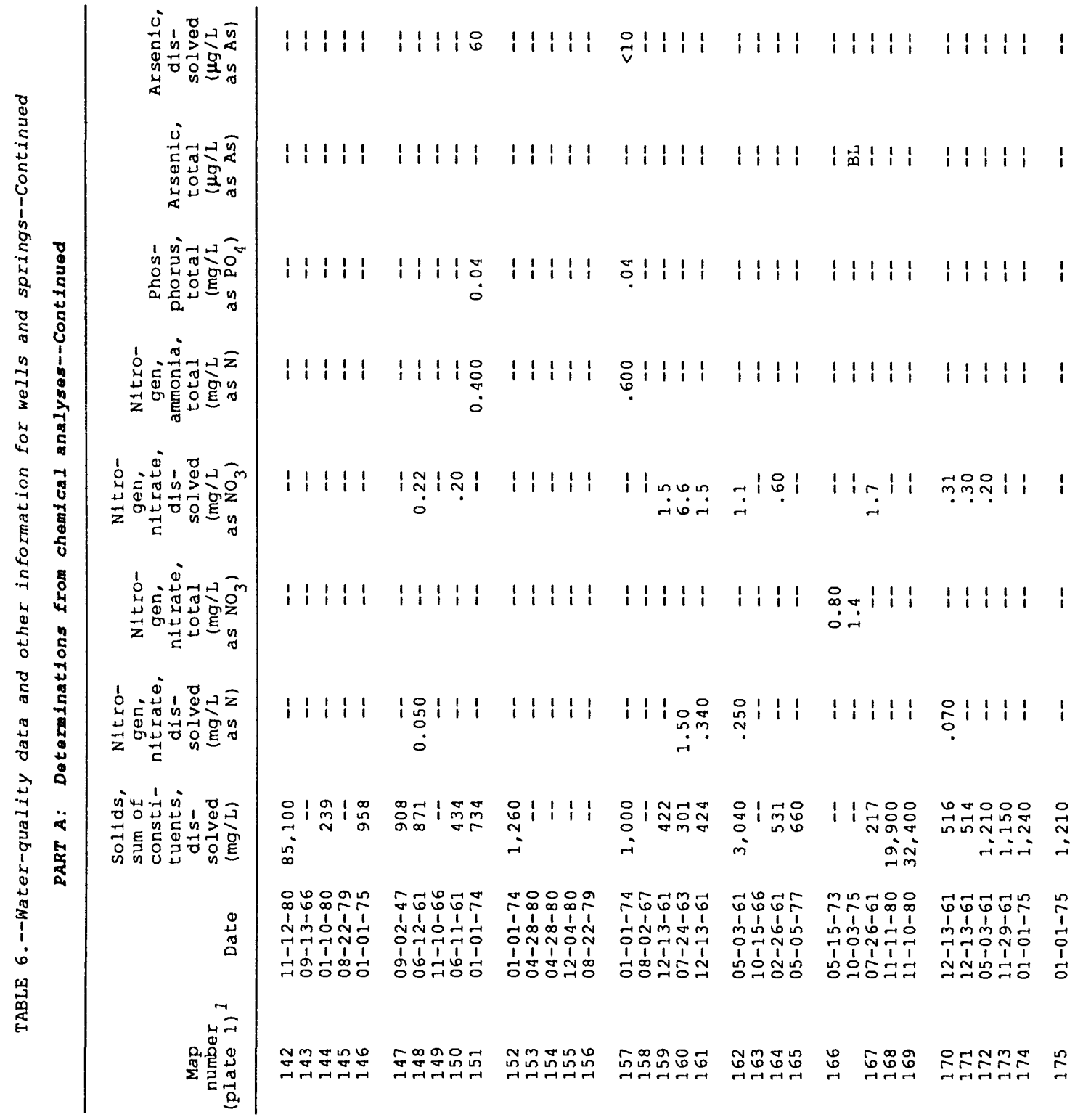




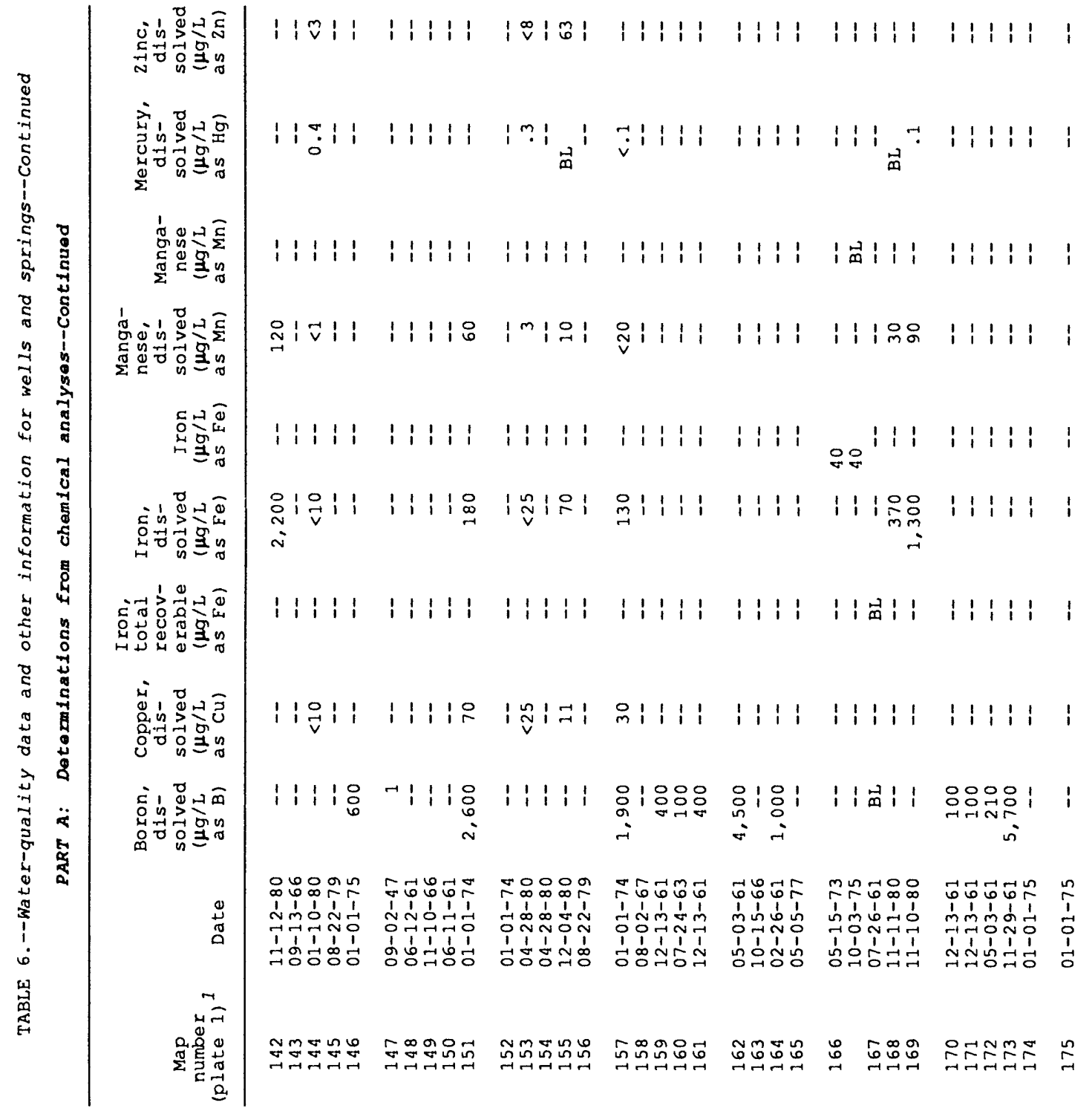




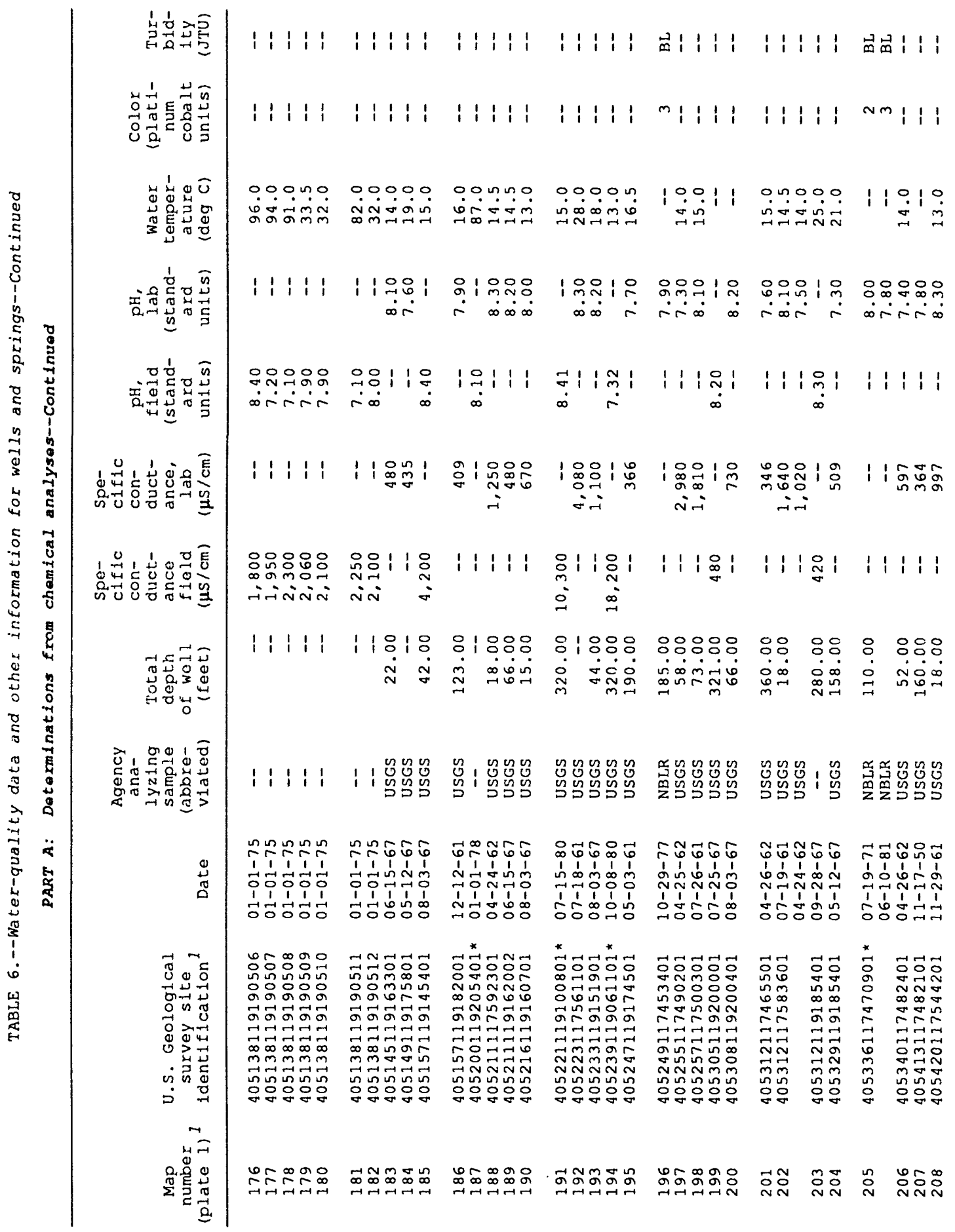




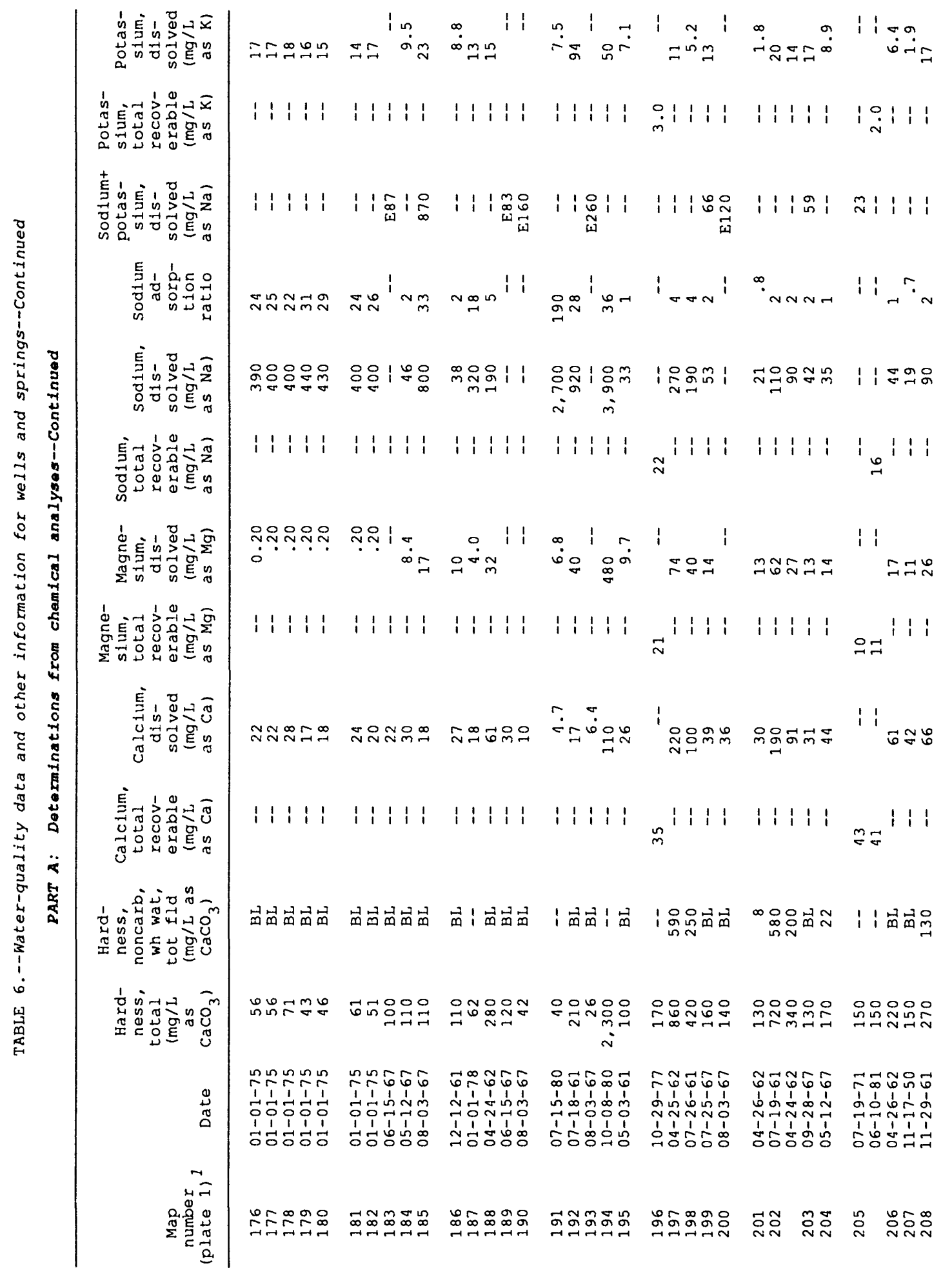




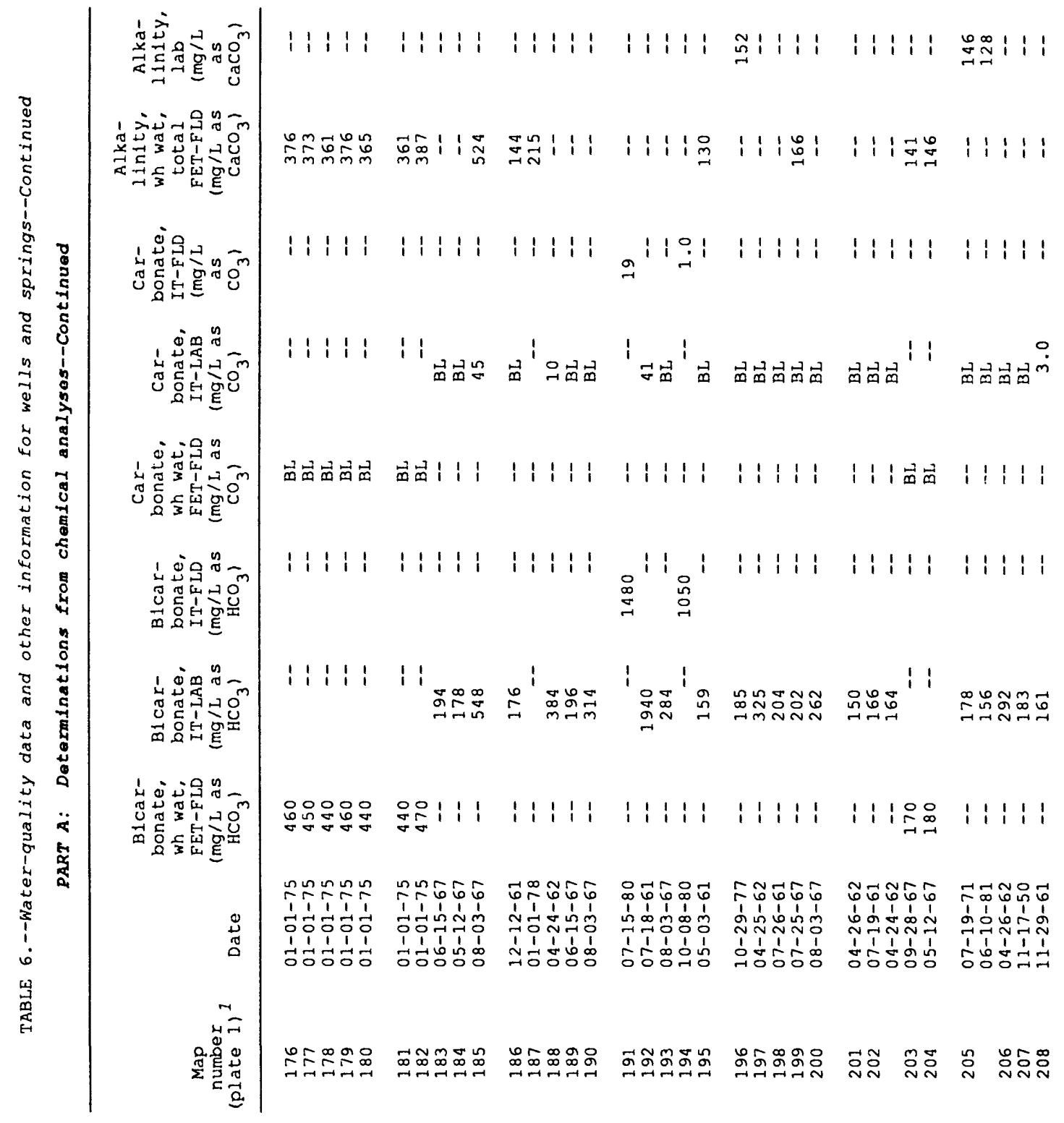




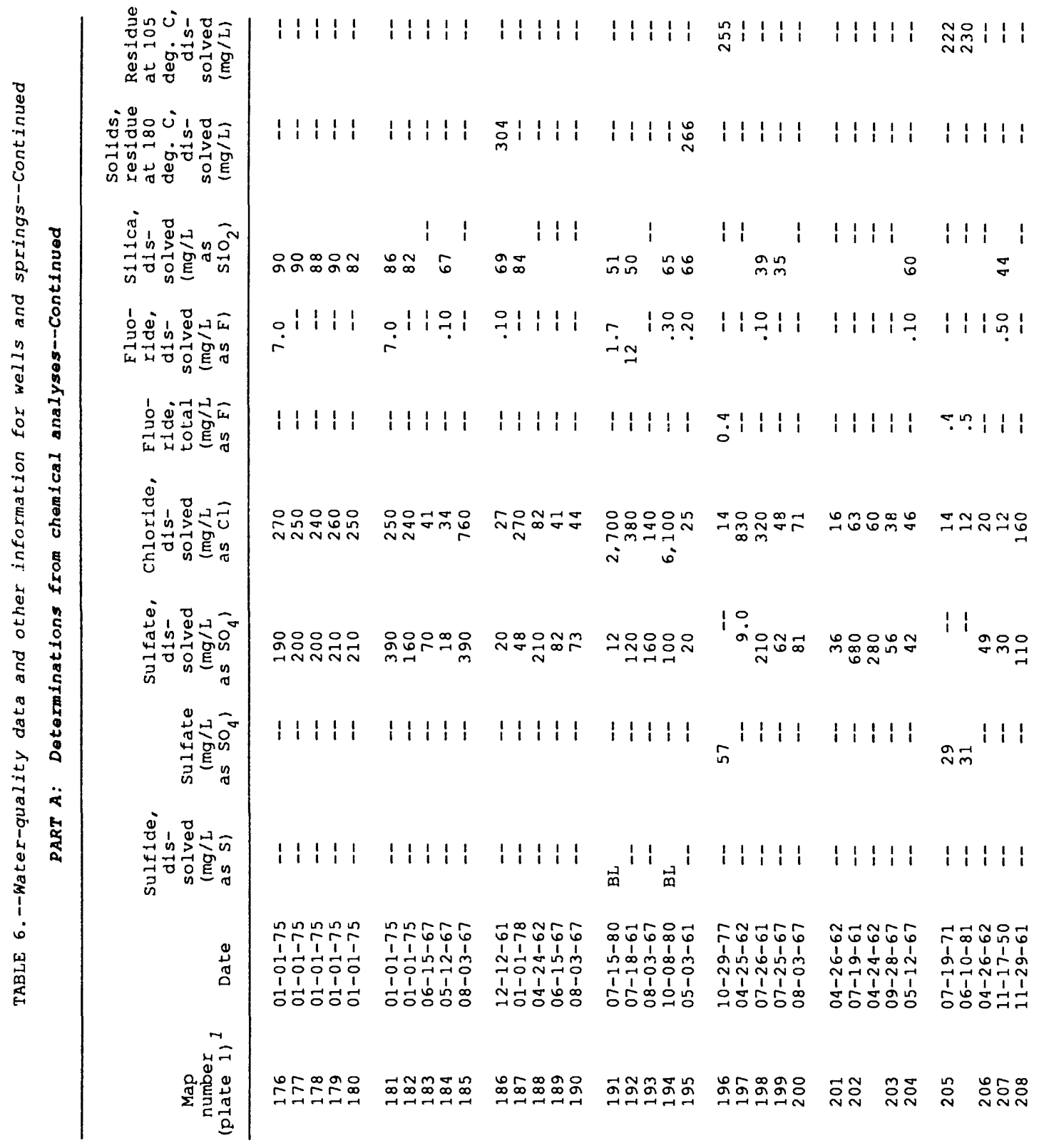




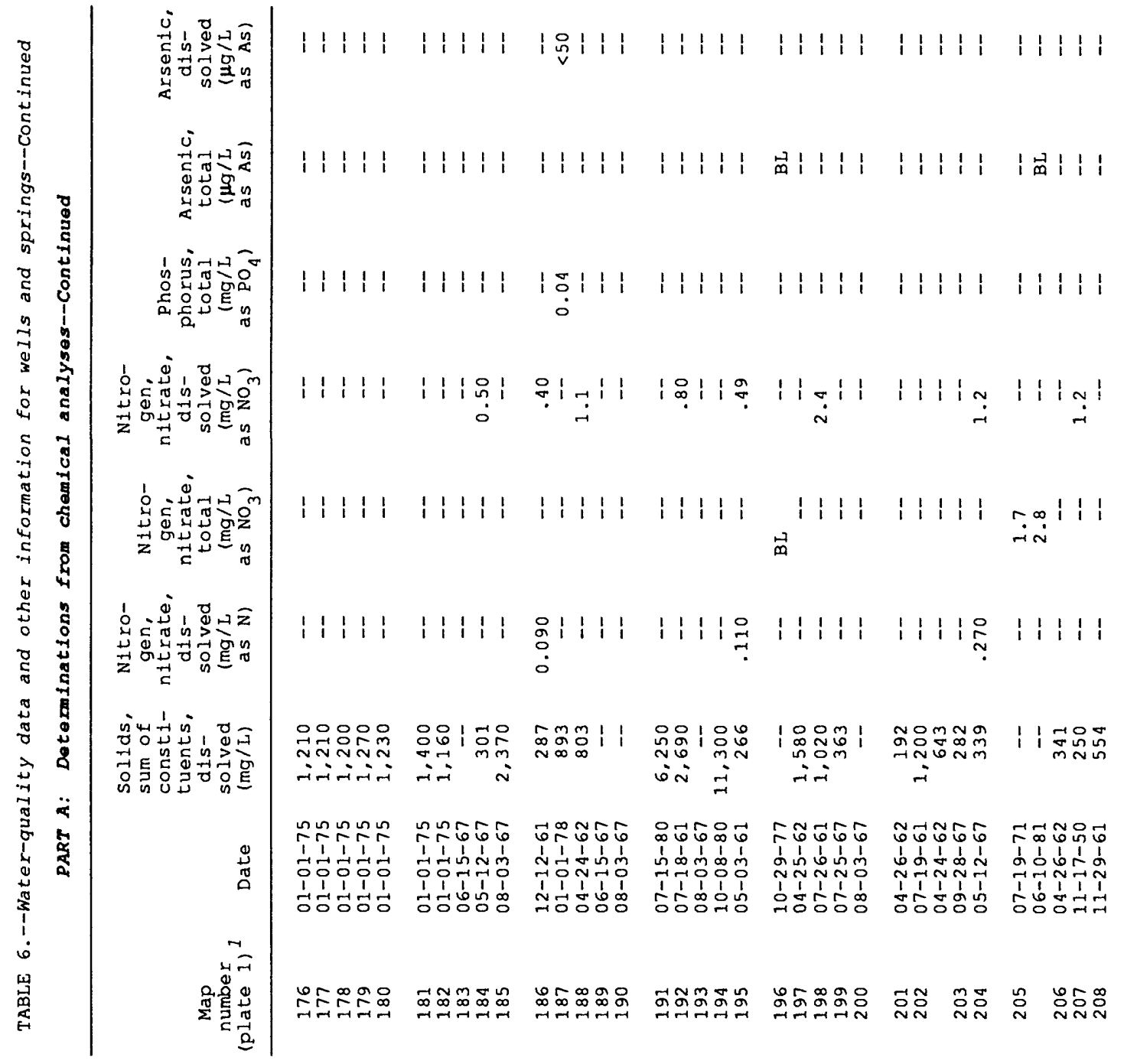




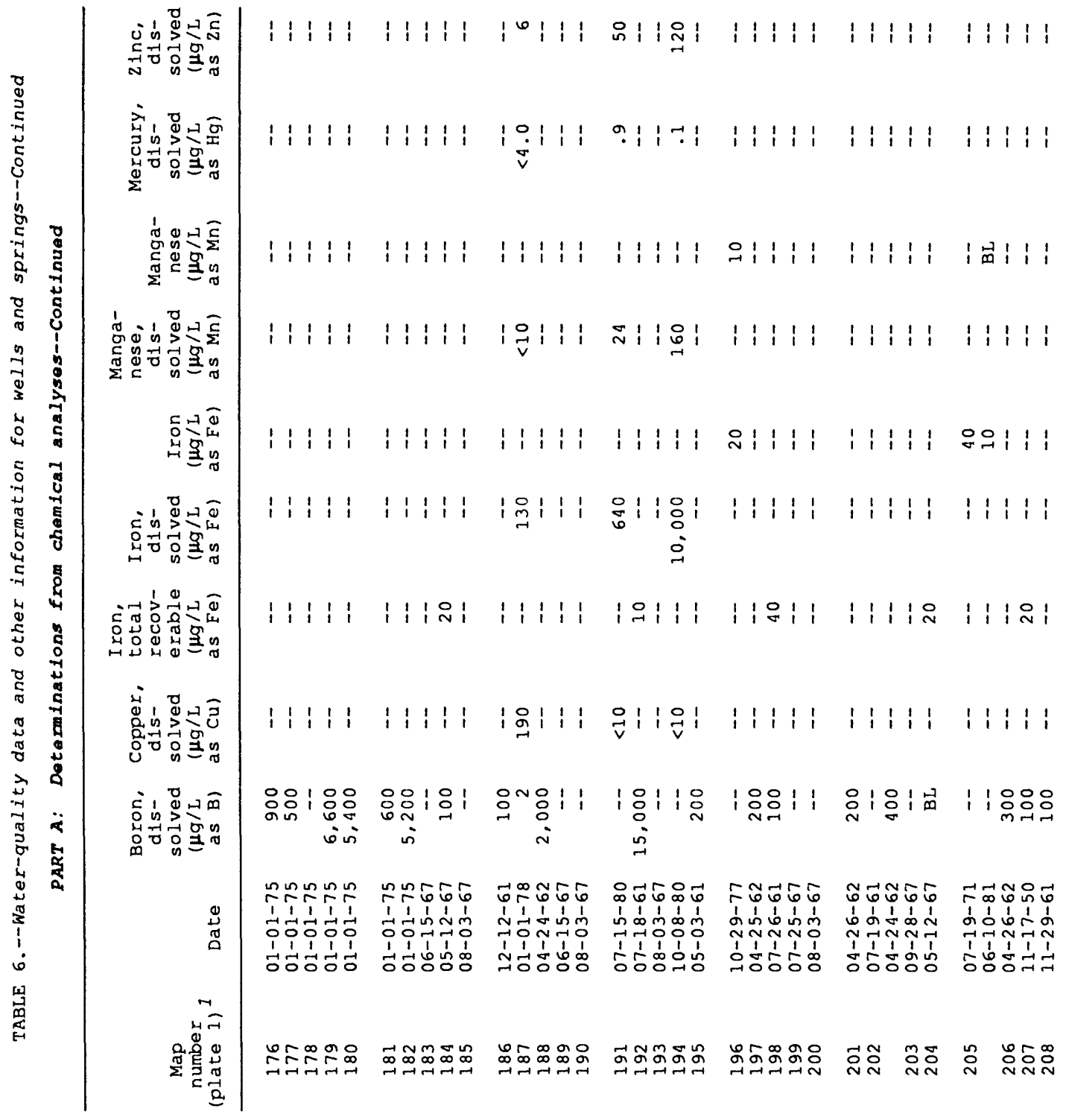




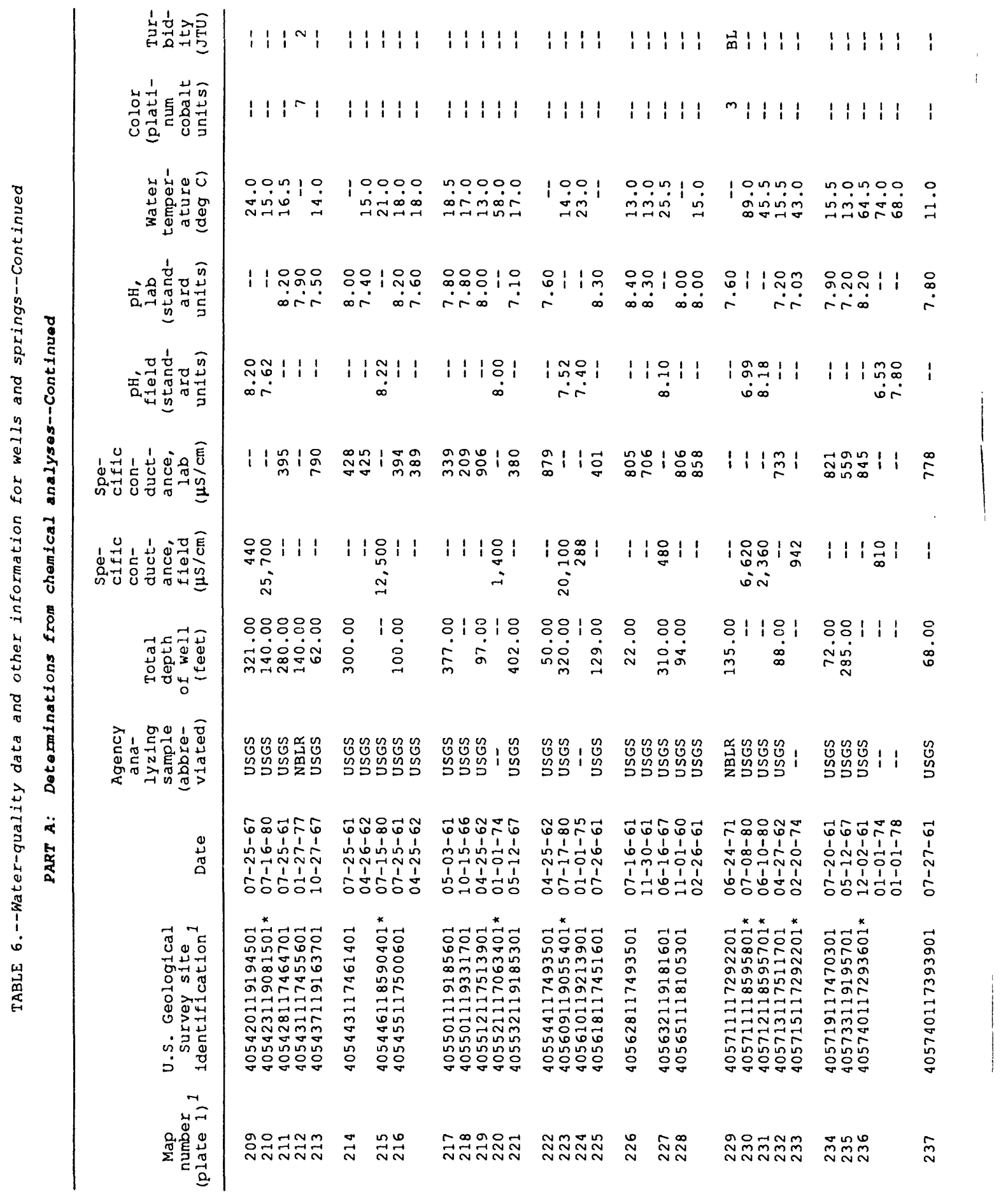




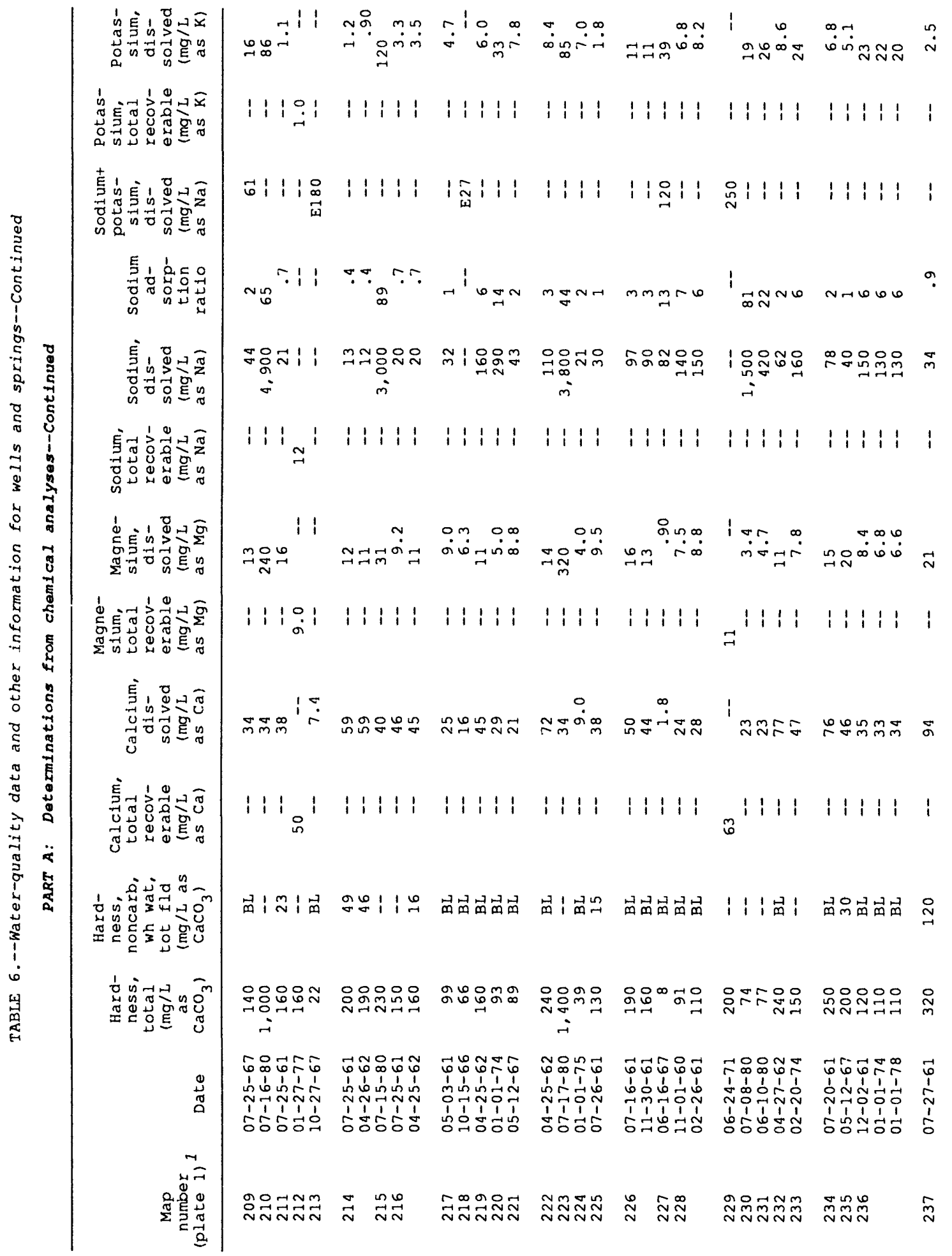




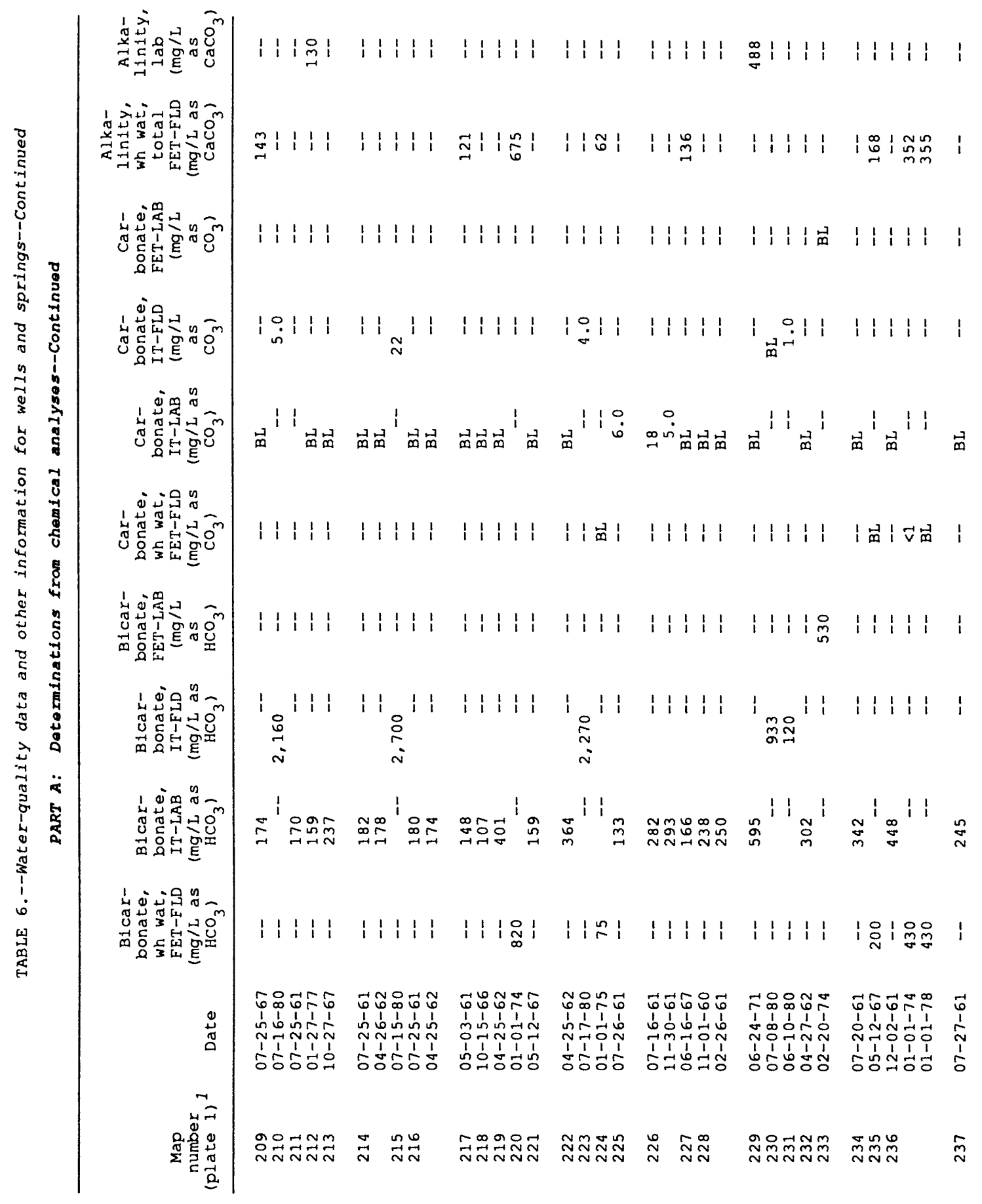




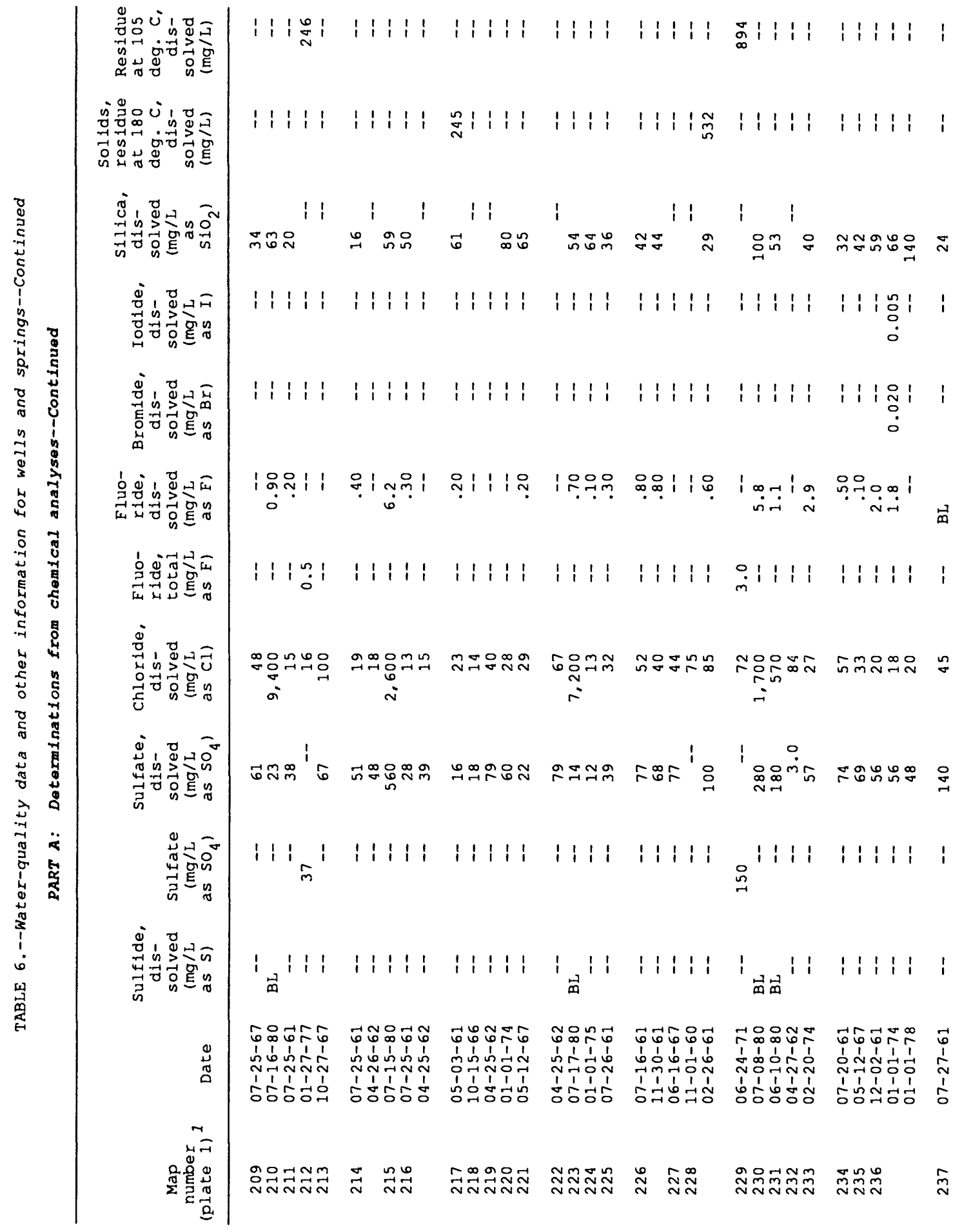




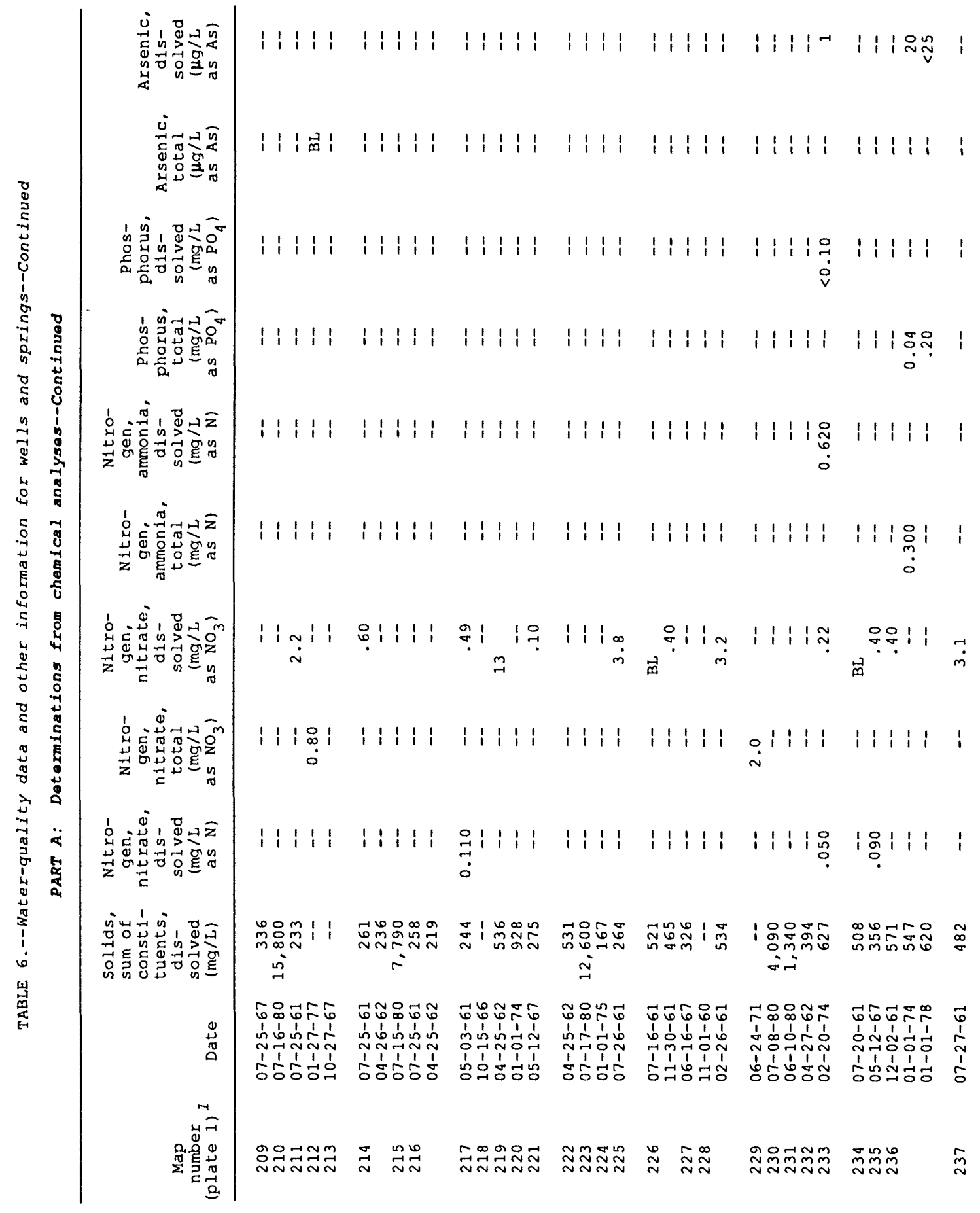




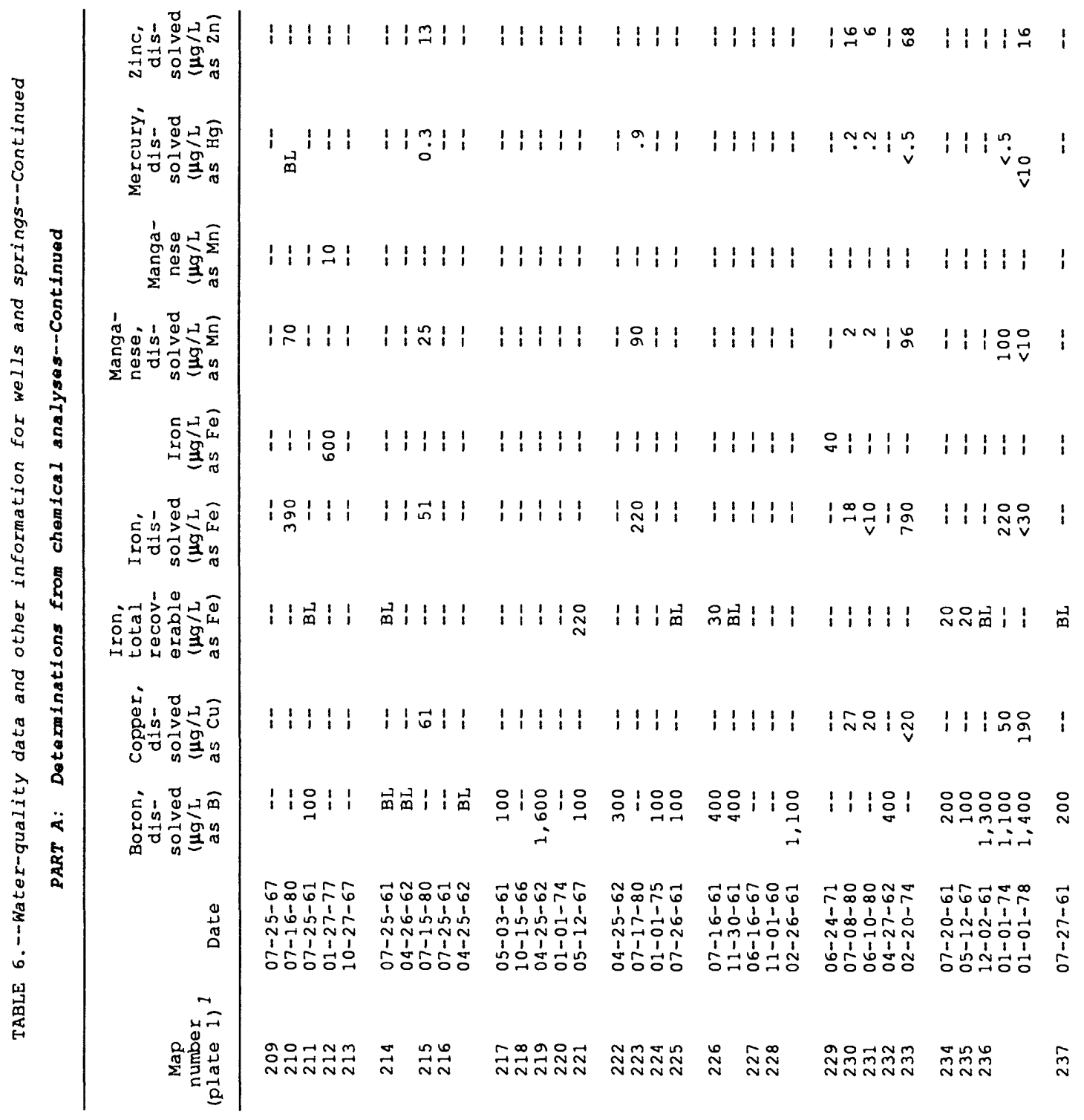




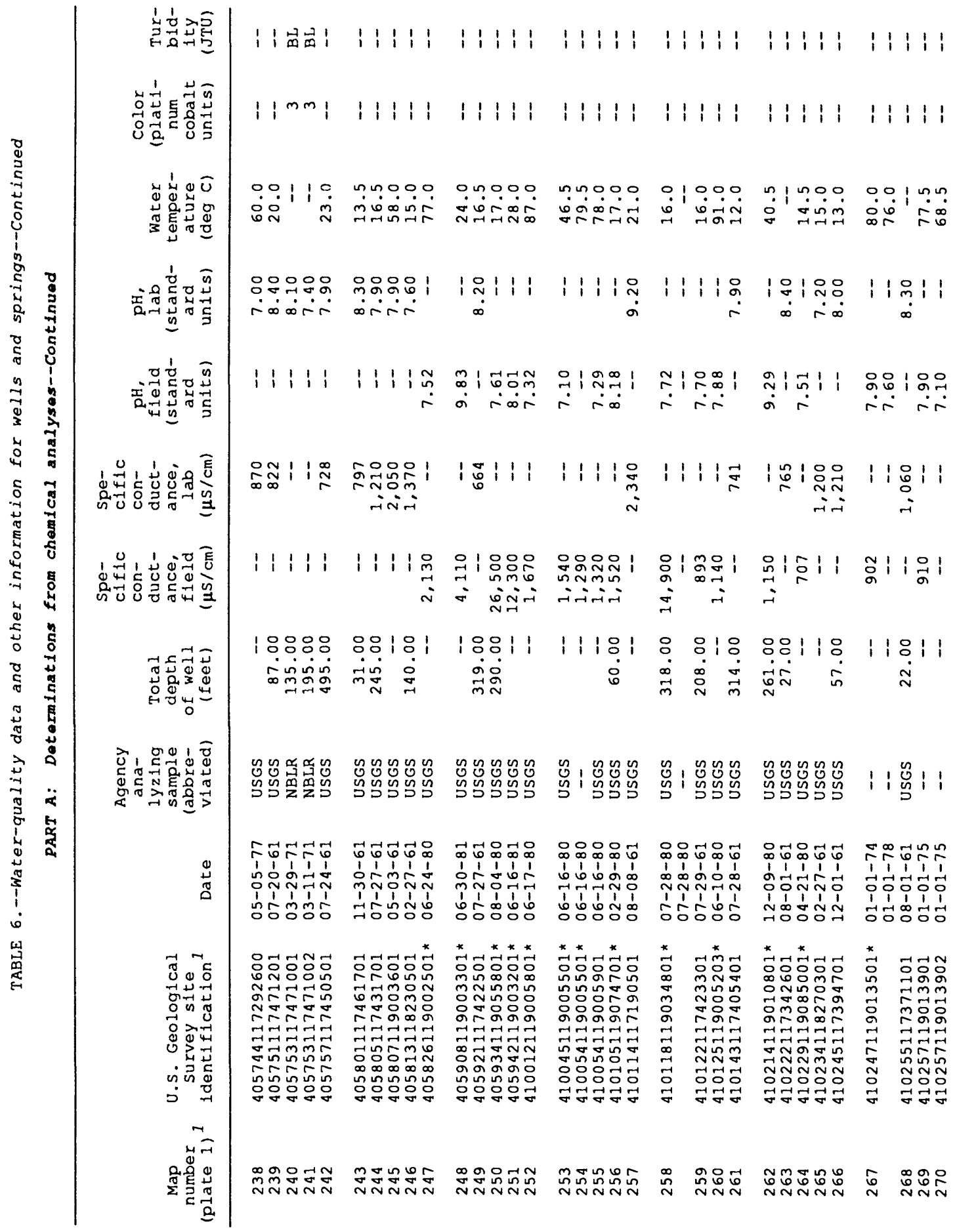




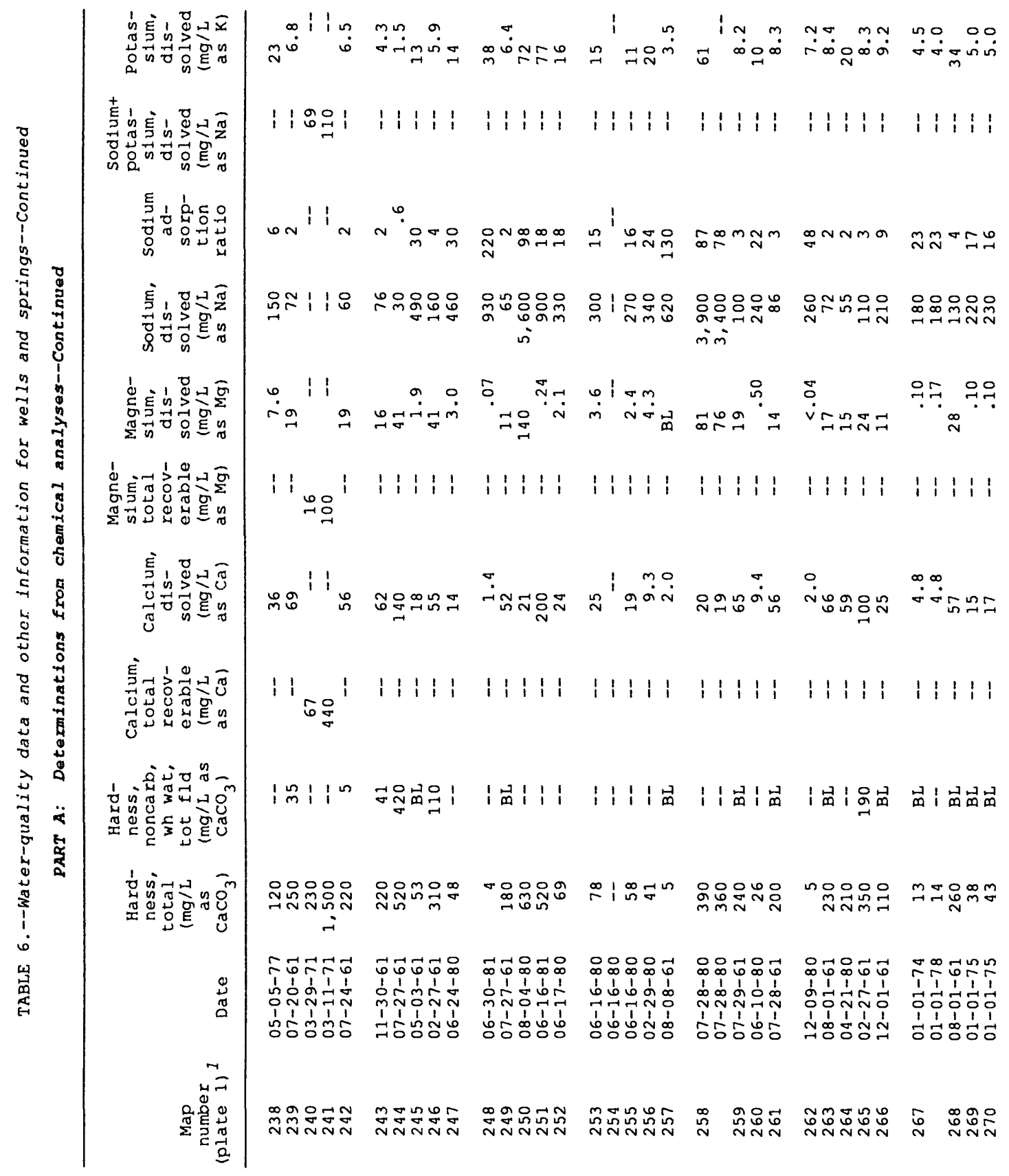




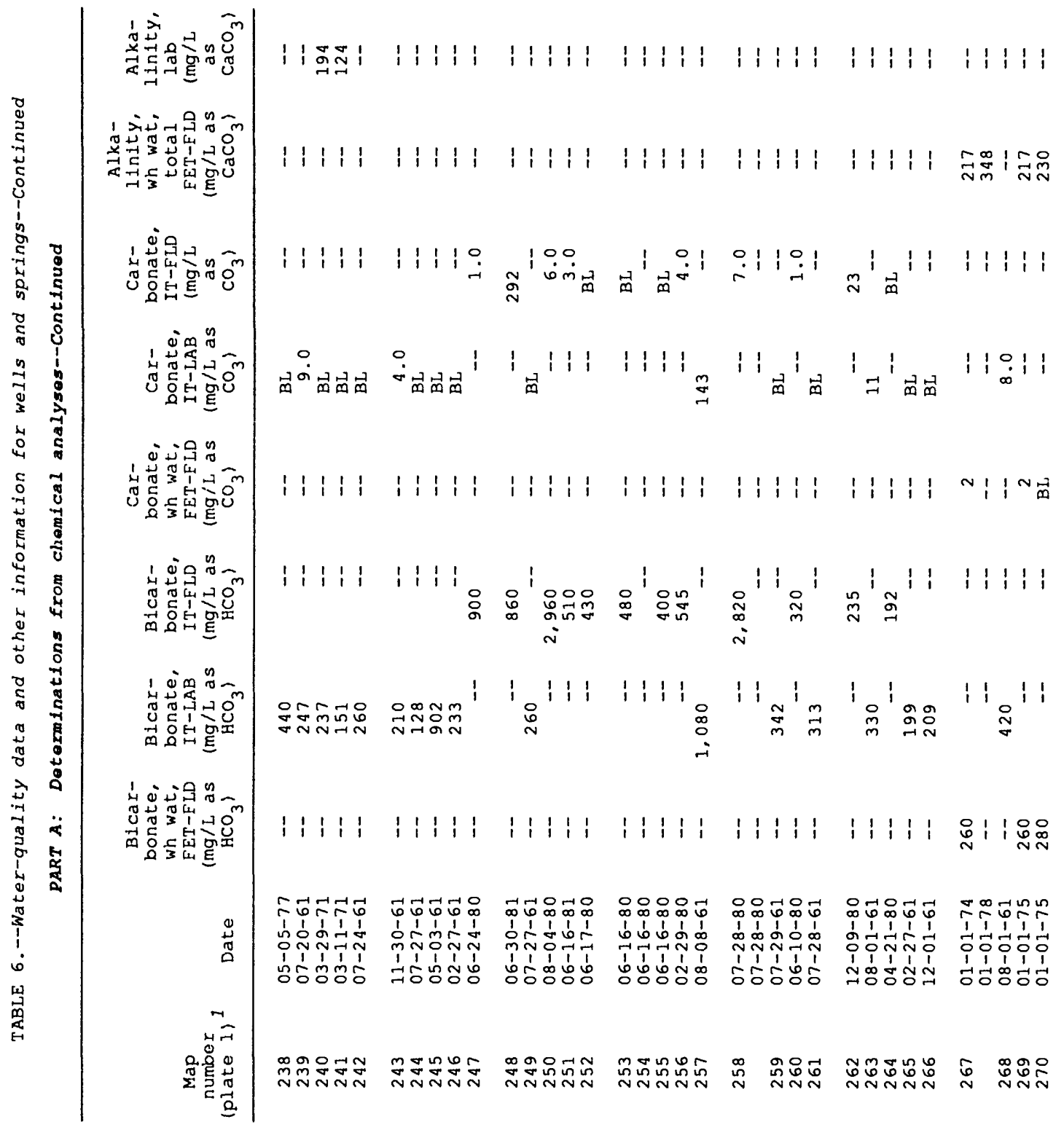




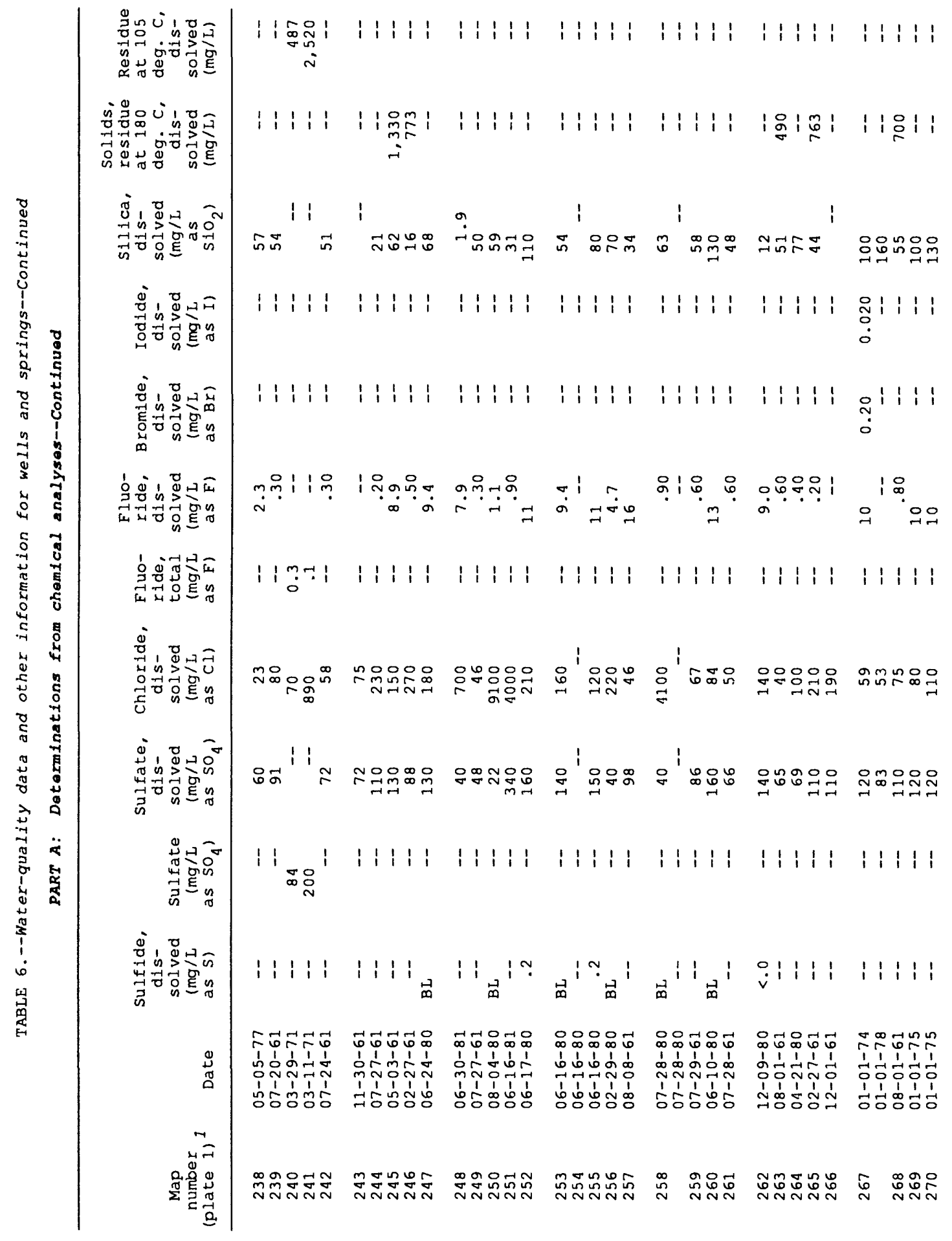




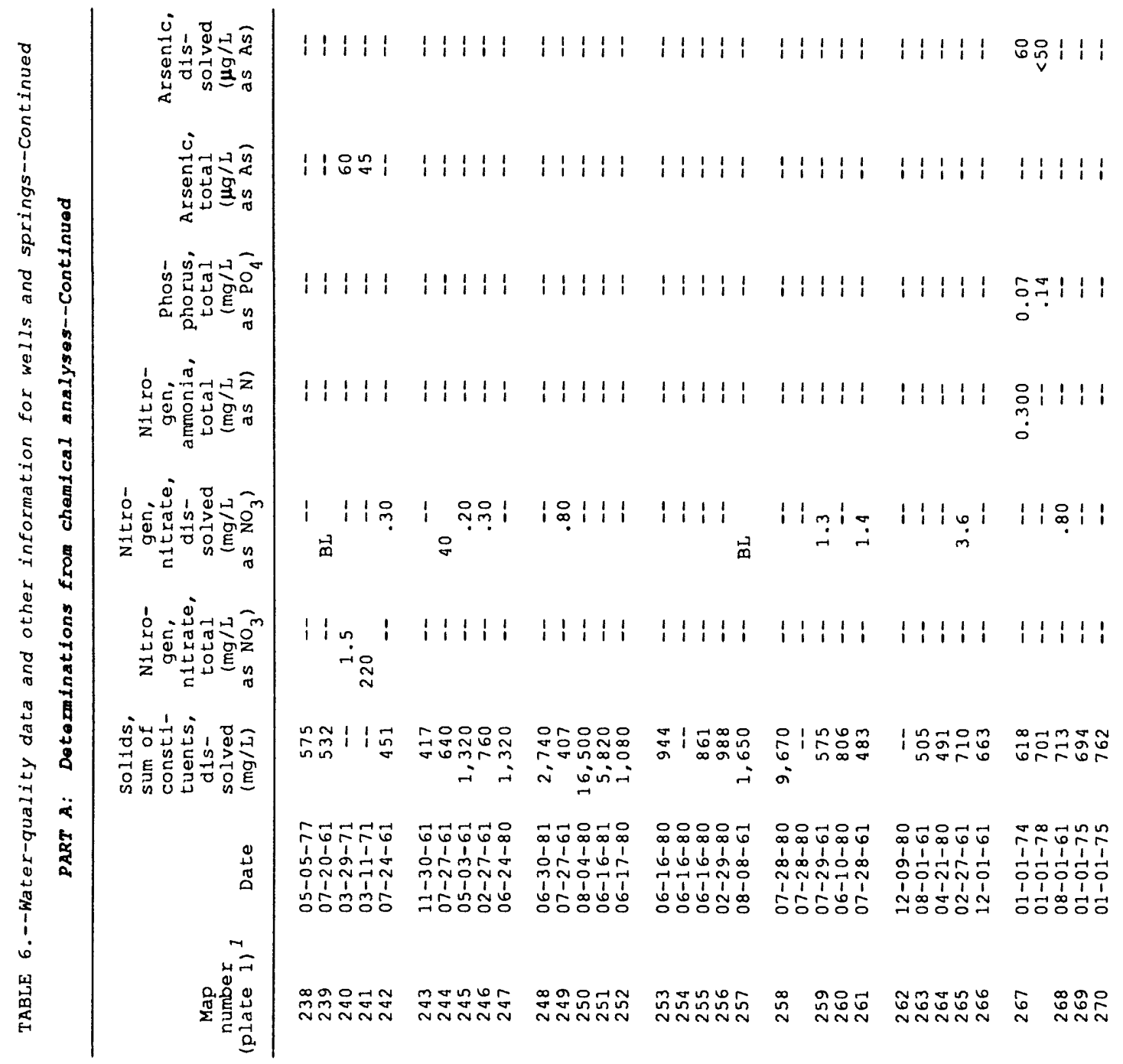




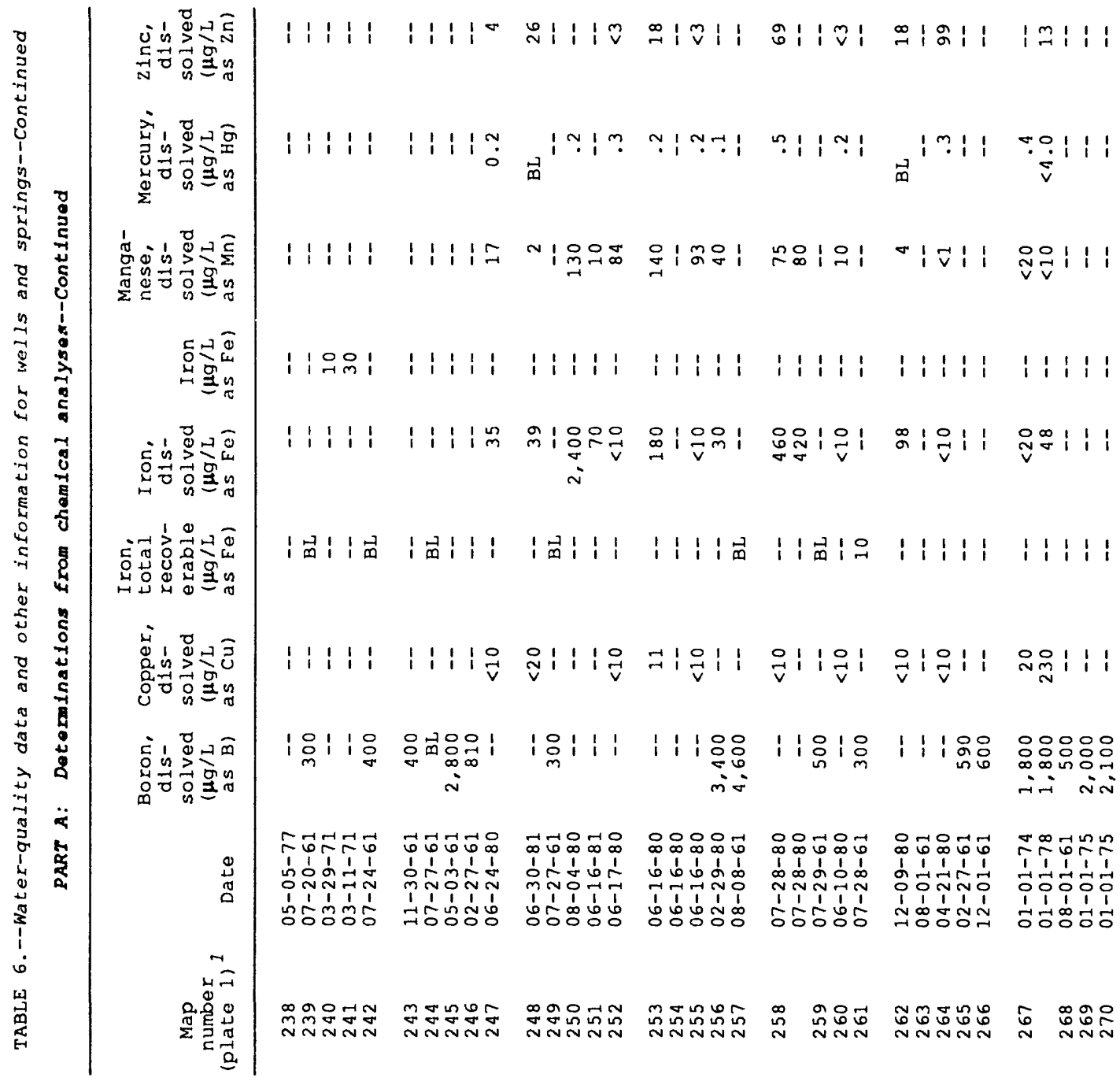




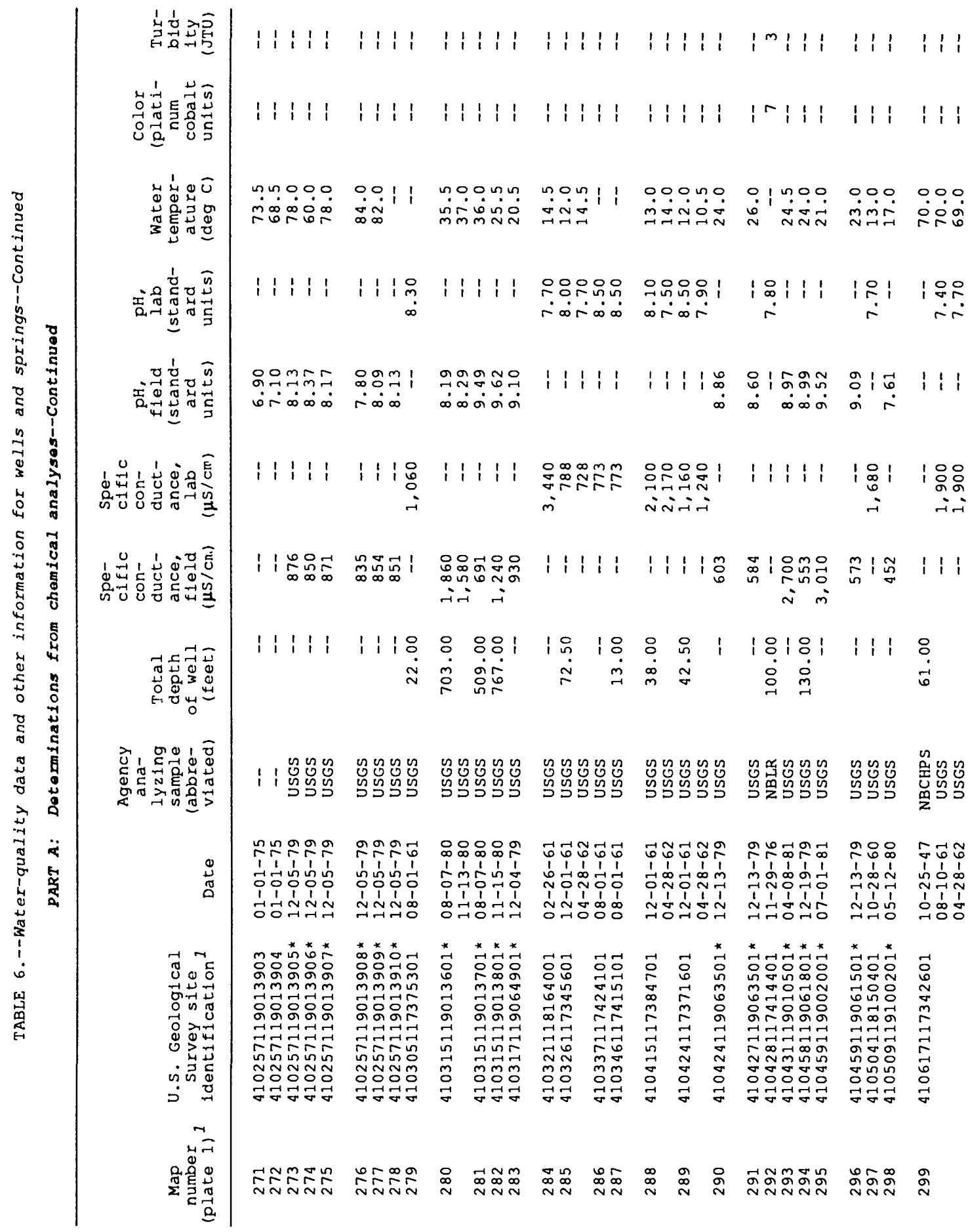




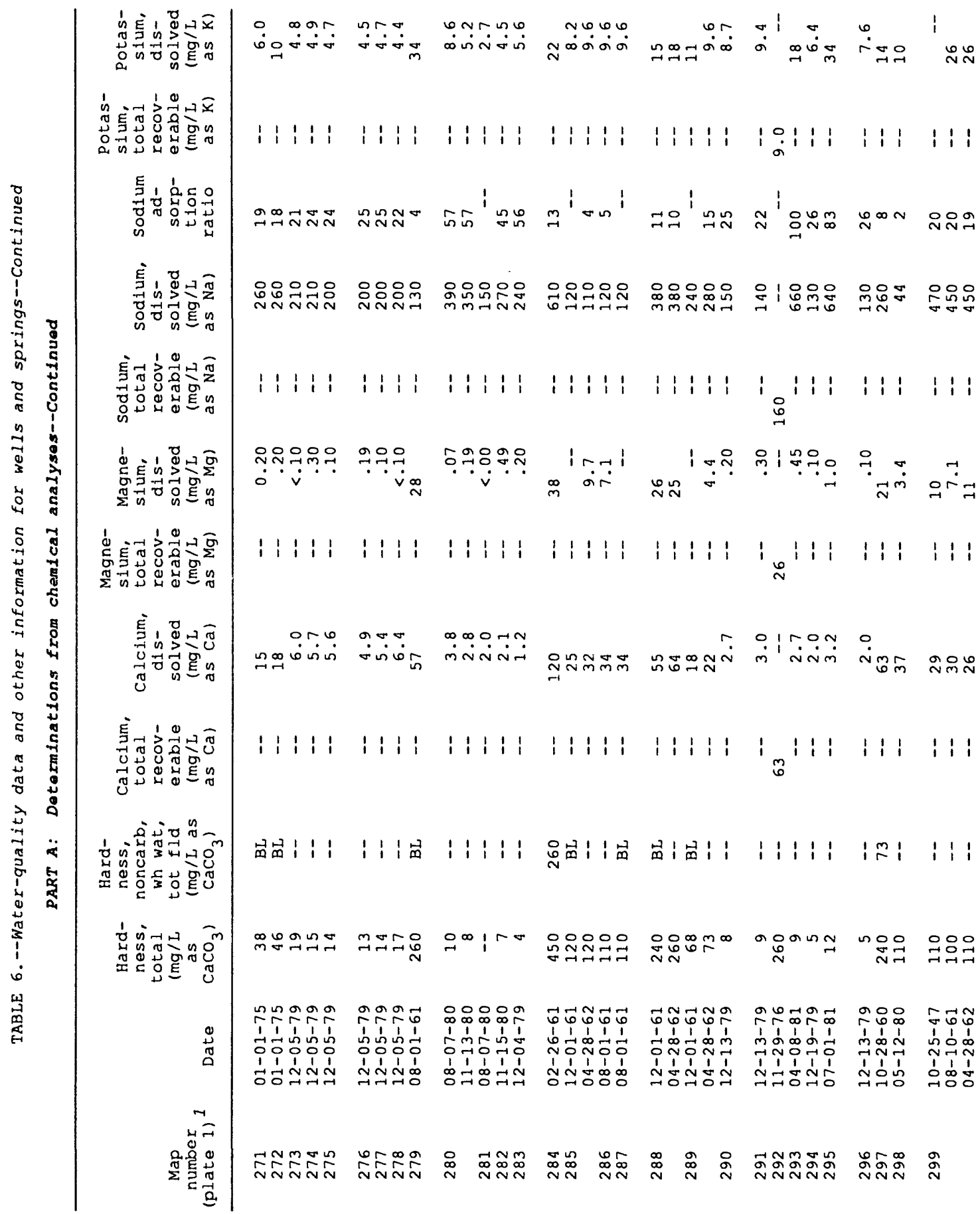




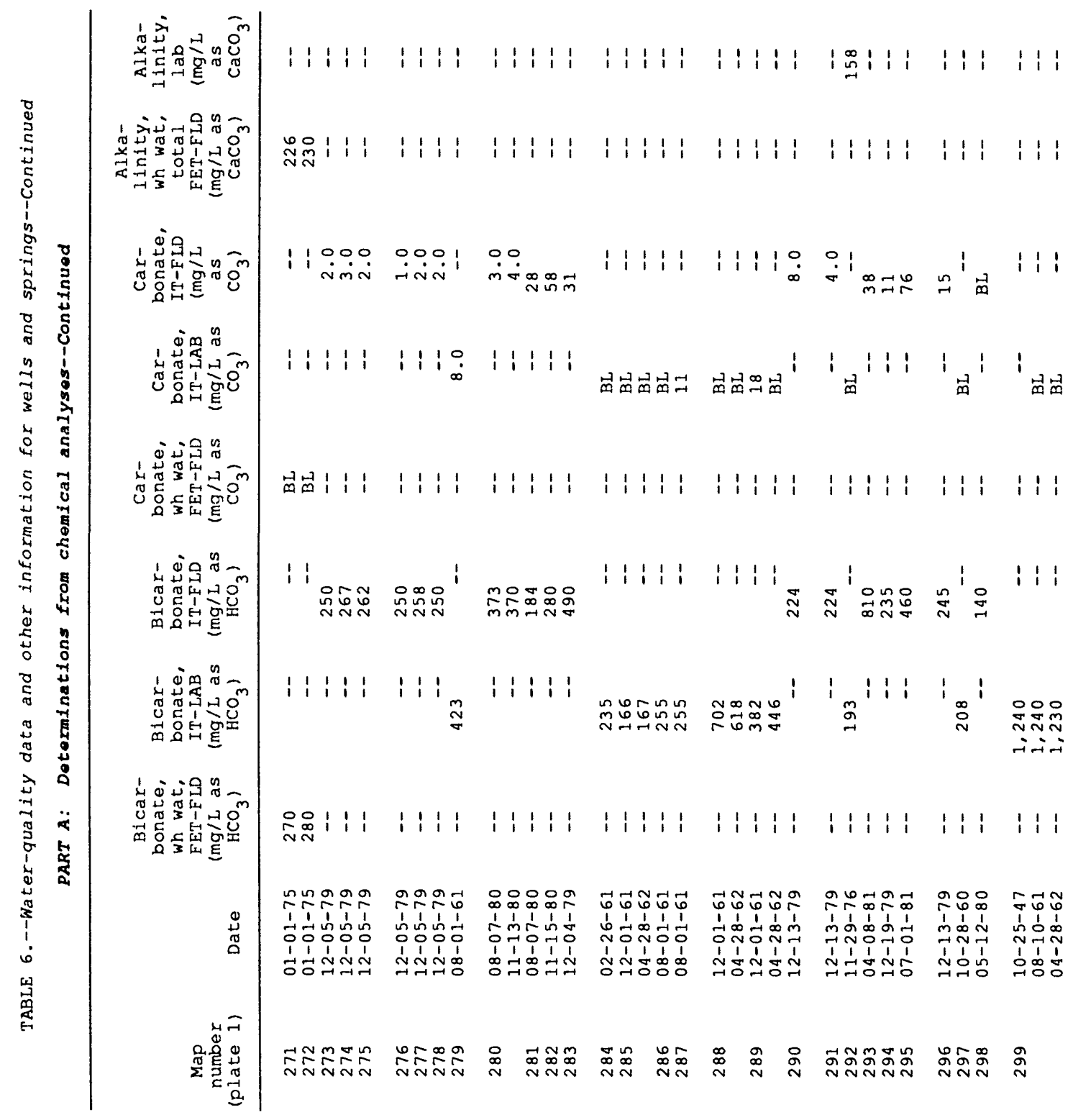




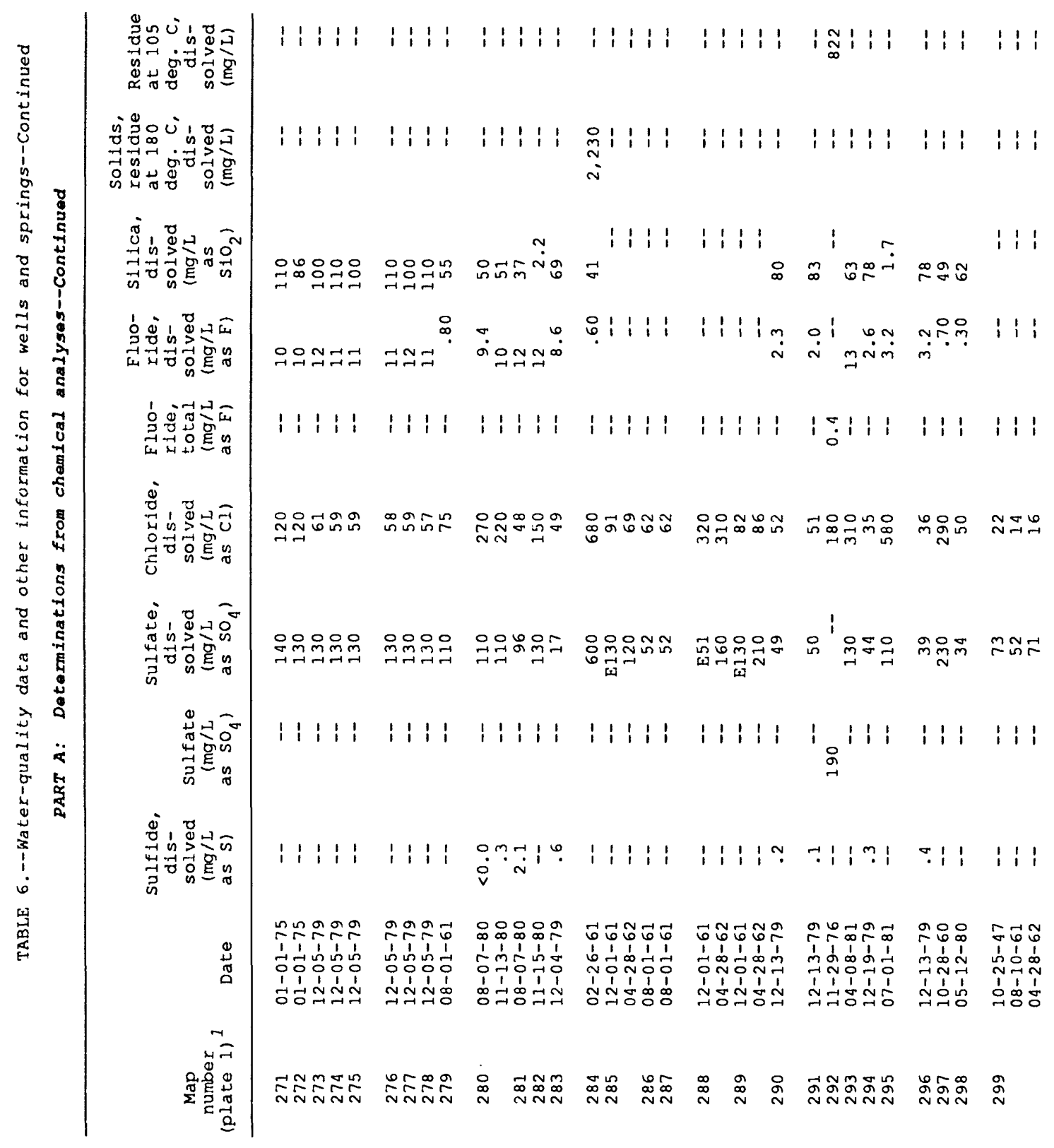




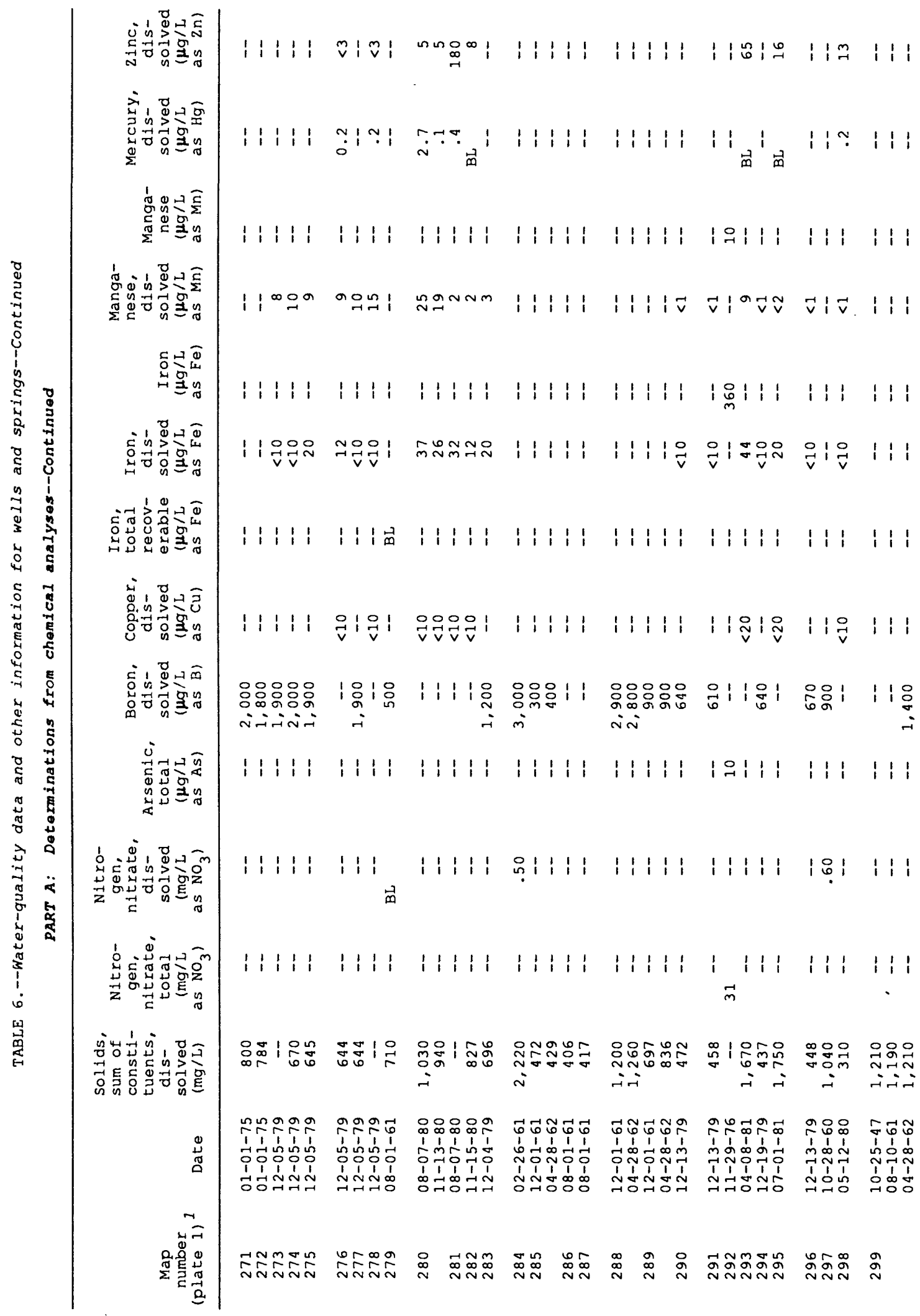




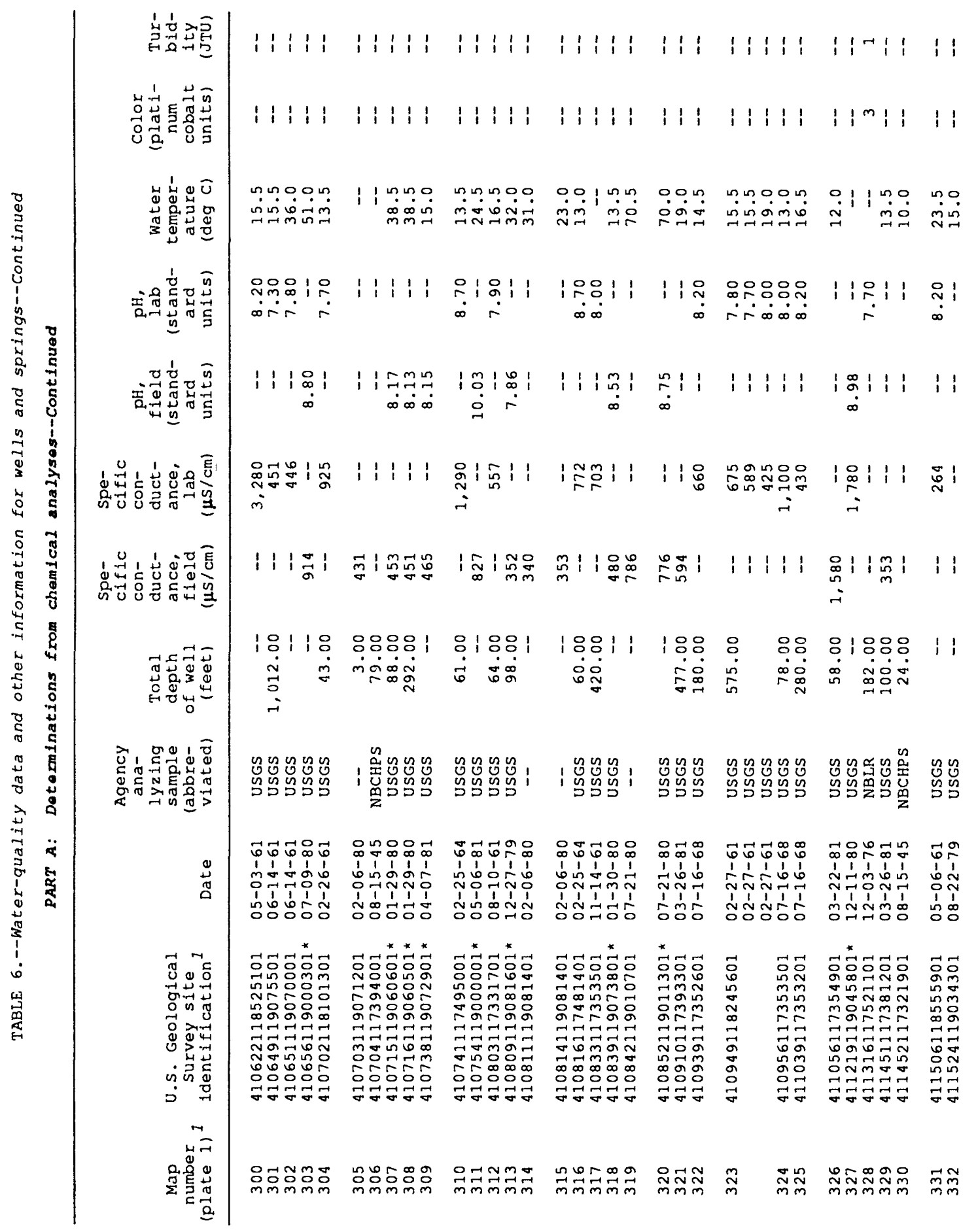




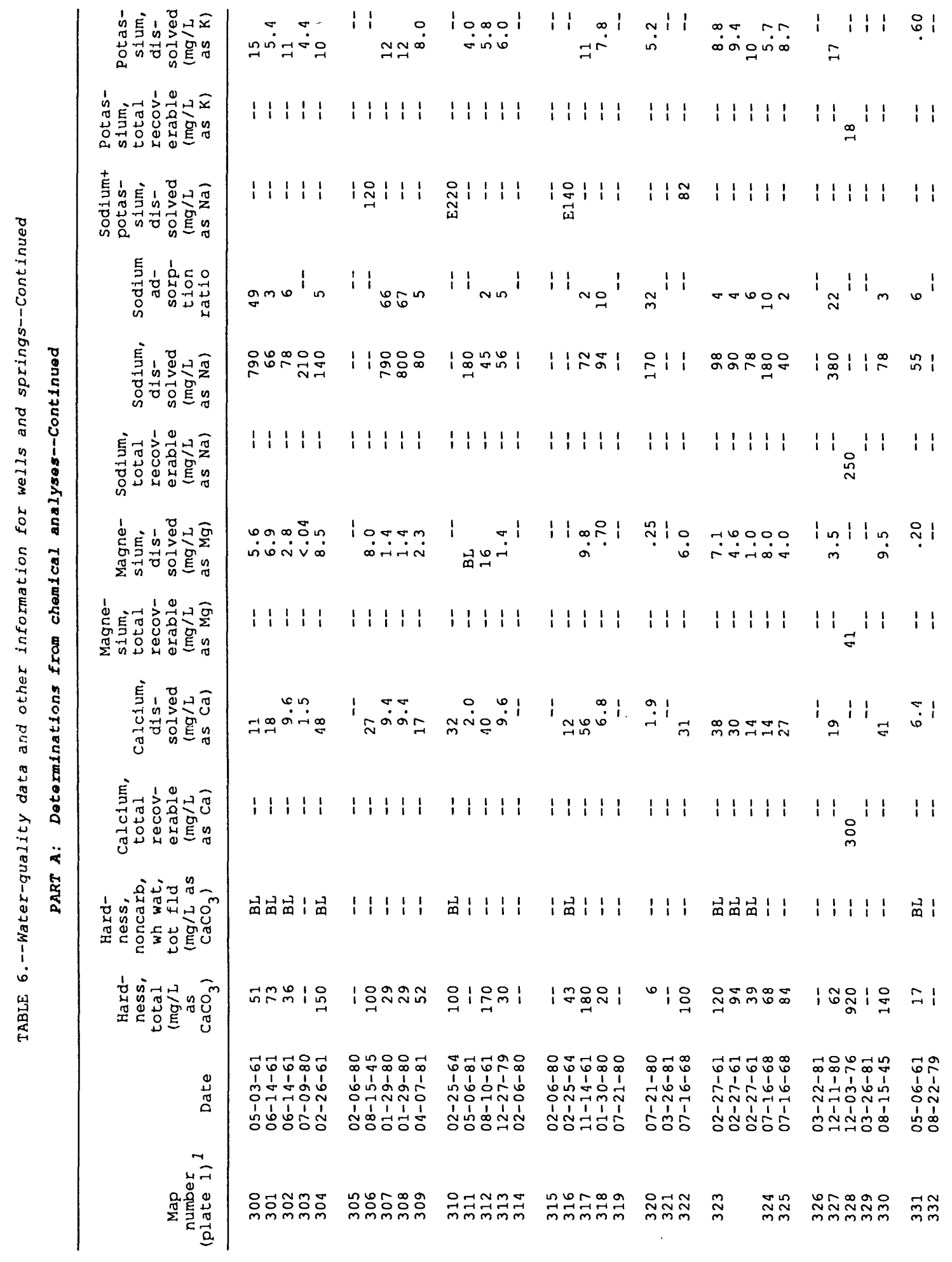




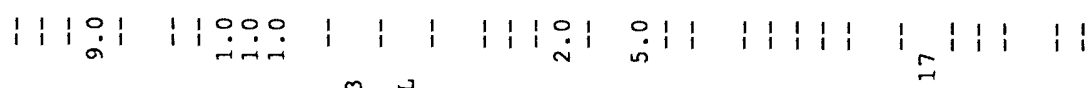
임

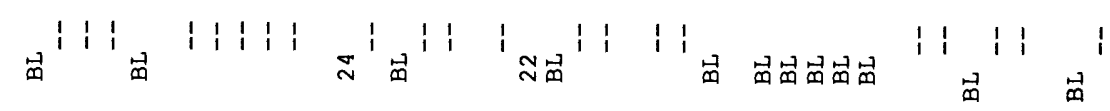

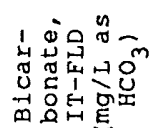

H1

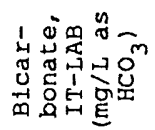

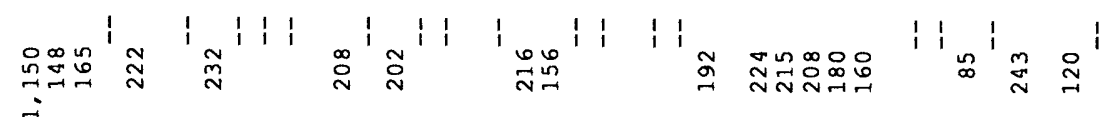

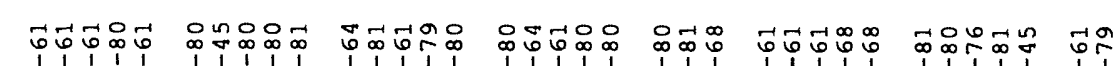

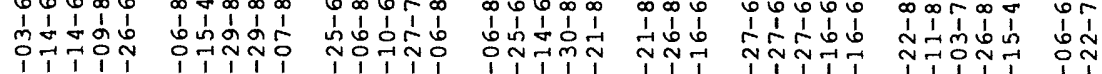

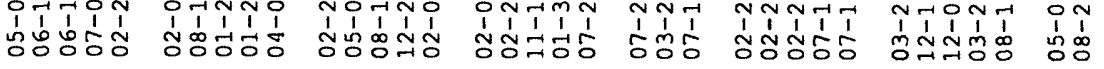

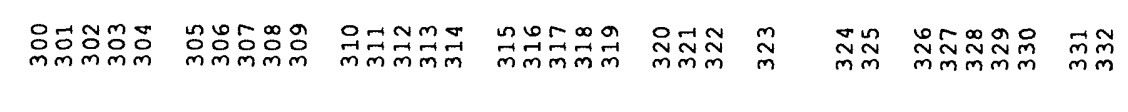




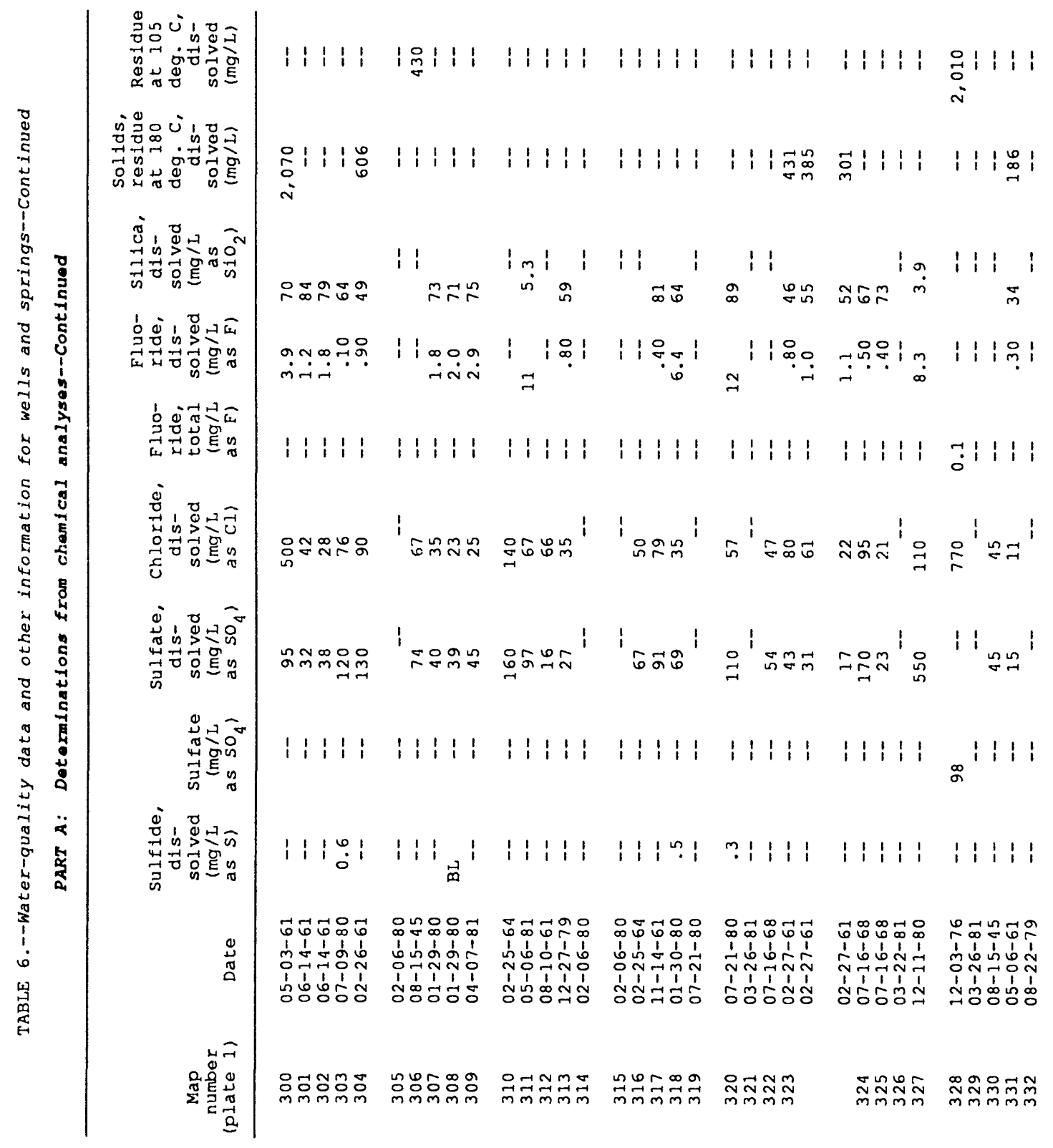




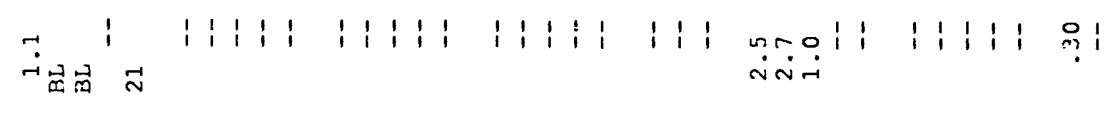

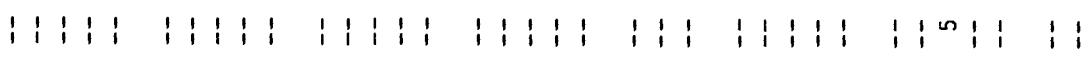

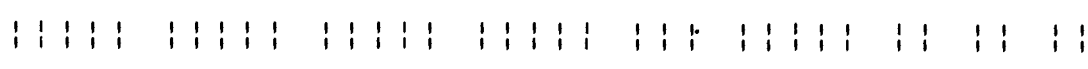

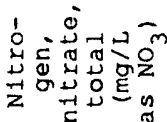

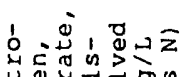

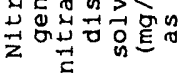

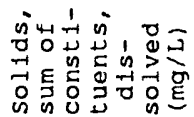

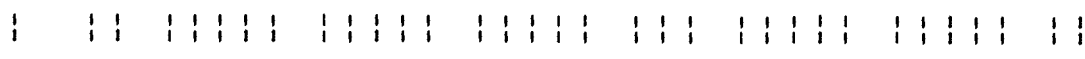
岗藏

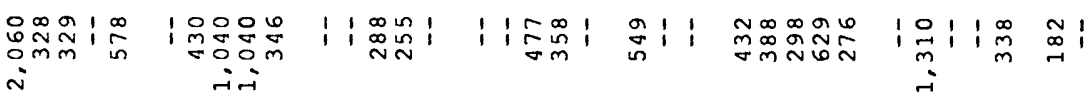

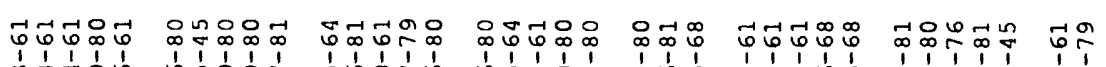

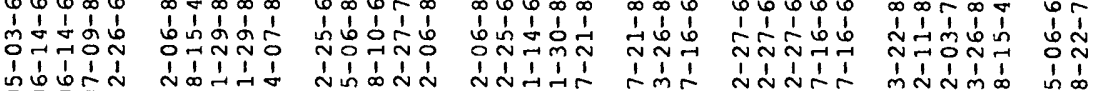

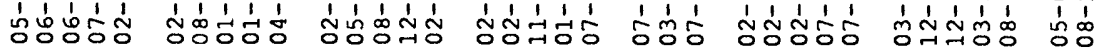

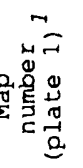

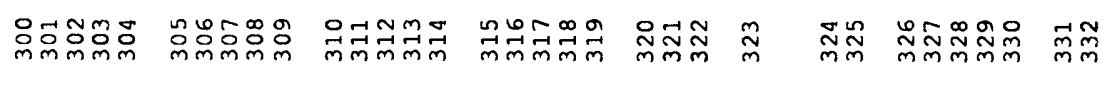




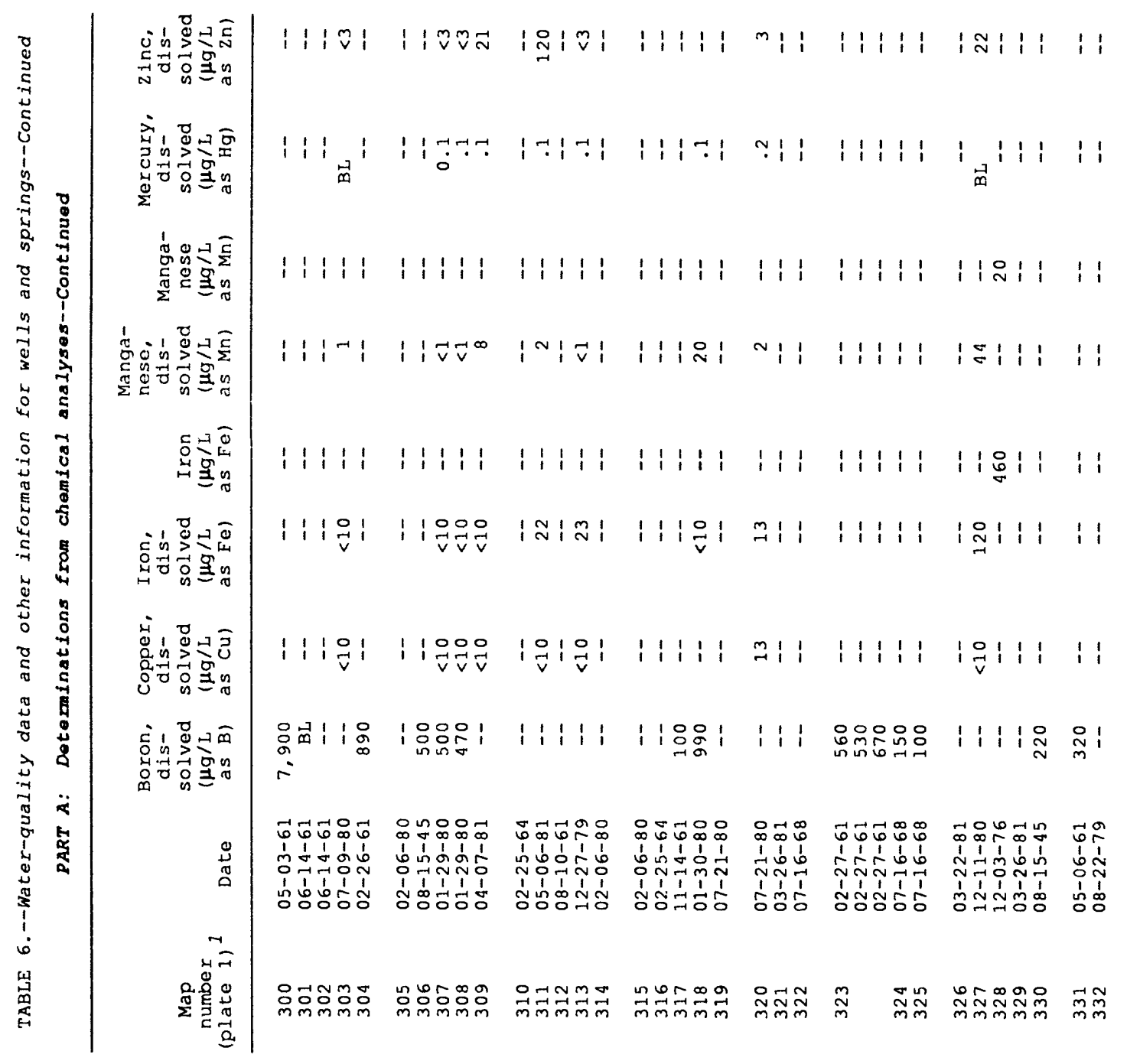




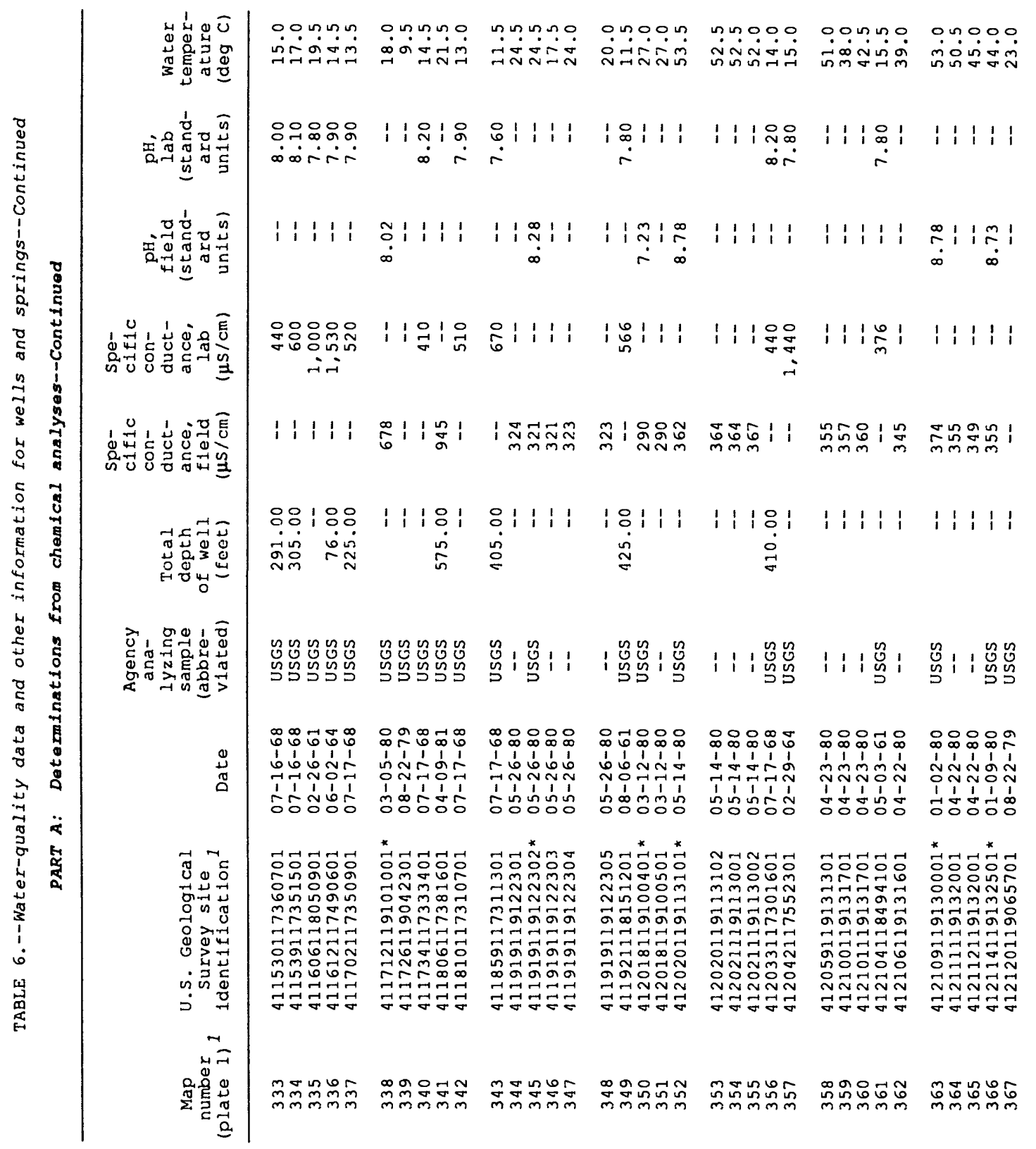




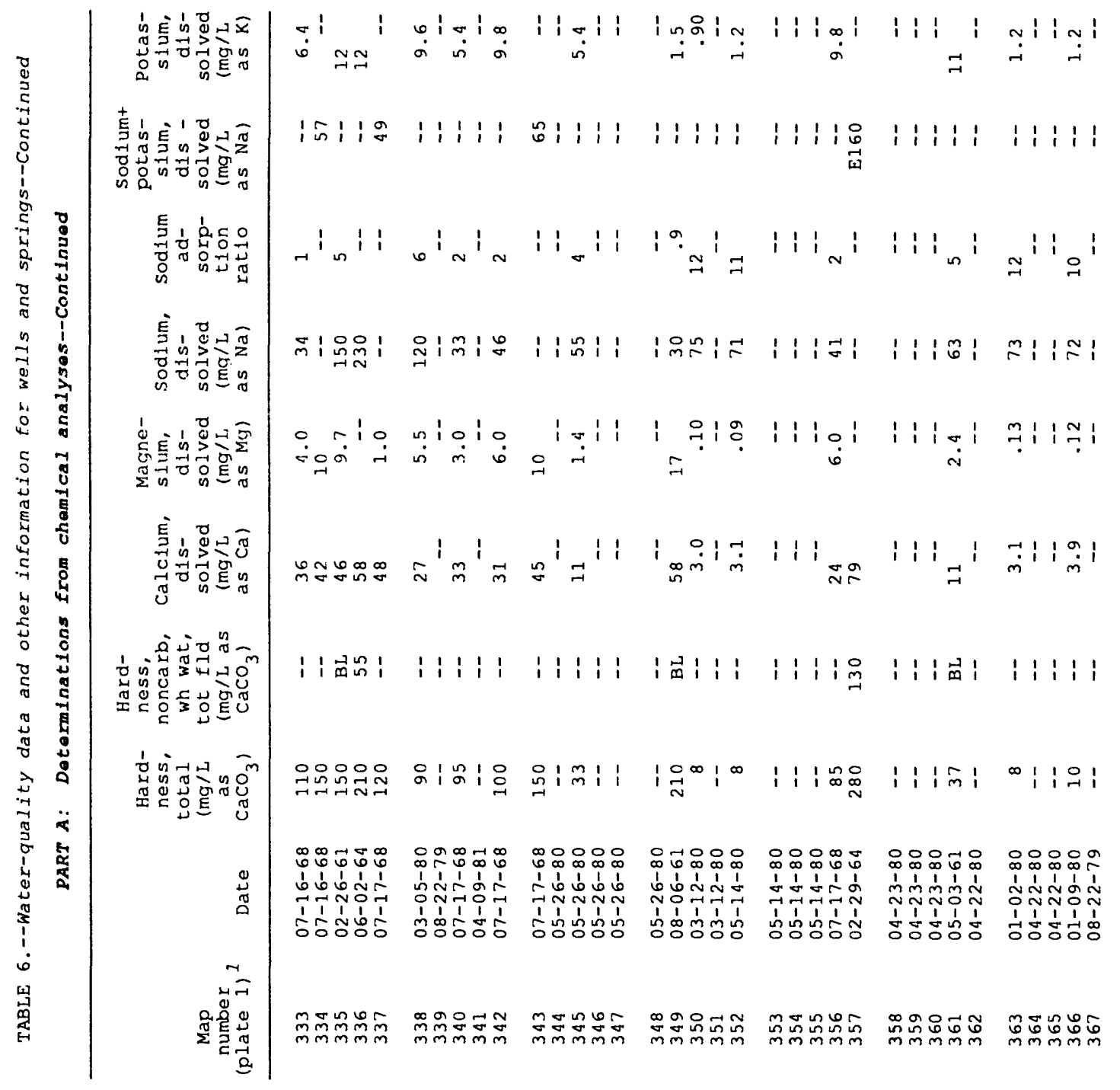




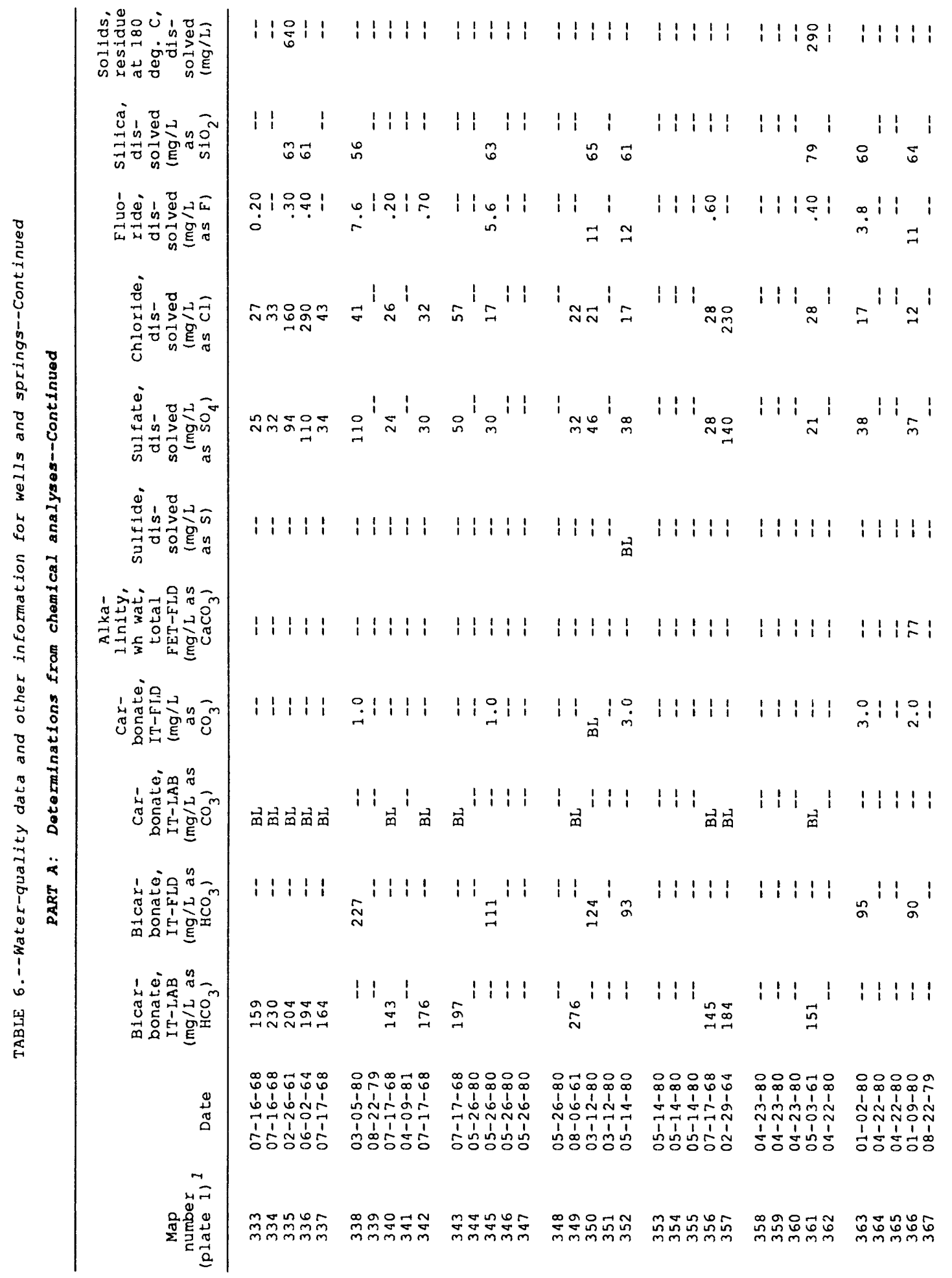




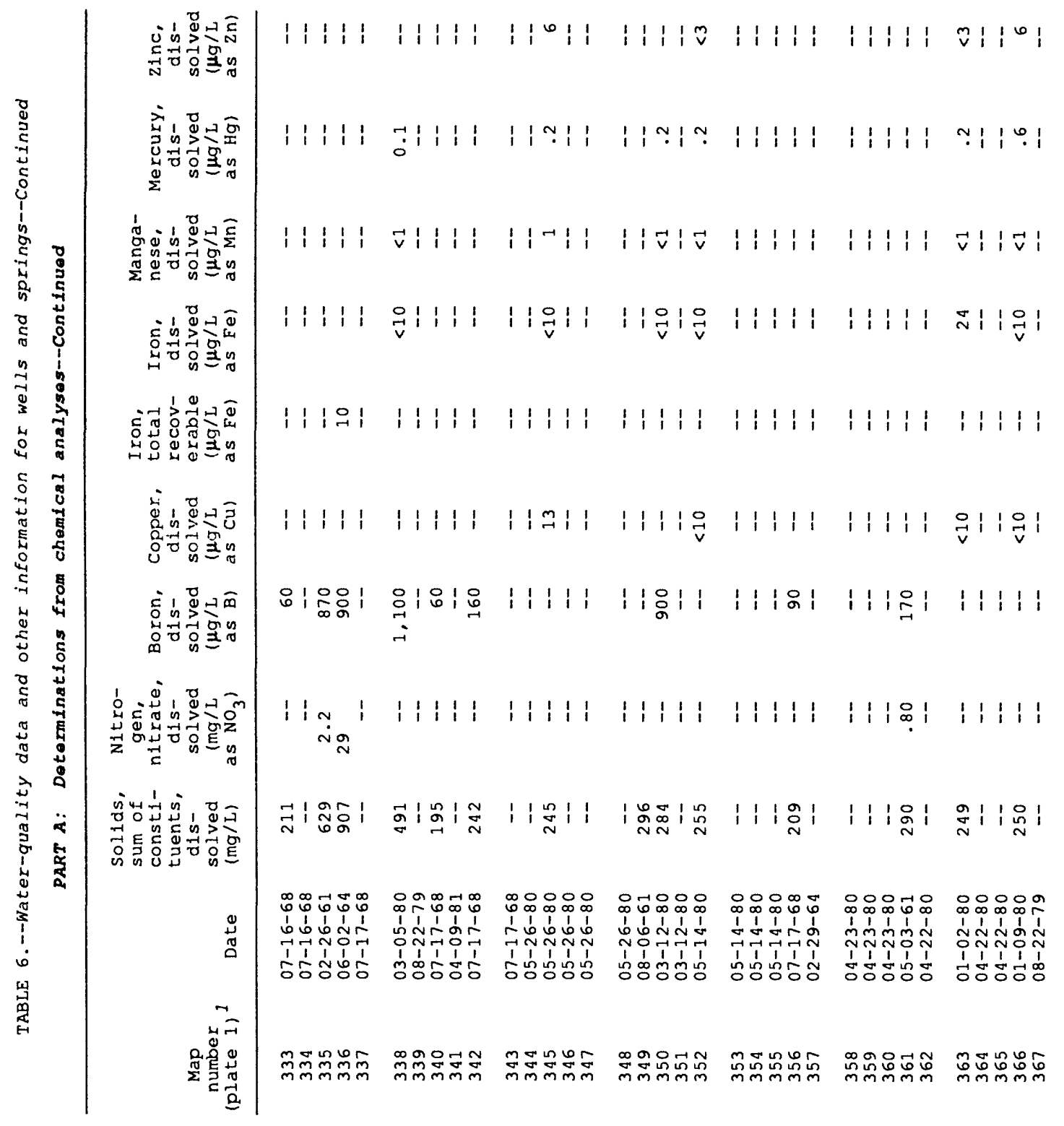




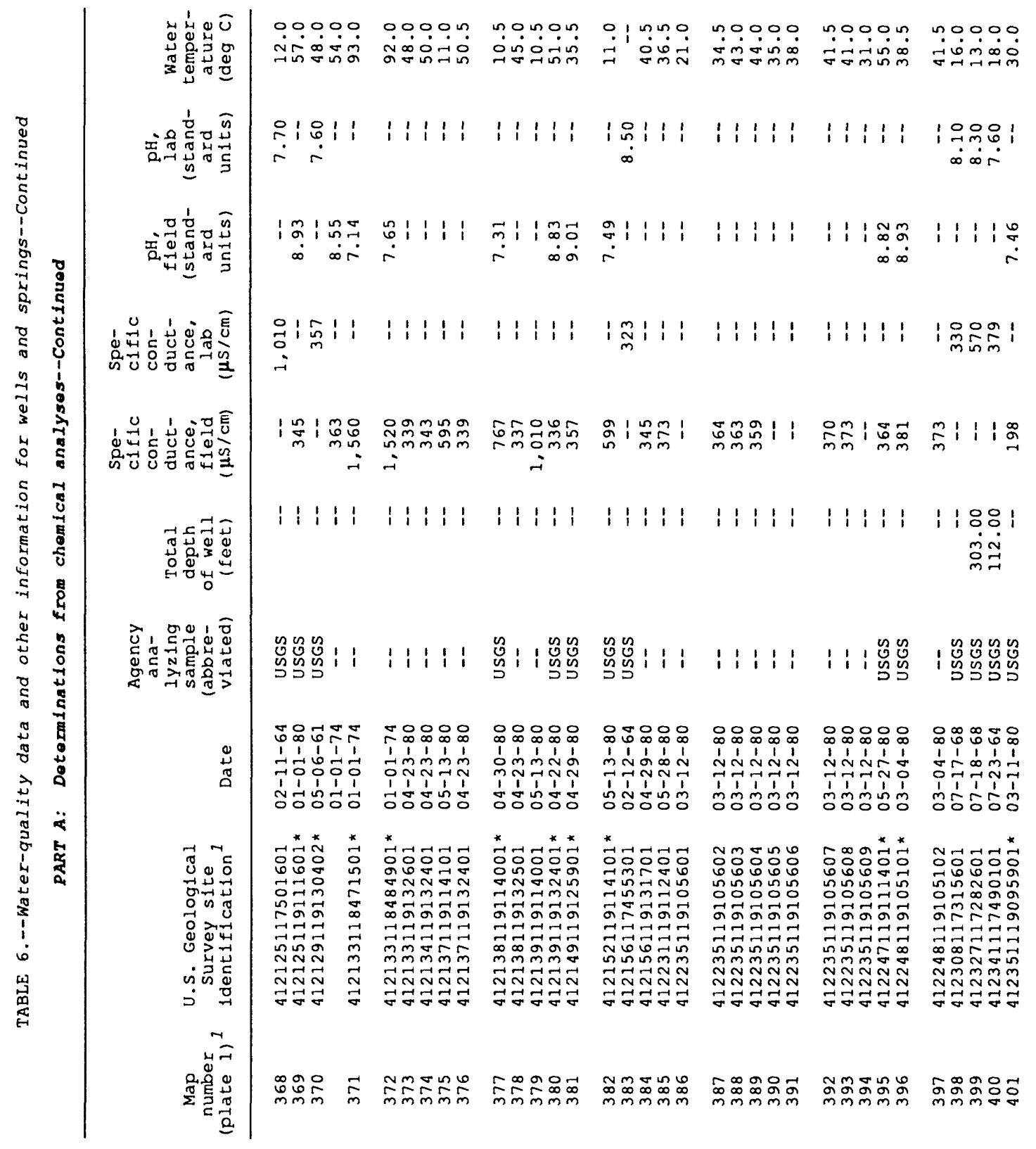




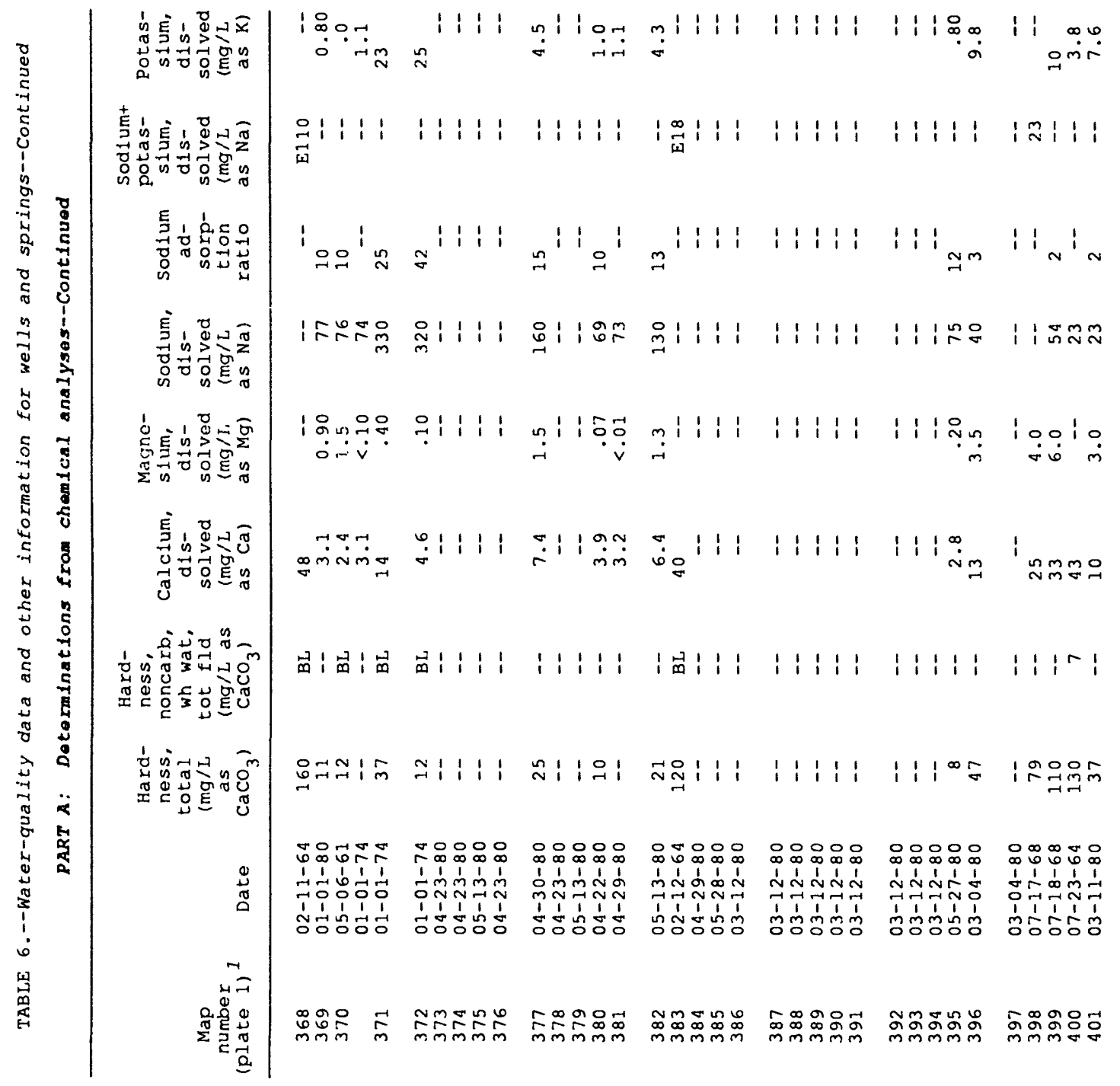




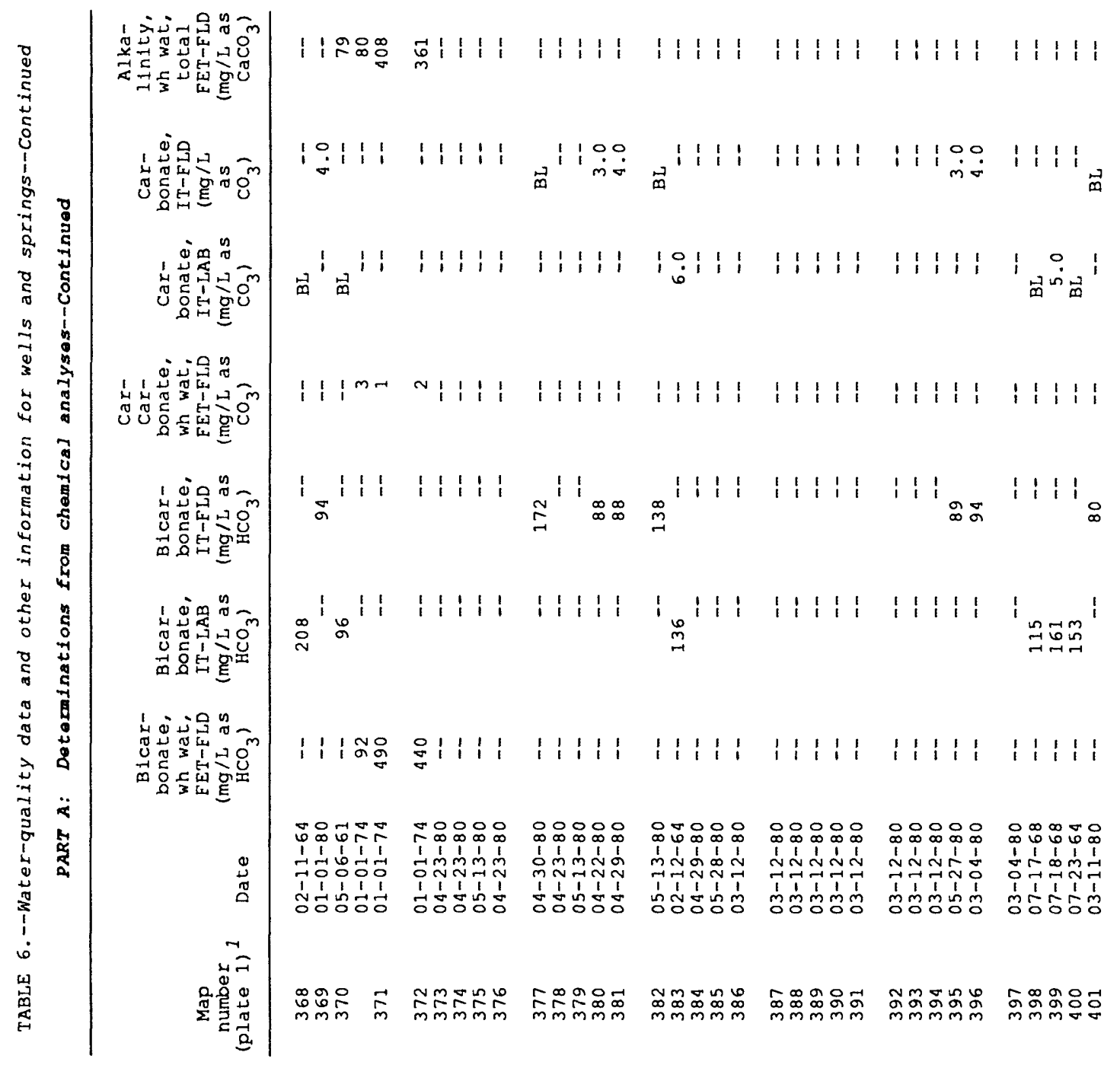




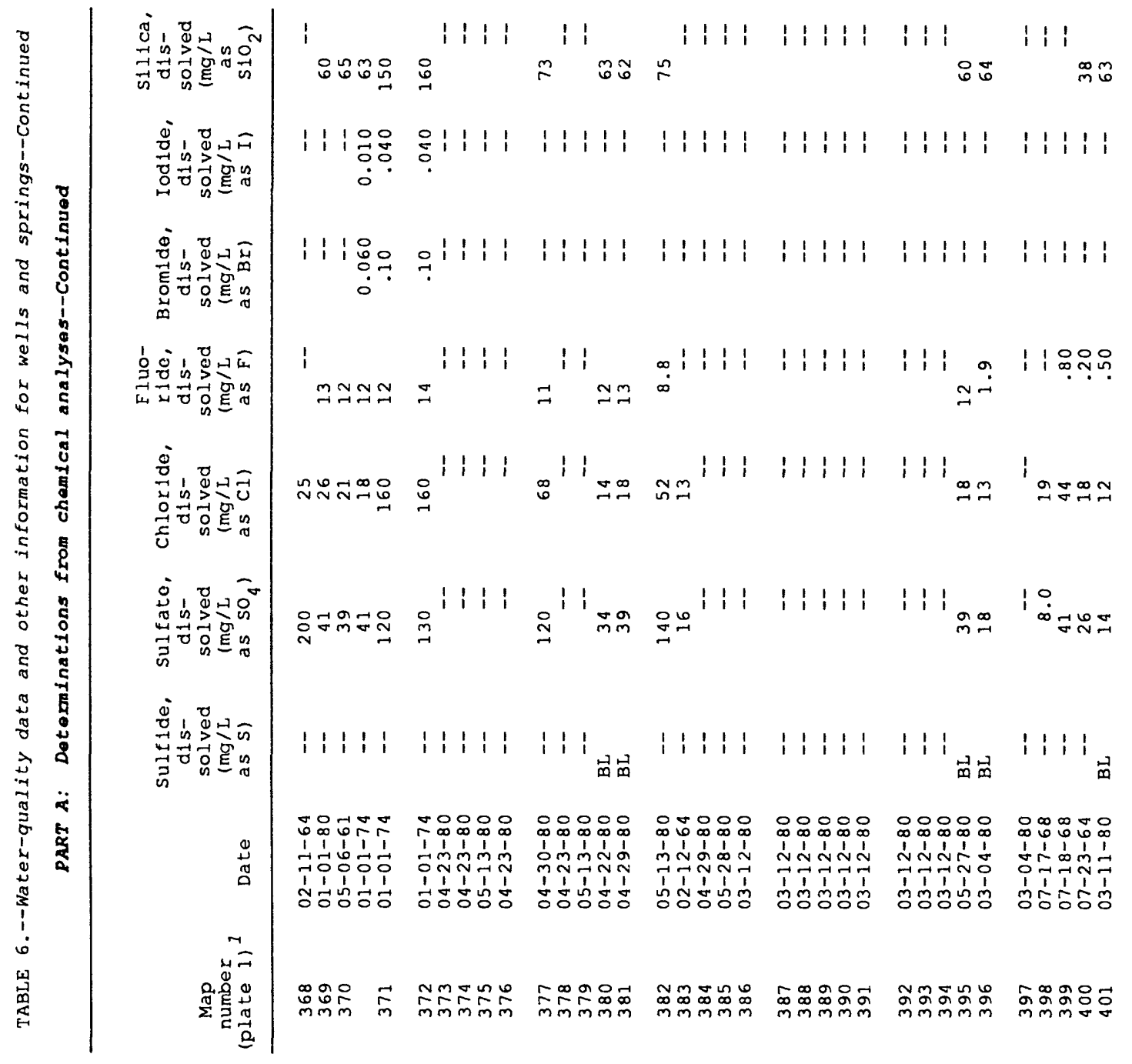




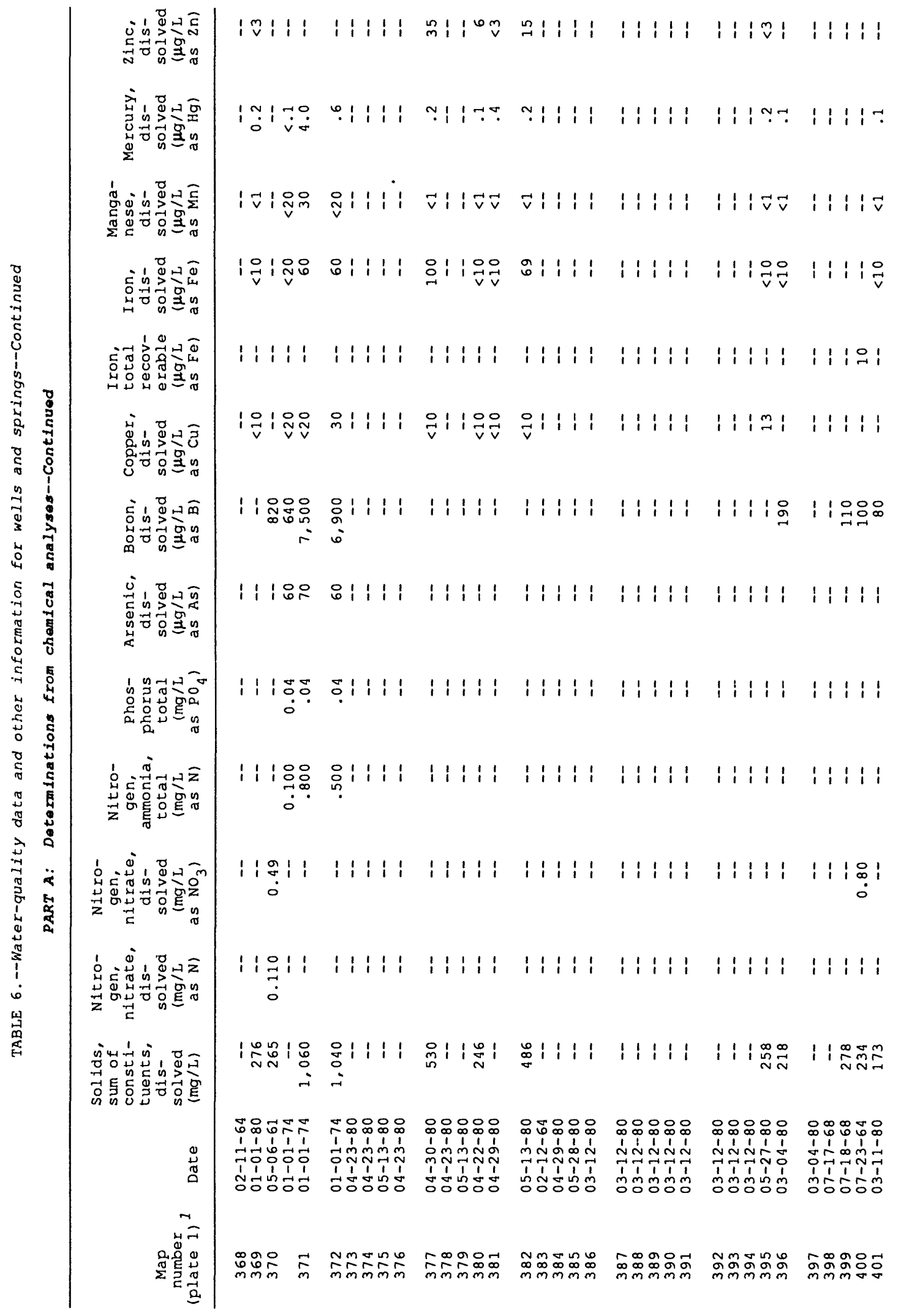




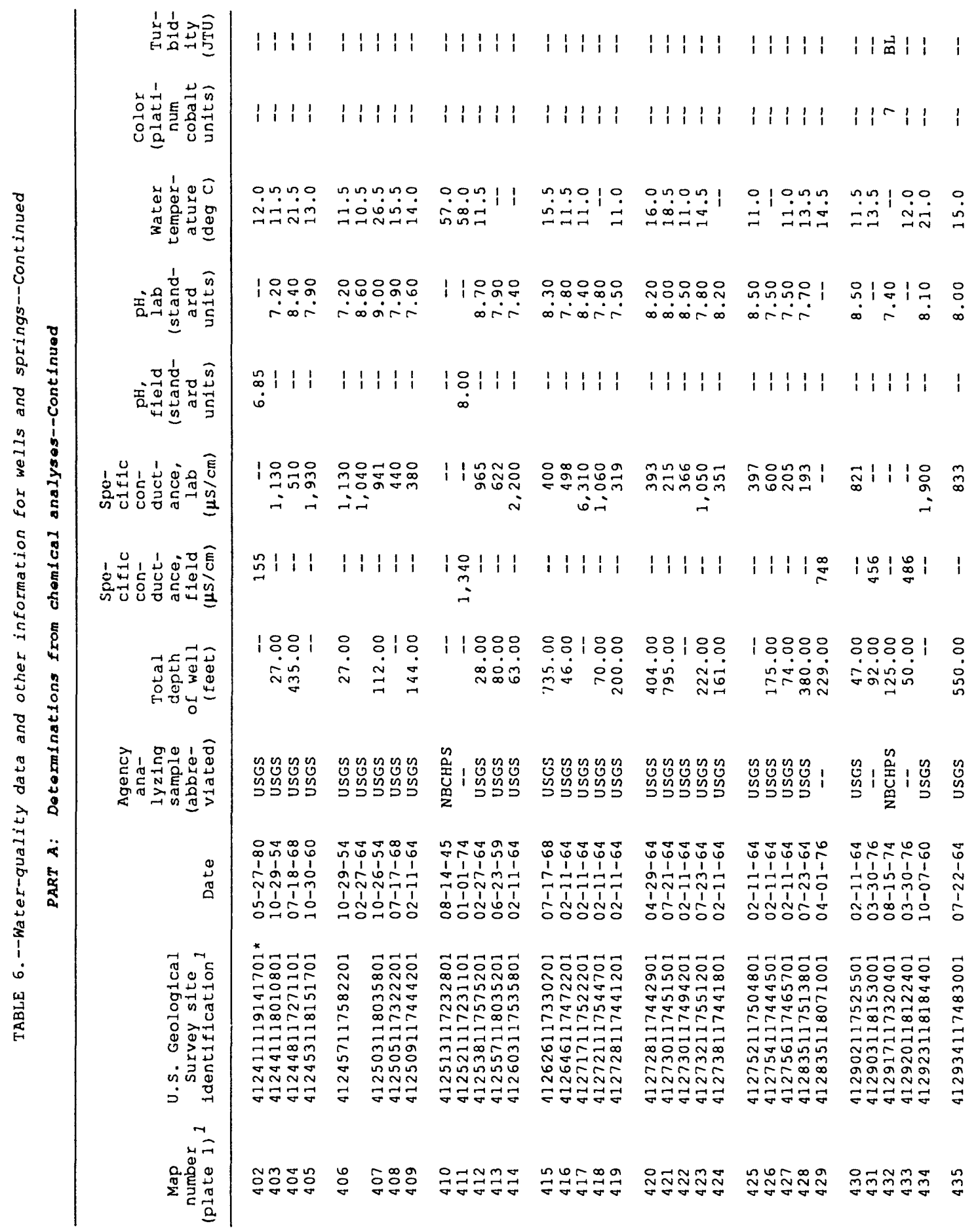




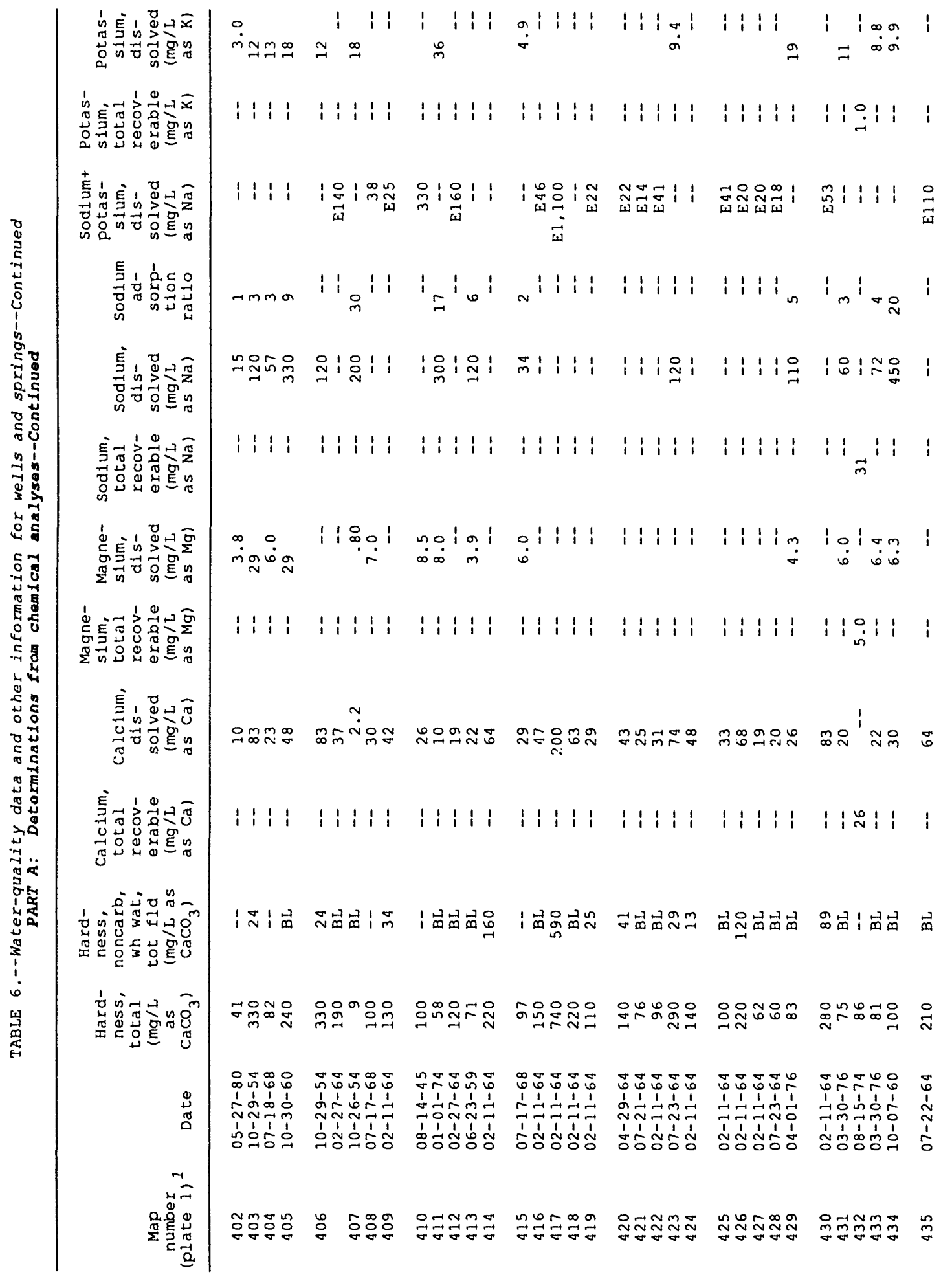




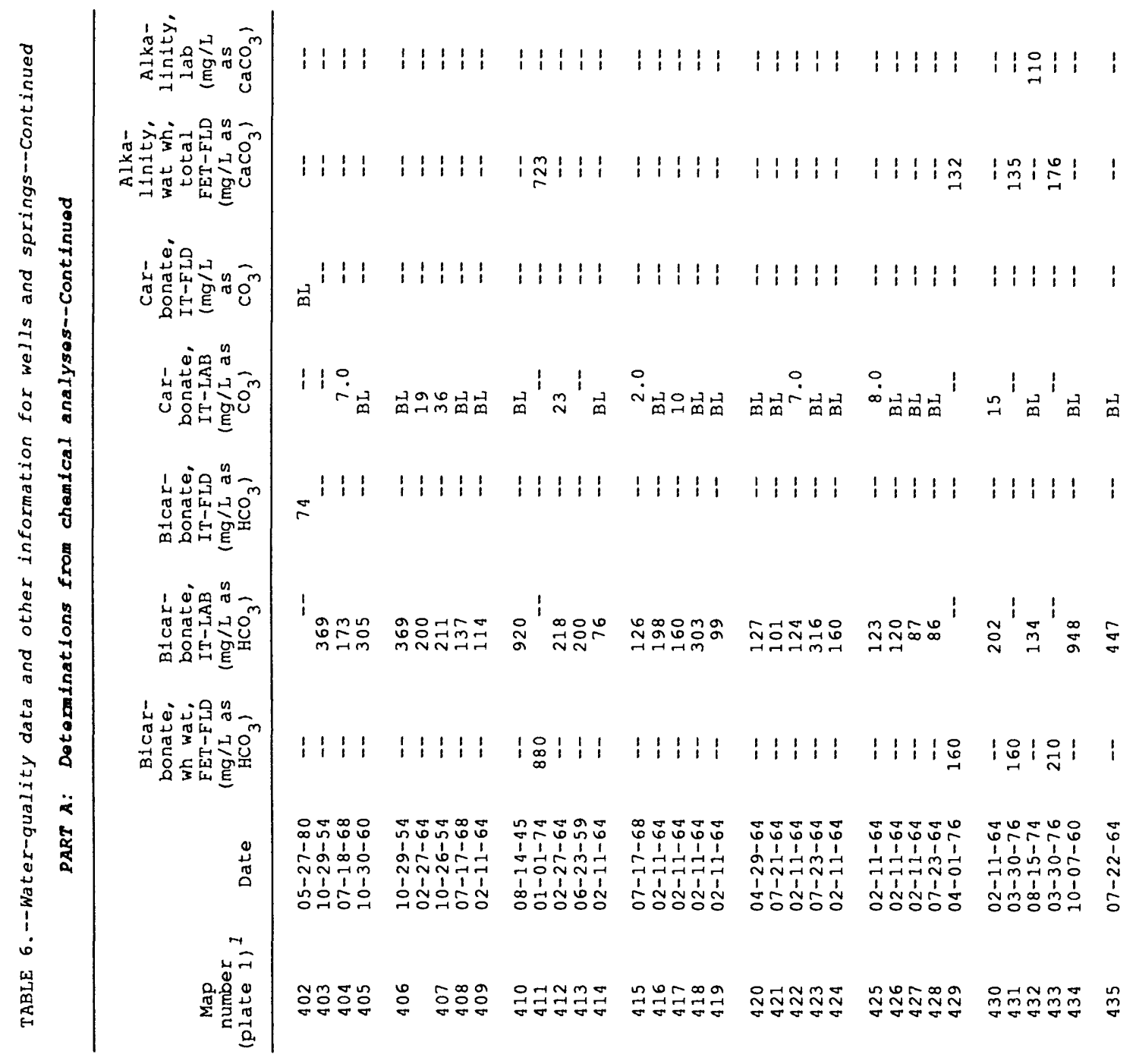




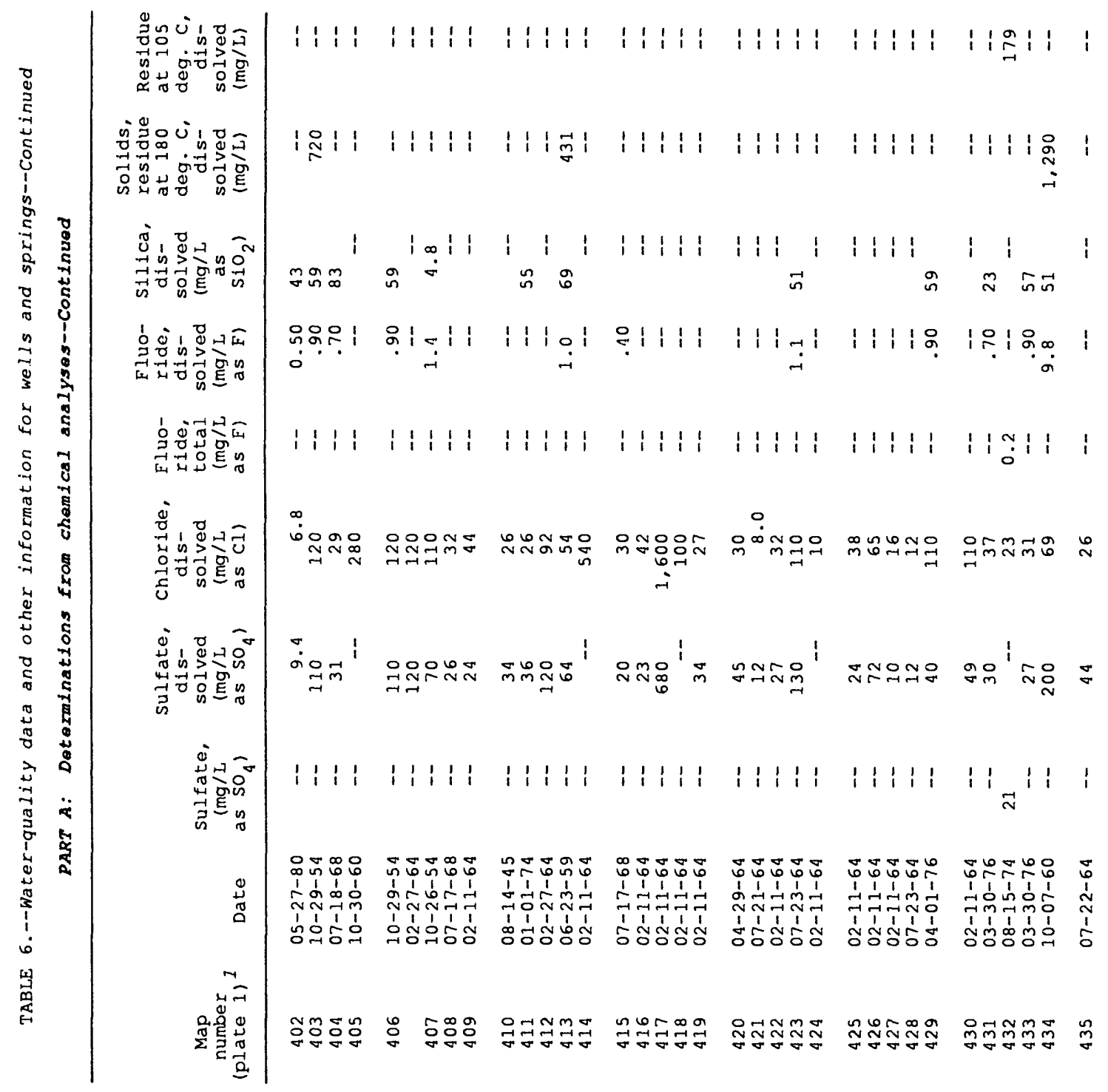




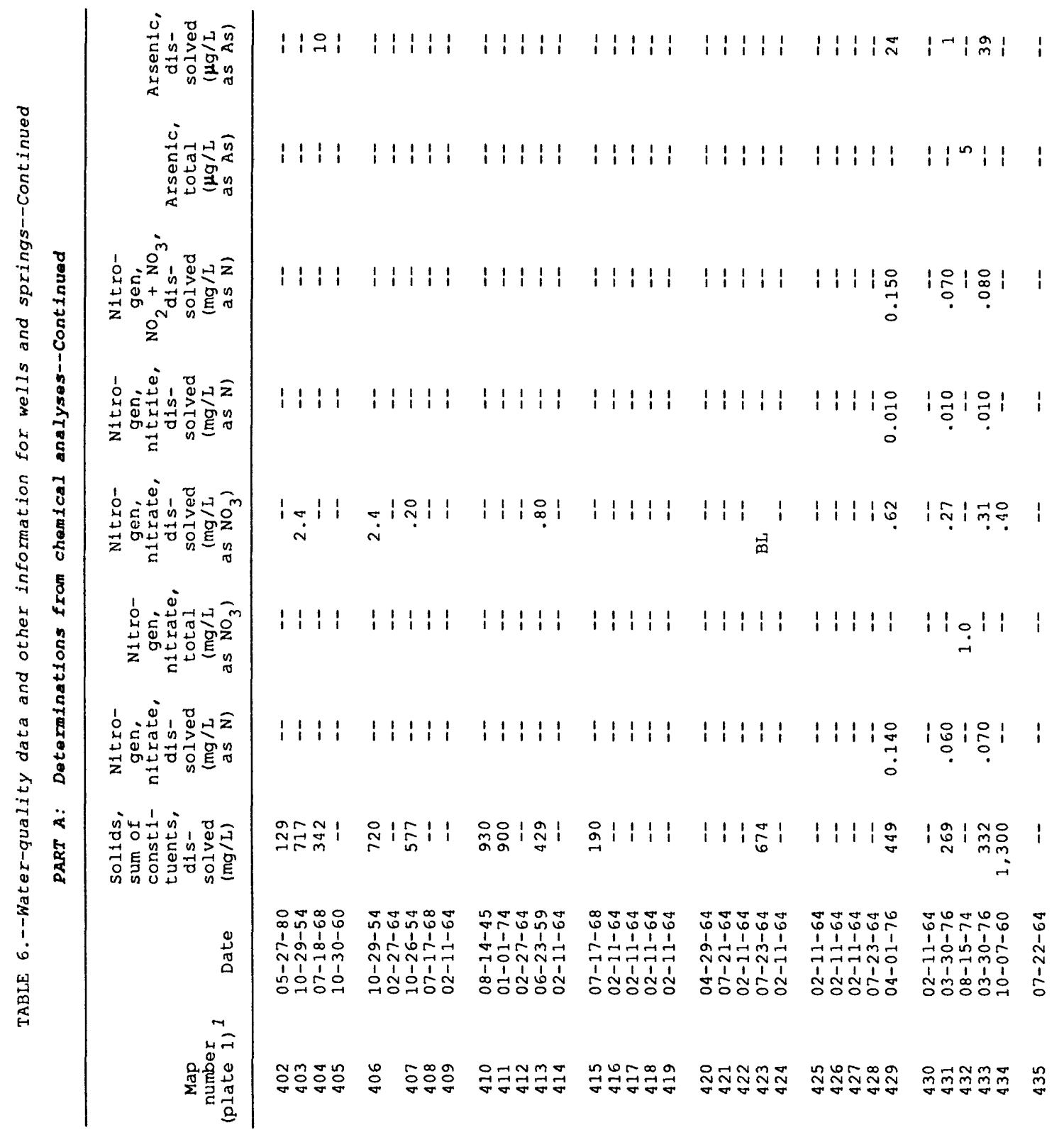




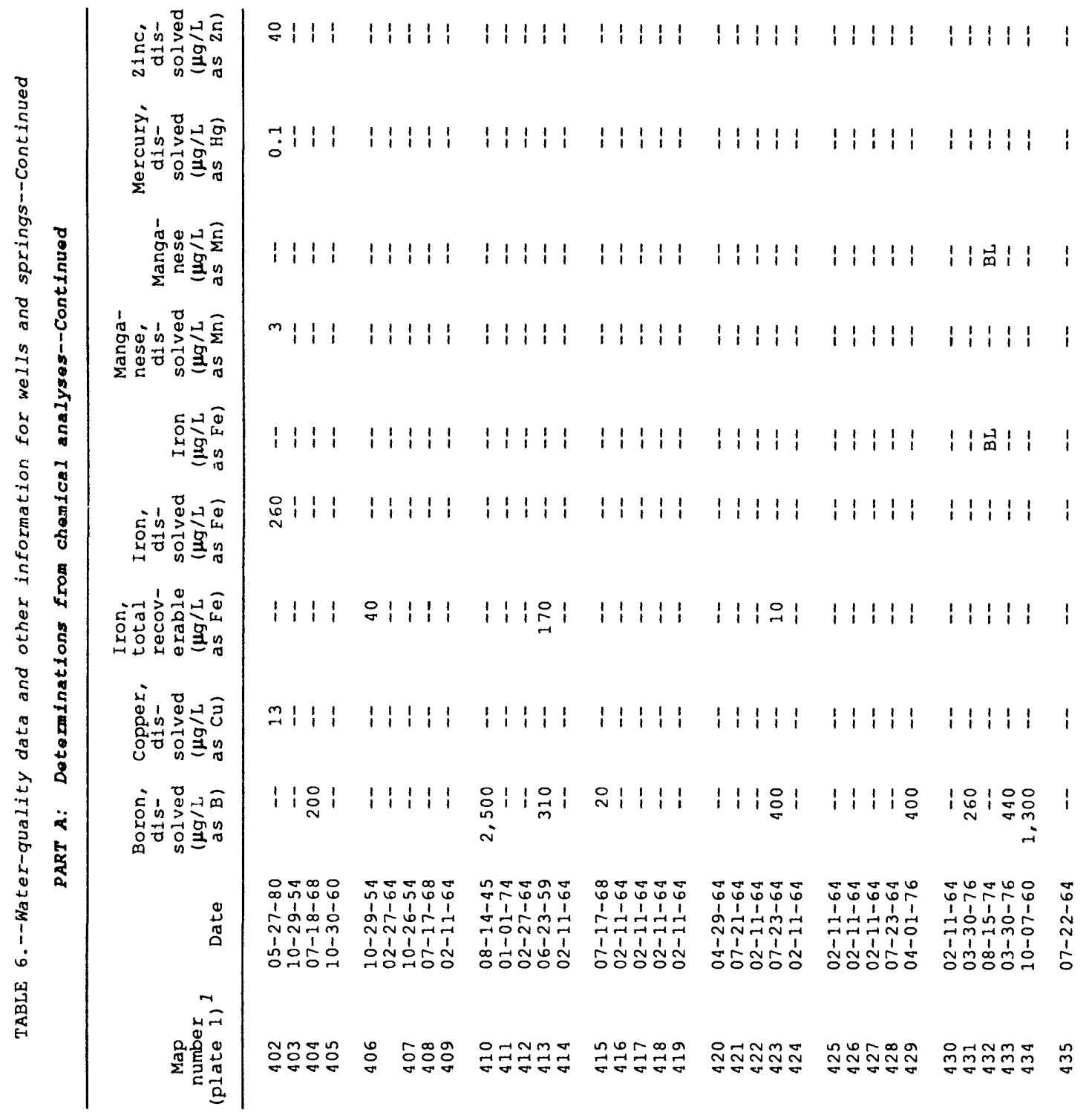




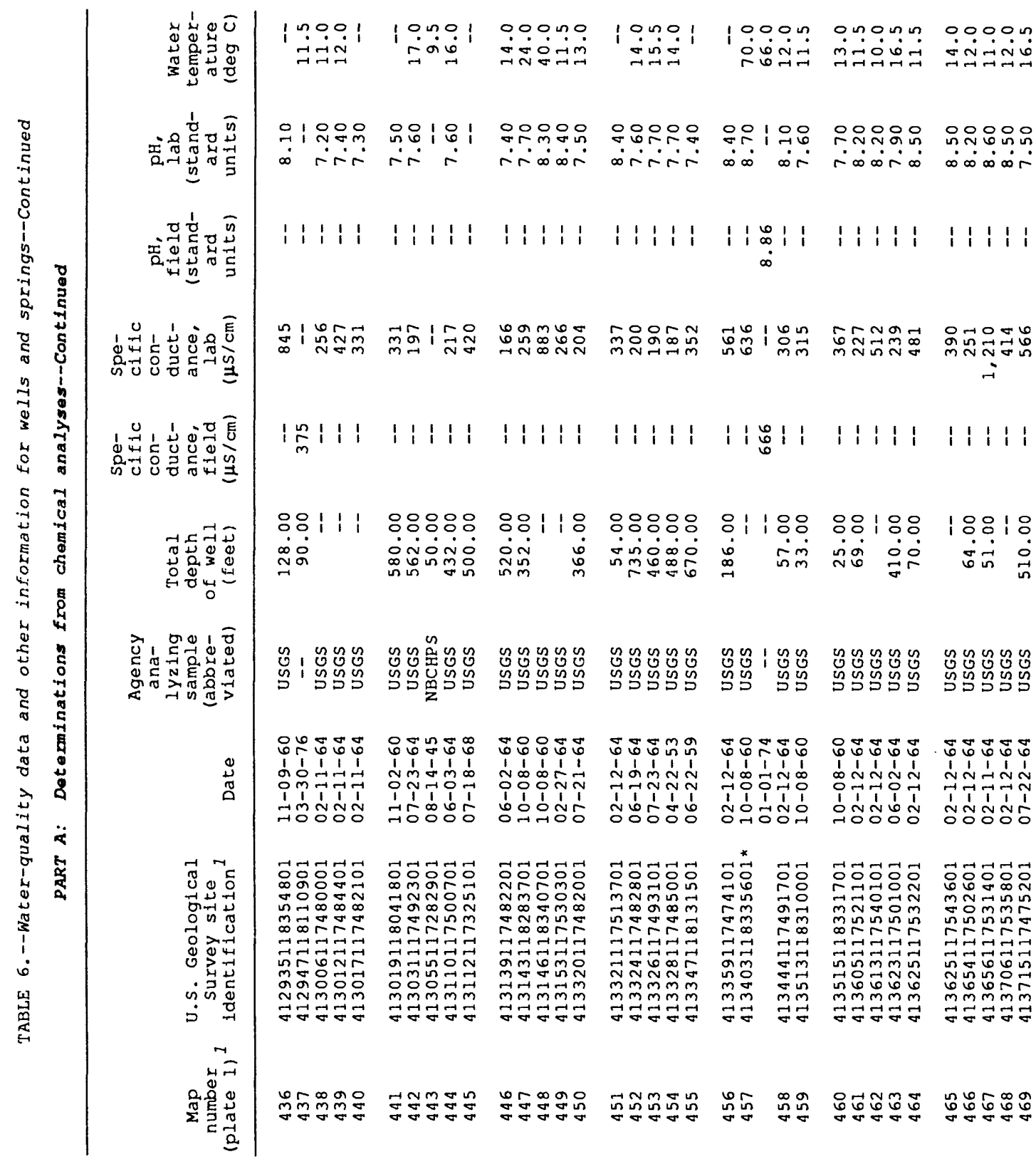




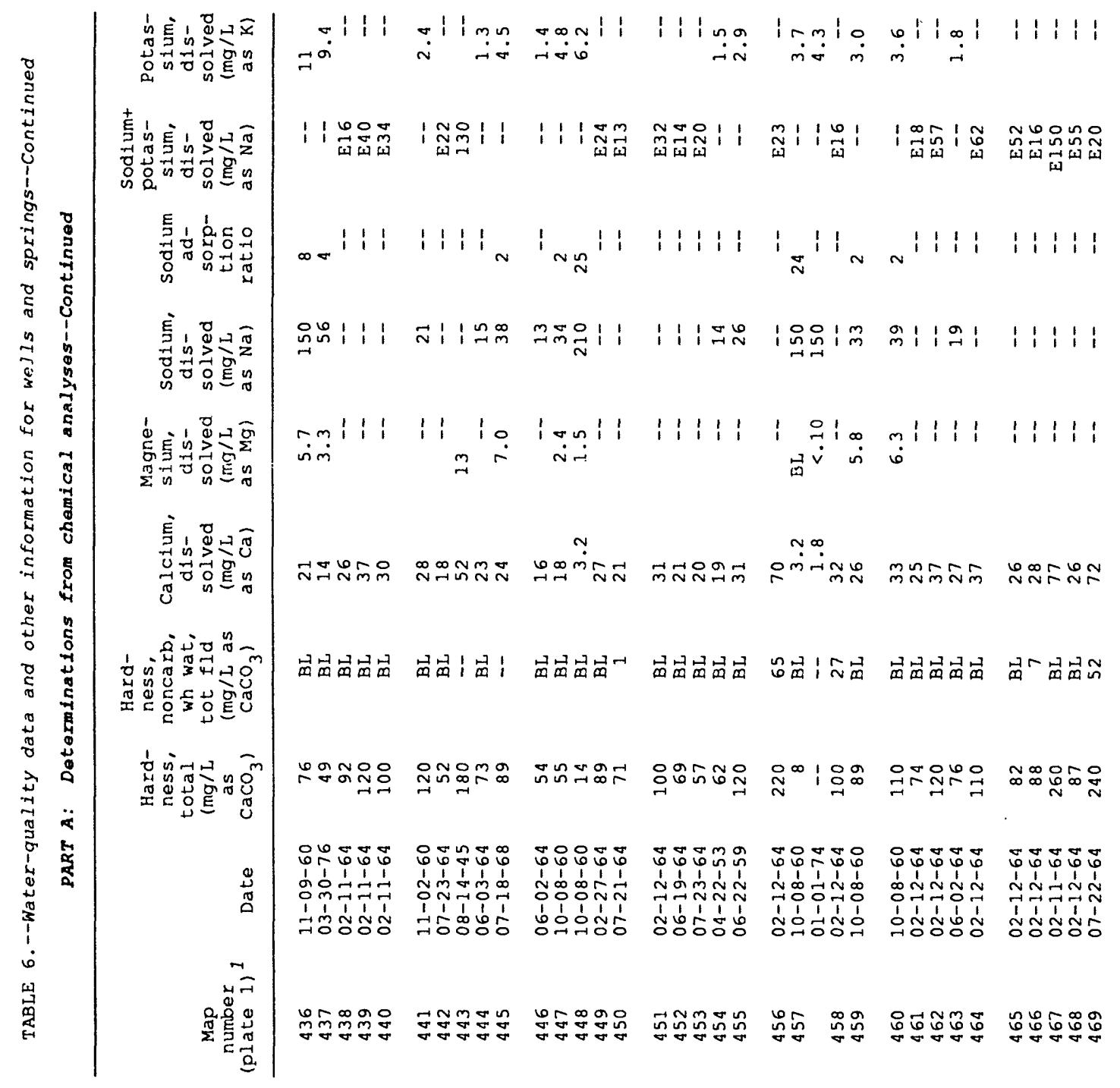




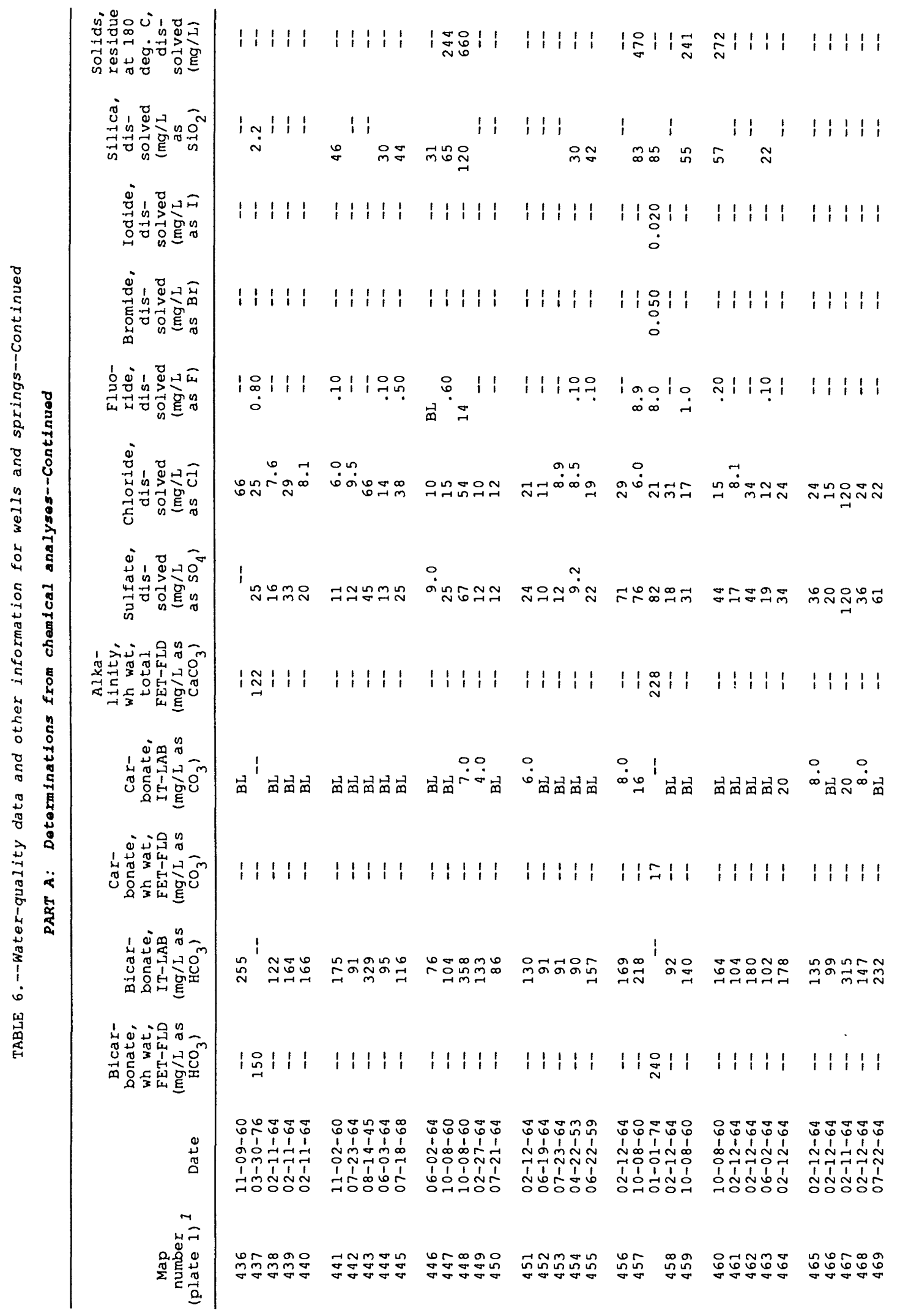




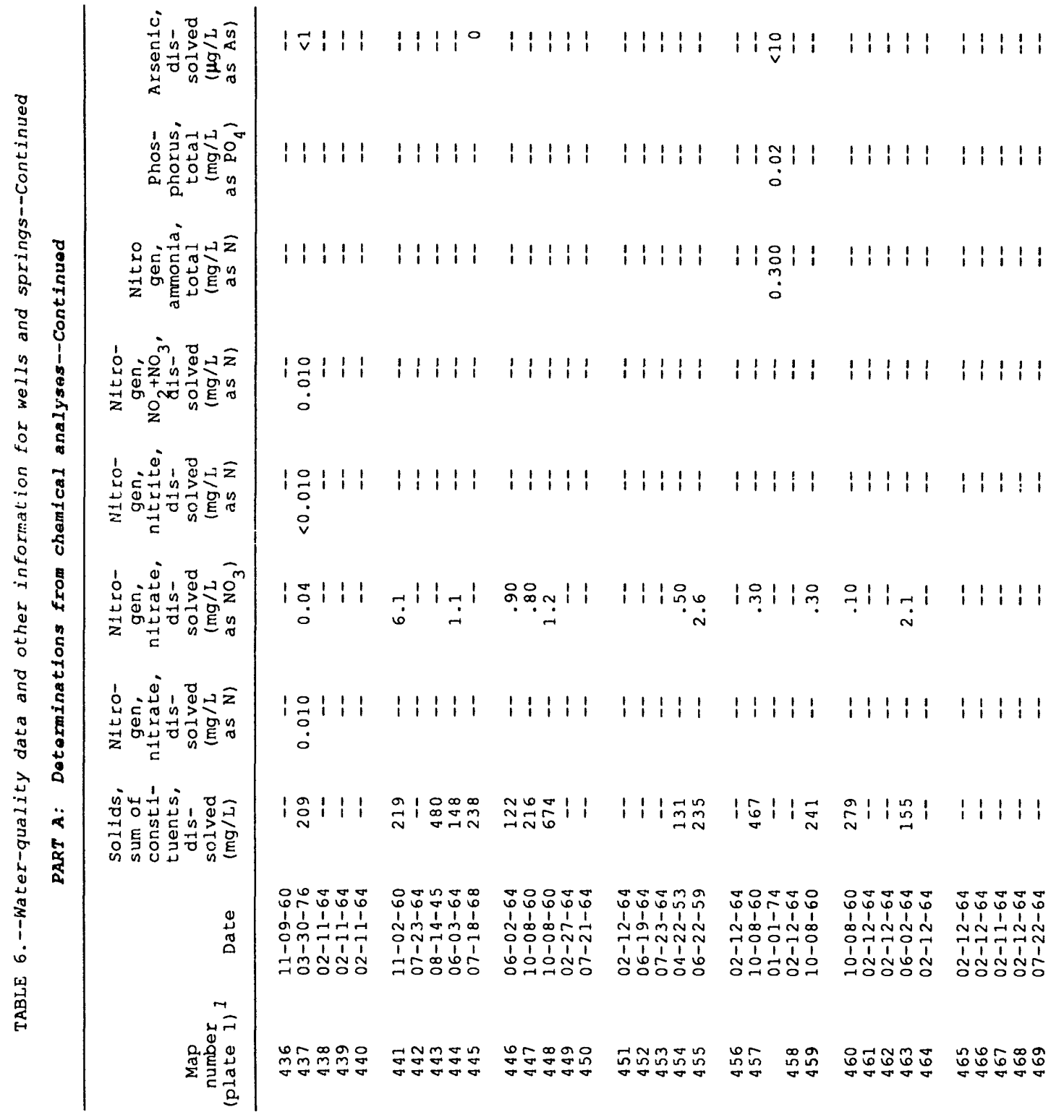




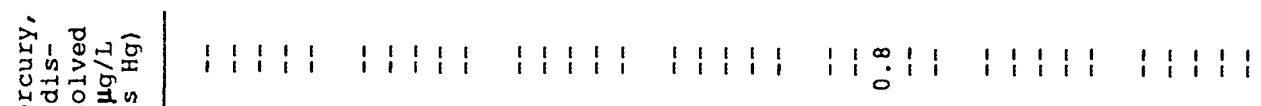

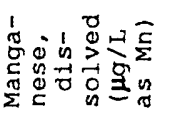

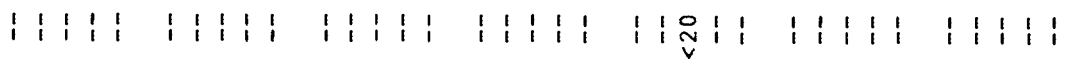

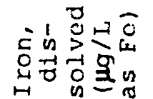

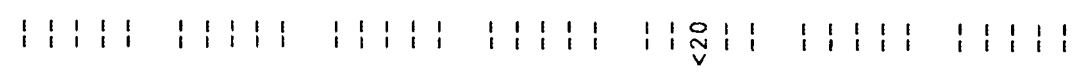

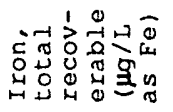

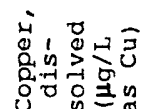

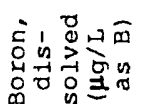

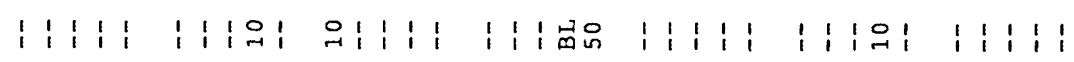

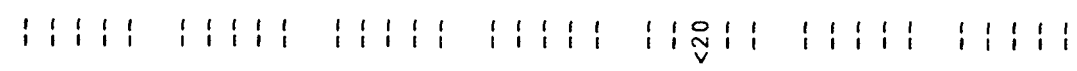

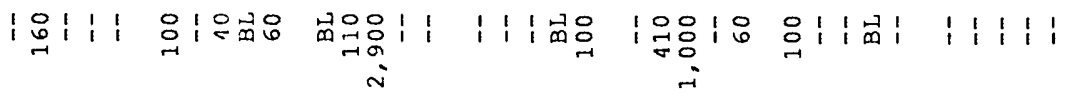

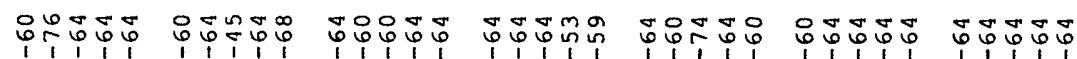

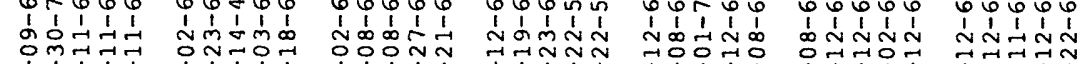

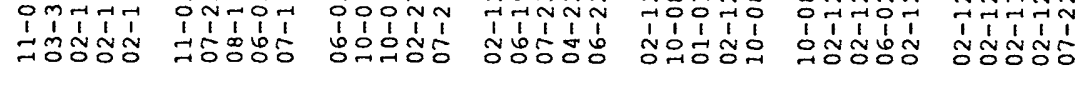

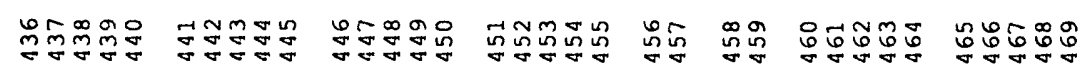




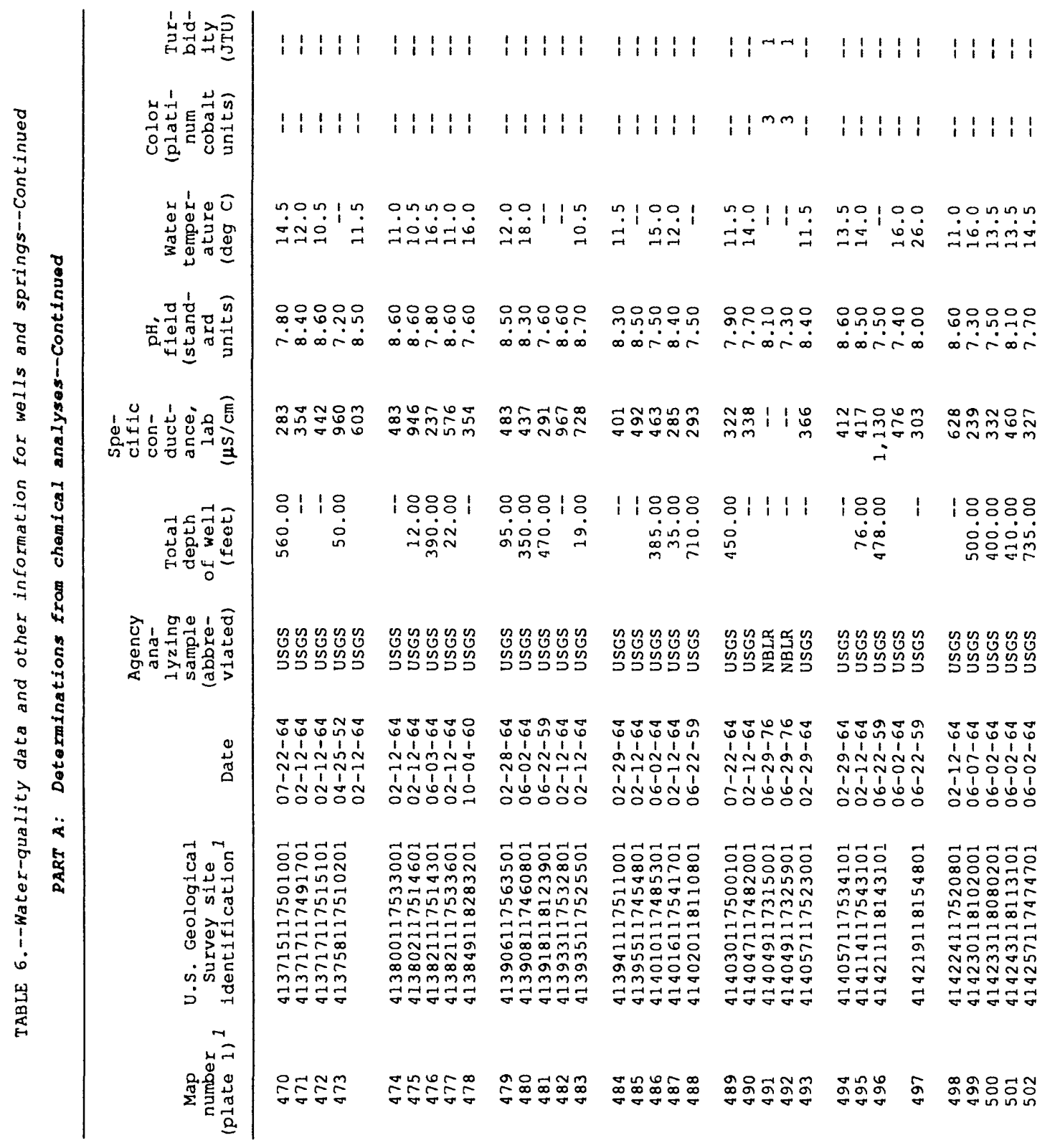




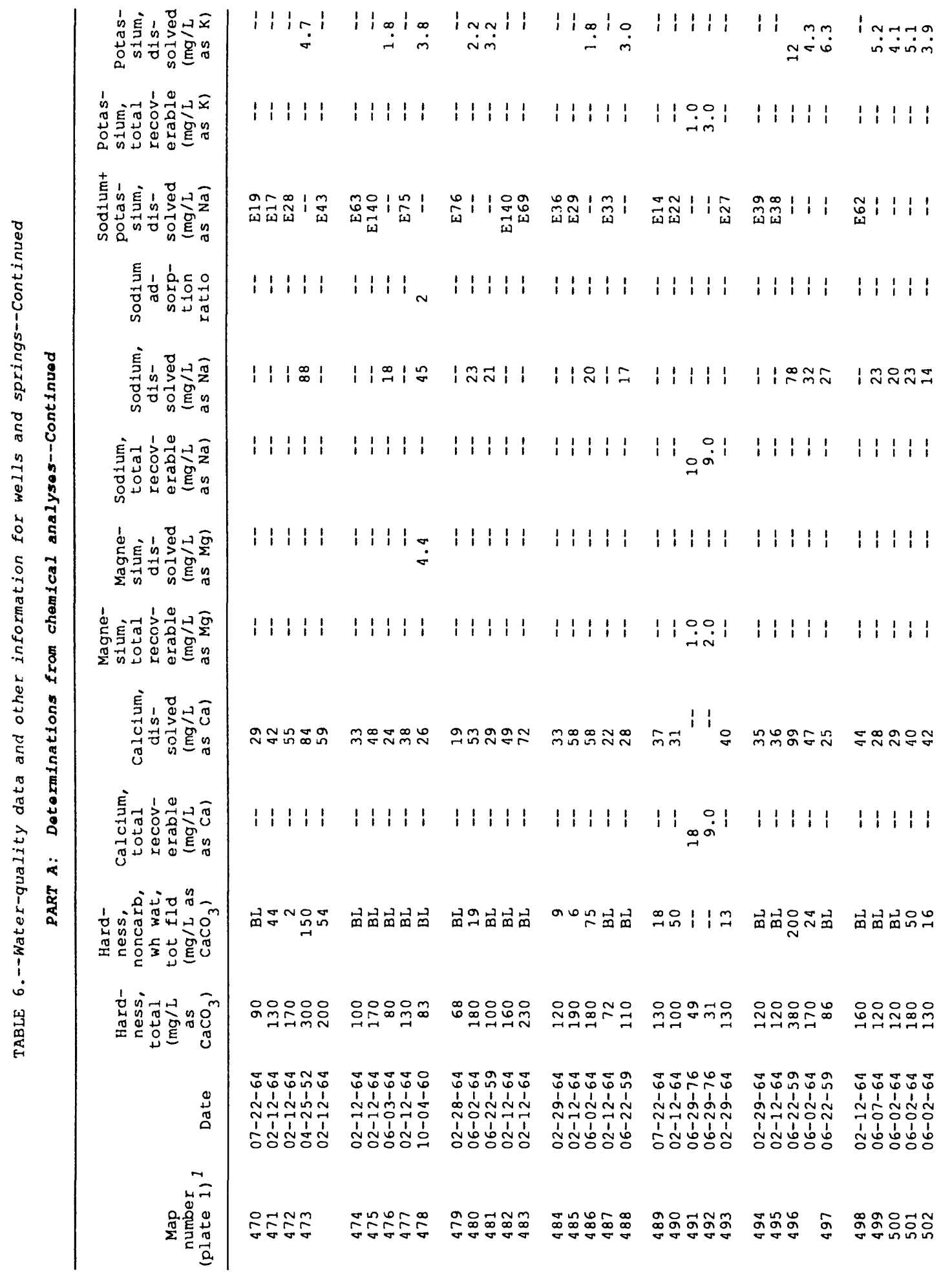




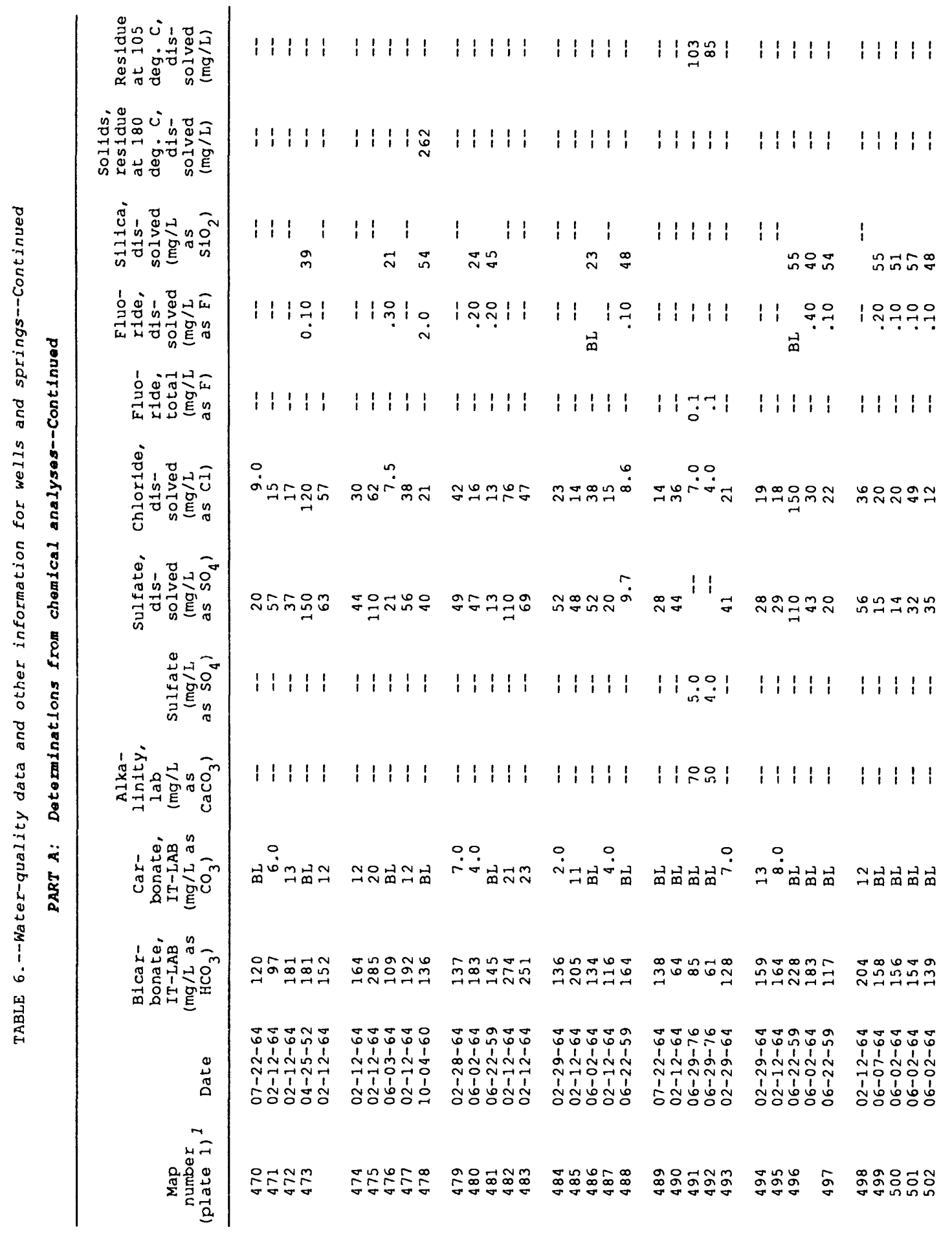




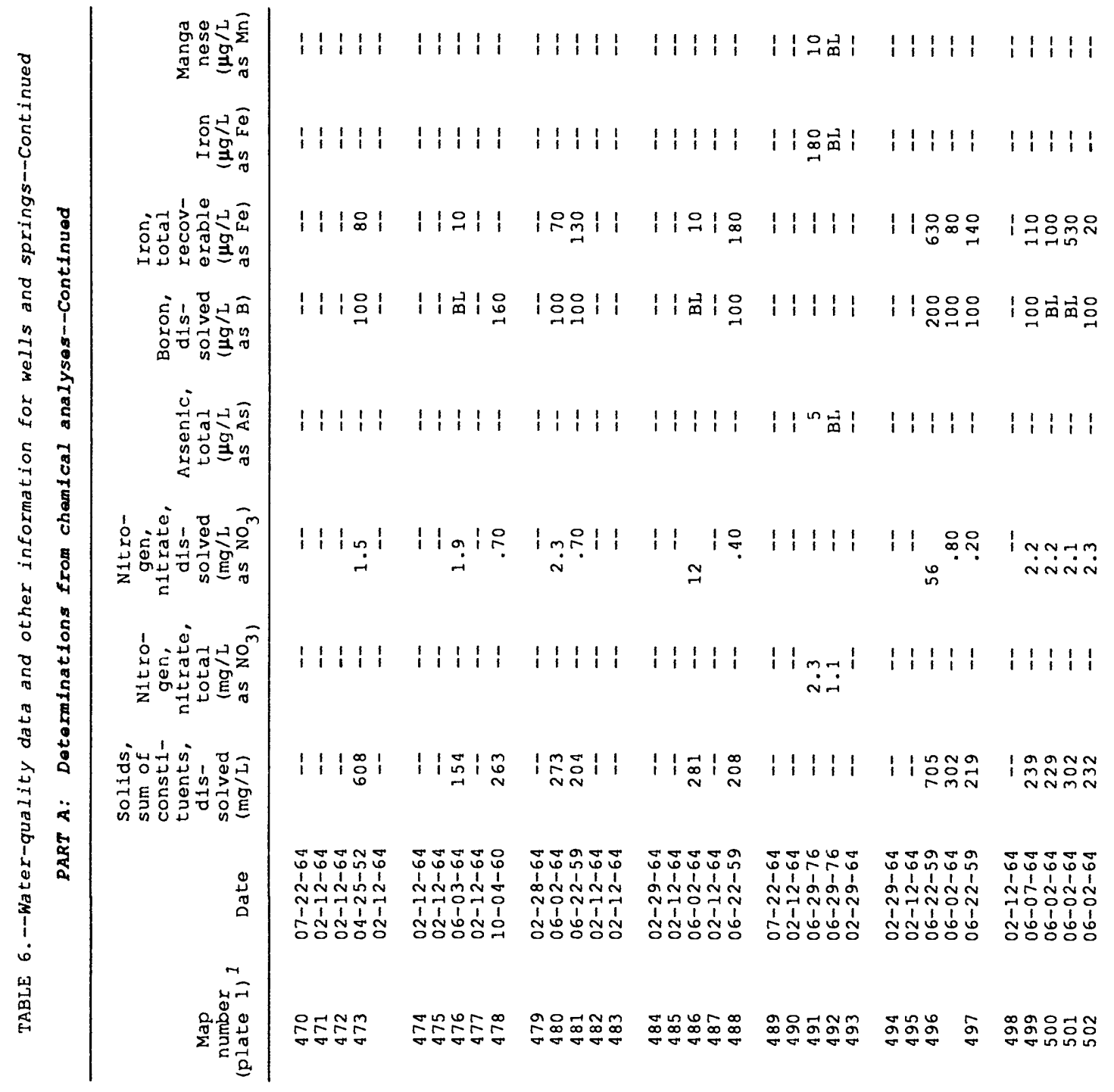




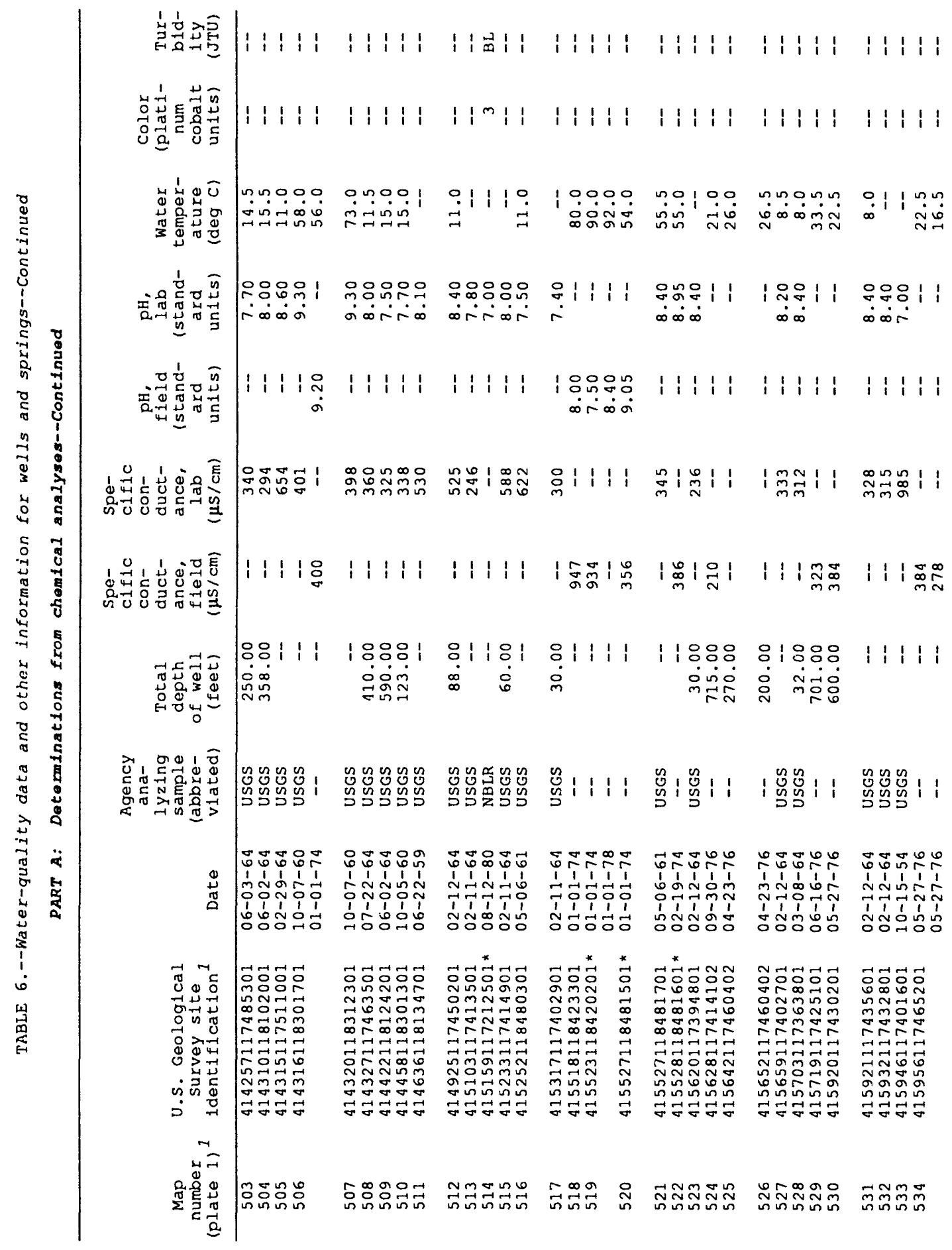




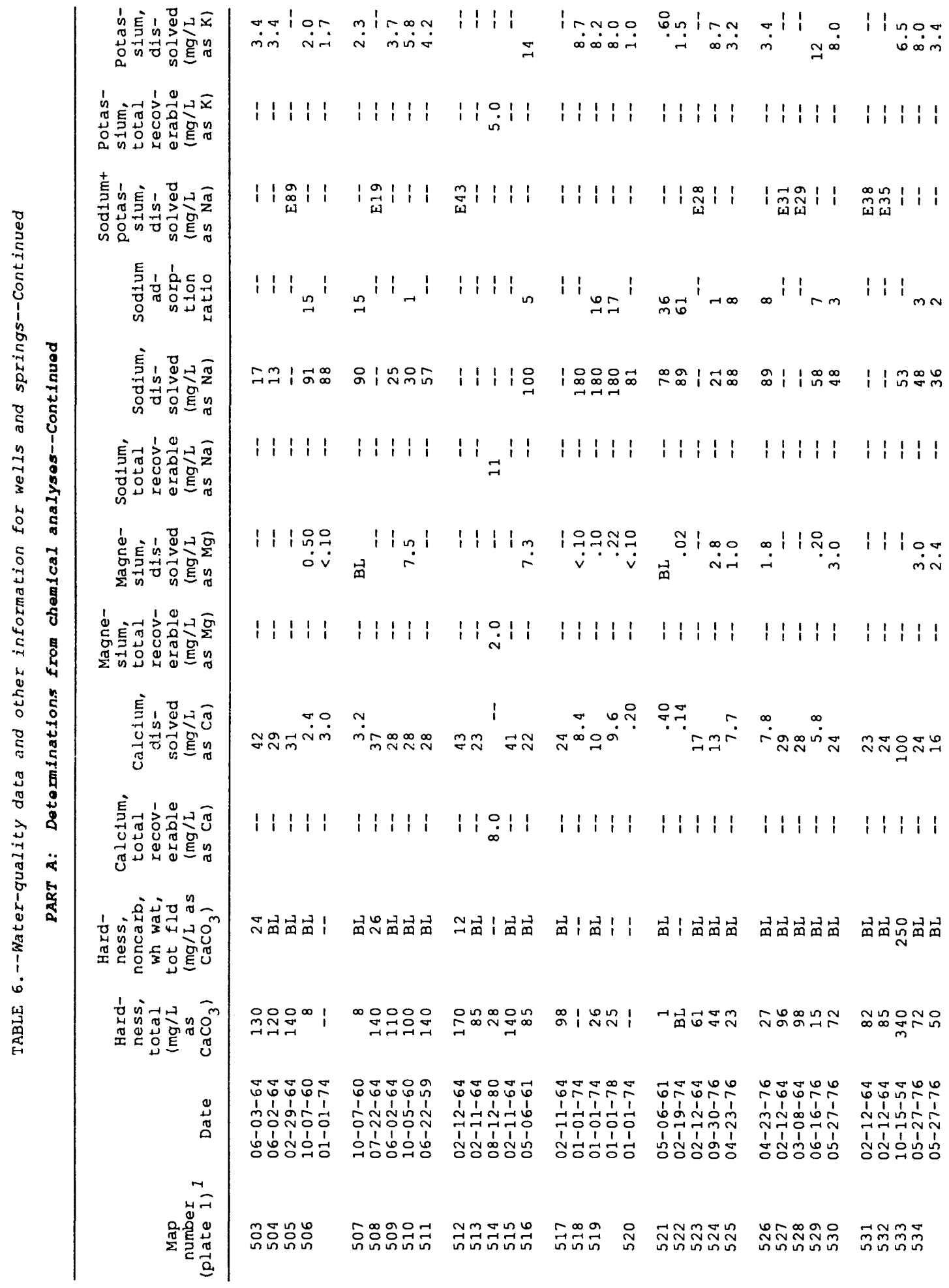




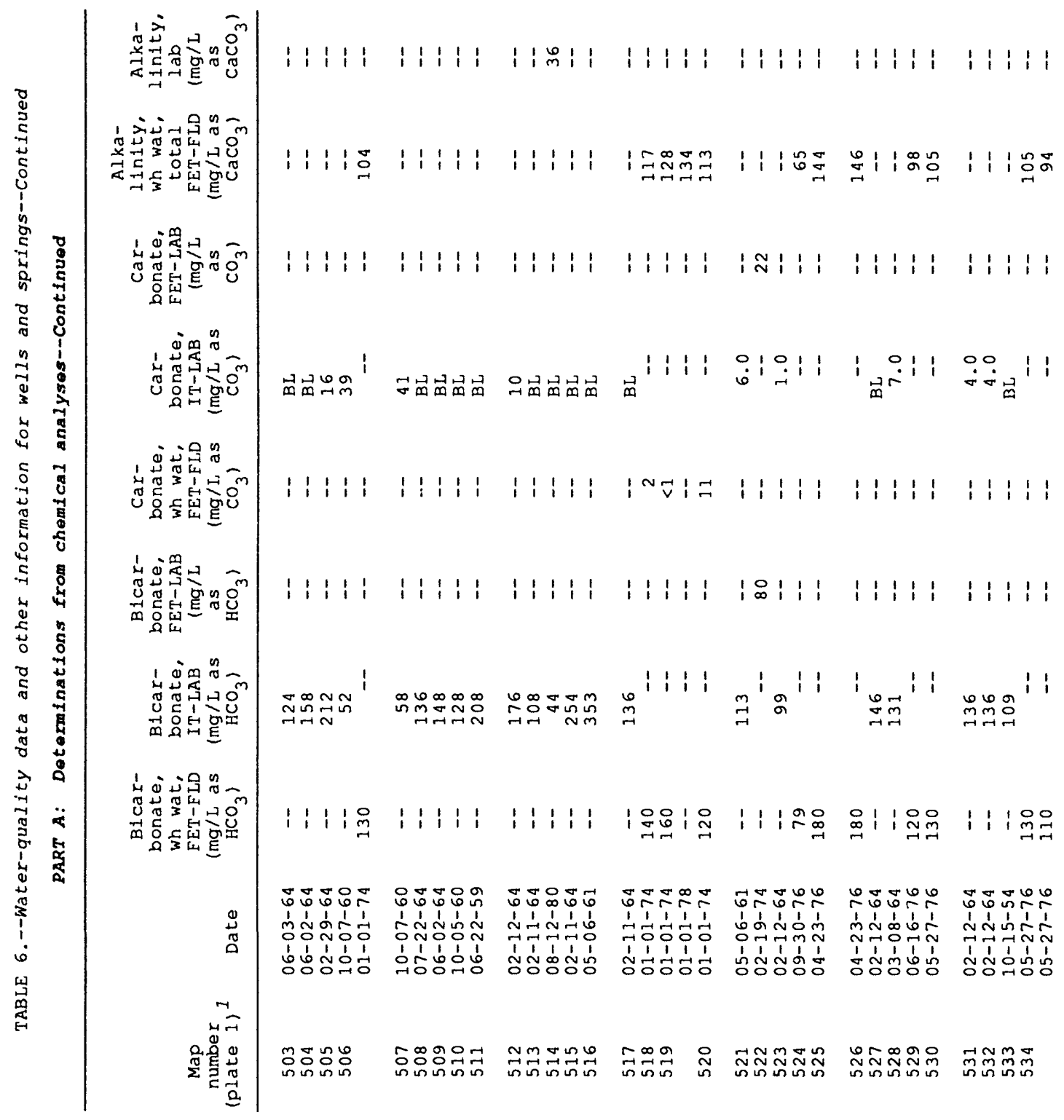




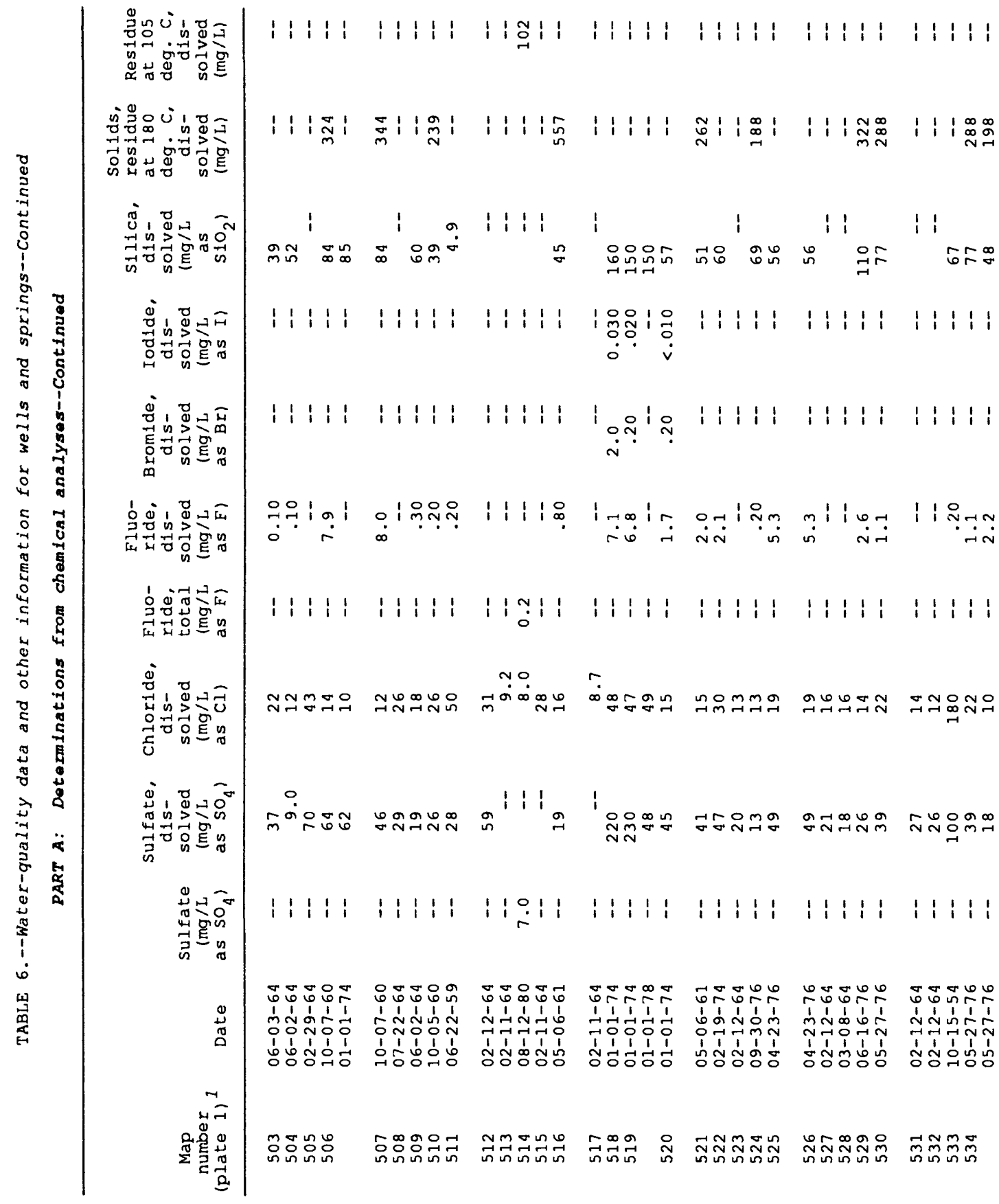




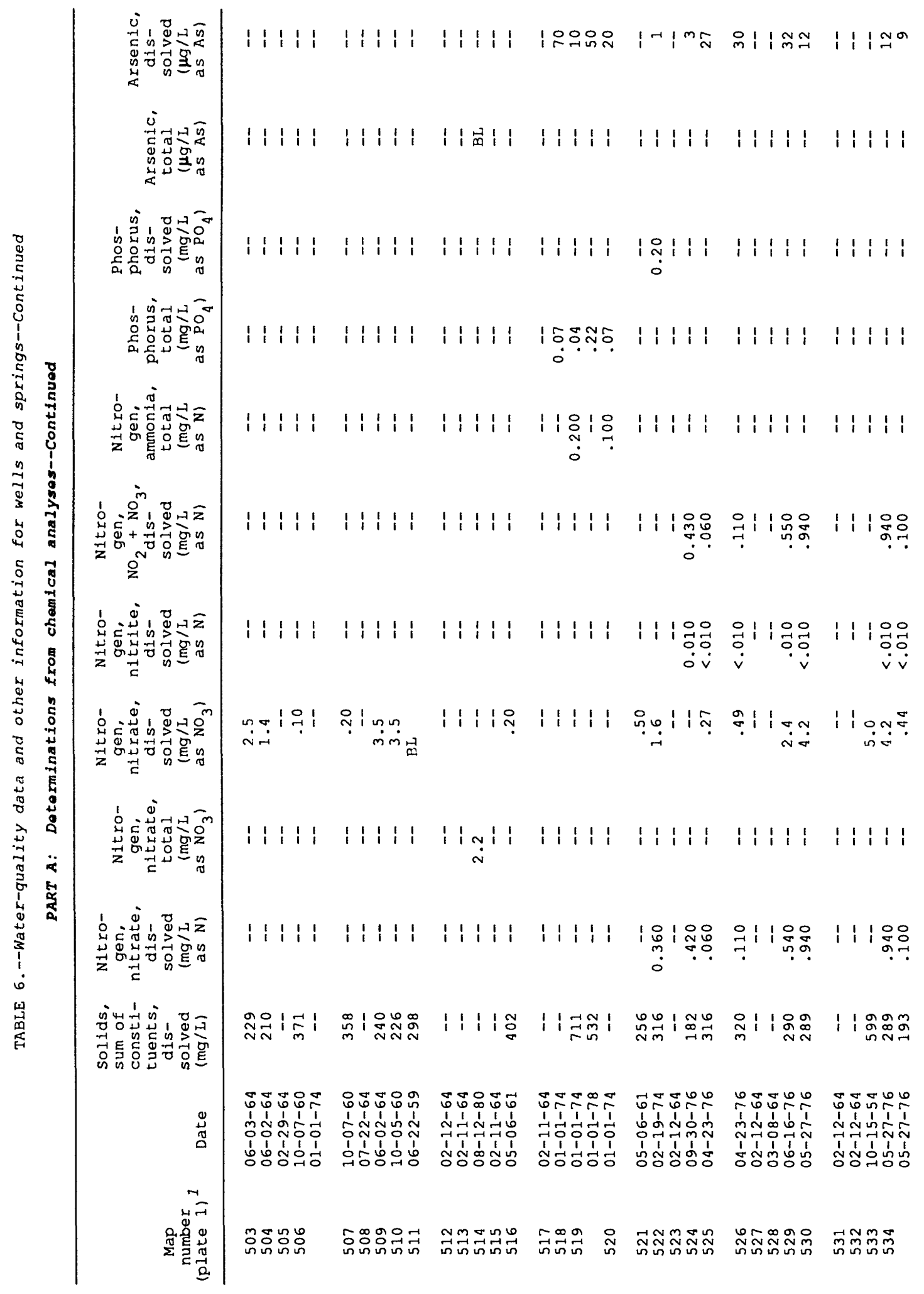




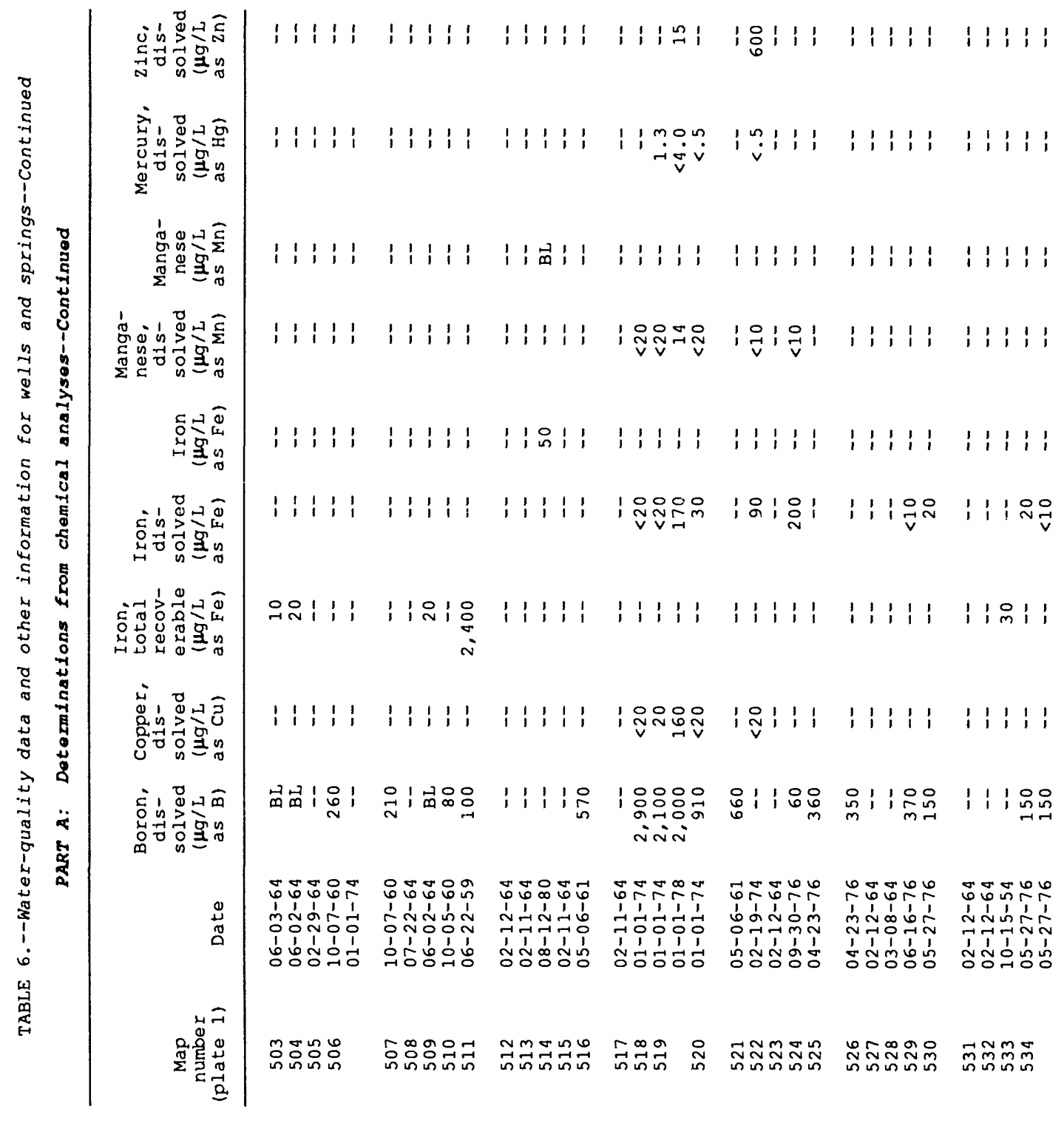




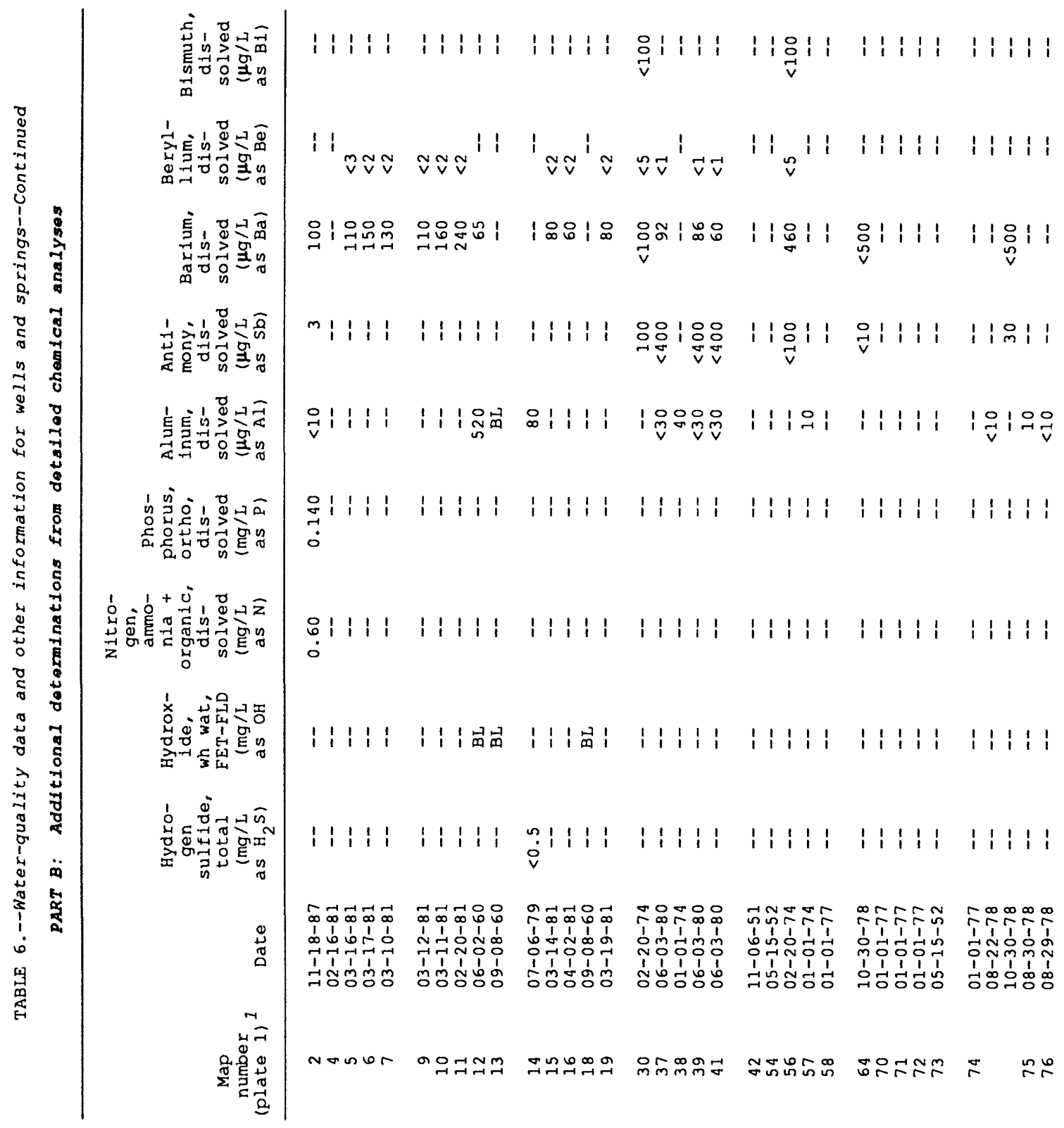




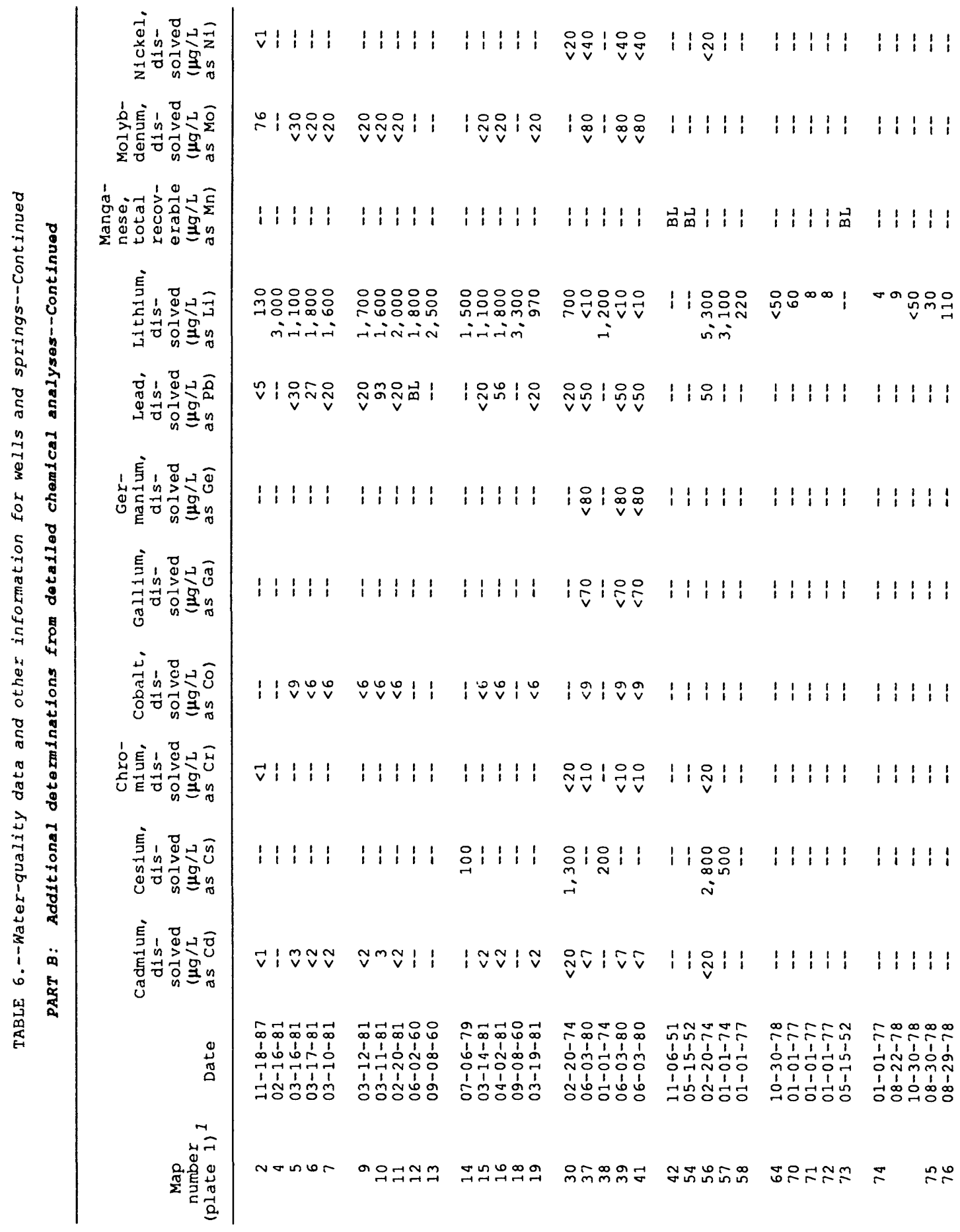




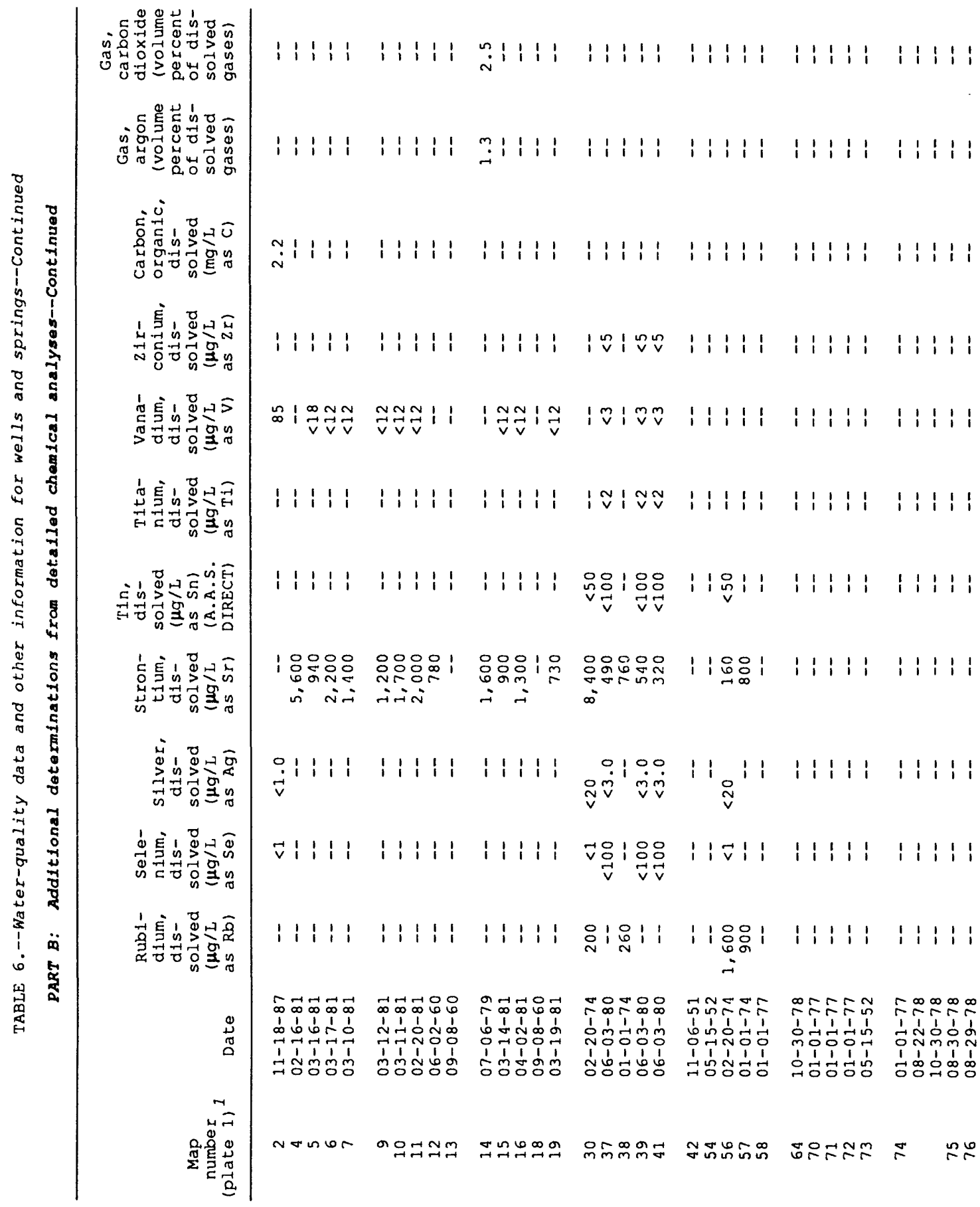




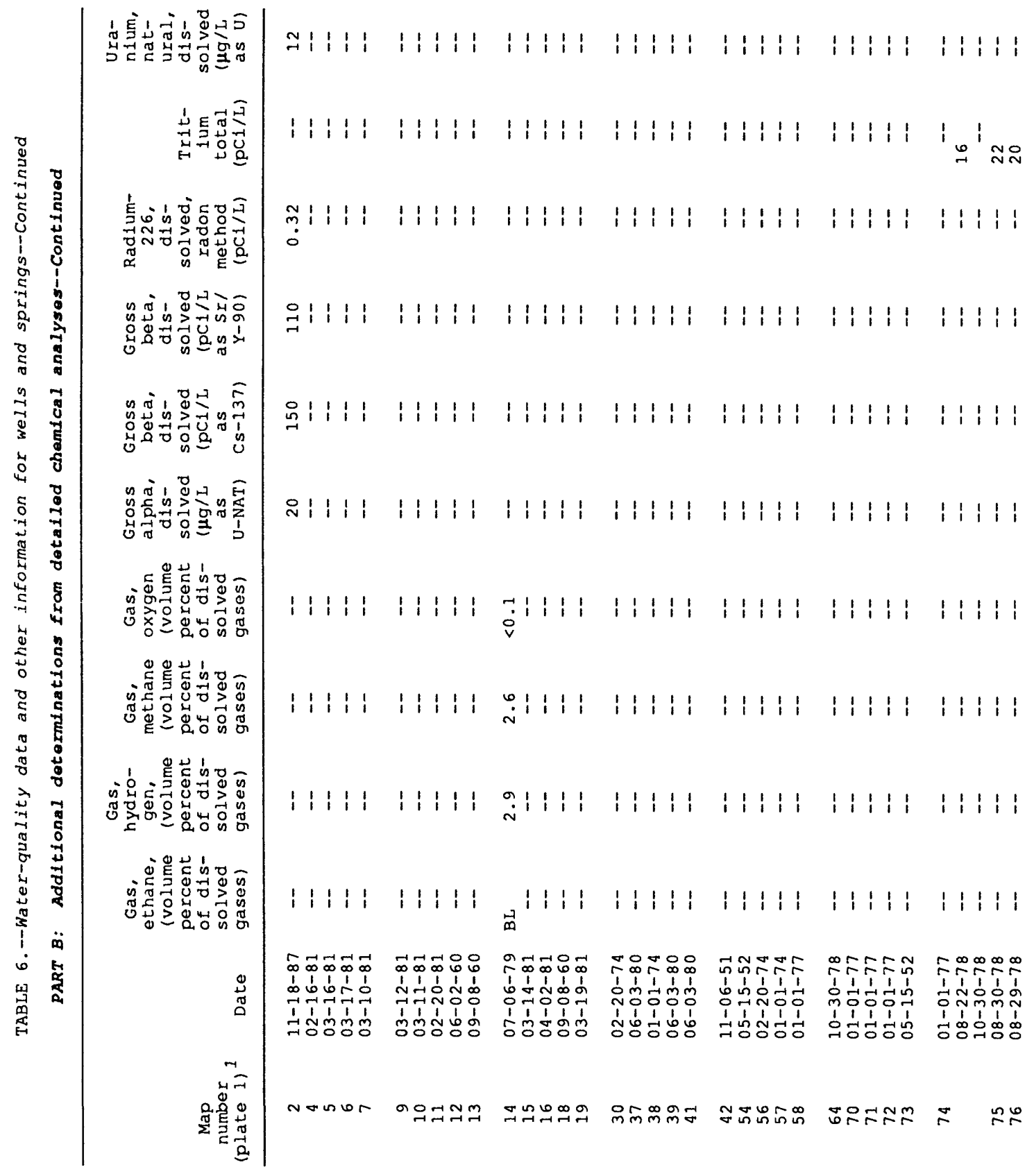




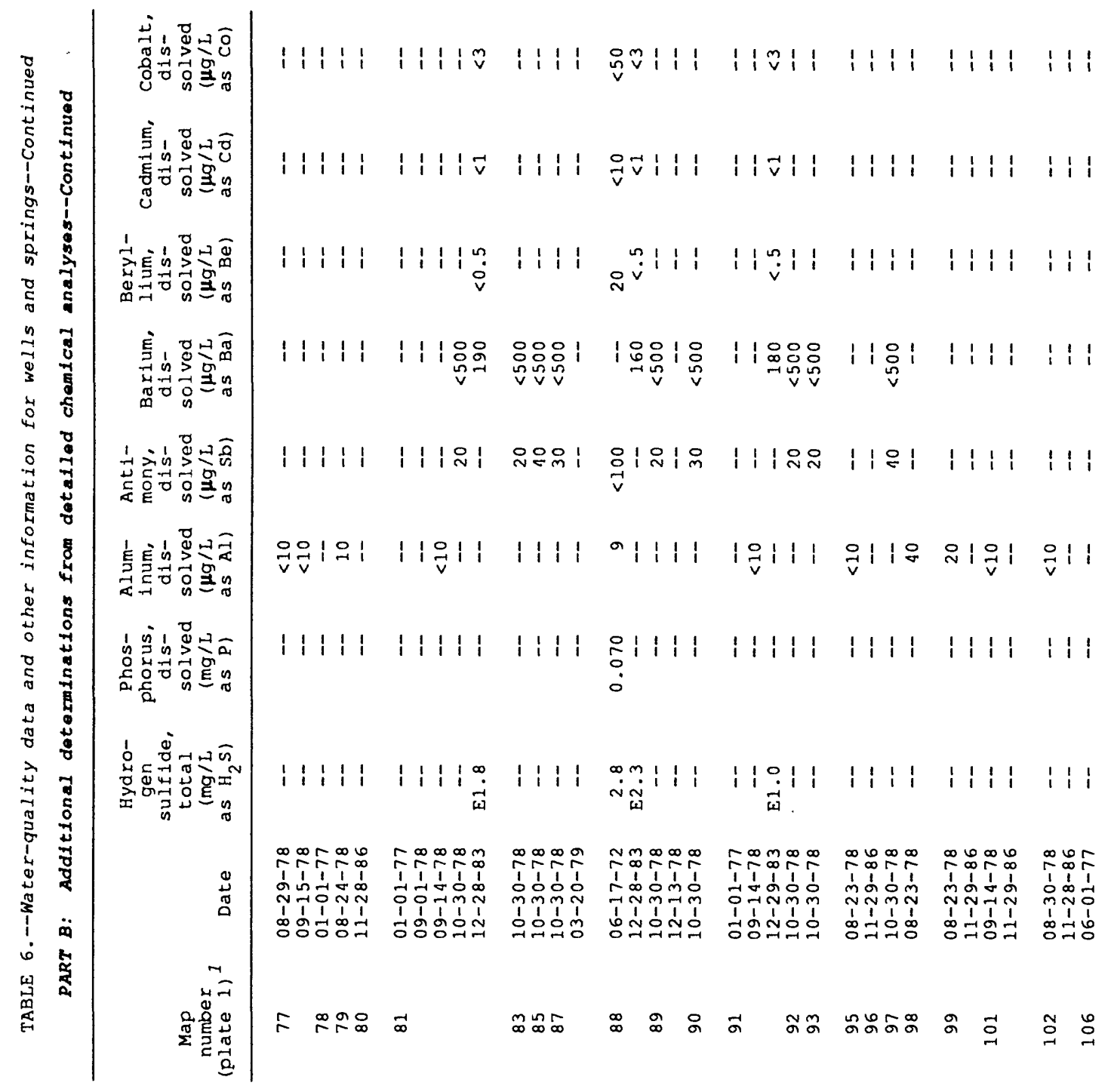




\begin{tabular}{|c|c|c|c|c|c|c|c|c|c|c|}
\hline & 至 & 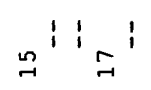 & $i i_{m} \mid i$ & $1: 111$ & $1:$ & $1: 1$ & ${ }_{\exists} \mid 11$ & $\sigma^{2} 11:$ & $\begin{array}{l}9 \\
2 \\
r\end{array}: 1$ & $1:$ \\
\hline & 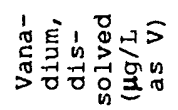 & 11111 & $1: 1: v$ & $1: 111$ & $i \stackrel{o}{v}$ & $1: 1$ & 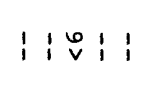 & $1: 11$ & $1: 1: 1$ & $1 i$ \\
\hline 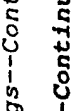 & 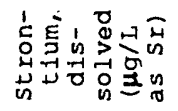 & $1: 111$ & 11118 & $1: 11$ & ని & $1: 1$ & | 180 & $1: 11$ & $1: 111$ & $1: 1$ \\
\hline ฐั่ & 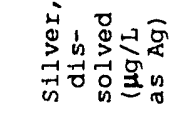 & 11111 & 11111 & $1: 11$ & $\stackrel{\sim}{V}^{1}$ & 111 & $11: 11$ & $1: 11$ & $1: 11$ & 111 \\
\hline 8 & 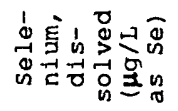 & $11: 11$ & $1: 1111$ & $1: 11$ & $\vec{v} 1$ & 111 & $1: 1111$ & 1111 & 1111 & 11 \\
\hline$\stackrel{7}{7}$ & 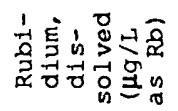 & $1: 111$ & 11111 & $1: 11$ & 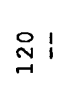 & 111 & 11111 & 1111 & $1: 11$ & 111 \\
\hline : & 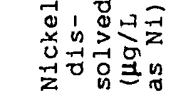 & $1: 11:$ & 111111 & $1: 111$ & 郘i & $1: 1$ & 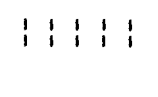 & $1: 11$ & $1: 1: 1$ & $1: 1$ \\
\hline$\frac{0}{3}$ & 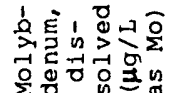 & 11111 & 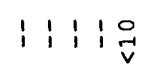 & 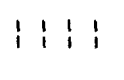 & $1 \stackrel{\circ}{v}$ & 111 & $i \mathfrak{i} i \mid$ & $1: 111$ & $1: 11$ & 111 \\
\hline 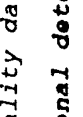 & 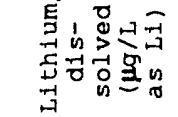 & 윳유 & 只: & 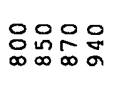 & $\begin{array}{l}0_{0}^{\infty} \\
a_{\pi}^{\infty}\end{array}$ & 숭요 & 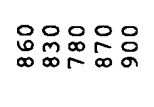 & 우 ${ }^{\infty}$ 요 & 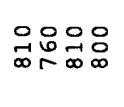 & $﹎{0}^{\infty}$ \\
\hline 苞 & 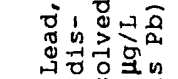 & $1: 111$ & 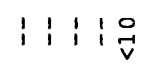 & $1: 11$ & $\stackrel{\circ}{\square} \vec{v}$ & $1: 1$ & $i \vdots \stackrel{0}{i} i$ & $1: 11$ & $1: 111$ & $1: 1$ \\
\hline 㭊 & & 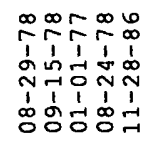 & 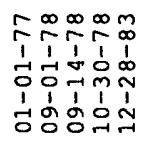 & 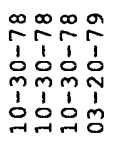 & 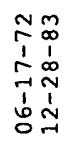 & 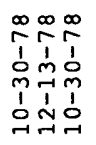 & 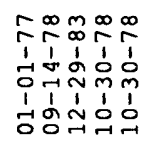 & $\begin{array}{l}0 \\
0 \\
0\end{array}$ & $\begin{array}{l}0 \\
0 \\
0\end{array}$ & 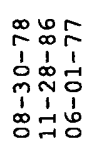 \\
\hline & 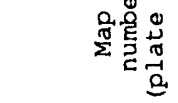 & $\hat{\sim} \stackrel{\infty}{\wedge} \underset{\Gamma}{ }$ & $\vec{\infty}$ & $\mathbb{\infty}_{\infty}^{\infty} \stackrel{\infty}{\infty}$ & $\underset{\infty}{\infty}$ & ஃ : & สูต & ถูรัด์ & & 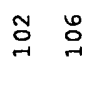 \\
\hline
\end{tabular}




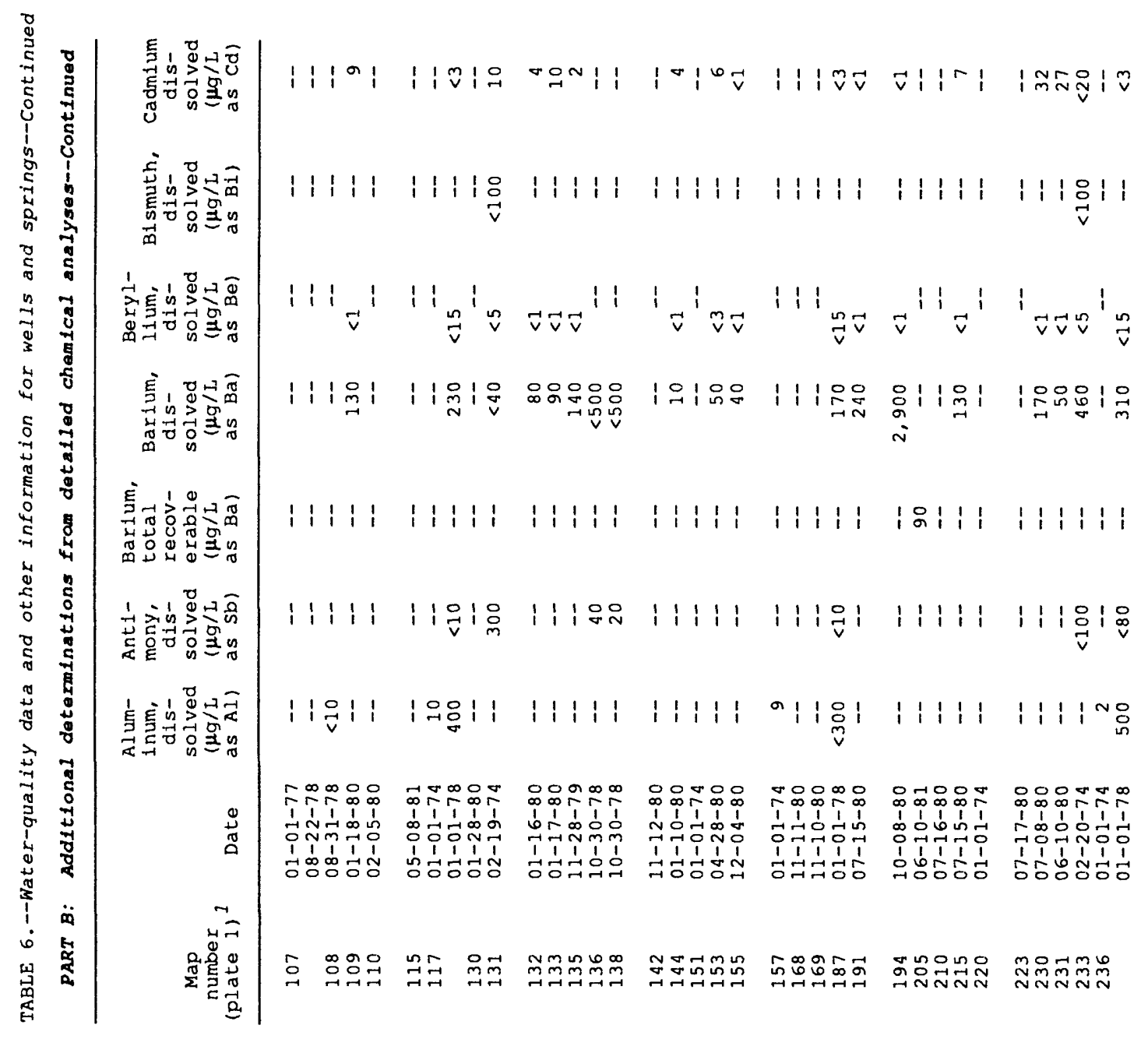




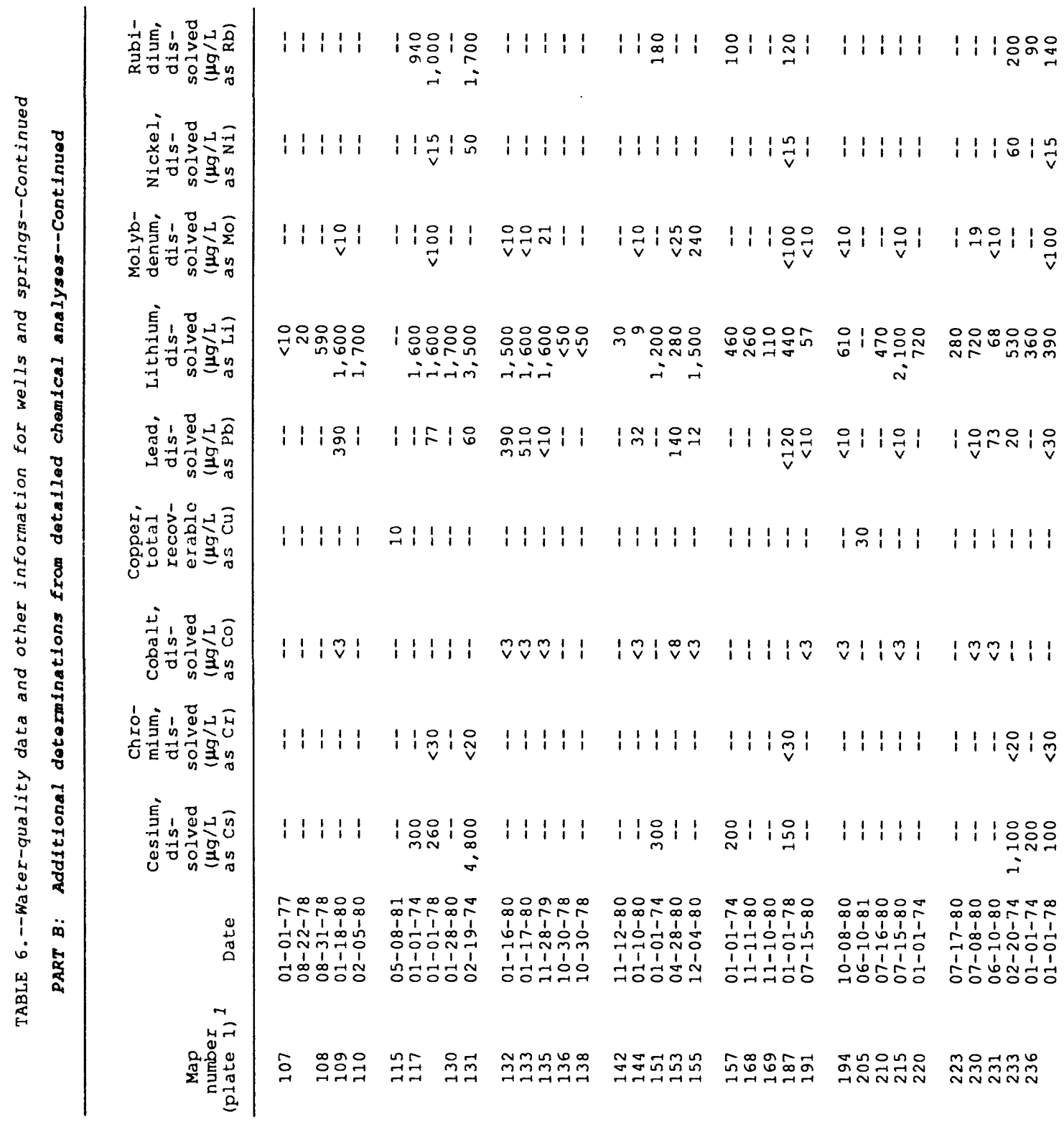




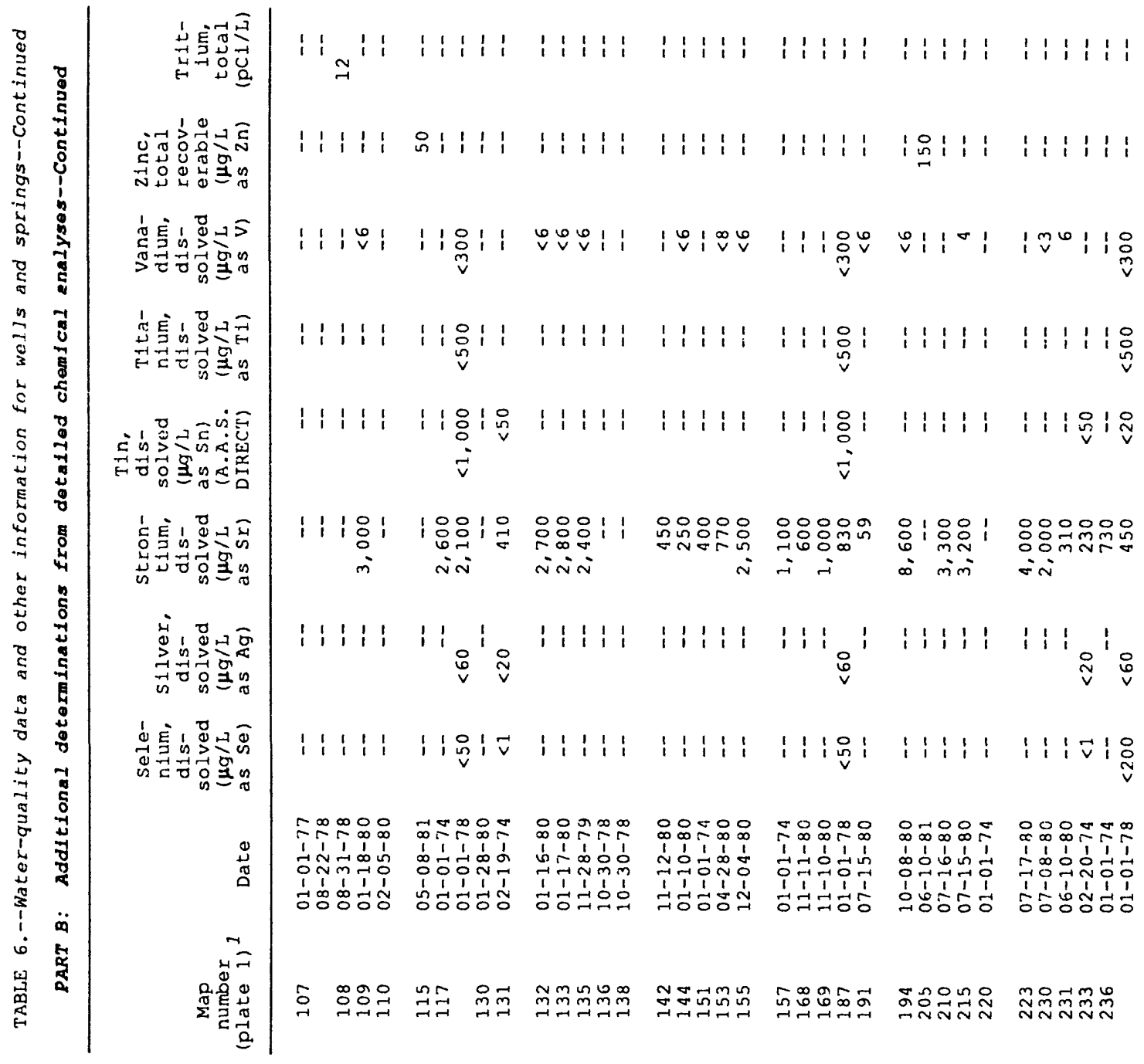




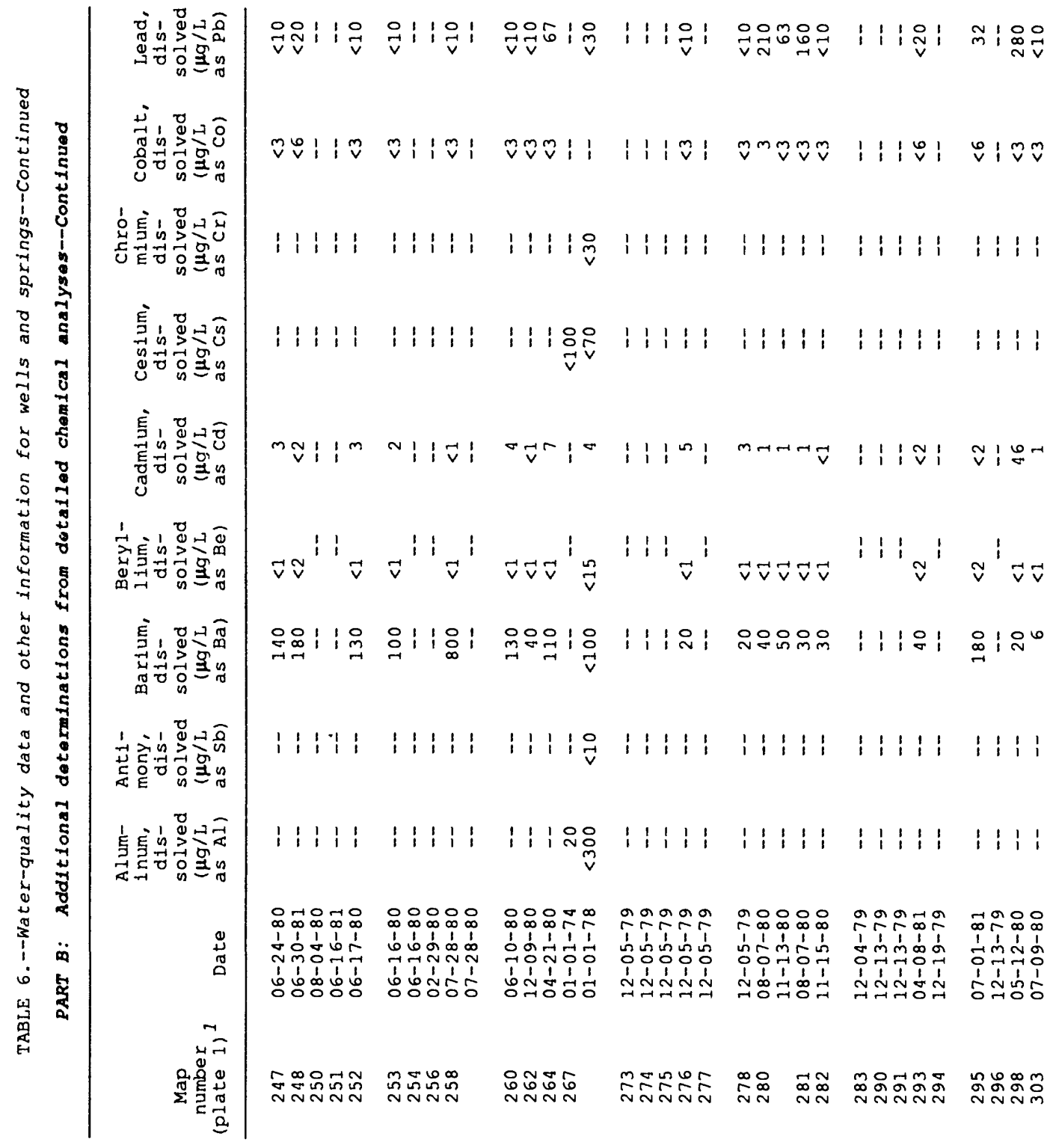




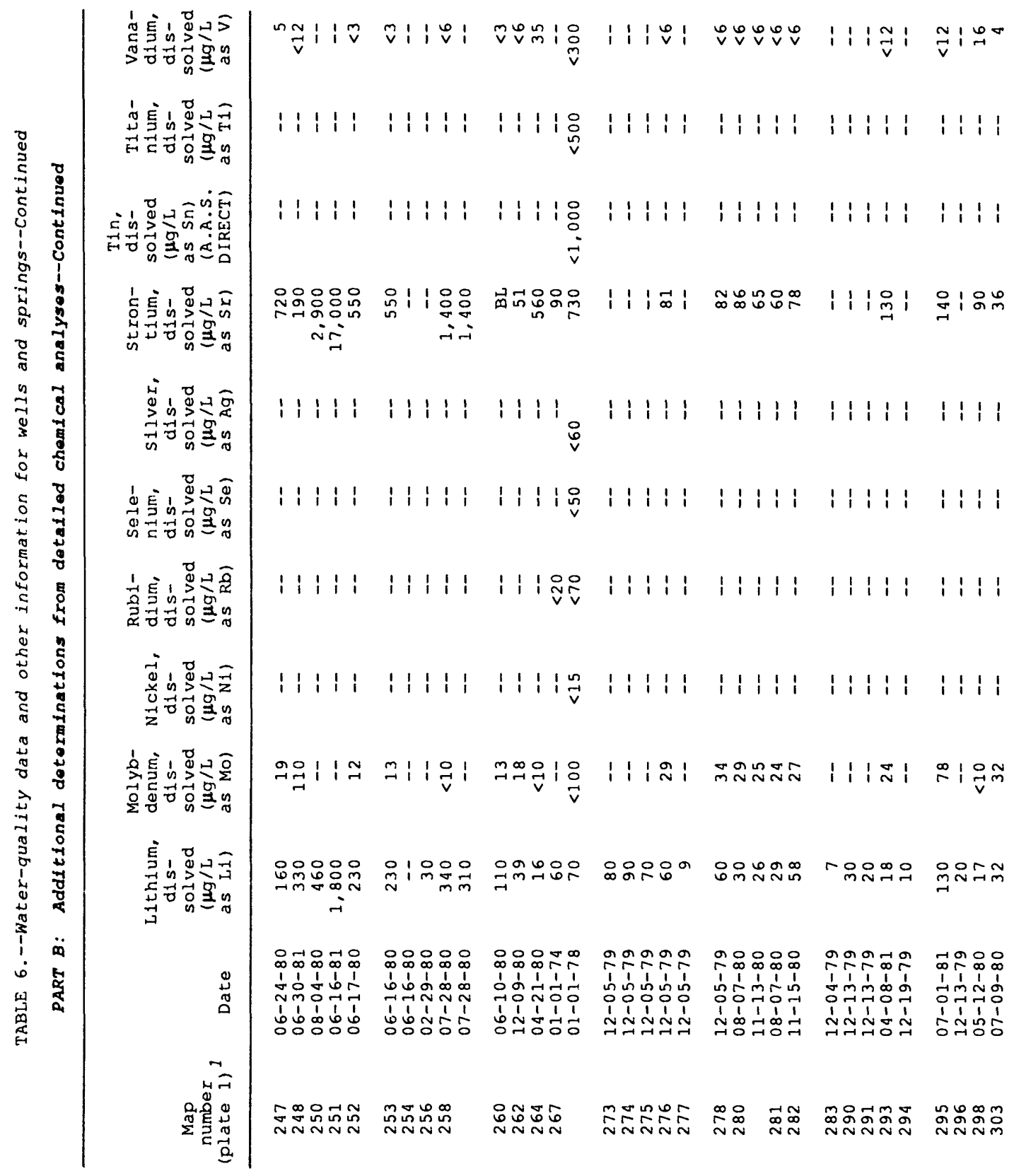




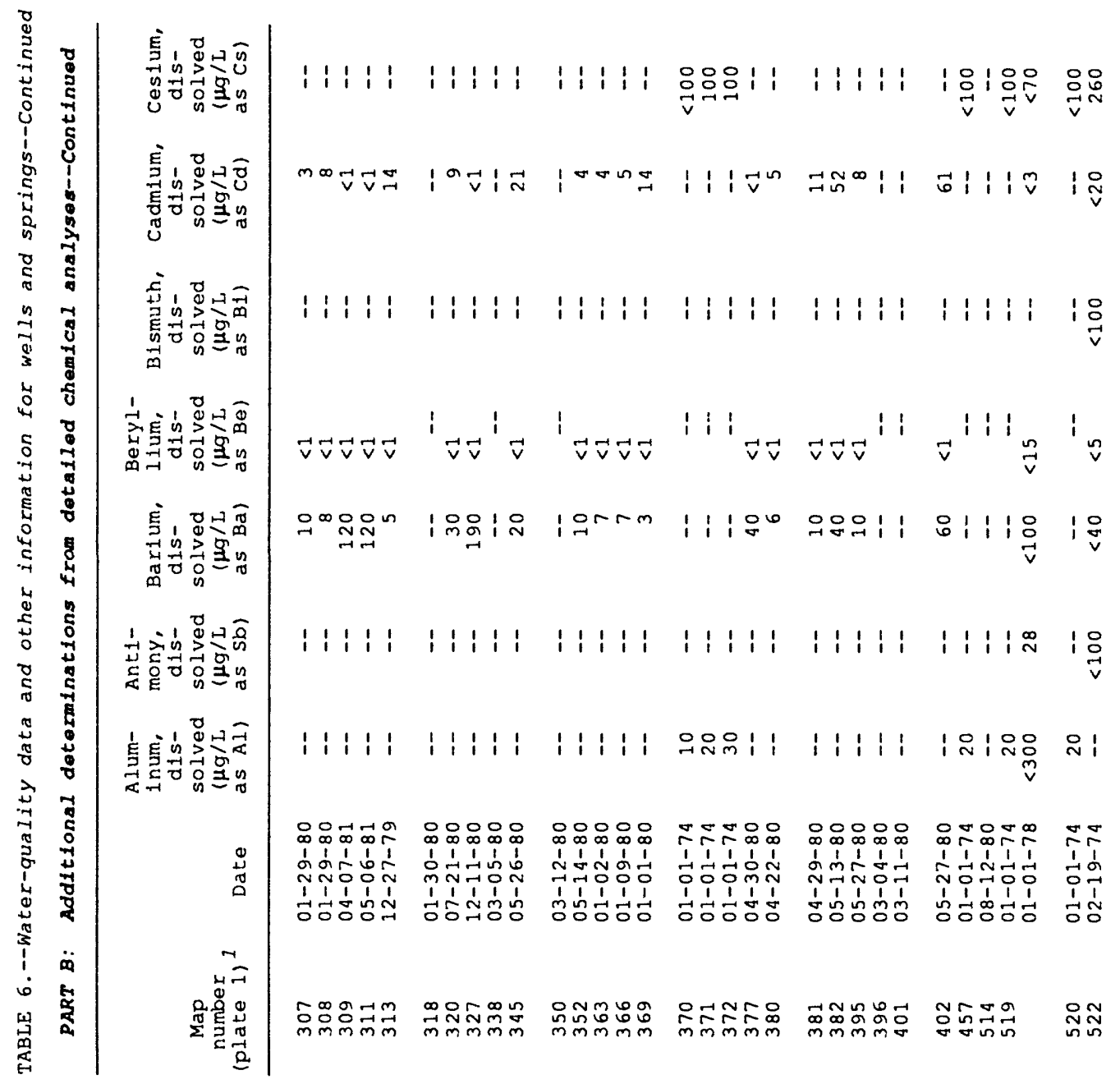




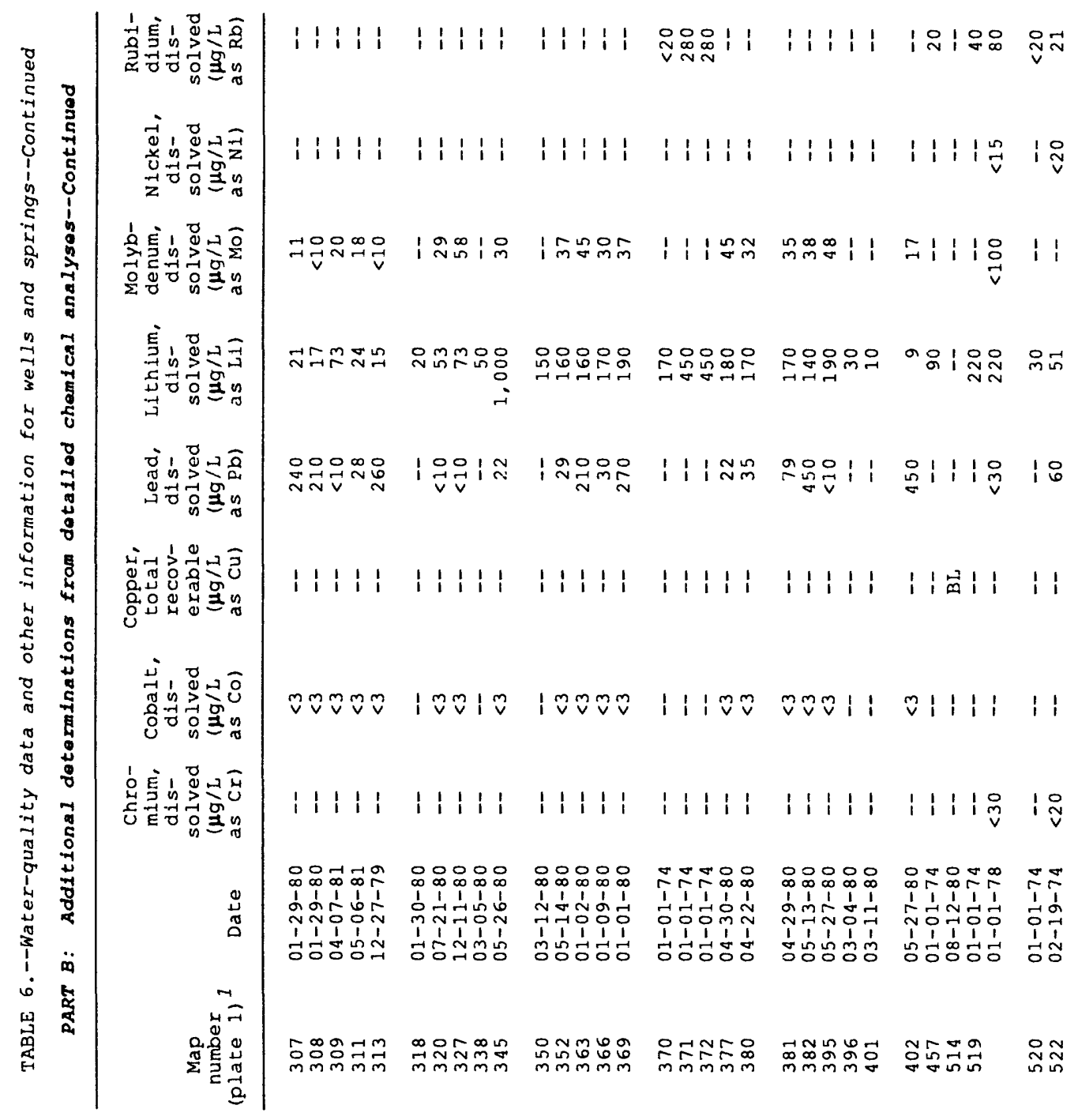




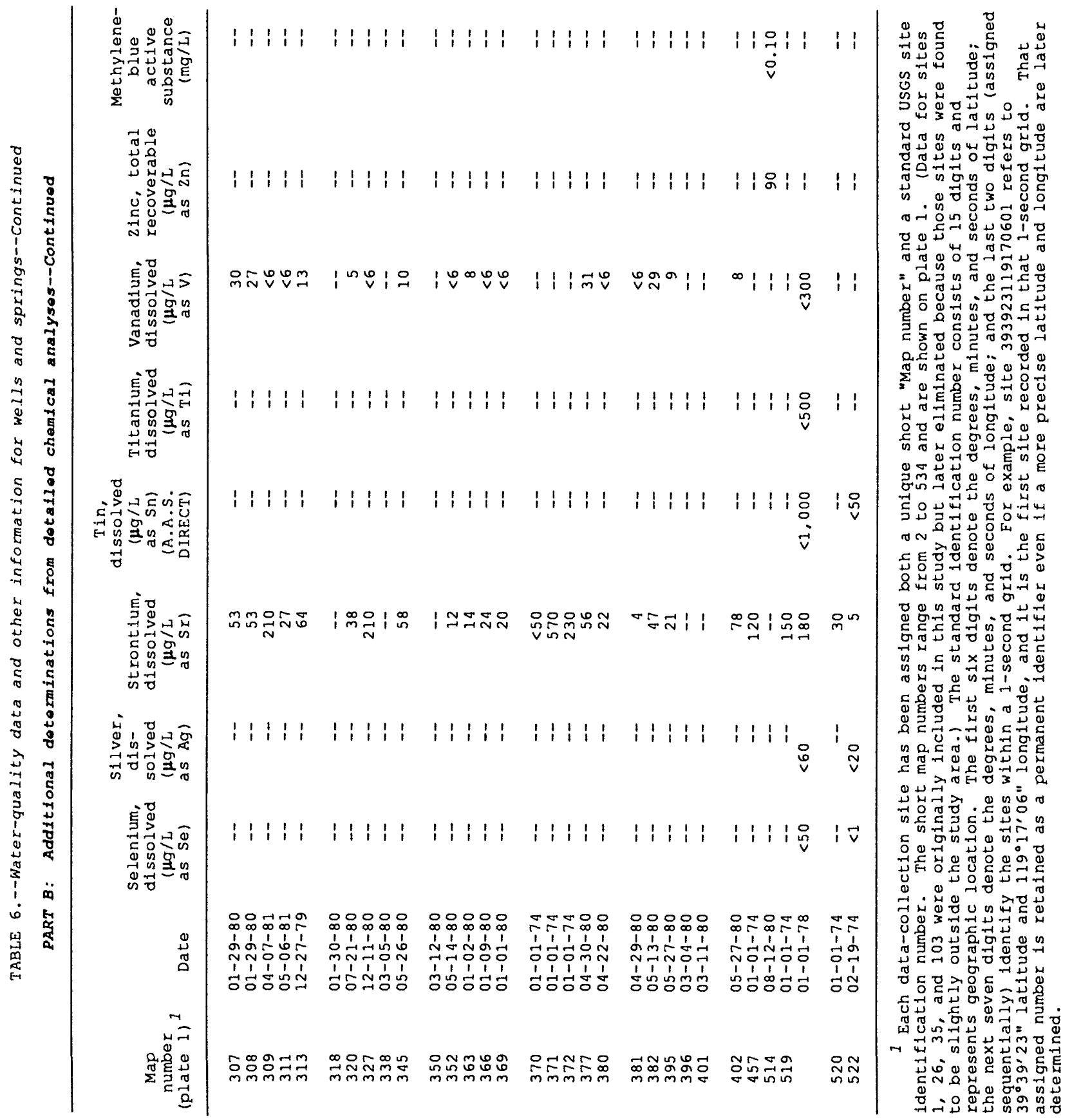


TABLE 7.--Maximum, minimum, and median values for selected constituents and properties of water from wells and springs

[Abbreviations and symbols: BL, below reporting limit for analytical procedure used; E, estimated; FET, fixed endpoint titration; fld, field; IT, incremental titration; lab, laboratory; $\mathrm{mg} / \mathrm{L}$, milligrams per liter; ${ }^{\circ} \mathrm{C}$, degrees Celsius; $\mu \mathrm{g} / \mathrm{L}$, micrograms per liter; $\mu \mathrm{S} / \mathrm{cm}$, microsiemens per centimeter at $25^{\circ} \mathrm{C}$

$<$, less than; -- not determined]

\begin{tabular}{|c|c|c|c|c|}
\hline $\begin{array}{l}\text { Number } \\
\text { of } \\
\text { determinations }\end{array}$ & Constituent & Maximum & Minimum & Median \\
\hline $\begin{array}{r}249 \\
190 \\
499 \\
21 \\
21 \\
515\end{array}$ & $\begin{array}{l}\text { Specific conductance, field ( } \mathrm{HS} / \mathrm{cm} \text { ) } \\
\text { pH, field (standard units) } \\
\left.\text { Water temperature ( }{ }^{\circ} \mathrm{C}\right) \\
\text { Color (platinum cobalt units) } \\
\text { Turbidity (Jackson turbidity units) } \\
\text { Hardness (mg/L as } \mathrm{CaCO}_{3} \text { ) }\end{array}$ & $\begin{array}{r}47,700 \\
11.7 \\
116.5 \\
40 \\
7 \\
2,300\end{array}$ & $\begin{array}{l}155 \\
4.7 \\
8.0 \\
2 \\
B L \\
B L\end{array}$ & $\begin{array}{r}810 \\
8.0 \\
20 \\
3 \\
1 \\
110\end{array}$ \\
\hline $\begin{array}{r}318 \\
21 \\
503 \\
21 \\
394 \\
14\end{array}$ & $\begin{array}{l}\text { Noncarbonate hardness (mg/L as } \mathrm{CaCO}_{3} \text { ) } \\
\text { Calcium, total (mg/L as Ca) } \\
\text { Calcium, dissolved (mg/L as Ca) } \\
\text { Magnesium, total (mg/L as Mg) } \\
\text { Magnesium, dissolved (mg/L as Mg) } \\
\text { Sodium, total (mg/L as Na) }\end{array}$ & $\begin{array}{r}1,700 \\
440 \\
500 \\
100 \\
480 \\
1,500\end{array}$ & $\stackrel{1}{B L}_{9}^{B L}$ & $\begin{array}{l}\text { BL } \\
45 \\
30 \\
11 \\
4.2 \\
21\end{array}$ \\
\hline $\begin{array}{l}383 \\
342 \\
124\end{array}$ & $\begin{array}{l}\text { Sodium, dissolved (mg/L as } \mathrm{Na} \text { ) } \\
\text { Sodium-adsorption ratio } \\
\text { Sodium + potassium, dissolved } \\
\quad(\mathrm{mg} / \mathrm{L} \text { as } \mathrm{Na} \text { ) }\end{array}$ & $\begin{array}{r}31,000 \\
4,000 \\
\end{array}$ & 10 & $\begin{array}{r}150 \\
11 \\
625\end{array}$ \\
\hline $\begin{array}{r}14 \\
378 \\
93\end{array}$ & $\begin{array}{l}\text { Potassium, total (mg/L as K) } \\
\text { Potassium, dissolved (mg/L as K) } \\
\text { Bicarbonate, whole water, FET, } \\
\text { fld (mg/L as } \mathrm{HCO}_{3} \text { ) }\end{array}$ & $\begin{array}{r}130 \\
230 \\
1,210\end{array}$ & BL & 200 \\
\hline $\begin{array}{r}116 \\
75\end{array}$ & $\begin{array}{l}\text { Bicarbonate, IT, fld (mg/L as } \mathrm{HCO}_{3} \text { ) } \\
\text { Carbonate, whole water, } \mathrm{EET} \text {, } \\
\quad \text { fld (mg/L as } \mathrm{CO}_{3} \text { ) }\end{array}$ & $\begin{array}{r}9,560 \\
86\end{array}$ & $\begin{array}{r}2 \\
B L\end{array}$ & 231 \\
\hline $\begin{array}{l}110 \\
117\end{array}$ & $\begin{array}{l}\text { Carbonate, IT, fld (mg/L as } \mathrm{CO}_{3} \text { } \\
\text { Alkalinity, whole water, } \mathrm{FET} \\
\quad\left(\mathrm{mg} / \mathrm{L} \text { as } \mathrm{CaCO}_{3}\right)\end{array}$ & $\begin{array}{l}902 \\
992\end{array}$ & $\begin{array}{r}\mathrm{BI} \\
2\end{array}$ & 2 \\
\hline $\begin{array}{l}39 \\
21\end{array}$ & $\begin{array}{l}\text { Sulfide, dissolved (mg/L as S) } \\
\text { sulfate, total (mg/L as } \mathrm{SO}_{4} \text { ) }\end{array}$ & $200^{2.1}$ & $\begin{array}{r}\text { BL } \\
4\end{array}$ & $\begin{array}{l}\text { BL } \\
56\end{array}$ \\
\hline $\begin{array}{l}493 \\
541\end{array}$ & $\begin{array}{l}\text { Sulfate, dissolved (mg/L as } \mathrm{SO}_{4} \text { ) } \\
\text { Chloride, dissolved } \\
\quad(\mathrm{mg} / \mathrm{L} \text { as Cl) }\end{array}$ & $\begin{array}{r}4,500 \\
44,000\end{array}$ & $\begin{array}{l}3 \\
4\end{array}$ & $\begin{array}{l}59 \\
48\end{array}$ \\
\hline $\begin{array}{r}20 \\
311 \\
29 \\
16\end{array}$ & $\begin{array}{l}\text { Eluoride, total (mg/L as F) } \\
\text { Fluoride, dissolved (mg/L as F) } \\
\text { Bromide, dissolved (mg/L as Br) } \\
\text { Iodide, dissolved (mg/L as I) }\end{array}$ & $\begin{array}{l}16^{4.8} \\
8 \\
.4\end{array}$ & $\begin{array}{l}B L^{-1} \\
B L \\
B L\end{array}$ & $\begin{array}{r}.2 \\
1.8 \\
.2 \\
.01\end{array}$ \\
\hline $\begin{array}{r}345 \\
67\end{array}$ & $\begin{array}{l}\left.\text { Silica, dissolved (mg/L as } \mathrm{SiO}_{2}\right) \\
\text { Solids, residue at } 180^{\circ} \mathrm{C} \text {, }\end{array}$ & 280 & .8 & 61 \\
\hline 28 & $\begin{array}{l}\text { dissolved }(\mathrm{mg} / \mathrm{L}) \\
\text { Residue at } 105{ }^{\circ} \mathrm{C} \text {, }\end{array}$ & 16,500 & 186 & 532 \\
\hline 363 & $\begin{array}{l}\text { dissolved (mg/L) } \\
\text { Solids, sum of constituents, } \\
\text { dissolved (mg/L) }\end{array}$ & $\begin{array}{l}17,000 \\
84,200\end{array}$ & 122 & 573 \\
\hline 36 & $\begin{array}{l}\text { Nitrogen nitrate, dissolved } \\
(\mathrm{mg} / \mathrm{L} \text { as } \mathrm{N})\end{array}$ & 1.5 & $\mathrm{BL}$ & .105 \\
\hline $\begin{array}{r}20 \\
135\end{array}$ & $\begin{array}{l}\left.\text { Nitrogen nitrate, total (mg/L as } \mathrm{NO}_{3}\right) \\
\text { Nitrogen nitrate, dissolved } \\
\left.\text { (mg/L as } \mathrm{NO}_{3}\right)\end{array}$ & 220 & $\mathrm{BL}$ & $\begin{array}{r}1.4 \\
.8\end{array}$ \\
\hline
\end{tabular}


TABLE 7.--Maximum, minimum, and median values for selected constituents and properties of water from wells and springs--Continued

\begin{tabular}{|c|c|c|c|c|}
\hline $\begin{array}{l}\text { Number } \\
\text { of } \\
\text { determinations }\end{array}$ & Constituent & Maximum & Minimum & Median \\
\hline 14 & $\begin{array}{l}\text { Nitrogen nitrite, dissolved } \\
\text { (mg/L as N) }\end{array}$ & 0.05 & BL & 0.01 \\
\hline $\begin{array}{r}12 \\
13 \\
8\end{array}$ & $\begin{array}{l}\text { Nitrogen nitrite + nitrate, } \\
\text { dissolved (mg/L as } N \text { ) } \\
\text { Nitrogen ammonia, total (mg/L as N) } \\
\text { Nitrogen ammonia, dissolved } \\
\quad \text { (mg/L as N) }\end{array}$ & $\begin{array}{r}.94 \\
.80 \\
1.0\end{array}$ & $\mathrm{BL}^{.01}$ & $\begin{array}{l}.105 \\
.40 \\
.45\end{array}$ \\
\hline $\begin{array}{l}19 \\
11\end{array}$ & $\begin{array}{l}\left.\text { Phosphorus, total (mg/L as } \mathrm{PO}_{4}\right) \\
\text { Phosphorus, dissolved } \\
\text { (mg/L as } \mathrm{PO}_{4} \text { ) }\end{array}$ & 2.0 & $\begin{array}{r}.02 \\
<.10\end{array}$ & $\begin{array}{l}.04 \\
.10\end{array}$ \\
\hline $\begin{array}{l}39 \\
28 \\
18 \\
56 \\
89 \\
75\end{array}$ & $\begin{array}{l}\text { Aluminum, dissolved ( } \mu \mathrm{g} / \mathrm{L} \text { as } \mathrm{Al}) \\
\text { Antimony, dissolved ( } \mathrm{g} / \mathrm{L} \text { as } \mathrm{Sb}) \\
\text { Arsenic, total (ug/L as As) } \\
\text { Arsenic, dissolved ( } \mu \mathrm{g} / \mathrm{L} \text { as } \mathrm{As}) \\
\text { Barium, dissolved ( } \mu \mathrm{g} / \mathrm{L} \text { as } \mathrm{Ba}) \\
\text { Beryllium, dissolved ( } \mu \mathrm{g} / \mathrm{L} \text { as } \mathrm{Be})\end{array}$ & $\begin{array}{r}520 \\
300 \\
110 \\
160 \\
2,900 \\
20\end{array}$ & $\begin{array}{l}\text { BL } \\
3 \\
B L \\
B L \\
3 \\
<.5\end{array}$ & $\begin{array}{r}10 \\
30 \\
5 \\
12 \\
100 \\
1\end{array}$ \\
\hline $\begin{array}{r}5 \\
299 \\
76 \\
25 \\
14 \\
65\end{array}$ & $\begin{array}{l}\text { Bismuth, dissolved ( } \mu \mathrm{g} / \mathrm{L} \text { as } \mathrm{Bi}) \\
\text { Boron, dissolved ( } \mathrm{g} / \mathrm{L} \text { as } \mathrm{B}) \\
\text { Cadmium, dissolved ( } \mu \mathrm{g} / \mathrm{L} \text { as } \mathrm{Cd}) \\
\text { Cesium, dissolved }(\mu \mathrm{g} / \mathrm{L} \text { as Cs) } \\
\text { Chromium, dissolved ( } \mu \mathrm{g} / \mathrm{L} \text { as Cr) } \\
\text { Cobalt, dissolved ( } \mathrm{g} / \mathrm{L} \text { as Co) }\end{array}$ & $\begin{array}{r}<100 \\
16,000 \\
61 \\
4,800 \\
-\frac{3}{3}\end{array}$ & $\begin{array}{r}<100 \\
B L \\
<1 \\
<70 \\
<1 \\
<3\end{array}$ & $\begin{array}{r}<100 \\
500 \\
3 \\
150 \\
20 \\
<3\end{array}$ \\
\hline $\begin{array}{r}91 \\
66 \\
123 \\
21 \\
77 \\
165\end{array}$ & $\begin{array}{l}\text { Copper, dissolved ( } \mu \mathrm{g} / \mathrm{L} \text { as } \mathrm{Cu}) \\
\text { Iron, total ( } \mu \mathrm{g} / \mathrm{L} \text { as Fe) } \\
\text { Iron, dissolved ( } \mathrm{gg} / \mathrm{L} \text { as } \mathrm{Fe}) \\
\text { Iron ( } \mu \mathrm{g} / \mathrm{L} \text { as } \mathrm{Fe}) \\
\text { Lead, dissolved ( } \mu \mathrm{g} / \mathrm{L} \text { as } \mathrm{Pb}) \\
\text { Lithium, dissolved ( } \mathrm{gg} / \mathrm{L} \text { as } \mathrm{Li})\end{array}$ & $\begin{array}{r}230 \\
2,400 \\
32,000 \\
730 \\
510 \\
5,300\end{array}$ & $\begin{array}{l}\text { BL } \\
B L \\
B L \\
B L \\
B I \\
4\end{array}$ & $\begin{array}{r}11 \\
20 \\
23 \\
50 \\
28 \\
220\end{array}$ \\
\hline $\begin{array}{r}132 \\
13 \\
100 \\
70 \\
15 \\
25\end{array}$ & $\begin{array}{l}\text { Manganese, dissolved (mg/L as } \mathrm{Mn}) \\
\text { Manganese ( } \mu \mathrm{g} / \mathrm{L} \text { as } \mathrm{Mn}) \\
\text { Mercury, dissolved ( } \mu \mathrm{g} / \mathrm{L} \text { as } \mathrm{Hg}) \\
\text { Molybdenum, dissolved ( } \mu \mathrm{g} / \mathrm{L} \text { as Mo) } \\
\text { Nickel, dissolved ( } \mathrm{g} / \mathrm{L} \text { as } \mathrm{Ni}) \\
\text { Rubidium, dissolved ( } \mathrm{g} / \mathrm{L} \text { as Rb) }\end{array}$ & $\begin{array}{r}1,000 \\
160 \\
4 \\
240 \\
60 \\
1,700\end{array}$ & $\begin{array}{r}\mathrm{BI}_{4} \\
\mathrm{BL} \\
\mathrm{BL} \\
<10 \\
<1 \\
<20\end{array}$ & $\begin{array}{l}19.5 \\
10 \\
20.2 \\
20.5 \\
20 \\
120\end{array}$ \\
\hline $\begin{array}{r}15 \\
15 \\
99 \\
13 \\
8 \\
70 \\
89\end{array}$ & 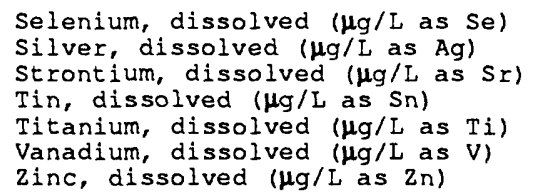 & $\begin{array}{r}-- \\
17,000 \\
-- \\
1,500\end{array}$ & $\begin{array}{l}<1 \\
<1 \\
B L \\
20 \\
<2 \\
<3 \\
B L\end{array}$ & $\begin{array}{r}<50 \\
<20 \\
400 \\
100 \\
<500 \\
6 \\
18\end{array}$ \\
\hline
\end{tabular}


TABLE 8.--Stable isotope data for selected wells and springs

(Symbol: --, not determined)

\begin{tabular}{|c|c|c|c|c|c|c|c|c|c|}
\hline $\begin{array}{c}\text { Map } \\
\text { number } \\
\text { (plate } 1, \\
\text { table } 6 \text { ) }\end{array}$ & Date & $\begin{array}{l}\text { Delta } \\
\text { carbon- } \\
13 \\
\text { (permil) }\end{array}$ & $\begin{array}{l}\text { Delta } \\
\text { deuter- } \\
\text { ium } \\
\text { (permil) }\end{array}$ & $\begin{array}{c}\text { Delta } \\
\text { oxygen- } \\
18 \\
\text { (permil) }\end{array}$ & $\begin{array}{c}\text { Map } \\
\text { number } \\
\text { (plate 1, } \\
\text { table 6) }\end{array}$ & Date & $\begin{array}{c}\text { Delta } \\
\text { carbon- } \\
13 \\
\text { (permil) }\end{array}$ & $\begin{array}{l}\text { Delta } \\
\text { deuter- } \\
\text { ium } \\
\text { (permil) }\end{array}$ & $\begin{array}{c}\text { Delta } \\
\text { oxygen- } \\
18 \\
\text { (permil) }\end{array}$ \\
\hline $\begin{array}{r}4 \\
5 \\
6 \\
7 \\
9 \\
10\end{array}$ & $\begin{array}{l}02-16-81 \\
03-16-81 \\
03-17-81 \\
03-10-81 \\
03-12-81 \\
03-11-81\end{array}$ & $\begin{array}{l}-- \\
-- \\
-- \\
-- \\
--\end{array}$ & $\begin{array}{l}-114.0 \\
-123.0 \\
-126.0 \\
-123.0 \\
-126.0 \\
-125.0\end{array}$ & $\begin{array}{l}-12.20 \\
-14.00 \\
-14.40 \\
-14.30 \\
-14.40 \\
-14.60\end{array}$ & $\begin{array}{l}168 \\
169 \\
191 \\
194 \\
209 \\
214\end{array}$ & $\begin{array}{l}11-11-80 \\
11-10-80 \\
07-15-80 \\
10-08-80 \\
07-16-80 \\
07-15-80\end{array}$ & $\begin{array}{l}-- \\
-- \\
-- \\
-- \\
--\end{array}$ & $\begin{array}{l}-89.5 \\
-82.0 \\
-98.5 \\
-86.0 \\
-78.5 \\
-80.5\end{array}$ & $\begin{array}{r}-7.80 \\
-6.20 \\
-10.80 \\
-8.40 \\
-6.80 \\
-2.50\end{array}$ \\
\hline $\begin{array}{l}11 \\
14 \\
15 \\
16 \\
19 \\
31\end{array}$ & $\begin{array}{l}02-20-81 \\
07-06-79 \\
03-14-81 \\
04-02-81 \\
03-19-81 \\
01-01-74\end{array}$ & $\begin{array}{l}-- \\
-- \\
-- \\
-- \\
-- \\
--\end{array}$ & $\begin{array}{l}-126.0 \\
-121.0 \\
-127.0 \\
-124.0 \\
-123.0 \\
-130.0\end{array}$ & $\begin{array}{l}-14.30 \\
-14.20 \\
-14.40 \\
-14.20 \\
-14.20 \\
-16.20\end{array}$ & $\begin{array}{l}223 \\
230 \\
231 \\
236 \\
247 \\
248\end{array}$ & $\begin{array}{l}07-17-80 \\
07-08-80 \\
06-10-80 \\
01-01-74 \\
06-24-80 \\
06-30-81\end{array}$ & $\begin{array}{r}-- \\
-- \\
-5 . \\
-5 \\
--\end{array}$ & $\begin{array}{l}-69.0 \\
-121.0 \\
-124.0 \\
-126.0 \\
-127.0 \\
-124.0\end{array}$ & $\begin{array}{l}-7.60 \\
-12.90 \\
-15.70 \\
-15.60 \\
-15.40 \\
-14.80\end{array}$ \\
\hline $\begin{array}{l}63 \\
70 \\
71 \\
72 \\
74\end{array}$ & $\begin{array}{l}04-23-81 \\
01-01-77 \\
01-01-77 \\
01-01-77 \\
01-01-77 \\
08-22-78\end{array}$ & $\begin{array}{l}-- \\
-- \\
-- \\
-- \\
--\end{array}$ & $\begin{array}{l}-121.0 \\
-124.0 \\
-122.0 \\
-122.0 \\
-124.0 \\
-124.0\end{array}$ & $\begin{array}{l}-15.70 \\
-15.80 \\
-16.00 \\
-15.90 \\
-16.40 \\
-15.80\end{array}$ & $\begin{array}{l}258 \\
260 \\
262 \\
264 \\
267 \\
280\end{array}$ & $\begin{array}{l}07-28-80 \\
06-10-80 \\
12-09-80 \\
04-21-80 \\
01-01-74 \\
08-07-80\end{array}$ & $\begin{array}{l}-- \\
-- \\
-- \\
-- \\
--\end{array}$ & $\begin{array}{l}-108.0 \\
-128.0 \\
-128.0 \\
-122.0 \\
-129.0 \\
-130.0\end{array}$ & $\begin{array}{l}-12.00 \\
-15.10 \\
-15.80 \\
-15.50 \\
-15.90 \\
-16.00\end{array}$ \\
\hline $\begin{array}{l}75 \\
76 \\
77 \\
78 \\
79 \\
80\end{array}$ & $\begin{array}{l}08-30-78 \\
08-29-78 \\
08-29-78 \\
01-01-77 \\
08-24-78 \\
11-28-86\end{array}$ & $\begin{array}{l}-- \\
-- \\
-- \\
-- \\
-- \\
--\end{array}$ & $\begin{array}{l}-124.0 \\
-129.0 \\
-133.0 \\
-124.0 \\
-125.0 \\
-131.5\end{array}$ & $\begin{array}{l}-16.40 \\
-16.10 \\
-16.80 \\
-15.10 \\
-16.90 \\
-16.35\end{array}$ & $\begin{array}{l}281 \\
283 \\
293 \\
295 \\
298\end{array}$ & $\begin{array}{l}11-13-80 \\
08-07-80 \\
12-04-79 \\
04-08-81 \\
07-01-81 \\
05-12-80\end{array}$ & $\begin{array}{l}-- \\
-- \\
-- \\
-- \\
--\end{array}$ & $\begin{array}{l}-129.0 \\
-130.0 \\
-122.0 \\
-127.0 \\
-129.0 \\
-120.0\end{array}$ & $\begin{array}{l}-16.00 \\
-16.40 \\
-15.80 \\
-15.40 \\
-15.40 \\
-15.40\end{array}$ \\
\hline $\begin{array}{l}89 \\
91 \\
\\
95 \\
96\end{array}$ & $\begin{array}{l}12-13-78 \\
01-01-77 \\
09-14-78 \\
12-29-83 \\
08-23-78 \\
11-29-86\end{array}$ & $\begin{array}{l}-- \\
-- \\
-- \\
-- \\
-- \\
--\end{array}$ & $\begin{array}{l}-124.0 \\
-131.0 \\
-131.0 \\
-129.0 \\
-125.0 \\
-131.0\end{array}$ & $\begin{array}{l}-14.00 \\
-16.40 \\
-16.90 \\
-16.30 \\
-16.60 \\
-16.35\end{array}$ & $\begin{array}{l}326 \\
327 \\
329 \\
332 \\
338 \\
339\end{array}$ & $\begin{array}{l}03-22-81 \\
12-11-80 \\
03-26-81 \\
08-22-79 \\
03-05-80 \\
08-22-79\end{array}$ & $\begin{array}{l}-- \\
-- \\
-- \\
-- \\
-- \\
--\end{array}$ & $\begin{array}{r}-112.0 \\
-86.0 \\
-124.0 \\
-127.0 \\
-115.0 \\
-118.0\end{array}$ & $\begin{array}{r}-14.10 \\
-6.70 \\
-16.00 \\
-16.70 \\
-14.90 \\
-15.10\end{array}$ \\
\hline $\begin{array}{r}98 \\
99 \\
101 \\
102\end{array}$ & $\begin{array}{l}08-23-78 \\
08-23-78 \\
11-29-86 \\
09-14-78 \\
11-29-86 \\
11-28-86\end{array}$ & $\begin{array}{l}-- \\
-- \\
-- \\
-- \\
-- \\
--\end{array}$ & $\begin{array}{l}-124.0 \\
-134.0 \\
-132.0 \\
-131.0 \\
-129.0 \\
-130.0\end{array}$ & $\begin{array}{l}-16.60 \\
-16.40 \\
-16.05 \\
-16.60 \\
-16.10 \\
-16.40\end{array}$ & $\begin{array}{l}341 \\
345 \\
352 \\
367 \\
370 \\
371\end{array}$ & $\begin{array}{l}04-09-81 \\
05-26-80 \\
05-14-80 \\
08-22-79 \\
01-01-74 \\
01-01-74\end{array}$ & $\begin{array}{l}-- \\
-- \\
-- \\
-- \\
--\end{array}$ & $\begin{array}{l}-130.0 \\
-128.0 \\
-131.0 \\
-124.0 \\
-130.0 \\
-129.0\end{array}$ & $\begin{array}{l}-16.70 \\
-16.00 \\
-16.60 \\
-16.10 \\
-16.60 \\
-14.50\end{array}$ \\
\hline $\begin{array}{l}104 \\
106 \\
107 \\
117 \\
132 \\
133\end{array}$ & $\begin{array}{l}11-29-86 \\
06-01-77 \\
01-01-77 \\
01-01-74 \\
01-16-80 \\
01-17-80\end{array}$ & $\begin{array}{r}-- \\
-- \\
-- \\
-13.40\end{array}$ & $\begin{array}{l}-130.0 \\
-124.0 \\
-125.0 \\
-101.0 \\
-99.0 \\
-98.0\end{array}$ & $\begin{array}{r}-16.20 \\
-- \\
- \\
-10.80 \\
-10.60 \\
-11.60\end{array}$ & $\begin{array}{l}372 \\
377 \\
380 \\
381 \\
382 \\
395\end{array}$ & $\begin{array}{l}01-01-74 \\
04-30-80 \\
04-22-80 \\
04-29-80 \\
05-13-80 \\
05-27-80\end{array}$ & $\begin{array}{l}-- \\
-- \\
-- \\
-- \\
--\end{array}$ & $\begin{array}{l}-128.0 \\
-129.0 \\
-131.0 \\
-131.0 \\
-125.0 \\
-131.0\end{array}$ & $\begin{array}{l}-14.10 \\
-16.30 \\
-16.70 \\
-16.40 \\
-16.40 \\
-16.60\end{array}$ \\
\hline $\begin{array}{l}142 \\
145 \\
151 \\
152 \\
153 \\
155 \\
156 \\
157\end{array}$ & $\begin{array}{l}11-12-80 \\
08-22-79 \\
01-01-74 \\
01-01-74 \\
04-28-80 \\
12-04-80 \\
08-22-79 \\
01-01-74\end{array}$ & $\begin{array}{l}-- \\
-- \\
-- \\
-- \\
-- \\
-- \\
-- \\
--\end{array}$ & $\begin{array}{r}-77.0 \\
-114.0 \\
-131.0 \\
-125.0 \\
-125.0 \\
-97.5 \\
-109.0 \\
-121.0\end{array}$ & $\begin{array}{r}-5.60 \\
-14.80 \\
-15.70 \\
-14.40 \\
-15.10 \\
-9.20 \\
-14.80 \\
-14.70\end{array}$ & $\begin{array}{l}402 \\
411 \\
457 \\
506 \\
518 \\
519 \\
520\end{array}$ & $\begin{array}{l}05-27-80 \\
01-01-74 \\
01-01-74 \\
01-01-74 \\
01-01-74 \\
01-01-74 \\
01-01-74\end{array}$ & $\begin{array}{l}-- \\
-- \\
-- \\
-- \\
-- \\
-- \\
--\end{array}$ & $\begin{array}{l}-115.0 \\
-135.0 \\
-128.0 \\
-127.0 \\
-125.0 \\
-126.0 \\
-124.0\end{array}$ & $\begin{array}{l}-14.50 \\
-16.40 \\
-16.30 \\
-16.20 \\
-15.30 \\
-15.60 \\
-15.30\end{array}$ \\
\hline
\end{tabular}

